\title{
BEWORTELINGSONDERZOEK EN ONDERGRONDBEWERKING IN DE NOORDOOSTPOLDER
}

WITH A SUMMARY

\author{
ROOTSTUDIES AND SUBSOILING IN I HE \\ NORTH-EASTERN POLDER
}

\section{PROEFSCHRIFT}

TER VERKRIJGING VAN DE GRAAD

VAN DOCTOR IN DE LANDBOUWKUNDE

OP GEZAG VAN DE REGTOR MAGNIFICUS IR. W. DE JONG

HOOGLERAAR IN DE VEETEELTWETENSGHAP,

TE VERDEDIGEN TEGEN DE BEDENKINGEN

VAN EEN COMMISSIE UIT DE SENAAT

DER LANDBOUWHOGESGHOOL TE WAGENINGEN

OP VRIJDAG 27 JUNI I958 TE 16 UUR

DOOR

J. J. JONKER

W. E. J. TJEENK WILLINK N.V., ZWOLLE, 1958

NNQ8201,245 


\title{
BEWORTELINGSONDERZOEK EN ONDERGRONDBEWERKING IN DE NOORDOOSTPOLDER
}

\author{
WITH A SUMMARY \\ ROOTSTUDIES AND SUBSOILING IN THE \\ NORTH-EASTERN POLDER \\ PROEFSCHRIFT \\ TER VERKRIJGING VAN DE GRAAD \\ VAN DOGTOR IN DE LANDBOUWKUNDE \\ OP GEZAG VAN DE RECTOR MAGNIFICUS IR. W. DE JONG, \\ HOOGLERAAR IN DE VEETEELTWETENSGHAP, \\ TE VERDEDIGEN TEGEN DE BEDENKINGEN \\ VAN EEN GOMMISSIE UIT DE SENAAT \\ DER LANDBOUWHOGESGHOOL TE WAGENINGEN \\ OP VRIJDAG 27 JUNI 1958 TE 16 UUR \\ DOOR \\ J. J. JONKER
}

W. E.J. Tjeenk Willink N.V., Zwolle 1958 


\section{STELLIN G E N}

1

De wortelhoeveelheden, verkregen uit met grondboren genomen grondmonsters van de bouwvoor en de ondergrond, geven geen juist beeld van de verdeling der wortels over een profiel.

Dit proefschrift I.

2

Het begrip „werkzame worteldiepte" geeft een onjuiste indruk van de betekenis van het gehele wortelstelsel.

M. A. J. Goedewaagen. Het worteIstelsel der. landbouwgewassen. 1942, p. 53.

3

Het maken van polyploïde rassen van graslandplanten heeft voor het Nederlandse grasland geen praktische betekenis.

4

Ofschoon een hoge „wortelwaarde" op grote wortelactiviteit kan duiden, moet toch bij de veredeling van landbouwgewassen de voorkeur worden gegeven aan planten die een uitgebreid wortelstelsel vormen.

A. E. H. R. Boonstra. Het begrip ,wortelwaarde". In: De plantenwortel in de landbouw. 1955. p. 107-118.

5

In grasmengsels, bestemd voor de inzaai van weiland, dienen ook zeer vroege hooitypen van Engels raaigras te worden opgenomen.

6

Het geven van zware stikstofbemestingen op klaverrijk jong grasland is niet noodzakelijk voor het verkrijgen van hoge opbrengsten.

7

Prummel's weerlegging van De. WIT's theorie over het verband tussen de gegeven en opgenomen hoeveelheid meststof bij verschillende manieren van toediening, is onvoldoende.

c. T. de Wit - Proefschrift Wageningen.

J. Prummel - Plant and Soil VIII (1957) : 231-253.

8

Een diepe ondergrondbewerking kan niet door de verbouw van luzerne worden vervangen.

De geschiktheid voor inpoldering van lichte mariene gronden hangt voornamelijk af van de vochtvoorziening der op deze gronden te telen gewassen. $\mathrm{Bij}$ de beoordeling van deze vochtvoorziening dient in de eerste plaats te worden gelet op de doorwortelbaarheid van de betreffende gronden. 
Volgens een goede gewoonte, mak ik van het verschijnen van dit proefschrift gaarne gebruik om alle hoogleraren, docenten en medewerkers van de Landbouwhogeschool, die aan mijn wetenschappelijke vorming hebben bijgedragen, mijn dank te betuigen.

Hooggeleerde DEwEz, naar U gaat mijn bijzondere dank uit voor de zorg en kritische zin waarmee $U$ dit resultaat van een veeljarig onderzoek hebt willen bestuderen, en voor de stimulans die $U$ mij hebt gegeven om door literatuurstudie het geheel af te ronden.

Veel ben ik verschuldigd aan de vroegere collega's van het voormalige C. I. L. O. Op de afdeling Weide- en Voederbouw werd mijn blijvende belangstelling voor graslandproblemen gewekt. Het werken in instituutsverband schonk tevens de gelegenheid om met de akkerbouw in contact te blijven.

De Directie van de Wieringermeer ben ik zeer erkentelijk voor de geboden gelegenheid om dit proefschrift tot stand te doen komen.

Onder Uw leiding, hooggeachte Bosma, leerde ik de problemen van de landbouw in de IJsselmeerpolders kennen. Van $U w$ wijze van probleemstelling en benadering van de oplossing ervan heb ik zeer veel geleerd. Voor uw grote belangstelling voor mijn bewortelingsonderzoek en de daarbij ondervonden steun, ben ik $U$ zeer dankbaar.

Beste Kluitenberg, je kennis van de polderbodem en belangstelling voor bewortelingsproblemen hebben veel bijgedragen aan dit onderzoek. Nog steeds denk ik met genoegen aan de tijd dat je in de Noordoostpolder werkte.

Waarde Geertsema, ofschoon een nauwgezette verzorging van de proefvelden en grote oplettendheid bij het nemen en verwerken van wortelmonsters voor $U$ en $U w$ medewerkers vanzelfsprekend is, wil ik die toch met dankbaarheid noemen.

Tenslotte dank ik alle collega's en medewerkers van de Directie van de Wieringermeer voor de ondervonden hulp bij het vervaardigen van worteldoorsneden, foto's en tekeningen en de zorg besteed aan manuscript en lay-out. 


\section{INHOUD}

INLEIDING

I. WIJZE VAN ONDERZOEK EN ENKELE RESULtateN • • • • • 6 Grondkolommen - • • . . • . • . • • • 6 Boormonsters . . . . . . . . . . . . . . . Naaldenplanken . Onderzoek naar foutenbronnen bij het spoelen en bewaren . 8 Horizontale verdeling van de wortels in de grond . . . . 10

II. DE ONTWIKKELING VAN HET WORTELSTELSEL IN EEN HOMOGEEN ZAVELPROFIEL . . . . . . . . . . . . . . 18

Granen . . . . . . . . . . . . . . 19

Wintertarwe . . . . . . . . . . . . $\quad .20$

Winterrogge . . . . . . . . . . . . . 34

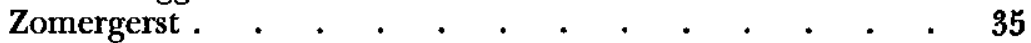

Haver . . . . . . . . . . . . . . 37

Zomertarwe . . . . . . . . . . . . . 37

Samenvatting • • • • • • • • • • • • c . .

Tweezaadlobbige landbouwgewassen . . . . . . . . . .

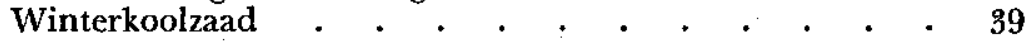

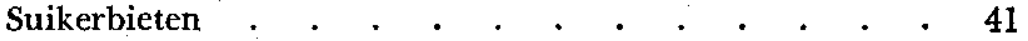

Groene erwten, capucijners en rozijnerwten . . . . 43

Vlas . . . . . . . . . . . . . . . 44

Luzerne . . . . . . . . . . . . . . 44

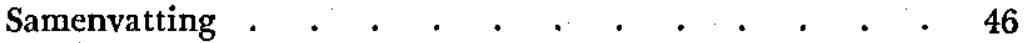

III. DE ONTWIKKELING VAN HET WORTELSTELSEL IN VERSCHILLENDE GRONDSOORTEN .

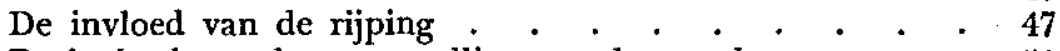

De invloed van de samenstelling van de grond . . . $\quad . \quad 50$

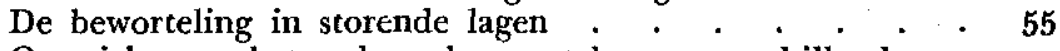

Overzicht van het gedrag der wortels van verschillende ge-

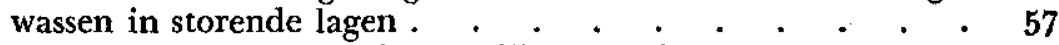

Een beschouwing over de mogelijke oorzaken van beperkte of ontbrekende wortelgroei . 
De betekenis van het wortelbeeld voor de opbrengst der gewassen . . . . . . . . . . . . . . 66

IV. DE BEWORTELING IN VERSCHILLENDE BODEMPROFIELEN . . . 68

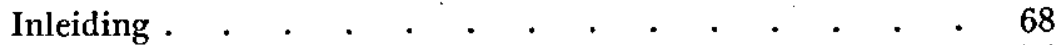

Het profiel type zwaar op zwaar $\quad . \quad$. . . . . . . . . . 74

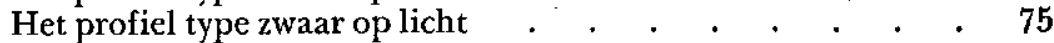

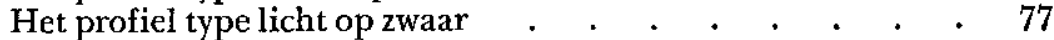

Het profiel type licht op licht (zavel) . . . . . . . . . . 78

Het profiel type licht op licht (zand) . . . . . . . . . . . 80

Het profiel type, waarin veen of detritus voorkomt $\quad . \quad$. $\quad . \quad 81$

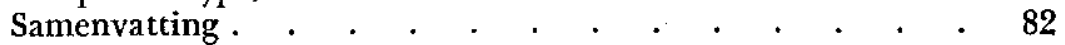

V. DE ONDERGRONDBEWERKINGSPROEFVELDEN . . . . . . . 84

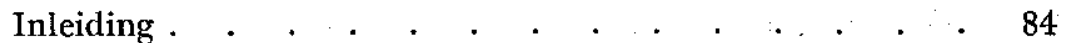

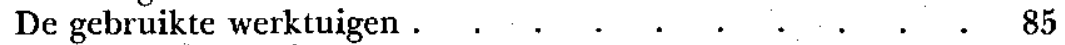

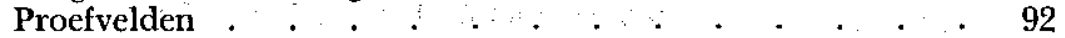

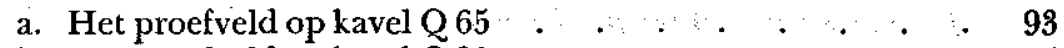

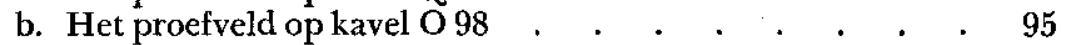

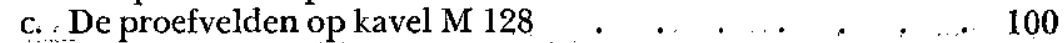

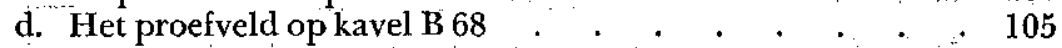

e. Het proefveld op kavel C62 62 . . . . . . . . .

f. Het proefveld op kavel D $24 \ldots \ldots$

Beschouwing over de ondergrondbewerkingsproefvelden . . 130

Samenvatting. . . . . . . . . . . . 133

VI. DE PRARTIJK DER ONDERGRONDBEWERKING IN DE NOORDOOSTPOLDER 135

Inleiding . . . . . . . . . . . . . . . . . 135

Overzicht van de afzettingen, welke dienden te worden losgemaakt . . . . . . . . . . . . . . 136

Het plan voor de ondergrondbewerking . $\quad$. . . . . . . . . .

$\therefore$ De bestendigheid van de losgemaakte structuren . . . . 141

SAMENVATting . . . . . . . . . . . .

SUMMARY . . . . . . . . . . . . . . . 152

EXPLANATION OF TERMS .

BETEKENIS VAN GEBRUIKTE SYMBOLEN VOOR GRONDSOORTEN IN DE NOORDOOSTPOLDER . . . . . . . . . . . . . . . . . . .

LiteratuUr . . . . . . . . . . . . . . . . 162

Foto-biJLAGEN . . . . . . . . . . . . . . . . . . 


\section{INLEIDING}

In 1942 viel de Noordoostpolder droog. De bodem was nog met water verzadigd, anaëroob en slechts geschikt voor planten die met hun wortels in een zuurstofvrij milieu kunnen leven.

Op het ogenblik van het droogvallen begon het rijpingsproces. Hieronder verstaat met het geheel van chemische, physische en biologische processen waardoor de bodem geschikt wordt voor de groei van landplanten. Uiterlijk wordt dit proces gekenmerkt door het gedeeltelijk verdwijnen van het water, voornamelijk door verdamping. Toetreding van lucht in de bodem wordt dan mogelijk, waarbij de aanvankelijk blauwzwarte kleur van de bodem verandert in grijs of bruin. ZuuR, Domingo en VAN Schreven geven een overzicht van deze rijping.

Gleveringa onderzocht de beworteling van de natuurlijke vegetatie en de landbouwgewassen in de tijd waarin de rijping was begonnen, maar nog niet tot grotere diepte was gevorderd. Hij nam waar, dat de bewortelingsdiepte in de eerste plaats werd bepaald door de grens van de rijping van de grond, en verder dat de grondsoort eveneens invloed had op de beworteling, hetzij door de mate van rijping, hetzij door de samenstelling. Zand werd minder goed doorworteld dan zavel. Naarmate de rijping voortschreed, werd de grond beter geschikt voor de groei van planten die voor de ontwikkeling en activiteit van hun wortels bepaalde eisen aan de zuurstofvoorziening stellen.

Toch werden op een gerijpte laag van ongeveer $20 \mathrm{~cm}$ dikte gewassen geteeld met zeer goede opbrengsten. Het aanvankelijk nog hoge vochtgehalte van de grond maakte het waarschijnlijk mogelijk, dat de watervoorziening van de planten uit een dergelijk dunne laag geen moeilijkheden ondervond (GoEdewaAGEN, 1955 b).

$\mathrm{Bij}$ het vorderen van de indroging in de diepte, gepaard gaande met een verdere rijping van de grond, wordt de opbouw van het profiel waaruit de planten vocht en voedsel moeten betrekken, steeds belangrijker. Door onderzoek van de beworteling kan worden nagegaan, in hoeverre de profielopbouw gunstig of ongunstig is voor de plantenwortels.

In 1946 was een klein gedeelte van de Noordoostpolder gedraineerd, het overige was toen slechts begreppeld of nog van geen enkele ontwateringsmogelijkheid voorzien. De daarmee samengaande grote versichillen in rijping en de aanwezigheid van sterk uiteenlopende profielen boden gelegenheid om de invloed van de rijping en de profielopbouw op de wortelontwikkeling na te gaan. 
Het onderzoeken en beschrijven van de beworteling onder uiteenlopende omstandigheden is op zichzelf zeer belangwekkend. Verschillende onderzoekers, die zich met wortelstudies bezighielden, hebben echter steeds de toepassing van de verkregen resultaten als doel gesteld. Deze toepassing kan o.a. van belang zijn voor de grondbewerking (CLEvERINGa, 1955), de bemesting (Prummel, De Wit), de ecologie (Goedewaagen, 1942, Weaver, Pavlychenko 1937 ), en de plantenverdeling (Boonstra).

Als doel van het bewortelingsonderzoek in de Noordoostpolder gold het beantwoorden van de vraag of er bodemlagen of profielen zijn die de ontwikkeling van de voor een goed gewas vereiste beworteling belemmeren en het aangeven van middelen om deze beworteling te verbeteren.

In de nu volgende verhandeling worden de verschillende facetten van het bewortelingsonderzoek en de daaruit voortvloeiende nodig geachte ondergrondbewerking behandeld.

In hoofdstuk I wordt een overzicht gegeven van de verschillende technieken die voor kwalitatief en kwantitatief onderzoek worden gebruikt. Voor een juist inzicht in de kwantitatieve bepaling van de wortels is de verdeling in de bouwvoor van de wortels van wintertarwe in dit hoofdstuk behandeld.

Om te kunnen beoordelen of het wortelstelsel van een gewas in zijn ontwikkeling wordt belemmerd, moet de normale ontwikkeling bekend zijn. Uit literatuurgegevens is wel bekend, dat de door de meeste gewassen bereikbare diepte varieert tussen 100 à $150 \mathrm{~cm}$ als minimum en 200 à $400 \mathrm{~cm}$ als maximum. In de Noordoostpolder wordt slechts zelden een grotere diepte dan $125 \mathrm{~cm}$ bereikt, zodat hieruit de gevolgtrekking zou kunnen worden gemaakt, dat de gesteldheid van de bodem van de polder onvoldoende mogelijkheden voor de maximale wortelontwikkeling biedt en dientengevolge ook minder gunstig zou zijn voor de verbouw van landbouwgewassen. Tegenover deze opvatting kan de mening van VELDMAN worden gesteld, dat een zavelprofiel van minstens $70 \mathrm{~cm}$ diepte voldoende is voor de verbouw van landbouwgewassen.

Als criterium voor de beoordeling van de beworteling werd de beworteling in een homogeen zavelprofiel van $100 \mathrm{~cm}$ diepte genomen.

In hoofdstuk II wordt de ontwikkeling van de beworteling van de belangrijkste landbouwgewassen beschreven en wel van kieming tot rijpheid. Van de wintertarwe is de kwantitatieve ontwikkeling eveneens behandeld. KöNExaMr geeft reeds aan, dat het voor het onderzoek naar de bij de oogst in de grond achterblijvende delen van belang is om de ontwikkeling gedurende de gehele groeiperiode te onderzoeken.

In hoofdstuk III wordt het gedrag van de wortels in de verschillende geologische afzettingen in de Noordoostpolder behandeld. Indien de invloed van bepaalde lagen op de beworteling bekend is en tevens de methode om de beworteling te verbeteren, kan aan de hand van de bodemkundige kaart worden aangegeven, waar en hoe bepaalde maatregelen met dit doel dienen te worden genomen.

In dit hoofdstuk komt tot uiting, dat het onderzoek (zoals vele land- 
bouwkundige onderzoekingen) een sterk proefondervindelijk karakter draagt. Vooral het visuele beeld van bodem en beworteling bepaalt de te volgen gedragslijn bij de verbetering van de profielen (hootdstukken $V$ en VI). Een algehele verklaring van de gevonden verschijnselen is nog niet gevonden; slechts ten aanzien van enkele problemen werden veronderstellingen gemaakt.

Tot besluit van het bewortelingsonderzoek wordt in hoofdstuk IV een beschrijving gegeven van de beworteling in de verschillende profielen van de Noordoostpolder.

Het tweede gedeelte van het bij dit onderzoek gestelde doel is de verbetering van onvoldoende doorwortelbare profielen. In hoofdstuk V worden de hiervoor gebruikte werktuigen beschreven en verder de resultaten die met ondergrondbewerkingen werden verkregen.

De in het groot uitgevoerde ondergrondbewerkingen, met het daarvoor opgestelde plan en enkele resultaten worden in hoofdstuk VI beschreven. 


\section{WIJZE VAN ONDERZOEK EN ENKELE RESULTATEN}

Bewortelingsonderzoek in het vrije veld is een moeizame bezigheid: Afhankelijk van de gebruikte methode, moet een meer of minder grote hoeveelheid grond worden verplaatst. Vooral bij het nagaan van de invloed van een bepaalde profielopbouw op de wortelontwikkeling kan de te verplaatsen hoeveelheid een grote omvang aannemen.

De in de loop der jaren door verschillende onderzoekers toegepaste methodes worden hierna beknopt weergegeven. Deze methodes berusten of op het uitgraven van kolommen grond, of op het gebruik van grondboren.

Daarna wordt de nauwkeurigheid van het bepalen van wortelhoeveelheden bij het gebruik van naaldenplanken besproken aan de hand van enkele waarnemingen. Bovendien wordt de invloed van het conserveren van wortels met of zonder grond in formaline behandeld.

Tenslotte wordt het resultaat vermeld van een onderzoek naar de verdeling van de wintertarwebeworteling in de bouwvoor en de betekenis hiervan bij het berekenen van wortelhoeveelheden.

\section{Grondkolommen}

WEAVER en medewerkers maakten vlak naast het te bestuderen gewas loopgraven van meer dan $2 \mathrm{~m}$ diep. Deze loopgraven bieden de gelegenheid om op betrekkelijk grote schaal de invloed van de profielopbouw en andere eigenschappen van het profiel op de beworteling te bestuderen. Op deze wijze wordt zowel het wortelbeeld als de reactie van de wortels op bepaalde profieleigenschappen zichtbaar. In de wanden werden de wortelstelsels vrij geprepareerd. De aldus verkregen wortelbeelden werden nagetekend, daar wegens gebrek aan contrast en ruimte fotograferen niet doenlijk was. Het tekenen van de wortels heeft hec voordeel boven fotograferen, dat de onderzoeker wordt gedwongen nauwkeurig na te gaan hoe het wortelstelsel er uitziet.

Om de hoeveelheid wortels te kunnen bepalen, moeten de wortels uit een bepaald volume grond worden gescheiden van de gronddeeltjes. Hiertoe wordt een grondkolom naar een plaats vervoerd, waar, nadat het geheel enige tijd is geweekt, de grond met een regelbare waterstraal tussen de wortels wordt weggespoeld. Daar de grondkolom meestal niet stevig genoeg is om te worden vervoerd, wordt een versteviging aangebracht. 
WEAVER gebruikt daartoe gaas. De grondkolom wordt in zijn geheel of in gedeelten getransporteerd.

Anderen gebruiken een naaldenplank, die vóór of nà het vrijmaken van de grondkolom in de grond wordt gedrukt:

Boonstra sloeg rechthoekige ijzeren kokers in de grond vóór het gewas werd gezaaid. Op het geschikt geachte tijdstip werden deze kokers uit de grond gegraven.

Bij het onderzoek van wortelhoeveelheden in de bouwvoor kan een bepaald blokje van de grond rondom worden vrij gegraven (KöHNLEIN en VETTER) of met een ijzeren bakje worden uitgestoken (KöNEKAMP).

Welke methode zal worden toegepast, hangt af van het inzicht van de gebruiker. Het belangrijkste is bij deze grondkolommen-methode, dat de plaats ten opzichte van de planten en het volume nauwkeurig te bepalen zijn.

\section{Boormonsters}

Het omslachtige graaf- en transportwerk verbonden aan de bovengenoemde methode bracht velen ertoe met behulp van grondboren afgepaste volumes grond aan het profiel te ontlenen en daarin de wortelhoeveelheden te bepalen.

Frhrenbacher en Alexander nemen de grondmonsters machinaal en hebben het uitspoelen van de grondmonsters ook gemechaniseerd. Williams en Baker hebben eveneens een techniek ontwikkeld om de grond mechanisch uit te spoelen op draaiende zeven.

Alle gebruikers wijzen erop dat de volgens de boormethode berekende wortelhoeveelheden per volume-eenheid niet vergelijkbaar zijn met de volgens de grondkolommen-methode verkregen hoeveelheden. $\mathrm{Zij}$ wijzen op de ongelijke verdeling van de wortels in de grond (Кмосн) en op de noodzaak de plaats ten opzichte van de planten goed te bepalen.

Simon en EIcH hebben de resultaten van boormonsters met die van grondblokjes vergeleken. Zij geven de voorkeur aan boormonsters, maar wijzen op de noodzaak van een groot aantal herhalingen (10 à 12). De onregelmatige verdeling van de wortels in de grond noopt tot het nemen van veel herhalingen; meestal wordt echter met een betrekkelijk klein aantal volstaan (3 à 6$)$.

\section{Naaldenplanken}

Voor het onderzoek in de Noordoostpolder werden, in navolging van GOEDFWAAGEN, hoofdzakelijk naaldenplanken gebruikt.

Voor het onderzoek werden naaldenplanken gebruikt in de volgende afmetingen: $100 \times 60 \mathrm{~cm}^{2}, 100 \times 30 \mathrm{~cm}^{2}, 70 \times 35 \mathrm{~cm}^{2}, 55 \times 30 \mathrm{~cm}^{2}$, en $40 \times 25 \mathrm{~cm}^{2}$. De naaldlengte was meestal $13 \mathrm{~cm}$, de langste planken hadden echter naalden van $10 \mathrm{~cm}$.

De naaldenplank werd met behulp van een autokrik in de vlakgemaakte wand van een kuil gedrukt. Daarna werden de zijkanten en de 
onderkant met een mes tot voorbij de naaldpunten vrijgemaakt en vervolgens werd met een soepel staaldraadje de achterzijde losgesneden.

De grond op de naaldenplank werd daarna enige tijd in water geweekt. Ter bevordering van het weken werd soda gebruikt. Anderen gebruiken hiervoor natriumpyrofosfaat.

Indien de grond voldoende zacht werd bevonden, werd deze met een regelbare waterstraal voorzichtig tussen de wortels uitgespoeld. De wortels behouden dan tussen de naalden betrekkelijk goed hun ligging. Indien het wortelbeeld moest worden gefotografeerd, werden de naaldenplanken met wortels in het water gelegd, ter verkrijging van een zo natuurlijk mogelijke ligging.

KöHNLEIN en VETTER hingen de wortels in het water en hadden daarbij, blijkens hun goed geslaagde foto's, geen moeilijkheden met drijvende wortels.

$\mathrm{Na}$ het fotograferen werden de naaldenplanken uit het water gehaald en werden de wortels met een mes of schaar in lagen ingedeeld, meestal in lagen van $10 \mathrm{~cm}$ diepte. De wortels werden daarna zo nodig nog ontdaan van aanhangend vuil, vreemde wortels en van de bovengrondse delen.

De gewichten werden bepaald, nadat de wortels één nacht bij $100^{\circ} \mathrm{G}$ waren gedroogd. As- of zandgehalten werden niet bepaald.

Indien de wortels niet meteen konden worden gereinigd, werden ze bewaard in $4 \%$ formaline.

Vaak was het niet mogelijk op de naaldenplank de zware zavel tussen de wortels weg te spoelen. Deze werd dan mee gefotografeerd. Bij de verdeling in lagen werd uiteraard de achtergebleven grond ook mee verdeeld. De scheiding van wortels uit deze op de plank achtergebleven grond geschiedde over twee zeven. De grond met wortels werd op een zeef met maaswijdte $1 \mathrm{~mm}$ gebracht en daarna krachtig gespoeld, waarbij de wortels op deze zeef achterbleven en konden worden verzameld. Het doorstromende mengsel van grond en water werd zekerheidshalve over een zeef met $0,5 \mathrm{~mm}$ maaswijdte geleid. Op deze fijne zeef werden echter slechts zelden wortelstukjes aangetroffen.

Zo nodig werd de grond met wortels ook in $4 \%$ formaline bewaard.

\section{Onderzoek naar foutenbronnen bij het spoelen en bewaren}

Ten einde enig inzicht te verkrijgen in mogelijke foutenbronnen bij het spoelen en bewaren van de wortels, werd het volgende gedaan:

Van een naaldenplank, $55 \times 35 \times 13 \mathrm{~cm}^{3}$, genomen evenwijdig aan een rij wintertarweplanten, werd de grond tussen de wortels weggespoeld. Het wegstromende water werd over een zeef met $0,5 \mathrm{~mm}$ maaswijdte geleid. Op de plank bleef $11510 \mathrm{mg}$ wortels, op de zeef werd nog $246 \mathrm{mg}$ wortels opgevangen. Een verlies dus van $\pm 2 \%$.

Een naaldenplank, $100 \times 30 \times 10 \mathrm{~cm}^{3}$, genomen in vlas dwars op de rijen over een lengte van $100 \mathrm{~cm}$ en $20 \mathrm{~cm}$ diepte, op overeenkomstige manier behandeld, gaf $19000 \mathrm{mg}$ wortels op de plank en op de zeef 
$363 \mathrm{mg}$. Eveneens een verlies van $\pm 2 \%$.

Een en ander houdt een bevestiging in van het vermoeden, dat bij het scheiden van wortels en grond op de naaldenplanken het wortelverlies betrekkelijk gering is.

Tijdens het transport in en uit de bak waarin werd gefotografeerd, trad enig wortelverlies op. De hoeveelheid werd niet onderzocht, daar deze te zeer afhankelijk is van de wijze van werken. Zo nodig konden de in de fotobak achtergebleven wortels weer an de wortels op de naaldenplank worden toegevoegd.

Het is niet uitgesloten dat het bewaren van de wortels met of zonder grond in formaline het gewicht van de wortels beïnvloedt. Dit, gecombineerd met de mogelijkheid dat het scheiden van wortels en grond over de zeef meer wortels kan opleveren dan het scheiden op de naaldenplank, gaf aanleiding tot het volgende onderzoek:

$\therefore$ Van wintertarwe werden op 31 mei, 1,2 en 3 juni 1955 in totaal acht naaldenplankmonsters genomen (afmetingen $60 \times 30 \times 13 \mathrm{~cm}^{3}$ ), evenwijdig aande rij (rijlengte $60 \mathrm{~cm}$ ). De monsters werden zo genomen, dat het bovengrondse gedeelte van de acht monsters zo gelijkwaardig mogelijk was.

Vier van deze planken werden direct gespoeld. De zich erop bevindende wortels werden voor elke plank in vieren gedeeld, zo, dat wortels van $15 \times 30 \times 13 \mathrm{~cm}^{3}$ apart kwamen. Van elke plank werden vervolgens twee van de vier gedeelten direct schoongemaakt, gedroogd en gewogen. Van de resterende gedeelten van de wortelmonsters der vier planken werden telkens twee monsters $1,2,3$ of 4 maanden in formaline bewaard en daarna schoongemaakt, gedroogd en gewogen.

De grond met wortels van de vier andere planken werd op overeenkomstige wijze in vieren gedeeld. Daarna werden van elke plank telkens twee delen direct over de zeef gespoeld en afgewerkt, en de twee andere delen eerst in formaline bewaard. Op deze delen werd het volgende schema toegepast:

1. Na I maand bewaren: spoelen en verwerken.

2. Na I maand bewaren: spoelen en de wortels nog I maand in formaline.

3. $\mathrm{Na} 2$ maanden bewaren: spoelen en verwerken.

4. Na 2 maanden bewaren: spoelen en de wortels nog 1 maand bewaren in formaline.

Wegens de spreiding bij de duplo's werd de invloed van de verschilIende bewaartijden niet bepaald.

De gemiddelde hoeveelheid wortels bedroeg in de laag $0-10 \mathrm{~cm}$ bij

1. spoelen op de plank en direct verwerken $\quad 1964 \pm 109 \mathrm{mg}$ ( 8 bepalingen)

2. idem en bewaren in formaline. $\quad 2084 \pm 190 \mathrm{mg}$ ( 8 bepalingen)

3. direct spoelen over zeef en verwerken $2560 \pm 143 \mathrm{mg}$ ( 7 bepalingen)

4. bewaren in formaline en daarna spoelen over de zeef

Een van de direct over de zeef gespoelde monsters gaf een zeer grote 
hoeveelheid wortels, vermoedelijk veroorzaakt door een afwijkende struktuur van de grond. Het met dit monster overeenkomende monster van de in formaline bewaarde serie werd daarom ook niet in de berekening van het gemiddelde opgenomen, om een gelijk aantal waarnemingen te houden.

Het al of niet bewaren in formaline heeft blijkbaar geen invloed op de wortelhoeveelheid.

Het spoelen van de grondmonsters over de zeef levert meer wortels op dan bij het scheiden van grond en wortels op de naaldenplanken. Het verschil is echter te groot om alleen uit het verloren gaan van wortels te kunnen worden verklaard. Vermoedelijk wordt bij het spoelen over de zeef een hoeveelheid vezelig materiaal in de zeef opgevangen dat afkomstig is van een voorgaande begroeiing of een onderdeel is van de grond.

KöHNLEIN en VETTER ondervonden dezelfde moeilijkheid bij het scheiden van grond en wortels.

\section{De horizontale verdeling van de wortels in de grond}

Ter verkrijging van een duidelijk verticaal wortelbeeld werden de naaldenplanken meestal evenwijdig aan de gewasrijen genomen. De lengte van de naalden $(10$ of $13 \mathrm{~cm})$ is echter niet in overeenstemming met de rijenafstand der gewassen $(23,25,33$ of $50 \mathrm{~cm})$, zodat, ook indien de gewasrij in het midden van de naaldlengte staat, het volume van de grondkolom niet overeenkomt met het volume dat elke rij planten theoretisch ter beschikking staat. De op deze wijze bepaalde wortelhoeveelheid zal dus alleen met de werkelijkheid overeenkomen, zolang de horizontale uitbreiding van het wortelstelsel de halve naaldlengte niet te boven gaat. Wordt de naaldenplank dwars op de gewasrij geplaatst, dan is het mogelijk (althans bij voldoende afmetingen en juiste plaatsing) de hoeveelheid wortels in het theoretisch ter beschikking staande bodemvolume te bepalen.

Dit zou met een naaldenplank evenwijdig aan de rijen ook wel kunnen, maar de naaldlengte wordt dan -spoedig onhandelbaar groot.

$\mathrm{Bij}$ de voorgaande redenering wordt aangenomen, dat de wortels tussen de rijen niet homogeen zijn verdeeld. SimoN en EIcH vonden verschillende hoeveelheden wortels al naar zij boorden midden op de rij, midden tussen de rijen of van rij tot rij. Op de rijen vonden zij de meeste wortels. Bovendien vonden zij uiteraard ook een spreiding in de op overeenkomstige plaatsen bepaalde hoeveelheden.

Indien de horizontale en vertikale verdeling van de wortels aan een wetmatigheid is onderworpen en deze wetmatigheid bekend is, kan in beginsel uit elk monster, mits plaats en omvang voldoende nauwkeurig bekend zijn, de totale hoeveelheid wortels worden berekend.

De vertikale verdeling is echter te zeer afhankelijk van de aard van het profiel dan dat hiervoor een onder alle omstandigheden geldende regel zou kunnen worden afgeleid. 

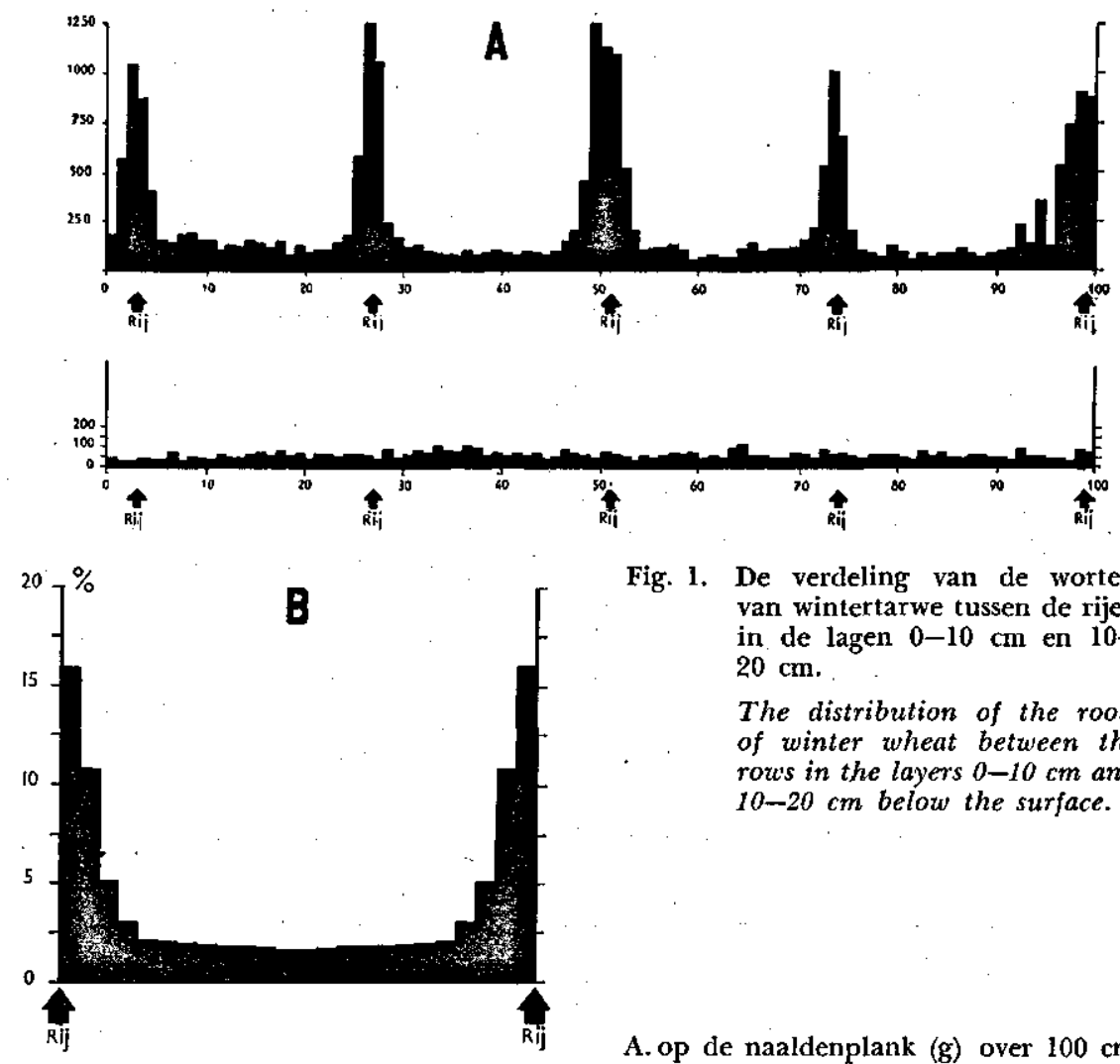

Fig. 1. De verdeling van de wortels van wintertarwe tussen de rijen in de lagen $0-10 \mathrm{~cm}$ en $10-$ $20 \mathrm{~cm}$.

The distribution of the roots of winter wheat between the rows in the layers $0-10 \mathrm{~cm}$ and $10-20 \mathrm{~cm}$ below the surface.

A. op de naaldenplank (g) over $100 \mathrm{~cm}$ lengte.

on the pinboard (g) with a length of $100 \mathrm{~cm}$.

B. gemiddeld van rij tot rij (\%), volgens tabel 1.

the mean from row till row (\%), according to table 1.

De horizontale verdeling biedt meer mogelijkheden, omdat elke gelaagdheid in het profiel uiteraard horizontaal is.

KMoch en FeHrenbacher doelen op een mogelijk verband tussen hoeveelheid en plaats, zonder op het wezen van de ongelijke verdeling in te gaan, evenmin als Simon en EIcH.

Een onderdeel van het bewortelingsonderzoek van de wintertarwe had betrekking op deze horizontale verdeling. Daar deze verdeling van belang is voor de techniek, wordt dit onderzoek hier besproken.

Op 23 juni 1954 werd op kavel .D 31 in de Noordoostpolder kort na de bloei een gewas Heine's VII wintertarwe bemonsterd met een naaldenplank. Deze (afmetingen: $100 \times 30 \times 13 \mathrm{~cm}^{3}$ ) werd over een lengte 
van $100 \mathrm{~cm}$, dwars op de rijrichting, en van $0-30 \mathrm{~cm}$ diepte in de wand van een kuil gedrukt, uit de grond gegraven en naar de spoelplaats gebracht. Daar de rijenafstand $\pm 23 \mathrm{~cm}$ bedroeg, kwamen op deze planken vijf gewasrijtjes voor met vier volledige tussenruimten. De lagen $0-10 \mathrm{~cm}$ en $10-20 \mathrm{~cm}$ werden als een lange koek in plakken gesneden van $1 \mathrm{~cm}$ dikte. (De plakken waren dus evenwijdig aan de rijenrichting (fig. 2a). De sneden werden zo geplaatst, dat de gewasrijen middendoor werden gesneden. Elke plak werd over de zeef van $0,5 \mathrm{~mm}$ maswijdte gespoeld, waarna de wortels zorgvuldig werden verzameld, gedroogd en gewogen.

Figuur I geeft een grafische voorstelling van de op deze manier verkregen wortelhoeveelheden.

Uit deze figuur blijkt zeer duidelijk, dat de systematische horizontale onregelmatigheid beperkt blijft tot de laag $0-10 \mathrm{~cm}$ en dat in de laag $10-20 \mathrm{~cm}$ de onregelmatigheid cen toevallig karakter bezit. De grens $10 \mathrm{~cm}$ beneden de oppervlakte is toevallig; zij is bepaald door de willekeurig gekozen laagdikte van $10 \mathrm{~cm}$. Uit fig. 1 A kan de horizontale verdeling van de wortels in de laag van $0-10 \mathrm{~cm}$, in procenten van de totale hoeveelheid wortels die tot een rij behoren, en in plakken van $1 \mathrm{~cm}$ dik, worden afgeleid. Tabel. 1 en figuur $1 \mathrm{~B}$ geven het resultaat.

TABEL 1. De horizontale verdeling (in $\%$ van de droge stof) van de wortels van wintertarwe (in de laag van $0-10 \mathrm{~cm}$ ), vanaf de rij tot midden tussen de rijen.

\begin{tabular}{l|c|c|c|c|c|c|c}
\hline $\begin{array}{l}\text { Afstand vanafde rij } \\
\text { (in cm) } \\
\begin{array}{l}\text { Distance from the } \\
\text { plant-row (in cm) } \\
\%\end{array}\end{array}$ & $0-1$ & $1-2$ & $2-3$ & $3-4$ & $4-5$ & $5-6$ & $6-7$ \\
\hline & 16.0 & 10.8 & 5.1 & 3.2 & 2.6 & 2.2 & 2.1 \\
$\begin{array}{l}\text { Afstand vanafde rij } \\
\text { (in cm) } \\
\text { Distance from the } \\
\text { plant-row (in cm) } \\
\%\end{array}$ & $7-8$ & $8-9$ & $9-10$ & $10-11$ & $11-12$ & $0-12$ & \\
\hline
\end{tabular}

TABLE 1. Horizontal distribution (in $\%$ of dry matter) of winterwheat roots (in the layer $0-10 \mathrm{~cm})$, from the plant-row till the middle between the rows.

De laag $0-10 \mathrm{~cm}$ bevatte $22401 \mathrm{mg}$ wortels en de laag $10-20 \mathrm{~cm}$ $6301 \mathrm{mg}$. Per grondblok van $10 \times 23 \times 10 \mathrm{~cm}^{3}$ (van midden rij tot midden rij) geeft dit in de laag $0-10 \mathrm{~cm}: 4208.5 \mathrm{mg}$ en in de laag $10-20 \mathrm{~cm}$ : $1160 \mathrm{mg}$ wortels. 


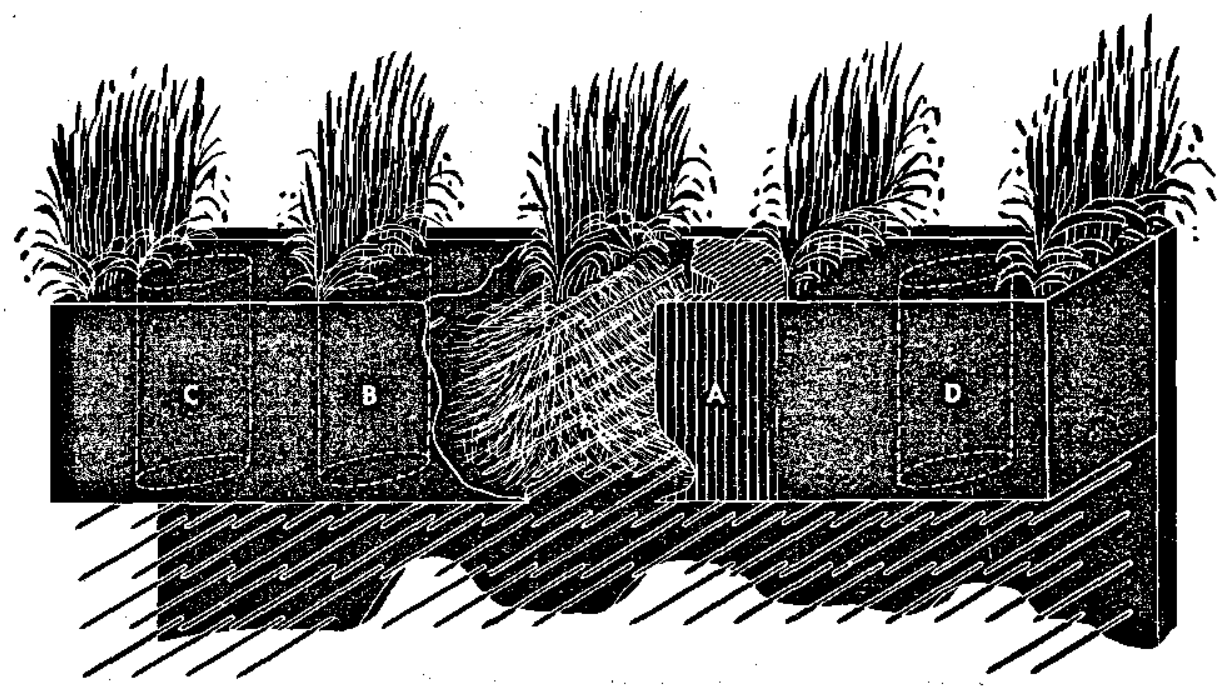

Fig. 2. Schets van een naaldenplank, geplaatst dwars op de rijen van een graangewas: Diagram of a pinboard, placed transwersely to the cereal rows:

a. de grond verdeeld in plakjes van $1 \mathrm{~cm}$ dikte,

$1 \mathrm{~cm}$ thich slices of the soil,

b. een boormonster geplaatst midden op de rij,

auger sample upon the row, c. een boormonster geplaatst tegen de rij, auger sample touching the row,

d. een boormonster geplaatst mid. den tussen de rijen.

auger sample between the rows.

Met behulp van deze horizontale verdeling kan uit de bepalingen, door middel van naaldenplanken gedaan, de totale wortelhoeveelheid worden berekend. Hetzelfde geldt voor de met behulp van grondboren verkregen waarnemingen. Het resultaat is als volgt (uitgedrukt in procenten van een blok van $\left.10 \times 23 \times 10 \mathrm{~cm}^{3}\right)$ :

le. De naaldenplank met naaldlengte $13 \mathrm{~cm}$, geplaatst $3 \mathrm{~cm}$ voor en $10 \mathrm{~cm}$ achter de plantrij, bevat:

in de laag van $0-10 \mathrm{~cm}$ :

$3-0 \mathrm{~cm}+0-10 \mathrm{~cm}=31.9 \%+47.5 \%= \pm 79 \%$ van de wortelhoeveelheid in de laag $0-10 \mathrm{~cm}$.

in de laag van 10-20 cm:

$13 / 23 \times$ gewicht $10-20 \mathrm{~cm}= \pm 56.5 \%$ van de wortelhoeveelheid in de laag van $10-20 \mathrm{~cm}$.

2e. De naaldenplank met naaldlengte $10 \mathrm{~cm}$, geplaatst $3 \mathrm{~cm}$ voor en $7 \mathrm{~cm}$ achter de plantrij, bevat:

in de laag van $0-10 \mathrm{~cm}$ :

$3-0 \mathrm{~cm}+0-7 \mathrm{~cm}=31.9 \%+42 \%= \pm 74 \%$ van de wortelhoeveelheid in de laag van $0-10 \mathrm{~cm}$. 
in de laag van $10-20 \mathrm{~cm}$ :

$10 / 23 \times$ gewicht $10-20 \mathrm{~cm}= \pm 43.5 \%$ van de wortelhoeveelheid in de laag van $10-20 \mathrm{~cm}$.

$3 e$. Wortelhoeveelheid, verkregen met grondboren (in procenten van de hoeveelheid in een kolom van $10 \times 23 \times 10 \mathrm{~cm}^{3}$ ):

Doorsnede boor $10 \mathrm{~cm}$

\begin{tabular}{l|c|c|c}
\hline Geplaatst. & Op de rij $\left.{ }^{\mathrm{y}}\right)$ & Tegen de rij $\left.{ }^{2}\right)$ & Tussen de rijen 3) \\
\hline $\begin{array}{l}\text { In de laag van } \\
0-10 \mathrm{~cm} \\
10-20 \mathrm{~cm}\end{array}$ & 68 & 34 & 14 \\
& 34 & 34 & 34
\end{tabular}

Doorsnede boor $6.5 \mathrm{~cm}$

\begin{tabular}{l|c|c|c}
\hline Geplaatst & Op de rij & Tegen de rij & Tussen de rijen \\
\hline $\begin{array}{l}\text { In de laag van } \\
0-10 \mathrm{~cm}\end{array}$ & 37 & 19 & 6 \\
$10-20 \mathrm{~cm}$ & $\ddots 14$ & 14 & 14
\end{tabular}

1) fig. 2 b. 2) fig. 2 c. 3) fig. 2 d.

De berekening voor de lagen dieper dan $10 \mathrm{~cm}$ volgt uit de verhouding van de volumina der monsters en het blok $10 \times 23 \times 10 \mathrm{~cm}^{3}$,

Op 24 en 25 juni 1954 werd. op hetzelfde perceel wintertarwe de bouwvoor bemonsterd met boren en naaldenplanken. Met een boor, diameter $6.5 \mathrm{~cm}$, werden 10 monsters genomen midden op de rijen van $0-10 \mathrm{~cm}$ en $10-20 \mathrm{~cm}$ diepte, en 6 monsters tegen de rijen aan. Wegens een defect aan de boor konden niet meer monsters worden genomen. Met een andere boor, diameter $10 \mathrm{~cm}$, werden telkens 5 monsters genomen: midden op de rij, tegen de rij aan en tussen de rijen, ook van $0-10 \mathrm{~cm}$ en van $10-20 \mathrm{~cm}$ diepte.

Met naaldenplanken van $35 \times 13 \times 70 \mathrm{~cm}^{3}$ werd de tarwe bemonsterd evenwijdig aan en dwars op de rijen, over een horizontale lengte van 35 c. Hiervan werden uit de lagen $0-10 \mathrm{~cm}$ en $10-20 \mathrm{~cm}$ de wortelhoeveelheden bepaald.

De aldus verkregen grondmonsters werden alle over de zeef gespoeld en daarna op de gebruikelijke manier verwerkt.

De resultaten van deze bemonstering zijn vermeld in tabel 2 , waarbij de bepaalde hoeveelheden volgens de hiervoor beschreven methode zijn omgerekend op een grondblok van $10 \times 23 \times 10 \mathrm{~cm}^{3}$. 
TABEL 2. De wortelhoeveelheden (in $\mathrm{mg}$ ) van wintertarwe, bepaald op verschillende manieren, in een blok van $10 \times 23 \times 10 \mathrm{~cm}^{3}$.

\begin{tabular}{c|c|c|c|c|c|c}
\hline Methode & \multicolumn{2}{|c|}{ Laag $0-10 \mathrm{~cm}$} & \multicolumn{3}{|c|}{ Laag $10-20 \mathrm{~cm}$} \\
& $\begin{array}{c}\text { In het } \\
\text { grondmonster }\end{array}$ & $\%$ & $\begin{array}{c}\text { In een blok } \\
10 \times 23 \times 10 \mathrm{~cm}^{3}\end{array}$ & $\begin{array}{c}\text { In het } \\
\text { grondmonster }\end{array}$ & $\begin{array}{c}\text { In een blok } \\
10 \times 23 \times 10 \mathrm{~cm}^{3}\end{array}$ \\
\hline & & & & & & \\
\hline
\end{tabular}

Uit dit overzicht volgt, dat per boor of naaldenplank reproduceerbare hoeveelheden worden verkregen, zowel in boven- als ondergrond, maar dat de onderlinge hoeveclheden nogal sterk afwijken. Zeer merkwaardig is de invloed van de grootte van het monster op de hoeveelheid wortels in de laag $10-20 \mathrm{~cm}$.

Deze resultaten geven geen aanleiding om aan de bepaalde hoeveelheden wortels, op welke manier dan ook genomen, grote waarde te hechten. Gezien de reproduceerbaarheid, blijkt de wortelverdeling in de bouwvoor in dit geval wel betrouwbaar te zijn. Het blijft echter de vraag, of deze geldig is voor verschillende grondsoorten.

Het is verder de vraag, of de aangegeven verdeling van de wortels in de bouwvoor algemeen geldig is. De in figuur 1 aangegeven verdeling is afgeleid uit bepalingen verricht aan één ras in een bepaalde ontwikkelingstoestand en in één bepaald profiel. De verdeling onder andere omstandigheden is niet onderzocht. Dit kan dus inhouden, dat de aangegeven verdeling toevallig is, al mag deze dan voor de gegeven omstandigheden betrouwbaar zijn, zoals blijkt uit de resultaten van de verschillende bemonsteringsmethoden.

Het ontwikkelingsstadium kan, als gevolg van de aanwezigheid van kroonwortels, de verdeling beïnvloeden. En verder is de invloed van 
ras, bemesting, grondbewerking, rijenafstand e.d. niet uitgesloten. Deze invloed behoeft echter niet groot te zijn, daar in het algemeen in de bouwvoor, behoudens verschil in zwaarte, een goede struktuur kan bestaan. Waar, zoals in de Noordoostpolder, het aantal rassen beperkt is en de vruchtbaarheidstoestand van de grond goed op peil wordt gehouden en geen grote verschillen in rijenafstand voorkomen, mag worden aangenomen dat de wortelverdeling in hetzelfde stadium geen grote verschillen zal vertonen. Wel blijft het een vraag, hoe de verdeling van de wortels is gedurende de groeiperiode van de wintertarwe.

Het bewortelingsonderzoek van de wintertarwe in 1956 op kavel $Q$ 110 (zware zavel) (hoofdstuk III) geeft een aanwijzing, dat de veronderstelde wortelverdeling voor een groot deel van de groeiperiode geldig is. De beworteling werd daar onderzocht met behulp van twee naaldenplanken, één evenwijdig aan, en één dwars op de rijen, hetgeen een mogelijkheid bood, na omrekening van de op deze planken bepaalde hoeveelheden wortels, de betrouwbaarheid van de wortelverdeling gedurende een gedeelte van de groeiperiode te toetsen.

De van beide planken verkregen wortelgewichten werden omgerekend op het wortelgewicht dat behoort bij $10 \mathrm{~cm}$ rijlengte, $23 \mathrm{~cm}$ rijenafstand en $10 \mathrm{~cm}$ diepte.

De dwars op de rijen geplaatste plank omvatte 2 rijtjes wintertarwe met de daarbij behorende ruimte tussen de rijen, totale breedte $46 \mathrm{~cm}$.

De evenwijdig aan de rijen geplaatste plank bevatte $30 \mathrm{~cm}$ rijlengte. De naaldlengte van beide planken was $10 \mathrm{~cm}$, de diepte in de grond $100 \mathrm{~cm}$.

De laag $0-10 \mathrm{~cm}$ bevatte over de periode van begin april tot eind augustus volgens de evenwijdige naaldenplank gemiddeld $1946 \mathrm{mg}$ wortels en volgens de dwarse $1844 \mathrm{mg}$. Het verschil bedroeg $97 \pm$ $122.8 \mathrm{mg}$. Voor de laag van $10-100 \mathrm{~cm}$ bedroegen deze hoeveelheden respectievelijk $1919 \mathrm{mg}$ en $1765 \mathrm{mg}$, met een verschil van $154 \pm 113 \mathrm{mg}$.

Hieruit kan de conclusie worden getrokken, dat het verschil tussen de op twee manieren bepaalde wortelhoeveelheid in de laag van 0-10 $\mathrm{cm}$ niet betrouwbaar is. Voor de laag van $10-100 \mathrm{~cm}$ is het verschil ook niet betrouwbaar, maar het geeft toch wel de indruk dat er een systematische foutenbron zou kunnen zijn.

Voor de ondergrond, waarvoor de omrekening op volumeverhouding is gebaseerd, kan de grootte van het volume invloed hebben. De evenwijdige plank had een kleiner volume dan de dwarse plank, n.1. 27.000 $\mathrm{cm}^{3}$ tegen $41.400 \mathrm{~cm}^{3}$. In overeenstemming met de resultaten van tabel 2 kan het kleinere monster na omrekening een groter wortelgewicht opleveren.

Dit geldt eveneens voor de laag $0-10 \mathrm{~cm}$. Hier is ook nog een andere foutenbron aanwezig. Bij planken evenwijdig aan de rij, met naálden die aan de ene zijde $3 \mathrm{~cm}$ en aan de andere zijde $7 \mathrm{~cm}$ naast de rij uitsteken; zullen bij een rijafstand van $23 \mathrm{~cm}$ de meeste wortels tot deze rij behoren. Zij zitten dus vast aan de planten en kunnen tijdens het spoelen niet wegraken (de naaldenplanken werden direct gespoeld). Bij 
de planken, dwars op de rijen genomen, kan het aantal wortels dat niet tot de op de plank aanwezige rijen behoort, groter zijn. $\mathrm{Bij} 46 \mathrm{~cm}$ breedte en twee rijen op de plank, steekt aan weerszijden $13 \mathrm{~cm}$ naast de rij uit. De hierin voorkomende wortels worden niet door de op de plank aanwezige planten vastgehouden en kunnen dus tijdens het spoelen verdwijnen.

Deze verliezen werden niet gecontroleerd, omdat pas achteraf de verschillen voor de dag kwamen. 


\section{DE ONTWIKKELING VAN HET WORTELSTELSEL IN EEN HOMOGEEN ZAVELPROFIEL}

In de inleiding werd reeds aangegeven, dat voor de beoordeling van het wortelbeeld in verschillende bodemprofielen een normaal wortelstelsel als grondslag moet dienen. De vraag, wat onder een normaal wortelstelsel moet worden verstaan, is echter moeilijk te beantwoorden.

Dit kan een wortelstelsel zijn, dat zich onbelemmerd in alle richtingen heeft kunnen uitbreiden, dus zowel in horizontale als verticale richting. Indien hierbij geen buurplanten aanwezig zijn, zal een vergelijking met het wortelstelsel van een cultuurgewas, dat altijd in een bepaald plantverband wordt geteeld, voor het cultuurgewas een geringere wortelontwikkeling opleveren. Pavlychenko (1937a) vond bij vergelijking van alleenstaande planten met planten op $15 \mathrm{~cm}$ rijenafstand, dat de beworteling van wilde haver, zomertarwe en zomerrogge zowel in de diepte als in de totale lengte beperkt wordt door het zaaien op rijen. Dit gold zowel voor de kiem- als voor de kroonwortels. Bij de alleenstaande planten is het kroonwortelstelsel in totale lengte veel groter dan het kiemwortelstelsel, in tegenstelling tot de rijenteelt, waarbij het kiemwortelstelsel langer is dan het kroonwortelstelsel. Bovendien doet het "onbelemmerd" verschillende nieuwe problemen opkomen. De structuur van het milieu, hetzij grond, water, of een kunstmatig milieu, zal steeds een zekere belemmering uitoefenen, al was het slechts door haar aanwezigheid. Dit laatste is een natuurlijke omstandigheid, overeenkomstig het milieu van landbouwgewassen. De structuur van dit milieu kan evenwel het wortelbeeld beïnvloeden. Dit is ongetwijfeld het geval, indien planten groeien in met grond gevulde kisten (ScHulzE, geciteerd door Goedewaagen). Hierop is door Goedewaagen (1942) dan ook gewezen.

In de oudere literatuur komen opgaven voor van bereikbare diepten voor verschillende gewassen (GoedewaAgen, tabellen, 1942). Deze hebben een beperkte betekenis, omdat slechts een onderdeel wordt gegeven, n.l. de grootste diepte, terwijl gegevens over groeisnelheid en verdeling in de grond ontbreken. VAN LiEsHouT onderzocht van een aantal gewassen de groeisnelheid der wortels. Het kan terecht betwijfeld worden, of deze bereikbare diepten een voorwaarde zijn voor een goede ontwikkeling van de planten. Ervaringen in de Noordoostpolder (GLEveringa, GoEDEWAagen, JoNkER) tonen aan, dat een zeer beperkte diepgang van 
de wortels geen bezwaar behoeft te zijn voor een goede groei, mits voedsel- en vochtvoorziening in orde zijn.

VELDMAN komt op grond van een onderzoek naar de opbrengst van gewassen op klei-op-zand profielen tot de conclusie, dat een profiel van $70 \mathrm{~cm}$ zavel met meer dan $12 \%$ afslibbare delen, op een ondergrond van middelfijn zand, niet zo'n grote opbrengstderving geeft dat inpoldering van dergelijke gronden zou moeten worden ontraden.

Een bereikbare worteldiepte van $100 \mathrm{~cm}$ wordt voldoende geacht voor de behoefte van de gewassen.

Uit de verschillende mogelijkheden voor de bepaling van een ,normaal" wortelstelsel is voor de Noordoostpolder de keuze gevallen op een homogeen zavelprofiel, dat tot $\pm 100 \mathrm{~cm}$ diepte geaëreerd is, met een zomergrondwaterstand van $\pm 150 \mathrm{~cm}$ onder het maaiveld. Homogeen betekent in dit geval de afwezigheid van andere grondsoorten dan zavel (zoals zand, schelpen, veen) en eveneens afwezigheid van zavel met een afwijkende verhoudingen tussen de fractie $<2 \mathrm{mu}$ en 2-16 mu (de sloef). Wel kunnen zavellagen van uiteenlopende zwaarte in een dergelijk profiel voorkomen. Homogeen moet dus niet opgevat worden in de betekenis die Hozksema eraan geeft. Het proces van homogenisatie is ternauwernood begonnen in de Noordoostpolder zodat dit uiteraard nog niet in het onderzoek kon worden opgenomen.

Bij de beschrijving van de wortelstelsels der gewassen zal worden getracht een beeld te geven van de soorten wortels en het voorkomen ervan in het profiel. Vooral wordt aandacht besteed aan de ontwikkeling van het wortelstelsel van het begin tot het einde van de groeiperiode. Dit wortelbeeld is ontstaan uit de waarnemingen in de kuilen op het veld en van de uitgespoelde naaldenplanken. Slechts bij de wintertarwe is de hoeveelheid wortels bepaald. Dit werd bij de overige gewassen achterwege gelaten wegens de grote bewerkelijkheid van het onderzoek. Een eenmalige bepaling van de wortelhoeveelheid werd ondoelmatig geacht, daar deze hoeveelheid te zeer afhankelijk is van het ontwikkelingsstadium van het gewas. $\mathrm{Bij}$ de behandeling van de wintertarwe zal dit blijken.

\section{GraneN}

De benaming van de wortels der gramineeën is ontleend aan het werk van $Z_{1 J L S T R A}$ (1922), in overeenstemming met de benamingen die GoEDEWAAGEN (1942) gebruikt. De kiem- of hoofdwortel is de eerste wortel die bij het kiemen van het zaad te voorschijn komt. De daarna aan de kiemknoop ontstaande wortels worden kiembijwortels genoemd. Kroonwortels ontstaan aan de knopen in de uitstoelingszone en aan de zijspruiten.

Zijwortels die uit de bovengenoemde wortels ontspringen, worden eerste-graads zijwortels genoemd; hieruit ontspringende zijwortels worden tweede-graads zijwortels genoemd, enzovoort. 


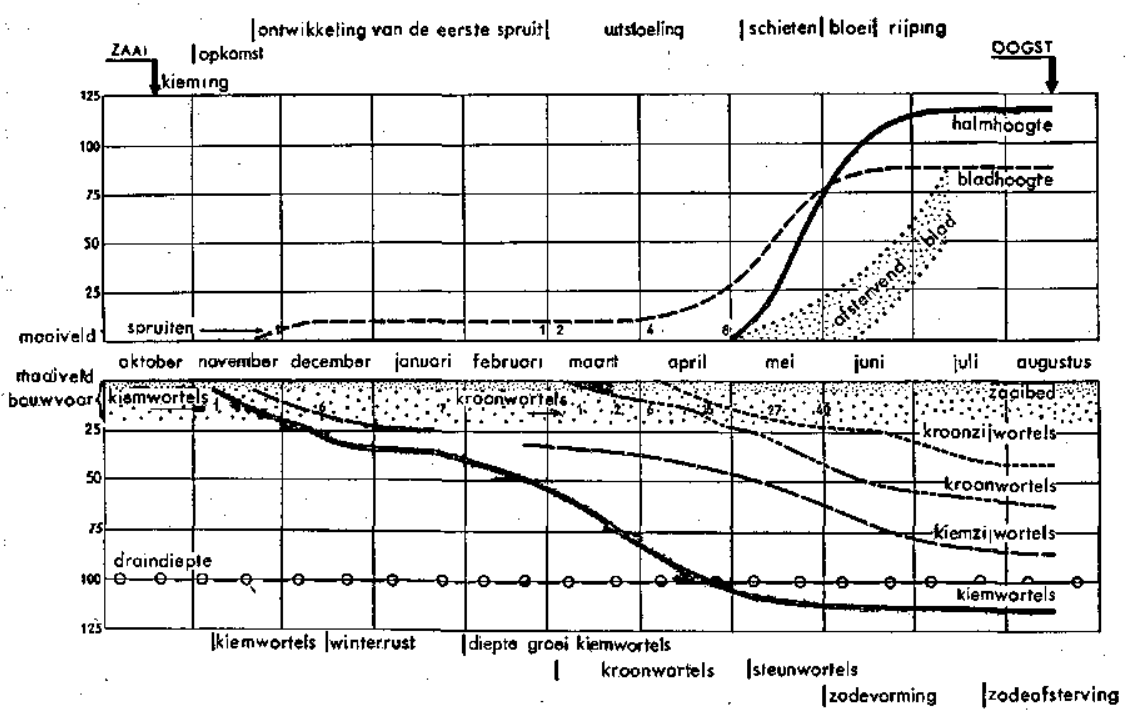

Fig. 3. Schema van de boven- en ondergrondse ontwikkeling van wintertarwe. Diagram of the development of tops and roots of winter wheat ${ }^{1}$ ).

1) For explanation of the terms see pg. 159.

Bij de waarnemingen in de Noordoostpolder zijn geen afwijkingen aangetroffen van dit algemene beeld, zodat t.a.v. deze ontwikkeling naar de genoemde schrijvers kan worden verwezen.

De ontwikkeling van het wortelstelsel wordt door ZiJLSTRA (1939) beschreven tot en met de vorming van de kroonwortels. WEAvER geeft een beschrijving van de gehele ontwikkeling van de wintertarwe; deze is in overeenstemming met de ervaringen in de Noordoostpolder.

\section{Wintertarwe}

In fig. 3 is schematisch aangegeven, hoe de boven- en de ondergrondse ontwikkeling van wintertarwe verloopt.

De lijnen onder en boven het maaiveld geven de grootste diepte en de grootste hoogte aan tot welke de plant in een bepaald groeistadium kwam. De samenhang tussen tijd en groeistadium is wisselend. In de herfst wordt deze vnl. bepaald door de zaai- respectievelijk opkomstdatum. De weersinvloed is in die tijd groot, evenals in het voorjaar.

\section{a. De kiemwortels}

Bij de kieming verschijnt eerst de hoofdwortel (kiemwortel), gevolgd door de kiemschede, het begin van de spruit. Binnen enkele dagen verschijnen enige kiembijwortels, zodat bij het opkomen van de tarwe het plantje bestaat uit de kiemwortel en enige bijwortels (welke tezamen een 10 à $15 \mathrm{~cm}$ diepte hebben bereikt), de zaadkorrel en de bladschede 
met het opgerolde eerste blad. De kiemwortel heeft een iets grotere lengte dan de kiembijwortels. Vervolgens ontspruiten meer kiembijwortels, tot een aantal schommelend om de zes. ZIJLSTRA (1939) geeft een overzicht van de aantallen kiembijwortels van verschillende granen. Het aantal is afhankelijk van gewas en ras. Indien in de herfst slechts enkele kiemwortels ontstaan, kan het aantal in het voorjaar nog toenemen.

De in het najaar bereikte diepte wordt grotendeels bepaald door de tijd gedurende welke de plant groei vertoont. Indien deze voldoende lang is - dus bij vroege zaai (begin oktober) en laat invallen van de vorst - kunnen door de kiemwortels diepten van $\pm 80 \mathrm{~cm}$ worden bereikt. Meestal reiken de kiemwortels echter tot 30 à $50 \mathrm{~cm}$. Na de rustperiode in de winter groeien de kiemwortels door. Dit is een bekend verschijnsel, maar toch wel opvallend omdat de kiemwortels in het voorjaar er vrij dood uit zien, als een draadje vuil garen. De top van de wortel groeit verder. Indien hij om een of andere reden mocht zijn afgestorven, wordt even vớr de top een zijwortel gevormd die in de oorspronkelijke groeirichting doorgaat. Het is aannemelijk, dat de hervatting van de kiemwortelgroei reeds vroeg begint.

In 1952 hadden de kiemwortels op 13 maart reeds een diepte van 士 $80 \mathrm{~cm}$ bereikt, terwijl de hernieuwde groei op een diepte van $\pm 25 \mathrm{~cm}$ was begonnen (vermoedelijk na midden februari, tijdens een zachtere periode).

De kiembijwortels groeien (in afwijking van de verticaal groeiende kiemhoofdwortels) aanvankelijk enigszins uit elkaar om daarna ook recht naar beneden te gaan. Ditzelfde doen de zijwortels. Deze beginnen te voorschijn te komen tijdens het opkomen van het plantje, aanvankelijk bij de basis van de kiemwortels, later ook lager. Enkele malen werden in de herfst tweede-graads zijwortels aangetroffen. $\mathrm{Na}$ de winterrustperiode werd geen nieuwvorming van kiemzijwortels opgemerkt, wel een verlenging. De mogelijke lengte van de kiemwortels is niet bekend. $\mathrm{Op} \pm 100 \mathrm{~cm}$ diepte werden zij meestal geremd door onvoldoende aëratie van de grond. Op het eiland Schokland konden zij tot op $160 \mathrm{~cm}$ worden gevolgd, tot ook daar onvoldoende aëratie de groei stopte.

De kiemwortels hebben een sterke neiging om recht naar beneden te groeien. Dichte kluiten worden zelden gemeden. Scheuren worden wel gevolgd, zolang de richting niet te veel afwijkt van de groeirichting. In tegenstelling tot andere wortels, werd van de kiemwortels niet opgemerkt dat zij boven een zandlaag horizontaal gingen groeien. Indien de zandlaag niet toegankelijk was, eindigde de wortelgroei op of in de zandlaag, waarbij vaak verdikte worteltoppen voorkwamen.

De groeiwijze van de kiemwortels houdt in, dat zij niet in de oppervlakkige lagen groeien.

b. De kroonwortels

Ongeveer tegelijk met de zijspruiten komen de kroonwortels te voor- 
schijn. Laai in het najaar werden enkele afwijkingen opgemerkt. De kroonwortelontwikkeling bleef dan achterwege of kwam pas later op gang. Het is mogelijk, dat dit door de zeer trage groei werd veroorzaakt. Onder gunstige groeiomstandigheden neemt het aantal snel toe.

De groeirichting van de kroonwortels die het eerst gevormd zijn, is aanvankelijk enigszins buitenwaarts gericht en pas daarna verticaal. De later gevormde kroonwortels, dus de jongste, wijken sterk naar buiten af, tot $75^{\circ}$ toe. Op enige afstand van de plant buigen zij om en groeien omlaag.

KRAUS heeft onderzocht, of dit ombuigen wordt beïnvloed door buurplanten. Hij vond, dat de zijwaartse groei onafhankelijk was van de aanwezigheid van wortels van andere planten.

De oudste kroonwortels lijken uiterlijk en in groeiwijze het meest op de kiemwortels. De jongere zijn dikker, verhouten sterk en zijn in de bovenste laag dicht bezet met wortelharen. Deze vormen vaak een viltige laag.

: Goedewaigen noemt deze dikke kroonwortels steunwortels. Zij geven vaak de indruk, vooral indien zij aan knopen boven de grond ontstaan, dat de plant er mee getuid is, om welke reden deze wortels ook ,tuien" kunnen worden genoemd.

De zijwortelvorming bij de kroonwortels is geringer dan bij de kiemwortels en neemt eveneens af van de oudste naar de jongste. Werden bij de oudste kroonwortels nog wel tweede-graads zijwortels aangetroffen, de jongste hadden hoogstens korte eerste-graads zijwortels.

Ofschoon WEAVER vermeldt, dat de kroonwortels een grote diepte bereiken, en GoedewaAgen (1942) het beaamt, is dit bij de onderzochte planten in de Noordoostpolder niet gebleken.

Bij het volgen van deze wortels in een kuilwand breken zij spoedig af. Ook op de naaldenplanken is op enige diepte onder de bouwvoor het onderscheid tussen de kiem- en kroonwortels zeer moeilijk.

Op de schematische voorstelling is de lijn die de dieptegroei van de kroonwortels aangeeft, dan ook onzeker. De verdeling van de wortelhoeveelheden van de wintertarwe in de grond geeft geen aanleiding een grote dieptegroei van de kroonwortels te veronderstellen. De toeneming van de hoeveelheid wortels vindt namelijk hoofdzakelijk plaats in de bouwvoor en niet daaronder (tabel 4 en figuur 5 ).

c. De zode.

Tijdens het uitstoelen en de kroonwortelvorming wordt bovenin de bouwvoor een dicht net van fijne wortels gevormd. Dit zijn alle zijwortels van de kroonwortels. Het is echter niet na te gaan, in welke mate de zijwortelvorming plaats vindt. De vorming van deze zode staat sterk onder invloed van de vochtigheid van de bovengrond. In een droog voorjaar blijkt zij weinig ontwikkeld te zijn of geheel afwezig. Zodra bevochtiging van de grond door regen of anderszins, optreedt, begint de vorming. Het bestaan van deze fijne wortels is vermoedelijk ook afhankelijk van de vochttoestand. Tijdens droge perioden in mei 
kunnen zij verdwijnen (sterven en verteren) terwijl ze bij voldoende vocht weer snel worden gevormd.

d.- De beworteling van uitstoeling tot rijping

De in de herfst (fig. 19) begonnen en in het voorjaar (fig. 20) voortgezette sterke ontwikkeling van kiem- en kroonwortels bereikt haar grootste uitbreiding tijdens het begin van de halmvorming.

Een gedeelte van de gevormde spruiten vormt geen halm. Deze spruiten verdwijnen min of meer spoorloos. Ze worden dun en slap, bleek van kleur en zijn daarna niet meer te vinden tussen de ook gedeeltelijk afstervende onderste bladeren van de gevormde halmen. HäNSEL onderzocht in dit stadium het aantal kroonwortels, daar het niet ondenkbaar was, dat met het verdwijnen van een aantal spruiten de erbij behorende kroonwortels eveneens zouden verdwijnen. Het aantal kroonwortels bleef volgens hem gelijk, zodat hij concludeerde dat de kroonwortels van de verdwenen spruiten werkzaam bleven.

Daar echter in dit stadium nog nieuwe kroonwortels kunnen worden gevormd, is het gelijk blijven van het aantal geen bewijs voor het werkzaam blijven van de bewuste kroonwortels. Op blz. 29 wordt hierop verder ingegaan.

In de bouwvoor komen schommelingen voor door het sterven en de nieuwe vorming van fijne wortels in de zodelaag. Met het vorderen van het ontwikkelingsstadium der planten wordt de hoeveelheid wortels in de zodelaag geringer.

Nieuwvorming van kroonwortels vindt plaats tot omstreeks de tijd dat de aar te voorschijn komt. Zij komen in kransen om de knopen te voorschijn.

Onder de bouwvoor blijven de wortels groeien; de zijwortelvorming lijkt stil te staan.

De kiem- en kroonwortels met hun zijwortels zijn in dit stadium uiterlijk niet meer van elkaar te onderscheiden. Het is niet mogelijk de diepgang van de kroonwortels aan te geven.

e. De gevormde boven- en ondergrondse massa.

In 1956 werden van 9 april-28 augustus 13 bepalingen verricht van de hoeveelheid droge stof, gevormd door wintertarwe op kavel Q 110 in de Noordoostpolder.

Het profiel is daar als volgt:

$0-30 \mathrm{~cm}$ zware zavel A, gr. 6 (zie tabel op blz. 161)

$30-38$,klei A gr. 8

38- 40 , fijn zand ' gr. 2. f.

$40-80$, zware zavel B, gr. 7

$80-100$, zware zavel A, gr. 6

Dit profiel voldoet in grote trekken aan het begrip ,homogeen zavelprofiel". Het zandlaagie had geen storende invloed, was plaatselijk zeer dun of slechts merkbaar door een dun laagje schelpen. 
TABEL 3. Gemiddelde gewichten van boven-en ondergrondse delen van Heine's VII wintertarwe op kavel Q 110 in 1956 per spruit/halm (in mg droge stof).

\begin{tabular}{|c|c|c|c|c|}
\hline \multirow{2}{*}{ Datum } & \multirow{2}{*}{$\begin{array}{l}\text { Mg per spruit } \\
\text { of halm }\end{array}$} & \multicolumn{3}{|c|}{$\mathrm{Mg}$ wortels per spruit of halm } \\
\hline & & $0-10 \mathrm{~cm}$ & $10-100 \mathrm{~cm}$ & $0-100 \mathrm{~cm}$ \\
\hline $\begin{array}{c}9 \text { april } \\
23 \text { " } \\
5 \text { mei } \\
12 " \\
19 " \\
26 " \\
26 " \\
9 \text { juni } \\
23 " \\
6 \text { juli } \\
21 " \\
2 \text { augustus } \\
22 ",\end{array}$ & $\begin{array}{r}64 \\
89 \\
165 \\
293 \\
420 \\
573 \\
1165 \\
1549 \\
2370 \\
2410 \\
2675 \\
3170 \\
2670\end{array}$ & $\begin{array}{r}14.5 \\
15.0 \\
32.5 \\
54.0 \\
73.0 \\
82.5 \\
168.0 \\
141.5 \\
189.5 \\
135.5 \\
170.5 \\
186.5 \\
155.0\end{array}$ & $\begin{array}{r}32.0 \\
-49.5 \\
53.0 \\
71.1 \\
75.3 \\
113.7 \\
144.7 \\
103.7 \\
130.6 \\
112.8 \\
140.1 \\
118.8 \\
120.5\end{array}$ & $\begin{array}{r}46.5 \\
64.5 \\
85.5 \\
125.1 \\
148.3 \\
196.2 \\
312.7 \\
245.2 \\
320.1 \\
248.3 \\
310.6 \\
305.3 \\
275.5\end{array}$ \\
\hline \multirow[t]{2}{*}{ Date } & $M g$ shoot & \multicolumn{3}{|c|}{$M g$ roots per shoot } \\
\hline & & $0-10 \mathrm{~cm}$ & $10-100 \mathrm{~cm}$ & $0-100 \mathrm{~cm}$ \\
\hline
\end{tabular}

TABLE 3. Mean weights of lops and roots of Heine VII winterweheat on parcel Q 110 in 1956 (in $\mathrm{mg}$ dry matter per shoot).

De Heine's VII wintertarwe was gezaaid op 5 oktober; voorvrucht 1953 en 1954: luzerne, 1954-'55: winterkoolzaad. De bemesting bestond uit $200 \mathrm{~kg}$ per ha superfosfaat en $300 \mathrm{~kg}$ per ha kalkammonsalpeter. De opbrengst was per ha $4550 \mathrm{~kg}$ zaad en $\pm 6000 \mathrm{~kg}$ stro.

Het weer was in 1956 niet normaal. Het voorjaar was schraal, zodat het gewas pas vrij laat (begin april) begon te groeien. De uitstoeling, die in het najaar was begonnen, vorderde weinig. Midden mei begon de stengelvorming. Begin juni kwam het gewas in de aar. Begin juli begon een periode met zware regenval, die tot september aanhield. Het gewas was begin augustus rijp, maar kon pas eind augustus worden geoogst.

In het gewas werden per bemonsteringsdatum twee naaldenplankmonsters genomen. Met een naaldenplank $30 \times 100 \times 10 \mathrm{~cm}^{3}$ werd het gewas evenwijdig aan de rijen bemonsterd; met een naaldenplank $60 \times 100 \times 10 \mathrm{~cm}^{3}$. werd het gewas dwars op de rijen bemonsterd, zodanig dat twee rijtjes ter lengte van $10 \mathrm{~cm}$ (naaldlengte) symmetrisch verdeeld in het monster zaten. 
Deze naaldenplankmonsters werden op de eerder beschreven manier genomen en verwerkt. De planten (spruiten, halmen) werden geteld en daarna in het laboratorium van de Directie van de Wieringermeer te Kampen gedroogd en gewogen. De wortels werden verdeeld in lagen van $10 \mathrm{~cm}$ diepte, te beginnen met $0-10 \mathrm{~cm}$ en eindigend met 90-100 $\mathrm{cm}$. De wortels van de dwars op de rij genomen planken werden voor deze verdeling afgesneden op $46 \mathrm{~cm}$ breedte, d.w.z. dus $2 \times$ rijenafstand. De wortelhoeveelheden van deze planten geven dus zonder meer aan de bij $2 \times 10 \mathrm{~cm}$ rijlengte en $23 \mathrm{~cm}$ rijenafstand behorende gewichten.

De wortelhoeveelheden van de evenwijdig aan de rij genomen naaldenplanken werden omgerekend op de wijze als in hoofdstuk $I$ is aan-

TABEL 4. Gemiddelde gewichten van boven- en ondergrondse delen van Heine's VII wintertarwe op kavel $Q 110$ in 1956 per $10 \mathrm{~cm}$ rijlengte (in mg droge stof).

\begin{tabular}{|c|c|c|c|c|c|c|}
\hline Datum & $\begin{array}{l}\text { Spruiter } \\
\text { Aantal }\end{array}$ & $\begin{array}{l}\text { halmen } \\
\text { Gewicht }\end{array}$ & $0-10 \mathrm{~cm}$ & $\begin{array}{c}\text { Wortels } \\
10-100 \mathrm{~cm}\end{array}$ & $0-100 \mathrm{~cm}$ & Stadium $\left.^{1}\right)$ \\
\hline 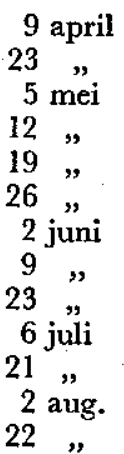 & $\begin{array}{l}25 \\
29.5 \\
28 \\
25.5 \\
29 \\
25.5 \\
16 \\
20 \\
16 \\
16 \\
14.5 \\
14 \\
11.5\end{array}$ & $\begin{array}{r}1536 \\
2632 \\
4654 \\
7393 \\
12228 \\
14592 \\
18840 \\
26651 \\
36919 \\
39424 \\
38526 \\
42990 \\
30799\end{array}$ & $\begin{array}{r}357 \\
426 \\
900 \\
1350 \\
2197 \\
2047 \\
2685 \\
2872 \\
2950 \\
2215 \\
2427 \\
2535 \\
1737\end{array}$ & $\begin{array}{r}786 \\
1409 \\
1475 \\
1763 \\
2127 \\
2746 \\
2346 \\
2080 \\
2447 \\
1829 \\
1964 \\
1628 \\
1352\end{array}$ & $\begin{array}{l}1143 \\
1835 \\
2375 \\
3113 \\
4324 \\
4793 \\
5031 \\
4952 \\
5397 \\
4044 \\
4391 \\
4163 \\
3089\end{array}$ & $\begin{array}{c}3 \\
4 \\
5 \\
\\
7 \\
8 \\
9 \stackrel{\mathrm{a}}{10} \\
10.1 \\
10.5 \\
10.5 .4 \\
11.1 \\
\\
11.4\end{array}$ \\
\hline Date & $\begin{array}{r}\text { Number } \\
S\end{array}$ & Weight & $0-10 \mathrm{~cm}$ & $\begin{array}{c}\mid 10-100 \mathrm{~cm} \\
\text { Roots }\end{array}$ & $0-100 \mathrm{~cm}$ & Stage $\left.^{1}\right)$ \\
\hline
\end{tabular}

ГABEL 4. Mean weights of tops and roots of Heine VII winterwheat on parcel $Q 110$ in 1956 (in $\mathrm{mg} d r y$ matter) per $10 \mathrm{~cm}$ length of row.

1) Volgens de schaal van Feekes (LARGE). According to the Feekes scale (LARGE). Stadium

$\begin{array}{lll}\text { Stage } & & \\ 3-5 & \text { uitstoelen } & \text { tillering } \\ 6-10 & \text { strekking } & \text { stem extension } \\ 10.1-10.5 & \text {. in de aar } & \text { heading } \\ 11- & \text { rijping } & \text { ripening }\end{array}$




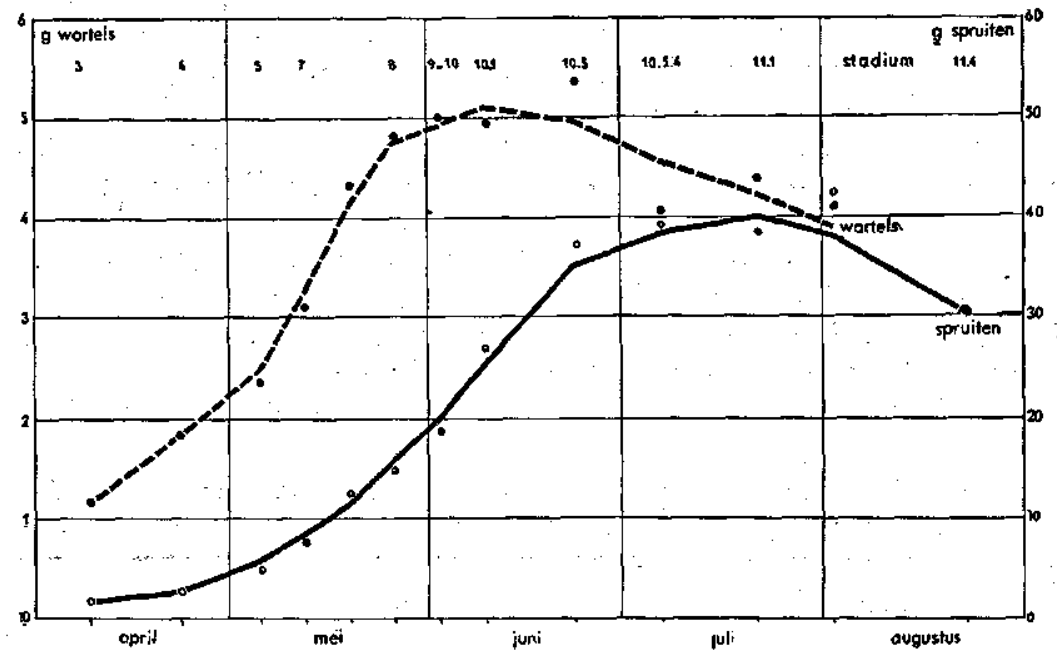

Fig. 4. Hoeveelheden (g droge stof) wortels en spruiten (halmen) van de wintertarwe op kavel $Q 110$ op achtereenvolgende data in 1956, volgens tabel 3.

Amounts (g dry matter) of tops and roots of winter. wheat on parcel $Q 110$ on succeeding dates in 1956, according to table 3.

gegeven voor $10 \mathrm{~cm}$ rijlengte, $23 \mathrm{~cm}$ rijenafstand en $10 \mathrm{~cm}$ diepte.

De van de dwars op de rijen geplaatste naaldenplanken verkregen wortelgewichten gaven na halvering het verlangde gewicht.

De tabellen 3 en 4 geven een overzicht van de bovengrondse massa en de hoeveelheid wortels in de lagen $0-10 \mathrm{~cm}$ en $10-100 \mathrm{~cm}$, per spruit of halm en per rijlengte van $10 \mathrm{~cm}$, op de verschillende data. Deze gegevens zijn de gemiddelden van de op elke datum genomen twee naaldenplanken.

Figuur 4 brengt deze cijfers in beeld. De door de lijn verbonden punten stellen de gewogen gemiddelden van telkens drie opeenvolgende data voor.

Ofschoon bij het nemen van de naaldenplanken zoveel mogelijk rijen met een gelijkmatige en vergelijkbare'standdich theid werden uitgezocht, bleek het niet mogelijk schommelingen in aantal spruiten of halmen per rijlengte te vermijden. Deze schommelingen, welke blijken uit de vermelde aantallen, veroorzaken afwijkingen in de wortelgewichten per spruit of halm. Hieruit kan worden afgeleid, dat het wortelgewicht een zekere onafhankelijkheid vertoont t.o.v. de standdichtheid. In welke mate deze onafhankelijkheid geldt, kan uit de beschikbare gegevens niet worden afgeleid. Het bestaan ervan is echter in overeenstemming met hetgeen Lisshout uit de literatuur aanhaalt over het gevormde aantal 
wortels van wintertarwe bij verschillende aantallen planten in een onderzoek van Clements-Weaver en Hanson. Bij vier standdichtheden $(1 / 2,1,2$ en $4 \times$ normaal $)$ bedroeg het gemiddelde aantal wortels per plant $37,24,13$ en 9. Het aantal wortels per lengte-eenheid wordt daardoor genivelleerd en daar de wortelhoeveelheid afhankelijk is van het aantal, het wortelgewicht ook.

OPITz onderzocht de invloed van de standruimte op de hoeveelheid wortels bij zomergerst. $\mathrm{Bij}$ een standruimte van $10-200 \mathrm{~cm}^{2}$ per plant vond hij een constant wortelgewicht per halm.

Voor de wintertarwe kan de standruimte per plant op $2.5 \times 23 \mathrm{~cm}^{2}=$ $57.5 \mathrm{~cm}^{2}$ worden geschat. Indien de zomergerst van OPITZ vergelijkbaar is met de Heine's VII wintertarwe, zou het wortelgewicht niet onafhankelijk zijn van het aantal halmen.

HÄNSEL legt een verband tussen de bodemvruchtbaarheid en het aantal spruiten (halmen) in die zin, dat bij toenemende vruchtbaarheid het aantal tot wasdom komende spruiten groter wordt. Daar de vruchtbaarheid eveneens de hoeveelheid wortels kan beïnvloeden, zal het verband tussen hoeveelheid wortels, aantal spruiten en standruimte wel niet zo eenvoudig zijn als de aangehaalde auteurs het voorstellen.

Duidelijk blijkt uit figuur 4, dat de wortelontwikkeling vooruitloopt op de bovengrondse ontwikkeling. In de schematische voorstelling (fig. 3) kwam dit reeds tot uiting door vergelijking van de groei in de diepte met die in de hoogte. De wortels hebben reeds hun grootste diepte bereikt ten tijde van het begin van de halmvorming. Het verloop van de gewichten is hiermede geheel in overeenstemming. In een zacht voorjaar kan dit verschil vermoedelijk nog wel groter zijn.

Uit de spruit- en wortelgewichten (tabel 3 en 4) blijkt eveneens, dat tot het schieten de bovengrondse ontwikkeling slechts langzaam toe: neemt, maar daarna snel stijgt.

In figuur 5 zijn de wortelhoeveelheden op de verschillende data laagsgewijs aangegeven per $10 \mathrm{~cm}$ rijlengte. De bovenste lijn, welke de totale wortelhoeveelheid aangeeft, komt dan overeen met de lijn in figuur 4, die de wortelhoeveelheden aangeeft.

Door deze voorstelling wordt een duidelijk beeld verkregen van de plaatsen met de sterkste wortelgroei.

In overeenstemming met tabel 4 bevindt zich in de laag $0-10 \mathrm{~cm}$ ongeveer de helft van het totale wortelgewicht. De toeneming is hier bij het inzetten van de voorjaarsgroei het sterkst. De wortelgewichten in de lagen dieper dan 40 à $50 \mathrm{~cm}$ blijven vrijwel constant. De schommelingen die daar voorkomen, zullen grotendeels bepalingsfouten zijn. Bij het betrekkelijk geringe aantal wortels dat op deze diepte voorkomt, kunnen enkele wortels meer of minder het gewicht beïnvloeden. In de laag $30-40 \mathrm{~cm}$ is het wortelgewicht lager dan op grond van een regelmatige afneming bij een toenemende diepte zou moeten worden verwacht. Deze laag bestaat grotendeels uit klei A en een zandlaagje van wisselende dikte. In de klei is de beworteling niet regelmatig verdeeld, 


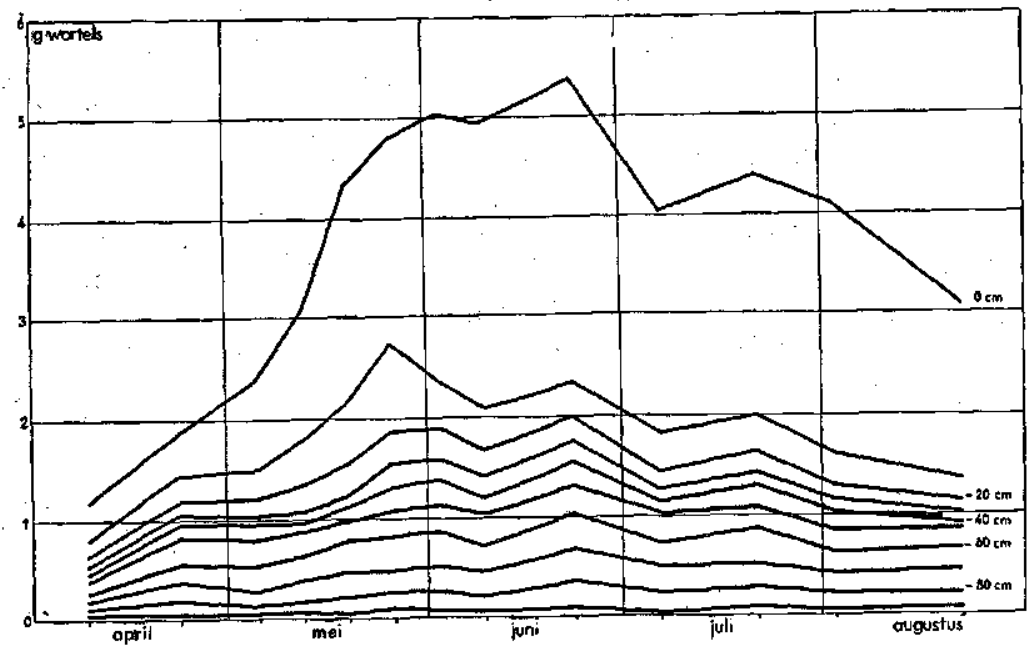

Fig. 5. Verdeling van de hoeveelheden ( $g$ droge stof in blokken van $10 \times 23 \times$ $10 \mathrm{~cm}^{3}$ ) wortels van wintertarwe over het profiel van $0-100 \mathrm{~cm}$, op achtereenvolgende data.

Distribution ( $g$ dry matter) of the roots of winter wheat in the profile $(0-100 \mathrm{~cm})$ on succeeding dates. The distance between two lines gives the amount of raots in a $10 \mathrm{~cm}$ thick layer, for a row of $10 \mathrm{~cm}$ and a row distance of $23 \mathrm{~cm}$.

maar sterker in scheuren geconcentreerd dan in de zavellagen. Het is mogelijk, dat de zijwortelvorming hierin is achter gebleven. Het zandlaagje kan eveneens invloed hebben gehad, door grotere zijwortelvorming te verhinderen. Gezien de geringe dikte, is zijn betekenis vermoedelijk niet groot geweest, te meer omdat het bij slechts enkele bepalingen dikker dan $1 \mathrm{~cm}$ was.

De grote hoeveelheid wortels in de laag $0-10 \mathrm{~cm}$ en ook nog in de laag $10-20 \mathrm{~cm}$ kan op rekening van de kroonwortels worden gesteld. Dit is in overeenstemming met hetgeen werd medegedeeld over de horizontale verdeling in de bouwvoor (hfdst. I).

De verdeling van de wortelhoeveelheden en de totale hoeveelheid vertonen enkele afwijkingen.

Op 26 mei is de hoeveelheid in de tweede laag groter dan daarvoor en daarna. De totale wortelhoeveelheid wordt hierdoor niet beinvloed. De meest aannemelijke verklaring is, dat bij het spoelen van de naaldenplanken, ondanks alle voorzorgen, toch een verschuiving van de wortels van boven naar beneden heeft plaatsgehad. Het teveel in de laag van $10-20 \mathrm{~cm}$ zou afkomstig zijn van de laag $0-10 \mathrm{~cm}$, die dan een te laag gewicht zou hebben.

Het totale gewicht op 9 juni is iets lager dan op de voorgaande en 
volgende data. In de lagen $0-10 \mathrm{~cm}, 30-40 \mathrm{~cm}$ en $50-60 \mathrm{~cm}$ is het wortelgewicht hoger dan het gemiddelde van de omringende data, in de overige lagen is het gewicht lager.

De eenvoudigste verklaring is het veronderstellen van een toevallige afwijking. In deze periode laat de vergelijkbaarheid van de beide naaldenplanken veel te.wensen over in de bovenste laag, terwijl het gemiddelde van de beide planken goed in het verloop past. De overeenstemming in de overige lagen is juist goed, voor beide planken is de hoeveelheid wortels echter lager dan overeenkomt met de omringende data. Op 9 juni was het aantal halmen op beide planken per $10 \mathrm{~cm}$ lengte groter, n.l. gemiddel 4 meer dan daarvoor en daarna. Het is niet onmogelijk, dat in dit stadium de standdichtheid wel enige invloed op de wortelhoeveelheid heeft. Want in deze tijd (de overgang van uitstoeling naar halmvorming) verdwijnt een aantal spruiten. Het is nu de vraag, of bij het verdwijnen van deze spruiten de bijbehorende kroonwortels al of niet ten dienste van de plant blijven functioneren. Algemeen wordt aangenomen, voor zover dit probleem wordt aangesneden, dat het gehele wortelstelsel intact blïft.

Tijdens de waarnemingen in het veld werd het afsterven van de bij de verdwijnende spruiten behorende wortels niet waargenomen. Bovendien verteren de dode wortels in deze tijd snel, omdat het warm en vochtig kan zijn.

Op 6 juli is de afwijking van de omringende data groot. Beide planken gaven over de gehele diepte lage wortelhoeveelheden.

Ook hier is een toevallige afwijking de eenvoudigste verklaring. Deze toevalligheid kan zowel het profiel betreffen als de behandeling. De bovengrondse massa (grafiek) geeft echter geen aanwijzingen, dat de naaldenplanken op een afwijkende plaats zouden zijn genomen.

Het gewas verkeerde in het melkrijpe stadium. Het is nog niet te - begrijpen, waarom juist dan de wortelhoeveelheid zou verminderen, om vervolgens weer toe te nemen en daarna weer te dalen. Het weer geeft evenmin aanleiding tot de veronderstelling van het uitoefenen van enige invloed. Het was in de voorafgaande week niet uitzonderlijk droog of nat, omstandigheden waarvan wel is opgemerkt, dat zij de hoeveelheid wortels in het zodelaagje kunnen beïnvloeden.

In een soortgelijk onderzoek bij winterrogge vond KöNEKAMP geen afwijkingen. $\mathrm{Hij}_{\mathrm{j}}$ bepaalde de hoeveelheid wortels in de laag $0-30 \mathrm{~cm}$ en vond de volgende waarden:

Begin schieten
Aar zichtbaar
Geschoten
Melkrijp
Oogst

$\begin{array}{rrr}4 \text { mei } 1951 & 15.6 \mathrm{dz} / \mathrm{ha} \\ 10 " 1951 & 18.6 " \\ 25 \text { " } 1951 & 20.9 " \\ 4 \text { juli } 1951 & 20.4 " \\ 6 \text { aug. } 1951 & 15.5 "\end{array}$

In tekening geeft dit een zeer (te mooi) vloeiend verloop, dat grote overeenkomst vertoont met het verloop van de wortelhoeveelheden in fig. 5. Het ontbreken van afwijkingen in de gegevens van KöNEKAMP vormt 
geen bewijs voor het niet voorkomen ervan, daar de bepalingen met vrij grote tussenpozen zijn verricht. De afwijkingen werden blijkbaar ook niet verwacht. Indien in figuur 4 alleen de met de winterrogge overeenkomende stadia worden genomen $(6,10.1,10.5,11.1$ en 11.4$)$, ontstaat eveneens een vloeiend verloop.

Uit figuur 5 blijkt, dat na de korrelzetting de hoeveelheid wortels achteruitgaat en wel voornamelijk in de bovenste lagen. Dit is in overeenstemming met hetgeen KöNEKAMP vond bij winterrogge. De overeenkomst is te duidelijker, omdat hij slechts de laag van $0-30 \mathrm{~cm}$ bemonsterde.

In de ondergrond blijft de wortelhoeveelheid dezelfde.

In 1957 werd opnieuw gelegenheid gevonden het verloop van de boven- en ondergrondse ontwikkeling van een wintertarwegewas te volgen, nu op kavel D 22 .

Het profiel is als volgt: (zie tabel, blz. 161).

$0-20 \mathrm{~cm}$ lichte zavel A gr 4;

20-50, zeer fijn kleihoudend zand gr. 2 d Espelzand;

50-60 " lichte zavel $\mathrm{B}$ gr. 5 Z u s;

60-67 " lichte zavel A . gr. 4 sloef.

Deze kavel is in de herfst van 1952 tot $70 \mathrm{~cm}$ diepte losgemaakt met de zg. Neptunus (zie blz. 88).

De Carsten's VI wintertarwe is gezaaid op 25 oktober 1956 naar 146 $\mathrm{kg} / \mathrm{ha}$; voorvrucht: groene erwten; bemesting: $400 \mathrm{~kg} / \mathrm{ha}$ superfosfaat voor het zaaien, $500 \mathrm{~kg} / \mathrm{ha}$ kalkammonsalpeter in het voorjaar. Gedurende de bemonsteringsperiode van 6 april tot 24 juli werden in het gewas geen verplegings- of andere werkzaamheden verricht. In het begin van de periode werden de toekomstige bemonsteringsplaatsen uitgezocht . op onderlinge gelijkmatigheid van stand en ontwikkeling en aangeduid met een genummerd steeketiket.

Een naaldenplank van $100 \times 30 \times 10 \mathrm{~cm}^{3}$ werd gebruikt dwars op de rijen zodanig, dat een blok van $100 \mathrm{~cm}$ lengte (waarin 4 tarwerijtjes van $10 \mathrm{~cm}$ ) en $30 \mathrm{~cm}$ diepte uit de grond werd gehaald. De rijenafstand bedroeg $25 \mathrm{~cm}$.

$\mathrm{Na}$ een zachte winter volgde een droog voorjaar met een lange schrale periode. Het weer was in mei en juni zeer gelijkmatig droog en warm. In de eerste helft van juli kwamen enkele zware onweersbuien voor en in de tweede helft enkele langere regenperioden. De maand juli was nogal regenachtig, met evenwel lange perioden van droog weer.

Het gewas begon voor de winter reeds uit te stoelen. Dit proces ging 'gedurende de winter langzaam door. Eind maart-begin april begon de vorming van de pseudostengel (stadium 4), omstreeks $8 \mathrm{mei}$ was de eerste knoop zichtbaar (stadium 6) en 29 mei stond het gewas in schotblad (stadium 8). Midden juni stond het gewas in de aar (stadium 10.5) en een maand later was het bijna rijp (stadium 11.3). 
TABEL 5. Gemiddelde gewichten van boven- en ondergrondse delen van Carsten's VI wintertarwe op kavel D 22 in 1957 per $10 \mathrm{~cm}$ rijlengte (in mg droge stof).

\begin{tabular}{|c|c|c|c|c|c|c|c|c|c|}
\hline \multirow[b]{2}{*}{ Datum } & \multicolumn{3}{|c|}{ Aantal } & \multicolumn{3}{|c|}{ Gewicht } & \multicolumn{3}{|c|}{ Gewicht der wortels } \\
\hline & Planten & $\begin{array}{c}\text { Norma- } \\
\text { le sprui- } \\
\text { ten }\end{array}$ & $\begin{array}{c}\text { Kleine } \\
\text { sprui- } \\
\text { ten }\end{array}$ & $\begin{array}{c}\text { Kleine } \\
\text { sprui- } \\
\text { ten }\end{array}$ & $\begin{array}{l}\text { Norma- } \\
\text { le sprui- }\end{array}$ & Zaad & $\begin{array}{c}0-10 \\
\mathrm{~cm}\end{array}$ & $\left|\begin{array}{c}10-30 \\
\mathrm{~cm}\end{array}\right|$ & $\begin{array}{c}0-30 \\
\mathrm{~cm}\end{array}$ \\
\hline $\begin{array}{r}6.4 \\
13.4 \\
18.4 \\
24.4 \\
27.4 \\
3.5 \\
8.5 \\
11.5 \\
15.5 \\
18.5 \\
22.5 \\
25.5 \\
29.5 \\
1.6 \\
5.6 \\
12.6 \\
15.6 \\
19.6 \\
22.6 \\
26.6 \\
29.6 \\
3.7 \\
6.7 \\
10.7 \\
13.7 \\
17.7 \\
20.7 \\
24.7\end{array}$ & $\begin{array}{l}7.5 \\
9.25 \\
10 \\
9.25 \\
8.25 \\
8 \\
9.75 \\
9.75 \\
9.5 \\
9.25 \\
7.25 \\
7 \\
6.75 \\
6.5 \\
6.75 \\
6.5 \\
5.25 \\
4.75 \\
6 \\
5.25 \\
6.25 \\
7 \\
5 \\
6 \\
6.5 \\
5.75 \\
6.5 \\
7.75\end{array}$ & $\begin{array}{l}21.5 \\
23.5 \\
24.75 \\
23.5 \\
22.25 \\
22 \\
23.75 \\
18.25 \\
17.25 \\
16 \\
15.5 \\
14.25 \\
11.75 \\
11.25 \\
13.25 \\
11 \\
10.75 \\
10.5 \\
13.25 \\
11.5 \\
10.75 \\
14 \\
11 \\
13.25 \\
13.5 \\
12.75 \\
13.25 \\
14\end{array}$ & $\begin{array}{l}6 \\
5.75 \\
7.75 \\
7 \\
6.5 \\
8.5 \\
8.5 \\
7.75 \\
9.75 \\
10.25 \\
7.5 \\
7.25 \\
6 \\
8 \\
6 \\
7.75 \\
4.75 \\
6.75 \\
6.25 \\
4 \\
6.75\end{array}$ & $\begin{array}{r}858 \\
895 \\
880 \\
1005 \\
745 \\
750 \\
540 \\
713 \\
623 \\
620 \\
523 \\
748 \\
550 \\
265 \\
560\end{array}$ & 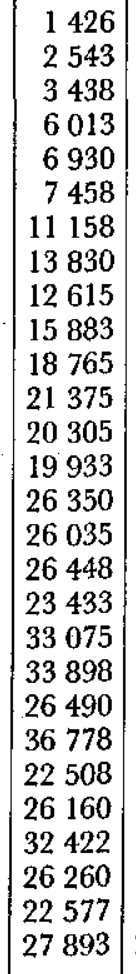 & \begin{tabular}{|r|} 
\\
\\
\\
\\
\\
\\
\\
\\
\\
\\
\\
\\
\\
\\
\\
\\
\\
\\
2625 \\
3688 \\
9050 \\
8050 \\
13680 \\
18593 \\
17598 \\
16318 \\
22050
\end{tabular} & $\begin{array}{r}290 \\
658 \\
1009 \\
1575 \\
1620 \\
1731 \\
2099 \\
2229 \\
2507 \\
2279 \\
2010 \\
2661 \\
2230 \\
2018 \\
2213 \\
2429 \\
2277 \\
2568 \\
2636 \\
2379 \\
1945 \\
2277 \\
1785 \\
1801 \\
2220 \\
1794 \\
1504 \\
1650\end{array}$ & $\begin{array}{r}279 \\
543 \\
711 \\
874 \\
1056 \\
1151 \\
994 \\
1311 \\
1426 \\
1270 \\
1029 \\
1200 \\
1329 \\
836 \\
1275 \\
1578 \\
971 \\
1475 \\
1277 \\
1397 \\
1298 \\
1303 \\
1302 \\
1132 \\
976 \\
1157 \\
988 \\
829\end{array}$ & $\begin{array}{r}569 \\
1201 \\
1720 \\
2449 \\
2676 \\
2882 \\
3093 \\
3540 \\
3933 \\
3549 \\
3039 \\
3861 \\
3559 \\
2854 \\
3488 \\
4007 \\
3248 \\
4043 \\
3913 \\
3776 \\
3243 \\
3580 \\
3087 \\
2933 \\
3196 \\
2951 \\
2492 \\
2479\end{array}$ \\
\hline Date & Plants & Shoots & $\begin{array}{l}\text { Small } \\
\text { shoots }\end{array}$ & $\begin{array}{l}\text { Small } \\
\text { shoots }\end{array}$ & Shoots & Seed & $\begin{array}{c}0-10 \\
\mathrm{~cm}\end{array}$ & $\begin{array}{c}10-30 \\
\mathrm{~cm}\end{array}$ & $\begin{array}{c}0-30 \\
\mathrm{~cm}\end{array}$ \\
\hline & \multicolumn{3}{|c|}{ Number of } & \multicolumn{3}{|c|}{ Weight of } & \multicolumn{3}{|c|}{ Weight of roots } \\
\hline
\end{tabular}

TABLE 5. Mean weights of shoots and roots of Carsten VI winterwheat on parcel $D 22$ in 1957, in $\mathrm{mg}$ dry matter per $10 \mathrm{~cm}$ length of row. 


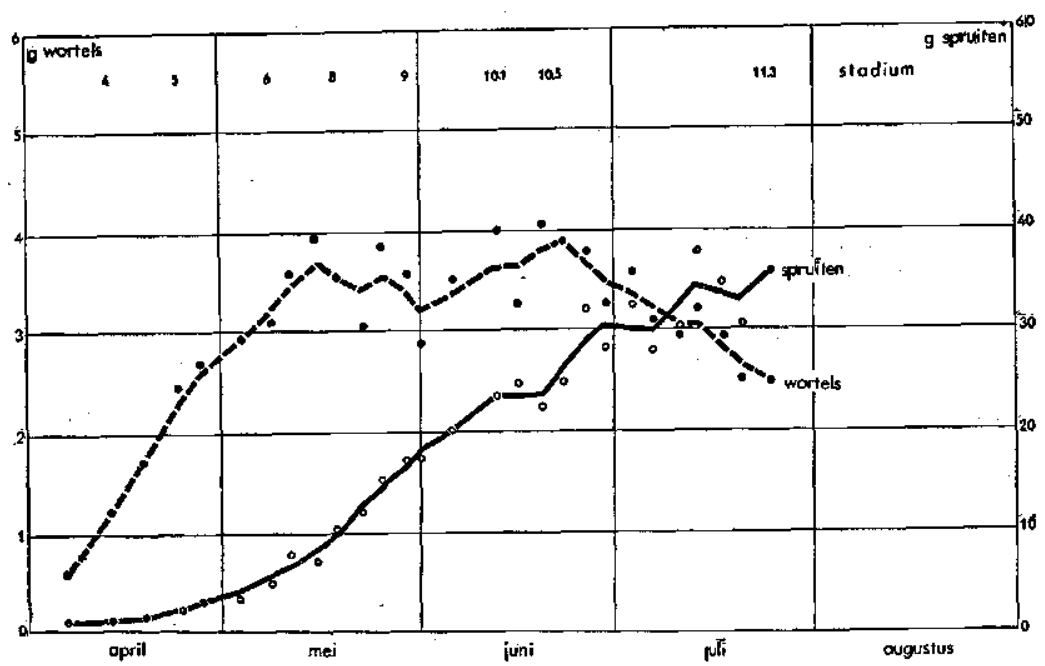

Fig. 6. Hoeveelheden (g droge stof) wortels en spruiten (halmen) van de wintertarwe op kavel $D 22$, op achtereenvolgende data in 1957, volgens tabel 5 .

Amounts ( $g$ dry matter) of roots and tops of winter wheat on parcel $D 22$, on succeeding dates in 1957, according to table 5.

Tweemaal per week werd het gewas bemonsterd, n.l. op woensdag en zaterdag. $\mathrm{Na}$ het bemonsteren werd het aan dezelfde behandelingen onderworpen als bij het onderzoek van de wintertarwe op kavel $Q 110$. Van het bovengrondse gedeelte werd het aantal planten en het aantal spruiten geteld. Toen de planten begonnen te schieten (11 mei) werd het mogelijk een onderscheid te maken tussen de spruiten die wel en die geen halm vormden. Deze werden apart geteld en na 1 juni ook apart gewogen. In deze periode wordt het aantal planten zowel als het aantal spruiten per $10 \mathrm{~cm}$ rijlengte geringer. Ofschoon het toeval hier een rol kan spelen, is een zekere daling van het aantal planten en spruiten niet uitgesloten.

Tabel 5 geeft een overzicht van de aantallen en gewichten der spruiten per $10 \mathrm{~cm}$ rijlengte (een vierde gedeelte van hetgeen per bemonstering op de naaldenplank aanwezig was), en het totale gewicht der wortels in de laag van $0-30 \mathrm{~cm}$, eveneens van $10 \mathrm{~cm}$ rijlengte. Door de wijze van monster nemen behoefde geen omrekening plaats te vinden.

Figuur 6 geeft een beeld van het verloop der gewichten van de boven- en ondergrondse delen.

Zowel uit de tabellen als uit de figuren blijkt er een redelijke overeenstemming te bestaan tussen de ontwikkeling van de wintertarwe in 1956 en die van 1957. Dit treft te meer, omdat er reële verschillen in klimaat, grondsoort en ras aanwezig zijn. 


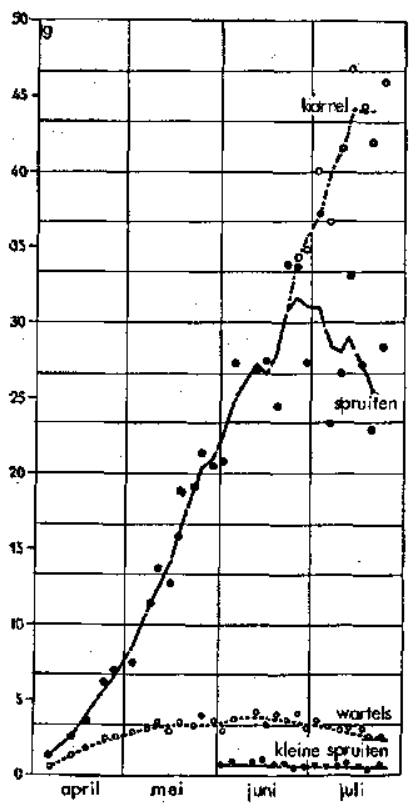

Fig. 7. Hoeveelheden (g droge stof) wortels, grote en kleine spruiten en korrel vas de wintertarwe op kavel D 22, op ach. tereenvolgende data, volgens tabel 5 .

Amounts ( $g$ dry matter) of roots, big and small tillers and seed of winter wheat on parcel $D 22$, on succeeding dates in 1957, according to table 5.

De overeenkomst in het verloop van de wortelhoeveelheden bestaat in de snelle toeneming van de hoeveelheid wortels tot het begin van de pseudo-stengelvorming en in de versnelde toeneming tot het te voorschijn komen van het schotblad. Tussen het in schotblad komen en het in de aar komen is het onzeker, of de wortelhoeveelheid afneemt dan wel ongeveer gelijk blijft. Daarna is er nog enige toeneming tot het gewas in bloei staat en daarop volgt een langzame achteruitgang van de hoeveelheid wortels.

De spreiding van de hoeveelheid wortels tussen de opvolgende data is nogal groot. Hieraan behoeft geen betekenis te worden toegekend, indien wordt aangenomen dat bij de korte intervallen van 3 of 4 dagen dergelijke schommelingen in de wortelhoeveelheid van dezelfde toevallige aard zijn als het geval is bij duplobepalingen op dezelfde tijd.

De ontwikkeling van de bovengrondse delen komt in beide jaren ook grotendeels overeen. De aanvankelijk langzame toeneming wordt sneller tijdens het begin van de stengelvorming en verloopt daarna enigszins golvend tot het eind van de rijping. Het is ook hier het eenvoudigst om deze golvingen als toevalligheden te verklaren.

In figuur 7 , betreffende de bovengrondse ontwikkeling van de wintertarwe op kavel D 22 in 1957, zijn de massa's per $10 \mathrm{~cm}$ rijlengte verdeeld in kleine (achtergebleven) spruiten, normale halmen en de korrels.

Wegens de grote schommelingen in de halmgewichten op de opeen- 
volgende bemonsteringsdata zijn deze in de grafiek eerst vereffend, waarna de korrelgewichten gesommeerd zijn op deze vereffende halmgewichten.

Het resultaat is een van het begin tot het eind vrij regelmatig stijgende lijn.

\section{f. Samenvatting}

$\mathrm{Na}$ de kieming in het najaar komen de kiemwortels tot ontwikkeling. Onder gunstige omstandigheden (vroege zaai, zachte herfst) kunnen zij reeds voor de winter een vrij grote diepte bereiken. Met het begin van de uitstoeling valt het te voorschijn komen van de kroonwortels samen. Deze kroonwortels reiken in het najaar in het algemeen niet dieper dan de bouwvoor.

Tijdens de winter is er van wortelgroei weinig te bespeuren. In het voorjaar neemt de wortelgroei en nieuwvorming sterk toe. Omstreeks het begin van de stengelvorming heeft het wortelstelsel zijn grootste omvang bereikt. Het blijft enige tijd constant en begint na de korrelzetting achteruit te gaan. Deze achteruitgang vindt hoofdzakelijk plaats in de bouwvoor. In de ondergrond zijn de veranderingen in wortelhoeveelheid gering, nadat de voorjaarsgroei is begonnen.

\section{Winterrogge}

Dit gewas wordt in de Noordoostpolder weinig verbouwd. Het komt niet voor op de homogene zavelprofielen. De beworteling werd onderzocht in verschillende zandprofielen en eenmaal in een profiel van zavel-op-zand.

Het kiemwortelstelsel is reeds voor de winter voltooid. De uitstoeling en de vorming van de kroonwortels begonnen ook reeds voor de winter. Dit gedrag wijkt niet af van dat van wintertarwe. De rogge wordt echter in de regel vroeger gezaaid en groeit bij lagere temperatuur door, en heeft daardoor meer gelegenheid om te groeien.

In het voorjaar begint de groei eerder dan bij wintertarwe, met als gevolg dat het kroonwortelstelsel 2 à 4 weken vroeger zijn grootste omvang bereikt. De achteruitgang begint reeds duidelijk merkbaar te worden in het einde van juli, dus vroeger dan bij wintertarwe. De zijwortelvorming lijkt intensiever te zijn dan van wintertarwe. Het is echter de vraag, of dit een eigenschap is van het gewas of een door de grond veroorzaakt verschijnsel. Ook bij andere granen werd waargenomen, dat in zandige grond de zijwortelontwikkeling sterker was. Een vergelijking met de andere granen is moeilijk, omdat op zavel de rogge niet voorkomt.

Van een vergelijking der wortelstelsels op kavel S 37 in 1951 is bekend, dat de wortelontwikkeling van de winterrogge geringer was dan die van wintertarwe. Wegens het verschil in groeistadium (de rogge was geoogst en de tarwe nog groen) is het beeld niet juist. Van de-rogge was de wortelhoeveelheid vermoedelijk al achteruitgegaan. 


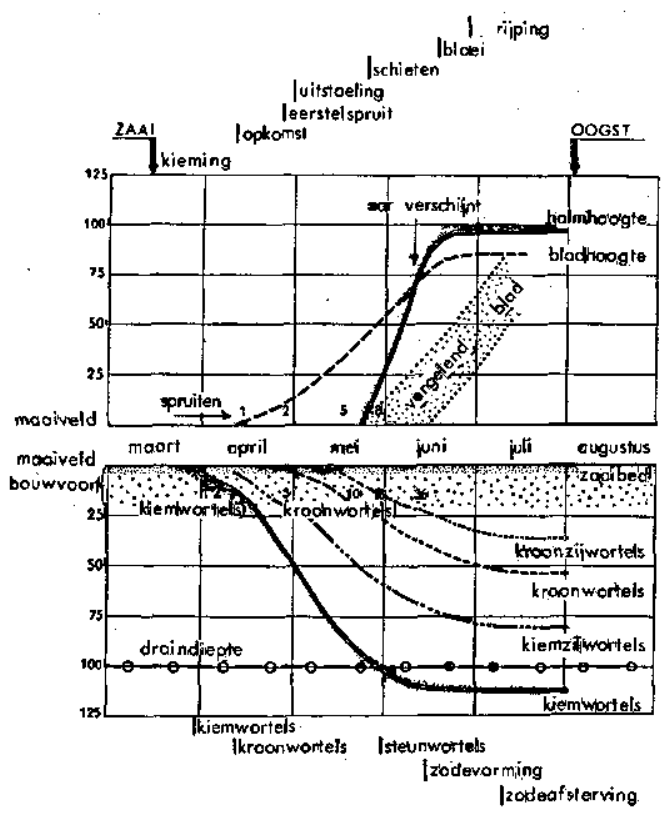

Fig. 8. Schema van de bovenen ondergrondse ontwikkeling van zomergerst.

Diagram of the development of tops and roots of spring barley.

WEAVER vermeldt, dat winterrogge een sterker vertakt wortelstelsel heeft dan wintertarwe, en haalt een onderzoek van Nobbe aan, waaruit dit eveneens blijkt.

\section{Zomergerst}

De ontwikkeling van zomergerst (fig. 8) is als voorbeeld gekozen voor de ontwikkeling van de wortels der zomergranen.

Op gelijke wijze als bij de wintertarwe is de boven- en ondergrondse ontwikkeling schematisch in tekening gebracht. Het belangrijkste verschil is het ontbreken van de winterrustperiode. Na de kieming gaat de gehele ontwikkeling in een ruk door. Zomergerst rijpt het vroegst af van de zomergranen en is ook eerder rijp dan wintertarwe. Dit heeft tot gevolg dat het schema een samengedrukt karakter heeft. De groeiperiode van de zomergerst bedraagt ongeveer de helft van die van wintertarwe.

\section{a. De kiemwortels}

Het aantal is wat groter dan bij wintertarwe. $\mathrm{Zij}$ spreiden zich van het begin af iets wijder uit en beginnen zeer spoedig met zijwortelvorming. Lange eerste-graads zijwortels treden op bij de basis van de kiem. 
zelfde bruine uiterlijk dat bij de kiemkorrels van wintertarwe gedurende de winterrust optreedt.

In de bouwvoor en soms in de ondergrond worden tweede-graads zijwortels gevormd.

\section{b. De kroonwortels}

Bij het begin van de uitstoeling hebben de kiemwortels reeds een diepte van $\pm 50 \mathrm{~cm}$ bereikt. De kroonwortelvorming begint op dit tijdstip. Het aantal neemt regelmatig toe, maar bereikt niet de omvang als bij wintertarwe. De uitstoelingsperiode is betrekkelijk kort en het aantal spruiten niet groot. Het geringere aantal kroonwortels kan hiermee samenhangen. In de bouwvoor komen tweede-graads zijwortels voor. Een enkele maal zijn in de zodelaag derde-graads vertakkingen gevonden.

$\mathrm{Na}$ de halmvorming gaat de kroonwortelvorming door met het ontstaan van de "tuien". De achteruitgang tijdens het rijpen begint in de zodelaag, net als bij wintertarwe.

6. Samenvatting van de wortelontwikkeling der granen

a. De kiemwortels

De kiemwortels komen het eerst te voorschijn. Het aantal is afhankelijk van de soort van het gewas.

De kiemwortels vertonen een betrekkelijk snelle dieptegroei, met een geringe horizontale spreiding. $\mathrm{Zij}$ kunnen een groot aantal zijwortels vormen.

\section{b. De kroonwortels}

Deze worden, behalve bij haver, gevormd op het tijdstip dat de uitstoeling begint. Er bestaat een samenhang tussen het aantal gevormde spruiten en het aantal kroonwortels. De vertakking van de kroonwortels in de bouwvoor is vaak sterker dan in de ondergrond. De fijnste vertakkingen kunnen een dicht wortelnet in de bovenlaag van de bouwvoor vormen. Dit wordt aangeduid met zodevorming.

$\mathrm{Na}$ het schieten wordt nog een aantal kroonwortels gevormd die meer zijwaarts groeien en weinig of niet vertakt zijn. In overeenstemming met de "verankerende" functie die GOEDEwaAGEN aan deze wortels toe-
kent, worden ze ,tuien" genoemd.

De eerst gevormde kroonwortels kunnen een grote diepte bereiken, maar gaan vermoedelijk niet zo diep als de kiemwortels. De dieptegroei van de later ontstane kroonwortels is in het algemeen veel geringer. De sterk verhoutende tuien komen niet veel dieper dan de bouwvoor. voor.

\section{c. De zodelaag}

De kiemwortels dragen niet bij aan de intensieve doorworteling van de bouwvoor, daar zij recht naar beneden groeien en met hun zijwortels 
slechts een beperkte horizontale uitbreiding krijgen. Met de vorming van de kroonwortels begint pas de doorworteling van de bouwvoor.

In het bovenste laagje van de bouwvoor wordt een dicht net gevormd door fijne zijwortels. Het ontstaan en bestaan hiervan wordt beïnvloed o.a. door de vochtigheid van de grond. In een droog en schraal voorjaar blijft het achterwege, om pas na regenval en temperatuursstijging tot ontwikkeling te komen. In het algemeen kon echter worden opgemerkt, dat de doorworteling binnen enkele weken na de aanvang van hernieuwde groei of nieuwvorming van kroonwortels tot stand kwam. Afhankelijk van de vochtigheid, is het zodelaagje min of meer dicht. Beschadiging door verplegingswerkzaamheden werd waargenomen. Het herstel verliep in de regel zeer vlug, zodat van enige invloed op de groei van het gewas niets werd gemerkt.

\section{TweezaAdlobbige LandbouWgewassen}

De wortelontwikkeling van de dicotyle planten is gekenmerkt door de vorming van één hoofdwortel (penwortel), welke een meer of minder groot aantal zijwortels kan vormen, die op hun beurt ook weer zijwortels kunnen vormen. Het wortelbeeld van de tot deze groep behorende planten wijkt onderling veel sterker af dan bij de monocotylen (granen), die in het voorgaande zijn behandeld. Dit geldt ook voor de gewassen die tot een zelfde familie behoren. Daartegenover staat, dat de wortelbeelden van de verschillende families ten opzichte van elkaar nog grotere verschillen tonen. Zo is er een zekere overeenkomst tussen koolzaad, gele mosterd en dederzaad en eveneens tussen erwten en bonen.

Witte en rode klaver tonen enige overeenkomst; luzerne en hopperups klaver wijken echter sterk af. Blauwmaanzaad, bieten en vlas verschillen zowel van elkaar als van de genoemde gewassen.

Door de verschillen is het gemakkelijker de dicotyle gewassen aan hun wortelbeeld te herkennen dan de granen. De enige overeenkomst met granen is, dat de dicotyle gewassen vrij snel zowel in horizontale als in verticale richting een homogeen zavelprofiel kunnen doorwortelen tot een diepte van $\pm 100 \mathrm{~cm}$.

Over verdere dieptegroei is in de Noordoostpolder weinig bekend, omdat de ongeaëreerde toestand van het profiel op grotere diepte geen beworteling toelaat.

\section{Winterkoolzaad}

Winterkoolzaad is gekozen als voorbeeld voor een overwinterende dicotyle plant (fig.9).

De bij de kieming gevormde hoofdwortel kan in de herfst reeds een grote diepte bereiken. Onder gunstige omstandigheden, zoals vroege zaai en een homogeen profiel, bereikt deze wortel een diepte van $75 \mathrm{~cm}$. In de bouwvoor is deze hoofdwortel verdikt (fig. 23). Indien de hoofd- 


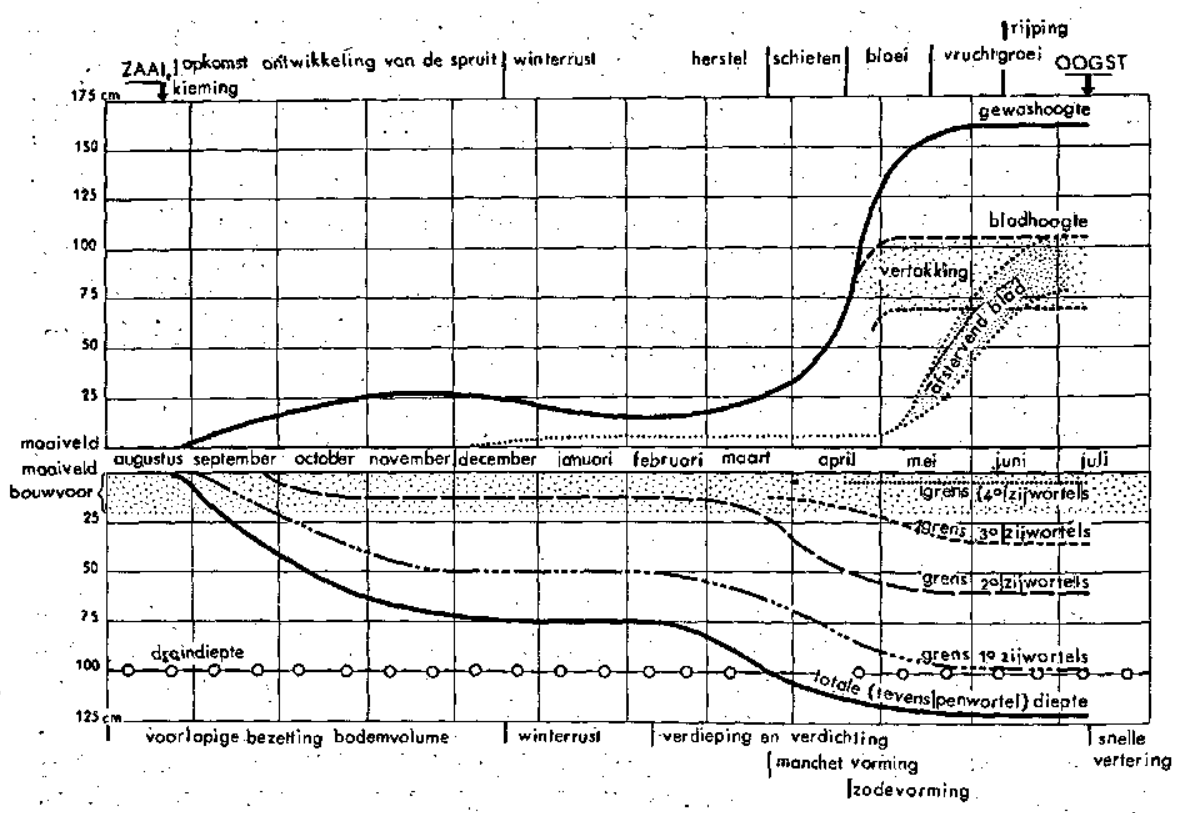

Fig. 9. Scheina van de boven- en ondergrondse ontwikkeling van winterkoolzaad. Diagram of the development of tops and roots of winter swede rape.

wortel diep kan groeien, blijft hij slanker dan wanneer de dieptegroei verhinderd wordt. Ditzelfde geldt voor de zijwortels. Zij staan in twee rijen tegenover elkaar ingeplant, doorwortelen echter de gehele ruimte onder de plant. Bij een korte penwortel worden ze nogal dik en fors, bij een lange penwortel blijven zij dun. Het aantal gevormde zijwortels neemt van boven naar beneden af, evenals de lengte.

Tijdens de winter staat de wortelgroei stil. Daarna begint de groei echter vroeg. Halverwege maart tot begin april wordt de grootste diepte reeds bereikt (d.w.z. $\pm 100 \mathrm{~cm}$ ). De hoofdwortel groeit dus door. Indien hij is afgerot door te grote natheid van de grond, nermen een of meer zijwortels de taak over. Dit is zeer duidelijk, indien de hoofdwortel tot in de bouwvoor is afgestorven.

De zijwortelvorming is intensief. In de herfst werden tweede-graads zijwortels aangetroffen. In het voorjaar kwamen in de bouwvoor ook vierde-graads zijwortels voor, vnl. in de bovenste laag, waar evenals bij de granen, een zodelaagje werd gevormd. In de bouwvoor komen verder derde-graads zijwortels voor en in de ondergrond tweede-graads zijwortels.

Een merkwaardig verschijnsel in het voorjaar is de vorming van een zeer groot aantal dunne zijwortels, ontspringende uit de overwinterd hebbende wortels. Hoofd- en zijwortels zijn dan omgeven door een dichte laag dunne worteltjes. Deze geven aan de wortels het uiterlijk alsof er. 
een manchet omheen zit. Deze manchetvorming begint zeer vroeg (fig. 25).

De horizontale uitbreiding van de wortels kan groot zijn. Door de verbouw in rijen wordt zij echter in zekere mate beperkt. In de bouwvoor werden zijwortels gevonden tot op $55 \mathrm{~cm}$ afstand van de plant (fig. 24).

Er werd reeds op gewezen, dat de hernieuwe groei in het voorjaar vroeg begint. Dit geldt ook voor het bovengrondse gedeelte. De dieptegroei blijft echter voor bij de hoogtegroei. In fig. 9 is dit aàngegeven. $\mathrm{Na}$ de bloei begint de wortelhoeveelheid in de bouwvoor te verminderen. Het zodelaagje, dat zeer gevoelig voor droogte is, sterft soms gedurende de droge periode in juni reeds af. Nieuwvorming na regen treedt vaak op.

De wortels van het rijpe gewas verteren snel. Dit kan een eigenschap van het gewas zijn. De weersomstandigheden (warmte) die over het algemeen in de oogstperiode van koolzaad heersen, zijn natuurlijk gunstig voor de vertering.

\section{Suikerbieten}

De groei van dit gewas, waarvan de beschrijving slechts betrekking heeft op het eerste jaar, mag als tegenstelling tot die van winterkoolzaad gelden, welke laatste in herfst en voorjaar alle fasen van kieming, bloei en rijping snel doorloopt.

De suikerbiet wordt later dan de meeste andere gewassen gezaaid en heeft in het eerste jaar geen eindpunt in de groei dat duidelijk omschreven is. Indien het niet gaat vriezen, groeit de plant door. Het gelijkmatige doorgroeien van het bovengrondse gedeelte vindt zijn afspiegeling in het doorgroeien van het ondergrondse gedeelte. Er is geen tijd van de grootste uitbreiding, zoals bij de granen, en evenmin een achteruitgang na een bepaald groeistadium van de plant. Figuur I0 geeft de ontwikkeling van de suikerbiet schematisch weer.

Het bij de kieming te voorschijn komende penworteltje is zeer teer. Het groeit evenwel snel en bereikt in hetzelfde tempo als dat van de andere gewassen, maar op een later tijdstip, de draindiepte. Profiterende van de langere groeiperiode, komt de hoofdwortel van de suikerbiet het diepst van alle gewassen. Onder gunstige omstandigheden werd de hoofdwortel op $125 \mathrm{~cm}$ diepte aangetroffen. Dit is een limiet in de Noordoostpolder. In andere profielen worden uiteraard nog wel grotere diepten bereikt.

Spoedig na de opkomst worden de eerste zijworteltjes gevormd, als de penwortel nog maar $5 \mathrm{~cm}$ lang is. In mei bereiken de zijwortels al spoedig een lengte van $15 \mathrm{~cm}$ en eind mei kan de ruimte tussen en in de rijen reeds geheel doorworteld zijn. Görbing vermeldt, dat de zijwortels reeds de hele oppervlakte tussen de planten innemen voordat de grond volledig door de bladeren is bedekt (fig. 26 en 27). 


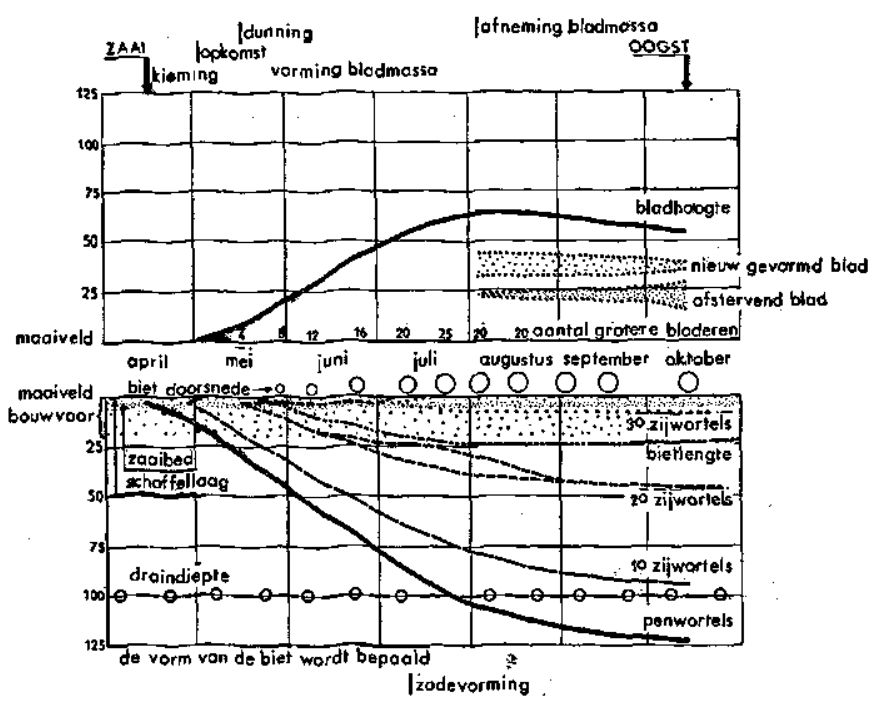

Fig. 10. Schema van de boven- en ondergrondse ontwikkeling van suikerbieten.

Diagram of the development of tops and roots of sugar beet.

Evenals bij het winterkoolzaad ontspringen de zijwortels in twee tegenover elkaar liggende rijen en ook bij de suikerbiet heeft dit geen invloed op de horizontale verspreiding.

De diktegroei van de penwortel begint bij de vorming van de echte bladeren en wordt ingeleid met het barsten van het kraagje dat wordt gevormd door de voeten van de kiemblaadjes. De lengte waarover de diktegroei plaatsvindt, wordt (behalve door de erfelijke eigenschappen van de plant) beïnvloed door de structuur van de grond. Het lijkt waarschijnlijk, dat het niet zozeer de vastheid van de grond is, die de vorm van de bieten bepaalt, als wel de verdeling van de vastheid. Bij een tot op enige diepte gelijkmatige losheid van de grond kunnen zeer lange bieten ontstaan, zodat de overgang van de biet naar de penwortel moeilijk is aan te geven. Bij een losse bovenlaag en een vaste onderlaag van de bouwvoor kunnen de bieten een korte ingeknepen vorm krijgen. Vaak treedt dan ook een sterke ontwikkeling van de zijwortels op. In hoofdstuk $\mathrm{V}$ wordt gewezen op de drie typische vormen, die bij de suikerbieten algemeen werden opgemerkt. Het voorkomen van deze vormen wordt grotendeels verklaard uit de vastheid van de grond.

Volgens GLIEMEROTH (1953) wordt de ontwikkeling van zware zijwortels bevordert door de toediening van meststoffen aan de bovenste laag van de bouwvoor. Een gelijkmatige verdeling van de meststof door de gehele bouwvoor vermindert de zware zijwortelvorming. Ofschoon GuIEMERoTн vermeldt, dat de bewerking van de boven- en ondergrond van 
de bouwvoor gelijk was, maken de afbeeldingen van de suikerbieten zeer sterk de indruk, dat de zijwortelvorming bij oppervlakkig inwerken van de meststof het gevolg is van een storing in de structuur van de bouwvoor. Deze storing zou kunnen ontstaan zijn bij het oppervlakkig inwerken van de meststof.

Aan het eind van de groeiperiode bestaat het wortelstelsel uit de volgende delen:

a. De verdikte penwortel in de bouwvoor, welke (blijkbaar afhankelijk van de aard van de bouwvoor) bezet is met min of meer dikke zijwortels. Deze zijwortels zijn krachtiger ontwikkeld naarmate de groei in de ondergrond wordt gestoord.

b. De beworteling in de bouwvoor, met de zodelaag in het bovenste laagje. De wortels zijn in de bouwvoor gelijkmatig verdeeld. Het zodelaagje wordt uiteraard beïnvloed door de vochtigheid van de grond en door verplegingswerkzaamheden. Het herstellingsvermogen is zeer groot.

c. De beworteling in de ondergrond, gevormd door penwortel en zijwortels.

In de literatuur (WEAvER, GoEDEWAAGEN) wordt het wortelstelsel van de biet op de afbeeldingen vaak gekarakteriseerd door een dichte beworteling in de bouwvoor, een bijna zijwortelvrije zone op de hoogte van de overgang van de biet naar de penwortel en een sterke zijwortelvorming in de ondergrond. Dit typische beeld werd in de Noordoostpolder niet aangetroffen.

\section{Groene erwten, kapucijners en rozijnerwten}

De overeenkomst tussen de beworteling van deze gewassen is zo groot, dat het niet nodig is er onderscheid tussen te maken.

De penwortel, die bij deze gewassen (evenals bij de overige) eerder te voorschijn komt dan de eerste blaadjes, is dik en wit-vlezig, groeit snel en kan eind mei een diepte van $100 \mathrm{~cm}$ hebben bereikt. De erwtenwortels zijn teer, zodat zij bij het onderzoek in kuilwanden gemakkelijk breken en daardoor moeilijk zijn te volgen.

De eerste zijwortels ontstaan in het basale gedeelte van de hoofdwortel, als deze nog slechts $10 \mathrm{~cm}$ lang is. Het aantal is groot. Er zijn 10 tot 15 zijwortels per $\mathrm{cm}$ lengte gesteld. Zij komen rondom de stengel te voorschijn. De lengte van deze zijwortels is afhankelijk van hun ouderdom en hun oorsprong. Boven in de bouwvoor bleken de oudste zijwortels tot $30 \mathrm{~cm}$ lang te kunnen zijn, met een groeisnelheid van 1 à $2 \mathrm{~cm}$ per dag. Onder in de bouwvoor blijven zij korter. In uiterlijk gelijken zij op de hoofdwortel, omdat ze ook vrij dik zijn. Een overeenkomst met de kroonwortels der granen is, dat de bovenste zijwortels aanvankelijk bijna horizontaal groeien en op 15 à $20 \mathrm{~cm}$ van de plant ombuigen naar beneden. Deze bevindingen zijn geheel in overeenstemming met die van Kraus.

De zijwortels onder de bouwvoor blijven aanvankelijk kort; na half mei beginnen zij te groeien, zodat in juni de penwortel over de hele 
lengte van lange eerste-graads zijwortels is voorzien. Vorming van tweedegraads zijwortels vindt eveneens over de gehele diepte plaats. Verdere zijwortelvorming komt echter sporadisch voor (fig. 30).

De erwten vormen wortels aan het gedeelte dat zich tussen zaad en grondoppervlakte bevindt, dus aan de epicotyle as. Deze wortels kunnen zich sterk vertakken en dan een zodelaagje vormen. Dit gebeurt bij het begin van de bloei en is sterk afhankelijk van de vochtigheid van de bovenlaag. Nog tijdens de bloei begint het wortelstelsel te verkleuren, het wordt bruin-geel. Soms komt nog nieuwvorming voor, maar als het gewas begint te rijpen, gaat het wortelstelsel al achteruit. De zodelaag verdwijnt het eerst en na het oogsten -,verdwijnt" het gehele wortelstelsel in een paar weken.

De door bacteriën veroorzaakte wortelknolletjes werden op alle wortels aangetroffen. Het eerst op de hoofdwortel, later: op de zijwortels. Vooral werden ze aangetroffen in scheuren en holten in de grond. De grootste diepte waarop zij bij erwten werden gevonden, bedroeg $50 \mathrm{~cm}$ onder de oppervlakte.

\section{Vlas}

Het wortelstelsel van het vlas is in bouw vrijwel gelijk aan dat van de erwt. Het wortelbeeld verschilt. De erwt heeft een grof en vrij ijl, vlas een fijn en vrij dicht wortelstelsel, dat opvallend wit tot lichtgeel is gekleurd. In hoeverre de gebruikelijke zeer dichte stand van dit'gewas de bewortelingsdichtheid beïnvloedt, is niet bekend. De afbeelding die GoedewaAgen (1942) geeft van een jonge vlasplant, doet vermoeden, dat ook bij een ruime standwijdte vlas een dichte beworteling heeft.

De penwortel groeit snel. In 13 dagen werd een dieptegroei van $40 \mathrm{~cm}$ waargenomen. Het gewas dat toen in de grond een diepte van $50 \mathrm{~cm}$ had, was boven de grond slechts $6 \mathrm{~cm}$ lang (half april). Eind mei werd een diepte van $100 \mathrm{~cm}$ bereikt (fig. 29).

De ontwikkeling van eerste-, tweede- en derde-graads zijwortels geschiedt op overeenkomstige wijze als bij de erwten.

Stengelwortels worden bijna niet gevormd.

Tegen de rijping begint de achteruitgang van de wortels in de bovenste laag. De vertering in de ondergrond gaat langzaam. Bij de oogst zijn de wortels in de ondergrond nog goed.

\section{Luzerne}

Door zijn vaak lange en stevige penwortel lijkt luzerne een zeer aparte plaats in te nemen in het geheel van de wortelbeelden der landbouwgewassen (fig. 32). Op grond van deze verschijningsvorm worden vaak aan de luzernewortels eigenschappen toegeschreven die zij in werkelijk-
heid missen.

Waarschijnlijk indachtig het feit; dat een dikke heiningpaal sterker is dan een dunne, wordt verondersteld, dat de dikke penwortel van 
luzerne beter in de grond kan dringen dan de dunne penwortels van andere gewassen. De ontwikkeling van de luzernewortels is echter gelijk aan die van de tweezaadlobbigen.

Bij de kieming komt de hoofdwortel te voorschijn, welke blijft groeien tot de weersomstandigheden dit niet meer toelaten. Geheel vergelijkbaar met de suikerbiet. Als hoofdgewas gezaaid (dus niet onder dekvrucht) kan de penwortel het eerste jaar tot beneden draindiepte komen $(125 \mathrm{~cm})$, indien de grond dit toelaat.

De worteltop is teer en gevoelig voor ongunstige bodemtoestanden. Kan zij niet verder groeien, dan treedt versterkte zijwortelvorming dicht bij de top op. Deze zijwortels groeien aanvankelijk schuin zijwaarts, om daarna de penwortel te vervangen.

Over het algemeen is de zijwortelvorming echter niet sterk. In de bouwvoor is ze zelfs vrij $\mathrm{ijl}$, vergeleken met andere gewassen. Aan een lange penwortel worden weinig zijwortels gevormd (fig. 33). Blijft de penwortel om enige reden kort, dan komen vaak zware zijwortels voor, die ook dan slechts enkele dunne zijwortels dragen. WEAVER beschrijtt ditzelfde verschijnsel en demonstreert het ook met een foto.

De zijwortels zijn bij de oorsprong iets omhoog gericht; ze buigen echter spoedig om en groeien omlaag.

Zodevorming vindt weinig plaats, vermoedelijk omdat de structuur van de bovenste laag in de regel nogal slecht is. Deze slechte structuur wordt veroorzaakt door het berijden bij de oogstwerkzaamheden, welke bij een overjarig luzernegewas drie- tot vijfmaal hebben plaatsgevonden.

Het herstellingsvermogen van de penwortel is groot. Verscheidene malen werd waargenomen, dat een tot op $5 \mathrm{~cm}$ lengte afgestorven wortel in het voorjaar vrij spoedig haar vroegere diepte bereikte door vorming van een nieuwe top op de plaats van afsterving.

De wortels zijn gevoelig voor wateroverlast. Het begint met een blauw-zwarte verkleuring aan de buitenkant, gevolgd door sterven van de wortel over het gedeelte dat verkleurd is.

De beworteling van luzerne reageert net als de andere wortels op structuurverschillen in de bodem. De blijvende penwortel, die bovendien met het ouder worden van het gewas dikker wordt, is een zeer plezierige verschijning bij de beoordeling van de profielen, omdat hij zo goed zichtbaar is. Door de grotere dikte en stevigheid zijn de afwijkingen ook beter zichtbaar en blijven ze dit, ook nadat de wortels uit de grond zijn verwijderd.

Evenals bij de erwten zijn de wortels van luzerne bezet met wortelknolletjes. Het eerste jaar vaak sterker dan het tweede jaar. De hoeveelheid neemt af met de toenemende diepte. In de ondergrond wordt de plaats ervan vnl. bepaald door de aanwezigheid van scheuren en holten. Tot op $50 \mathrm{~cm}$ diepte werden de knolletjes regelmatig gevonden, soms nog dieper.

De ontwikkeling der wortels wordt beïnvloed door de ouderdom en de omstandigheden waaronder het gewas gegroeid is, zoals met of zonder dekvrucht (fig. 31). 
Ten opzichte van luzerne is de penwortel van rode klaver veel minder ontwikkeld; de zijwortelvorming is echter veel sterker.

De hoofdwortel van hopperups-klaver is onaanzienlijk; de beworteling in de bouwvoor schijnt vnl. uit zijwortels te bestaan. Het aantal zijwortels is te vergelijken met het aantal wortels van een graszode.

6. Samenvatting van de wortelontwikkeling der tweezaadlobbigen

a. De penwortel

De tweezaadlobbigen vormen bij het kiemen een hoofdwortel, ook penwortel genoemd. Deze groeit recht naar beneden en kan in betrekkelijk korte tijd (2 à 3 maanden) een diepte bereiken van $\pm 100 \mathrm{~cm}$.

De penwortel reikt in de regel tot halverwege de bouwvoor op het tijdstip dat de kiemblaadjes boven de grond komen.

De penwortels der verschillende gewassen zijn van elkaar te onderscheiden door hun vorm, dikte en kleur.

$\mathrm{Bij}$ overwinterende gewassen blijft de penwortel bestaan. Het is niet duidelijk, in hoeverre na de winter de penwortel weer gaat groeien. Dit hangt af van de reeds bereikte diepte en de mogelijkheid die het profiel biedt om verder te groeien. De sterke zijwortelvorming na de winter laat niet altijd toe de hoofd- van de zijwortels te onderscheiden.

b. De zijwortels

De zijwortelvorming begint in de regel vroeg, ongeveer gelijktijdig met het boven de grond komen van de kiembladeren. De mate van de verdere zijwortelvorming (tweede-, derde- en soms vierde-graad) wordt bepaald door de diepte. In de bouwvoor is zij het sterkst, naar beneden wordt zij minder. De meeste gewassen kunnen in de bovenlaag van de bouwvoor een dicht net van fijne zijwortels vormen, de zodelaag.

Indien de hoofdwortel niet volledig tot ontwikkeling kan komen, worden de zijwortels zwaarder. Bij gewassen als bieten, koolzaad en luzerne kunnen deze zijwortels geheel het karakter krijgen van de hoofdwortel. 


\section{DE ONTWIKKELING VAN HET WORTELSTELSEL IN DE VERSCHILLENDE GRONDSOORTEN}

In het voorgaande hoofdstuk werd de beworteling van een aantal gewassen beschreven in een homogeen zavelprofiel. Dit homogene zavelprofiel werd gekarakteriseerd door de afwezigheid van lagen met een andere samenstelling dan zavel, een tot $\pm 100 \mathrm{~cm}$ diepte gevorderde rijping en een zomer-grondwaterstand van $\pm 150 \mathrm{~cm}$ beneden maaiveld.

Een afwijkend profiel betekent in dit verband dus het voorkomen van lagen met een granulaire samenstelling die afwijkt van die van zavel, het tot onvoldoende diepte gerijpt zijn of een te hoge grondwaterstand. Deze factoren behoeven niet gelijktijdig aanwezig te zijn. Er bestaat evenwel de mogelijkheid van een samengaan.

Zowel de rijping als de grondwaterstand kunnen worden beïnvloed door de aard van de het profiel samenstellende lagen.

Achtereenvolgens zullen de invloed van de rijping en de samenstelling van de lagen worden behandeld.

\section{De invloed van de rijping}

De veranderingen die nodig zijn om de pas drooggevallen polderbodem geschikt te doen worden voor de groei van landplanten, worden samengevat in het begrip rijping. Het is een geheel van physische, chemische en microbiologische processen, welke de oorspronkelijk met water verzadigde, donker gekleurde afzettingen doen veranderen in een bodem die geschikt is voor plantengroei. Voor een beschrijving van dit gebeuren wordt verwezen naar Domingo, ZuUR en VAN Schreven.

De belangrijkste uiterlijke verschijnselen zijn het droger worden van de bodem en een kleurverandering van donkerblauw tot grijs of bruin.

Het verdwijnen van een gedeelte van het water heeft tot gevolg, dat de zwaardere gronden sterk gaan scheuren. Lichtere gronden scheuren weinig of niet, doch verliezen wel water. In beide gevallen dringt lucht door in de poriën waaruit het water is verdwenen. Door de in de lucht aanwezige zuurstof kunnen verschillende stoffen (sulfiden) oxyderen, hetgeen de kleurverandering tot gevolg heeft. Het indrogingsproces is gedeeltelijk irreversibel, het oxydatieproces kan omgekeerd worden (namelijk indien voldoende organisch materiaal aanwezig is).

$\mathrm{Bij}$ het voortschrijden van het indrogingsproces gaat de scheurvorming door, met als einde een verkruimeling van de grond. De mate van 
de verdeling (door Jongerius fragmentatie genoemd) is afhankelijk van de diepte. Aan de oppervlakte ontstaan kruimels, in de ondergrond slechts grote scheuren. De zwaarte van de grond speelt hierbij een belangrijke rol.

De vordering van het rijpingsproces in de grond werd bij het bewortelingsonderzoek uitsluitend beoordeeld aan de blauwe kleuring. Het verdwijnen van de blauwe kleur is afhankelijk van de omzetting van sulfiden in sulfaten. Indien de oplosbare sulfaten uit het profiel verdwijnen en dus een reductie in het profiel door blauwkleuring niet waarneembaar is, geeft de kleur van het profiel geen inlichtingen over de zuurstofvoorziening. Dit onderdeel van de rijping, dat bepaald wordt door de luchttoetreding in de bodem, wordt aëratie genoemd.

In zavel levert dit geen moeilijkheden, omdat de blauwe kleur hierin goed waarneembaar is.

In zand is de blauwe kleur zeer licht en niet altijd goed te onderscheiden in een nat profel.

Autochtoon veen is geel-groen-bruin in ongerijpte toestand, na luchttoetreding zwart.

Het niet autochtone veen (vaak nog gemengd met een zekere hoeveelheid minerale delen) is in ongerijpte toestand zwart en verkleurt niet na de toetreding van lucht.

In de zandgronden is een beoordeling van de aëratie aan de hand van de ontkleuring moeilijk. De hoeveelheid sulfiden is gering, de mogelijkheid van uitspoeling is groot. Het ontkleuringsproces verloopt met de tijd van boven naar beneden. Indien op een zeker tijdstip de grens van ontkleuring op b.v. $60 \mathrm{~cm}$ diepte ligt, wordi aangenomen dat alles daarboven geaëreerd is. In een begroeid zandprofiel kan in een natte tijd vaak een blauwkleuring in de zodelaag worden waargenomen, terwijl de ondergrond geen spoor van blauwkleuring vertoont. De blauwkleuring in de zodelaag wordt dan veroorzaakt door de reductieverschijnselen bij de ontleding van organische stof. De afwezigheid van blauwkleuring in de ondergrond laat in dit geval geen conclusie toe over de zuurstofvoorziening daar ter plaatse. De afwezigheid kan n.l. berusten op voldoende zuurstof en/of de afwezigheid van reduceerbaar materiaal.

$\mathrm{Bij}$ de beschrijving van de beworteling in zandlagen wordt hierop teruggekomen.

$\mathrm{Bij}$ de aëratie zijn in een profiel drie zones te onderscheiden. Van boven naar beneden achtereenvolgens een volledig geaëreerde laag, een laag waarin gedeeltelijk wel en gedeeltelijk niet geaëreerde plekken voorkomen en een nog niet geaëreerde laag.

Wortels worden bijna uitsluitend in de geaëreerde grond aangetroffen, zodat de bewortelingsdiepte meestal wordt bepaald door de vordering van de aëratie.

Indien de wortels deze grens niet hebben bereikt, kan dit zijn omdat zij er nog niet aan toe zijn gekomen (dus nog te jong zijn) of omdat er een andere storende invloed aanwezig is. 
Indien de wortels wel in de ongeaëreerde lagen dringen, kan dit zijn omdat zij een oude wortelgang volgen, bij voorbeeld van riet, dat zeer goed in ongeaëreerde grond kan groeien.

Riet is, hoewel geen landbouwgewas in de gewone zin, een belangrijke plant in de nieuwe polder (BAKKER en BrEwINGA). De rietwortels kunnen zeer goed in de ongeaëreerde natte grond groeien, daar zij over luchtkanalen beschikken. Na het in cultuur nemen van de grond, als het riet is verdwenen, kunnen de wortels der gewassen de rietwortelgangen volgen.

Het is merkwaardig, dat, ondanks de uitgesproken voorkeur voor geaëreerde grond, toch bij alle gewassen wortels in de blauwe lagen werden aangetroffen, soms tot een lengte van $10 \mathrm{~cm}$. Dit verschijnsel werd echter alleen gevonden in lagen met een lutumgehalte hoger dan 10 à $12 \%$. Uiterlijk zijn deze wortels niet te onderscheiden van de overige. Na enige tijd wordt om deze wortels een enkele millimeters dik, bruin gekleurd, stevig laagje gevormd (aëratiekokertje), dat bij het uitspoelen der wortels heel blijft.

In de overgangszone van gerijpte naar ongerijpte grond wordt het begin van de rijping vaak gekenmerkt door scheurvorming. De scheurwanden hebben aanvankelijk een zeer dun aëratielaagje. Tegen de wanden wordt een wortelgordijn gevormd, dat door korte zijwortels en vermoedelijk ook wortelharen ermee is verbonden.

Daar de mogelijkheid van aëratie wordt bepaald door het verdwijnen van water, bevordert een begroeiing van de grond de rijping, omdat de planten water aan de grond onttrekken. Gedurende het groeiseizoen kan in een gedeeltelijk geaëreerde grond dit proces worden gevolgd.

$\mathrm{Zo}$ werd gedurende 1952 in verschillende gedeeltelijk geaëreerde profielen een verplaatsing van de aëratie-grens van $20 \mathrm{~cm}$ geconstateerd.

Het is te verwachten, dat een gewas met een lange groeiperiode meer water aan de grond zal onttrekken dan een gewas met een korte groeiperiode. Luzerne kan daarom de voorkeur genieten. Het is echter moeilijk om de invloed op de aëratie na te gaan. Daartoe dienen op eenzelfde perceel verschillende gewassen te worden verbouwd, op voldoende grote oppervlakte om geen randwerking te krijgen, en toch dicht genoeg bij elkaar om terreinverschillen te vermijden.

Op kavel S 37 kon in 1946 een vergelijking worden gemaakt ten aanzien van hun invloed op de aëratie tussen paardebonen en luzerne. Op. twee naast elkaar liggende vakken stonden in 1945 paardebonen en overjarige luzerne. In 1946 werd op deze vakken een aantal gewassen geteeld, zodanig dat deze op beide voorvruchten voorkwamen. Onder een vijftal gewassen werd de aëratie en de bewortelingsdiepte nagegaan, waarbij een verdeling in veldjes zonder en met stikstofbemesting werd toegepast. De gemiddelde cijfers van deze waarnemingen zijn als volgt: 
Aëratie en bewortelingsdiepte in $\mathrm{cm}$ beneden maaiveld

Voorvrucht

Stikstof

Volledig geaëreerd tot

Niet geaëreerd beneden

Bewortelingsdiepte

$\begin{array}{cc}\text { Paardebonen } \\ - & + \\ 48 & 53 \\ 68 & 77 \\ 54 & 62\end{array}$

Luzerne

$-+$

$57 \quad 59$

$80 \quad 75$

$7 \mathrm{I} \quad 70$

Deze beoordeling vond plaats na de oogst der gewassen, zodat de vermelde cijfers behalve door de voorvrucht ook door de gewassen zijn
beïnvloed.

Toch is een gunstige invloed van de luzerne aanwezig. Ook de invloed van een door stikstofbemesting zwaarder gewas blijkt uit de gegevens na voorvrucht paardebonen. Na voorvrucht luzerne is er geen verschil ten gevolge van stikstofbewerking. Dit behoeft geen verwondering te wekken, want in de gewassen was op dit gedeelte ook geen invloed van de stikstof waar te nemen.

In het algemeen is de wisselwerking tussen aëratie en beworteling zodanig, dat zij elkaar op de voet volgen; soms is de aëratie en soms is de beworteling iets voor.

Tussen de gewassen werden geen verschillen opgemerkt met betrek king tot de gevoeligheid voor de aëratietoestand van de grond.

De invloed van de samenstelling van de grond

Een laag wordt storend genoemd, indien de aanwezigheid ervan in een profiel tot gevolg heeft dat wortelstelsels in dat profiel afwijken van hetgeen in een homogeen zavelprofiel wordt waargenomen. De afwijking kan een meer of minder grote omvang aannemen, al naar de dikte in het profiel. kelijk zijp.

Het lijkt in de verschillenden overzicht te geven van het gedrag der wortels opgebouwd. Hierbij wordt de waaruit de Noordoostpolderbodem is naar jong. Voor de opbouw geologische indeling gevolgd van oud Wiggers en de Kaartbladen.

a. Keileem en glaciale zanden.

Hierover zijn geen voldoende gegevens aanwezig; zij worden practisch niet voor de landbouw gebruikt.

b. Het dekzand of laagterras

Het oudere, meer lemige en fijnzandige dekzand wordt niet doorworteld, omdat het meestal op grotere diepte en onder het jonge dekzand voorkomt. In het jonge dekzand is de beworteling schaars en traag, De Aaanwezig. Het gedrag in de A-horizont is normaal. 
De beworteling in de B-horizont is schaars en fijn, ook indien de A-horizont ontbreekt.

De wortels die nog door de A- en B-horizont groeien, blijven steken in de C-horizont. De aanwezige G-fibers zijn evenmin toegankelijk.

In de C-horizont eindigt de beworteling met trosvorming.

\section{c. Het veen}

In de Noordoostpolder komt binnen de voor doorworteling in aanmerking komende diepte voornamelijk riet-zeggeveen voor. Broekveen, oud en jong mosveen en spalterveen komen te weinig voor om er een bewortelingsbeeld van te geven.

In geaëreerde toestand is het riet-zeggeveen goed doorwortelbaar. In ongeaëreerde toestand is het nat. Toch worden er dan wel wortels in aangetrofien.

Bij de aëratie ontstaan scheuren waarin wortels voorkomen, echter in mindere mate dan bij dergelijke scheuren in zware zavel. De bewortelingsdichtheid in het veen komt overeen met die in zware zavel. Landbouwkundig ongunstige irreversibele indroging van het veen werd nog weinig aangetroffen. Waar het veen echter wel ongunstig indroogde werd het ontoegankelijk voor de wortels. De wortels groeiden wel tussen de ingedroogde aggregaten door, zodat de beworteling niet in de dieptegroei werd belemmerd.

Verslagen veen komt in zeer uiteenlopende vormen voor op het autochtone veen en is daar goed doorwortelbaar.

Op het dekzand komt grof verslagen veen, afgewisseld met laagjes grof zand, voor. Deze combinatie wordt niet doorworteld.

d. De oude zeeklei (Unio- en Cardiumklei en de kweldervorm van deze).

Deze klei komt voor over een beperkte oppervlakte in sectie $\mathrm{H}$, voornamelijk in de tweede halve meter in het profiel. $\mathrm{Ze}$ is bijna vrij van beworteling.

In de kwelderklei, (waaronder wordt verstaan het vroeger gerijpte en doorwortelde en doorgroeide gedeelte van de klei) vindt de beworteling hoofdzakelijk haar weg door oude wortelgangen.

\section{c. De detritus-gyttja}

Deze afzetting heeft een hoog humus- en lutumgehalte en komt in de ondergrond in een groot gedeelte van de Noordoostpolder voor. In het noorden wordt de laag ook onder de oppervlakte aangetroffen.

De beworteling houdt gelijke tred met de aëratie. Bij indroging ontstaan grote scheuren. Op de scheurwanden komen wortelgordijnen voor, welke met korte zijwortels eraan vastgehecht zijn. Vermoedelijk ook met wortelharen.

Voortschirijdende indroging heeft de vorming van kleine, harde, scherpe 
aggregaten tot gevolg, die niet doorworteld worden. Zij komen veel onder de bouwvoor voor. De wortels zitten hier los tussen.

$\mathrm{Bij}$ de indroging en verwering van de detritus-gyttja onderscheidt zij zich van de zware zavel door een veel sneller verloop. De zware zavel valt bij dit proces uiteen tot een kruimelige massa. De detritus-gyttja gaat over in een aantal harde brokken. Afwijkingen werden gevonden bij de indroging van een zware laag dicht onder de oppervlakte, rustend op diluviaal zand in sectie M. Deze laag verbrokkelde niet; er ontstonden grote, stevige aggregaten.

In sectie $F$ werd onder de bouwvoor een detritus-gyttjalaag gevonden die bij indroging verweerde tot een kruimelige grond.

Gezien de variërende samenstelling van de detritus-gyttja (WIGGERs), kon er vermoedelijk ook geen sprake zijn van een uniform gedrag. Waar de detritus-gyttja sterk zuur is, werd geen beworteling opgemerkt.

\section{f. De sloef}

Dit is een onder-water-afzetting van zeer fijnzandige en fijngelaagde lichte zavel, met een grote variatie in humusgehalte. De oudste sloef is afgezet in water met een zeer laag zoutgehalte. De jongere afzettingen geschiedden bij een hoger zoutgehalte. Deze afzetting werd benoemd naar de fractie 2-16 mu, de sloeffractie. De sloef onderscheidt zich in de Noordoostpolder van de overeenkomstige lichte zavel met hetzelfde slibgehalte door een lager lutumgehalte. In de sloef is dus het aandeel van de fractie 0-2 mu kleiner dan in de normale zavel.

De sloef is geen homogene afzetting. Van boven naar beneden worden onderscheiden:

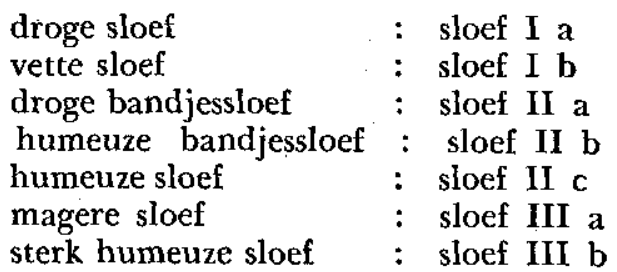

Deze sloeflagen hebben ten aanzien van de beworteling het gemeenschappelijke kenmerk, dat zij weinig of niet toegankelijk zijn.

Aanvankelijk verloopt de aëratie zeer traag, waardoor een grens aan de bewortelingsdiepte wordt gesteld die samenvalt met de bovenkant van de sloef. $\mathrm{Na}$ het voltooien van de rijping blijkt er toch enig verschil op te treden.

De vette sloef (I b) toont enige neiging tot scheuren en daarmee de beste doorworteling.

In de zandige droge sloef $(\mathrm{I}$ a) is de beworteling slechts sporadisch. De al of niet aanwezigheid van droge sloef boven de vette bepaalt daardoor de doorworteling van de vette sloef.

De droge bandjessloef (II a) is ook in geaëreerde toestand niet toegankelijk voor de wortels. Het sterk gelaagde karakter (zand- en humus- 
laagjes) schijnt onoverkomenlijke moeilijkheden voor de beworteling op te leveren. Deze laag voorkomt daarmee de doorworteling van de humeuze sloef (II b en II c) van deze groep, die op zichzelf wel wortels toelaat door het hogere humusgehalte.

De magere sloef (III a) heeft hetzelfde karakter als de droge bandjessloef, komt echter op grotere diepte voor en is daardoor ook van geen betékenis.

De sterk humeuze sloef (III b), meestal op detritus-gyttja voorkomend, is goed doorwortelbaar.

De doorworteling van de sloeflagen wordt dus bepaald door de eigenschappen van de lagen zelf en door de aanwezigheid van wel of niet doorwortelbare bovenliggende lagen.

\section{g. De Zu s}

Dit is een zavellaag afgezet in de tijd waarin het zoutgehalte van het water vrij snel is gestegen. De naam is afgeleid van $\mathrm{Z} u$ (iderzee) en $\mathrm{s}$ (loef) -afzettingen. In het westen van de polder is het een lichte zavel, in het oosten een zware zavel.

Rijping en doorworteling van deze laag gaan uitstekend. De bij de rijping optredende scheuren hebben een grillig verloop, dat past bij het gevlamde karakter dat deze laag in een profielwand te zien geeft.

\section{h. De Zu IV}

Deze en de bovenliggende lagen vormen een zoutwaterafzetting. De $\mathrm{Zu}$ IV bestaat uit zware zavel, die plaatselijk in een vrij dikke laag voorkomt. In deze zavel komen uiterst dunne zandlaagjes voor. Bij de rijping worden platte prisma's gevormd, begrensd door de zandlaagjes.

$\mathrm{De} \mathrm{Zu} \mathrm{IV}$ is goed bewortelbaar; de zandlaagjes vormen geen beletsel.

\section{i. De Zu III}

Dit is een zandlaagje dat zeer rijk kan zijn aan schelpen. De dikte is over het algemeen zo gering, dat het de wortels geen moeilijkheden in de weg legt; het gemiddelde lutumgehalte bedraagt $5 \%$.

De schelpen in dit laagje zijn over het algemeen klein en weinig talrijk. In het westen van de polder is het aantal schelpen echter groot en is de laag $\mathrm{Zu}$ III moeilijk te onderscheiden van de laag $\mathrm{Zu} \mathrm{I}$, daar de zware laag $\mathrm{Zu}$ II ontbreekt en de laag $\mathrm{Zu} \mathrm{I}$ bovendien zandig en zeer schelprijk is. Onder dergelijke omstandigheden vormen de schelpen wel een beletsel.

Indien schelpen in een zavel zijn ingebed, zijn zij minder hinderlijk voor de beworteling dan in zand. Juist in het zand zijn de schelplagen het dichtst, zodat dit een onaangename complicatie is.

De doorwortelbaarheid van het zand wordt bepaald door de dikte van de laag en door de aard van de eronder liggende lagen. Bevindt de zandlaag zich boven $\mathrm{Zu}$ IV of Zus, dan is een dikte van $3 \mathrm{a} .5 \mathrm{~cm}$ nog te overkomen. Ze geeft hoogstens enige tijdelijke remming. Indien de Zu III 
op sloef rust, is een dikte van 2 à $3 \mathrm{~cm}$ reeds bezwaarlijk. Het is niet uitgesloten, dat de variatie in lutumgehalte hierbij van invloed is.

j. De Zu II

Deze laag, bestaande uit zware zavel tot lichte klei, vormt de zwaarste afzetting in de polder. Het gemiddelde lutumgehalte bedraagt $30 . \%$, de grootste dikte ongeveer $15 \mathrm{~cm}$.

Door de hoge ligging in het profiel (vaak direct onder de bouwvoor) en zijn zwaarte rijpt de Zu II snel.

Er ontstaan eerst verticale scheuren, daarna vrij grote prisma's, die zich in steeds kleinere eenheden splijten. Indien de rijping zeer snel verloopt, blijven de eenheden vaak vrij groot, en zijn dan slecht doorwortelbaar.

De beworteling in de Zu II blijft aanvankelijk beperkt tot de scheuren; na de verwering van de grond tot kleine brokjes wordt alles doorworteld.

Op enkele plaatsen komt de $\mathrm{Zu}$ II ook op enigszins grotere diepte voor. De rijping verloopt daar langzamer en blijft beperkt tot de scheurvorming. De doorworteling is evenwel goed.

\section{k. De Zu I}

De $\mathrm{Zu} \mathrm{I}$ bestond bij het droogvallen uit zavel van zeer uiteenlopende zwaarte, waarin zandlaagjes voorkwamen. Daar deze laag bijna geheel tot de bouwvoor behoort, is de doorworteling geen probleem. De mate van beworteling wordt geheel bepaald door de structuur ervan, die uiteraard sterk beïnvloed wordt door alle behandelingen die zij ondergaat. In sectie E, waar de $\mathrm{Zu}$ I zeer dik is (tot $50 \mathrm{~cm}$ ), wordt het gedeelte onder de bouwvoor gevormd door lichte afzettingen. Op de plaatsen waar deze lagen uit zand bestaan, worden zij niet doorworteld.

1. De $\mathrm{Zu} 0$

Deze laag is plaatselijk in het westen en zuidwesten van de polder afgezet tijdens en na de dijkbouw; zij is geheel met de bouwvoor vermengd en levert dientengevolge geen moeilijkheden voor de beworteling op.

m. Het Urkzand

In de omgeving van Urk, Tollebeek en De Voorst komen vrij grote complexen van dit zand voor, afkomstig van in de nabijheid liggende keileem-gebieden.

Het bestaat uit kleiarm, matig fijn zand. Dit betekent een lutumgehalte van enkele procenten en een U-cijfer van $50-80$.

Het schelphoudend zand wordt slecht doorworteld. Waar in de ondergrond het Urkzand zuur is, dringen de wortels er hoogstens $10 \mathrm{~cm}$ in. De wortels zijn dan kronkelig, verdikt en vaak trosvormig vertakt.

Het Nagelezand in sectie J, dat onder de bouwvoor en dieper voorkomt, gelijkt in gedrag ten aanzien van de beworteling geheel op Urkzand. De wortels gaan er niet in. 


\section{n. Het Kuinrezand}

In de omgeving van Kuinre komt dit zand voor, in afwisseling met Blokzijlzand. Het Kuinre- en Nagelezand is afkomstig van verplaatst diluviaal zand. Dit kleiarme middelfijne zand (U cijfer 80-120) wordt niet of slecht doorworteld. Waar het aan de oppervlakte komt, gaan de wortels er nog wel in. Dieper gelegen lagen zijn niet toegankelijk.

\section{o. Het Ramspolzand}

Het Ramspolzandgebied ligt in de secties $P$ en $Q$ en behoort tot de IJsseldelta. Het bestaat uit kleihoudend, matig fijn zand (3-8\% lutum, U-cijfer 50-80). Het lutumpercentage is in de kern van het gebied lager dan aan de randen.

Waar het lutumgehalte het laagst is, vertoont de beworteling dezelfde afwijkingen als in Urkzand: kronkelige en verdikte wortels, die moeilijk in het zand dringen. $\mathrm{Bij}$ hogere lutumgehaltes ontmoet de beworteling geen tegenstand. De hoofdwortels kunnen in dit gebied een diepte van 80 à $100 \mathrm{~cm}$ bereiken. Zijwortelvorming vindt voornamelijk plaats in de kIeilenzen die zich in het zand bevinden.

\section{p. Het Espelzand}

In het westen van de Noordoostpolder komt in en onder de oppervlakte een laag voor van zeer fijn zand (U-cijfer 120-180) met een lutumgehalte van 3-5\%. Het behoort tot de Zu III-afzetting (zie i), die in deze gebieden samenvalt en overgaat in de Zu I. Dit zand wordt in de wandeling Espelzand genoemd. WIGGERs gebruikt deze naam echter niet.

Het Espelzand aëreert langzaam en is ook na aëratie moeilijk voor de wortels toegankelijk. Waar het Espelzand tot in de bouwvoor komt, wordt het in de bouwvoor goed doorworteld; eronder echter veel geringer. In de loop der jaren is de doorworteling van het Espelzand iets beter geworden.

\section{q. Het Blokzijlzand}

Het Blokzijlzandgebied strekt zich in het oosten van de polder uit tussen Blankenham en Vollenhove. Het zand bevat 3-5\% lutum en is uiterst fijn (U-cijfer 270-400). Indien dit zand geaëreerd is, kunnen de wortels goed in de diepte groeien. De zijwortelvorming is matig. De zijwortels blijven kort en zijn betrekkelijk dik. Ook de hoofdwortels zijn dikker dan in zavel.

\section{De beworteling in storende lagen}

In het algemeen ontmoeten de wortels in zavellagen geen moeilijkheden. De enige beperking wordt veroorzaakt door de aëratie. In niet geaëreerde grond groeien de wortels slechts over een beperkte afstand en vermoedelijk alleen, indien de aëratie de wortels. snel volgt, al is het slechts in de vorm van een dun aëratiewandje om de wortels heen. De 
voorkeur van de wortels wijst wel in de richting van zuurstofbehoefte. Het is opvallend, dat de kiemwortels van de granen en de hoofdwortels van de tweezaadlobbigen minder gevoelig voor ongunstige omstandigheden zijn dan de kroonwortels en de zijwortels. Dit is reeds in de bouwvoor waarneembaar. De hoofdwortels wijken hier slechts zelden van hun verticale groeirichting af, terwijl de zijwortels een sterke neiging hebben om langs de buitenkant van verdichte aggregaten te groeien. Het is mogelijk, dat de minder uitgesproken verticale groeirichting hierbij van invloed is.

De in ongeaëreerde lagen groeiende wortels vertonen geen afwijkingen in hun uiterlijk en groeisnelheid ten opzichte van wel geaëreerde lagen. Wel is de zwaarte der lagen van betekenis. De ongeaëreerde zware zavel wordt wel doorworteld, de ongeaëreerde lichte zavel niet.

Het gedrag der wortels in min of meer dikke zandlagen is zeer afhankelijk van de aard en de wijze van voorkomen van deze zandlagen in het profiel.

Het Urk-, Kuinre-, Nagele- en dekzand laat in het algemeen geen doorworteling toe. Ongeacht de vochtigheid van deze zandsoorten, wordt de groei van de wortels geremd. Nadat de wortels enkele centimeters in het zand zijn doorgedrongen, houdt de groei op, waarbij knotsvormige verdikkingen van de worteltop optreden. De wortels hebben daarbij een zeer kronkelig verloop gekregen. Achter de top komen daarna zijwortels te voorschijn die, na in het zand gedrongen te zijn, hetzelfde beeld tonen als de hoofdwortel. Op deze manier eindigen de wortels in een trosje in het zand (fig. 34, 35 en 36).

In het Ramspol-, Espel- en Blokzijlzand worden de wortels niet tegengehouden. De groei geschiedt echter langzamer dan in zavelprofielen, terwijl de wortels in het algemeen iets dikker zijn. Bij het vrijspoelen van naaldenplanken vallen de wortels uit de zandlagen steeds op door hun wittere kleur en iets grotere dikte. De verdikte worteltoppen komen in deze zandsoorten eveneens voor, maar niet zo sterk als in de vorige groep. De groei van de zijwortels is wel geremd. Vooral in Blokzijlzand zijn die vaak kort.

De doorworteling in lutumhoudend Ramspol- en Blokzijlzand is beter. Sterk gelaagde afzettingen zijn vrijwel ontoegankelijk voor de wortels. Hierbij is het tegenhoudende karakter sterker naarmate de laagjes dunner zijn en de tegenstelling in samenstelling tussen de laagjes groter is.

In de droge bandjessloef (II a), bestaande uit dunne laagjes uiterst fijn zand afgewisseld met humeuze laagjes, lopen de wortels na enkele centimeters dood in een zandlaagje. De wortel groeit horizontaal, wordt knotsvormig en heeft enige neiging tot trosvorming.

In fijn gelaagde $\mathrm{Zu}$ I-afzettingen in sectie $\mathrm{C}$ is iets dergelijks waargenomen.

De sloef $1 \mathrm{~b}$, die in het westen van de polder licht is, heeft ook een fijn gelaagd karakter, doch de tegenstelling tussen de laagjes is geringer. De beworteling is hier normaler.

In grof gelaagde zavel met Espelzand werd het bewortelingsbeeld van 
de sloef IIa evenmin aangetroffen.

Schelpen, al of niet in lagen, kunnen door de wortels gepasseerd worden, indien zij er omheen kunnen groeien. Verschillende malen werd in de naar boven gekeerde holte van een halve schelp een spiraalvormige wortel aangetroffen, welke blijkbaar de uitweg niet spoedig had gevonden.

Zeer dichte en dikke schelplagen (banken) kunnen een ernstige tegenstand bieden. Indien deze schelpen in een zavellaag voorkomen, worden zij wel gepasseerd. Ingebed in zand, worden zij onoverkomelijk. Daar dit de meest voorkomende toestand bij de schelpenbanken is, vormen deze dus steeds een belemmering. De wortelgroei onder remmende lagen wordt normaal, indien de onderliggende lagen goed doorwortelbaar zijn. Dit blijkt uit de beworteling in de $\mathrm{Zu}$ IV en Zus onder het $\mathrm{Zu}$ IIIzandlaagje en uit de doorworteling van de Zus en de Espelzandlaag in het westen.

Overzicht van het gedrag der wortels van verschillende gewassen in storende lagen

Het hierboven besproken gedrag der wortels gaat in het algemeen op voor al de. onderzochte gewassen. De gewassen reageren echter niet volkomen gelijk. Winter- en zomertarwe en zomergerst komen in het doordringingsvermogen van de kiemwortels overeen. Haver is gevoeliger voor ongunstige omstandigheden en lijkt dan minder diep te wortelen dan de reeds genoemde granen. Winterrogge heeft vermoedelijk een iets groter doordringingsvermogen. Geheel te beoordelen is dit echter niet, omdat winterrogge slechts enkele keren werd onderzocht.

Deze globale indruk komt overeen met het overzicht dat GoEDEWAAGEN (1942) geeft van de bereikte diepte van verschillende gewassen (overgenomen van WEAVER). Uit deze overeenkomst behoeft niet te volgen, dat het gedrag dezer gewassen hiermede inderdaad is bepaald. De omstandigheden van de verschillende waarnemingen wijken te zeer af (afgezien nog van de rasverschillen), dan dat aan het al of niet overeenkomen grote waarde moet worden gehecht. Hiermede wordt de uitspraak van VAN LIESHOUT (1956), dat ,de resultaten van dit onderzoek alleen geldig zijn voor ter plaatse heersende omstandigheden", geheel onderschreven.

De hoofdwortel van de erwt heeft een doordringingsvermogen dat overeenkomt met dat van de granen. De zijwortelvorming wordt echter zeer sterk beïnvloed door de aard van de grond. Trosvorming in een zandlaag door de hoofdwortel werd niet waargenomen.

De penwortel van vlas wijkt daarentegen zeer gemakkelijk van de verticale richting af en vertoont in zandlagen sterke vertakking en verdikking.

Verdikking van de wortels van suikerbieten in zandlagen werd niet waargenomen. De wortels vertonen echter wel spoedig krommingen en vertakkingen. 
Bij winterkoolzaad werden nooit verdikte en sterk kronkelige wortels aangetroffen. Dit gewas reageert op zandige lagen met een vrij normale maar intensieve zijwortelvorming boven de remmende laag. De zijwortels hebben een sterke neiging om naar beneden te groeien. Indien het aantal groot is, kan naar verhouding de zandige laag nog vrij goed doorworteld zijn.

Bij luzerne komen verdikking en trosvorming wel voor. Door de langere groeiperiode is het gewas wel in staat enigszins remmende lagen binnen te dringen, doch het vermogen hiertoe is geringer dan dat van bieten. Luzerne heeft ten aanzien van het indringen in ongunstige lagen geen bijzondere eigenschappen.

Een beschouwing over de mogelijke oorzaken van beperkte of ontbrekende wortelgroei

De volgende verschijnselen zijn geconstateerd bij het bewortelingsonderzoek:

1. In ongeaëreerde zavel met meer dan 10 à $12 \%$ lutum kunnen de wortels van de landbouwgewassen over een bepaalde afstand groeien.

2. In een geaëreerde grond met minder dan $5 \%$ lutum wordt de wortelgroei meer of minder belemmerd, afhankelijk van de opbouw van het profiel.

3. Dunne zandlagen ( 1 à $3 \mathrm{~cm}$ ), liggende tussen goed doorwortelbare lagen, vormen geen belemmering.

4. Zandlagen van 1 à $3 \mathrm{~cm}$, liggende op een moeilijk of niet doorwortelbare laag, zijn slecht toegankelijk.

5. Een laagsgewijze opbouw (afwisselend zand en min of meer humeuze zavel) is bezwaarlijker voor de beworteling naarmate de dikte van de laagjes geringer is.

6. In rijpende en pas gerijpte grond is de wortelontwikkeling het sterkst in de scheuren.

7. In zandprofielen ontmoeten de hoofdwortels minder moeilijkheden dan de zijwortels. De wortels in het zand zijn gewoonlijk dikker dan die in de zavel.

8. Rietwortels worden aangetroffen in voor de wortels der landbouwgewassen wel en niet toegankelijke lagen.

9. De lagen die langzaam aëreren (te oordelen naar de kleur), worden slecht doorworteld.

10. Door een ondergrondbewerking worden echter deze voor de wortels ontoegankelijke lagen zeer goed doorwortelbaar.

11. Worteltopverdikkingen worden wel aangetroffen in ontoegankelijke zandlagen, maar niet in ongeaëreerde zavel waarin de wortels wel over korte afstand groeien. Woteltopverdikkingen komen ook voor, indien de wortels eindigen in fijn gelaagde sloef.

Een verklaring voor afwezige of beperkte wortelgroei in bepaalde lagen zou op grond van de opgesomde verschijnselen kunnen worden gezocht in: 
a. de vochtvoorziening;

b. de voedselvoorziening;

c. de dichtheid (pakking) van de grond;

d. de zuurstofvoorziening;

e. andere factoren.

\section{a. De vochtvoorziening}

Een onvoldoende vochtvoorziening van de plantewortel in het zand moet, hoewel mogelijk, als primaire oorzaak worden uitgesloten. In losgemaakte zandlagen, waarin het vochtgehalte echter niet hoger zal zijn dan in vaste Iagen, kunnen de wortels ongestoord groeien. Zij zijn zelfs in staat aan het losgemaakte zand zoveel vocht' te onttrekken, dat voor een zekere (zij het beperkte) tijd de vochtvoorziening van een gewas hierop uitsluitend kan berusten.

Verschillende malen werd ook opgemerkt, dat het zand onder een zavellaag vochtig was op het ogenblik dat de eerste wortels de grens zavel-zand bereikten. Er blijft nog de mogelijkheid dat aanvankelijk het vochtgehalte van het zand te hoog zou zijn, waardoor, bij gebrek aan zuurstof, wortelgroei onmogelijk zou zijn. Vanaf deze toestand (te nat) tot het moment dat het zand bij de grenslaag uitgedroogd is (te droog), moet een traject voorkomen dat althans ten aanzien van het vochtgehalte gunstig voor de plantewortel moet zijn.

Het geval dat deze verandering zo snel zou plaatsvinden dat de wortel geen gelegenheid heeft om van een gunstige toestand te profiteren, is denkbaar indien de poriënwijdte in het zand zeer weinig variatie vertoont. Het voorkomen van niet meer groeiende worteltoppen in vochtig zand sluit echter de vochtvoorziening als oorzaak uit.

HuNTER en KELLEY toonden aan, dat maïswortels, komende uit een vochtige grond, in een droge grond kunnen groeien. Bij hun proeven was het beschikbare vochtige grondvolume (potproeven) echter zeer beperkt, zodat het nog de vraag is, of de wortels dit ook zullen doen, indien zij over een groot vochtig grondvolume beschikken.

\section{b. De voedselvoorziening}

Met betrekking tot de voedselvoorziening kan een zelfde redenering worden toegepast. In losgemaakt zand groeien de wortels wel, in niet losgemaakt zand niet. Ofschoon de waterbeweging sneller gaat in een losgemaakte zandlaag en dus een betere doorspoeling met uit de bovenliggende zavellaag afkomstig water kan plaatsvinden, is niet te verwachten dat de voedselvoorziening daardoor beter zal worden, omdat de absorbtiecapaciteit van het zand door het losmaken niet verandert. Overigens is voedselarmoede van een grond geen bezwaar voor de wortelontwikkeling, zoals GoEdEWAaGen (1942), GLIEMERoth (1953) en anderen meermalen hebben aangetoond. 
c. De dichtheid van de grond

Het is mogelijk de betekenis van de vocht- en voedselvoorziening apart te behandelen; voor de invloed van de dichtheid (pakking, volumengewicht) en de zuurstofvoorziening is dat niet wel mogelijk, ofschoon elk van beide factoren eigen aspecten biedt die onafhankelijk van de andere kunnen worden beschouwd.

De aard van de bodemlagen wordt bepaald door de granulaire samenstelling en de ligging van de korrels ten opzichte van elkaar. Indien de ligging van de korrels ten opzichte van elkander onveranderbaar is (dus star), wordt de doorwortelbaarheid volgens WIERSUm (1957ab) bepaald door de afmetingen van de poriën. Volgens metingen van deze auteur is de kleinste worteldikte van landbouwgewassen $100 \mathrm{mu}$, het merendeel ligt echter boven $200 \mathrm{mu}$.

Indien nu de zandkorrels als bollen van uniforme grootte in hun dichtste pakking worden gedacht, wordt de dikte van de wortels begrensd door de holte tussen de zandkorrels. De diameter (d) van de cilinder die tussen drie korrels kan worden geplaatst, is afhankelijk van de diameter (D) van de zandkorrels. Dit verband wordt bepaald door: $\mathrm{d}=\mathrm{D}(2 / 3 \sqrt{ } \mathrm{3}-\mathrm{I})$.

Voor worteldikten van 100 en $200 \mathrm{mu}$ zijn nodig korreldiameters van respectievelijk 645 en $1290 \mathrm{mu}$.

WIERSUM (1957b) vermeldt bij een worteldikte van $200 \mathrm{mu}$ een korreldiameter van $800 \mathrm{mu}$. Dit verschil in uitkomst is niet belangrijk, want de korrels zijn geen zuivere bollen.

De grofste fractie van Urkzand (zie tabel 6) heeft een diameter van meer dan $420 \mathrm{mu}$. Deze fractie omvat $10 \%$ van het totaal. Dit betekent, dat de verschillende zandsoorten geen van alle doorwortelbaar zouden zijn, indien zij in hun dichtste pakking zouden liggen. Uiteraard is dit niet juist, omdat de zandkorrels niet bolvormig zijn (het tegendeel is het geval).

Een starre structuur is evenmin waarschijnlijk. Deze wordt alleen aangetroffen in de B-laag van het pleistocene zand, waarin de zandkorrels aan elkaar zijn gekit.

In verschillende zandsoorten werd opgemerkt, dat de zijwortelontwikkeling zeer gering is, in tegenstelling tot de zijwortelontwikkeling in zavel. De oorzaak hiervan kan als volgt worden gedacht.

$\mathrm{Bij}$ het groeien van de hoofdwortel vindt in de onmiddellijke omgeving van deze wortel een kleine onderlinge verschuiving van de zandkorrels plaats, om ruimte te maken voor de wortel, dat wil zeggen: de hoofdwortel dringt de zandkorrels opzij. Indien door deze kleine verplaatsing de onmiddellijke omgeving bijna of geheel star wordt, is het voor de zijwortels niet mogelijk zijwaarts te groeien. Vervormingen in de structuur, veroorzaakt door de wortelgroei, worden door JonGERIUs beschreven.

De vervormbaarheid van de structuur (de plasticiteit) wordt o.a. bepaald door de samendrukbaarheid, de vorm van de korrels en de vulstof. 
De vervormingsmogelijkheid kan worden uitgedrukt in het volumegewicht. VeIHMEYer en Hendrickson (1948) vonden de grens van de doorwortelbaarheid bij een volumegewicht van 1,8. BERTRAND en KOHNKE bij 1,5 . De eersten wijten dit aan te kleine poriën, de tweeden aan onvoldoende zuurstofvoorziening.

Of de zandkorrels ten opzichte van elkaar kunnen worden verschoven, hangt echter ook af van de wrijving tussen de korrels. De oppervlakte van de korrels kan glad of ruw zijn, afhankelijk o.a. van de herkomst. Deze wrijving kan worden verkleind door het zich in het zand bevindende water en eventueel het aanwezige lutum. Ten aanzien van de invloed van het lutumgehalte kan de granulaire samenstelling uitsluitsel geven. In tabel 6 is deze samenstelling van de verschillende zanden vermeld, waaruit dus tevens een mogelijke invloed van de fijnheid van het zand kan blijken.

TABEL 6. Samenstelling van het zand in \% van de droge stof.

\begin{tabular}{|c|c|c|c|c|c|c|c|c|c|c|c|}
\hline & $\begin{array}{l}\mathrm{Hu}- \\
\text { mus }\end{array}$ & $\left|\begin{array}{c}0 \\
2 \mathrm{mu}\end{array}\right|$ & $\begin{array}{c}16- \\
50 \mathrm{mu}\end{array} \mid$ & $\begin{array}{c}50- \\
75 \mathrm{mu}\end{array}$ & $\begin{array}{c}75- \\
105- \\
\mathrm{mu}\end{array}$ & $\begin{array}{c}105- \\
150- \\
\mathrm{mu}\end{array}$ & $\begin{array}{c}150- \\
210- \\
\mathrm{mu}\end{array}$ & $\begin{array}{c}210- \\
300- \\
\mathrm{mu}\end{array}$ & $\begin{array}{c}300- \\
420- \\
\mathrm{mu}\end{array}$ & $\begin{array}{c}420- \\
\mathrm{mu}\end{array}$ & $\begin{array}{c}\text { U- } \\
\text { cijfer }\end{array}$ \\
\hline $\begin{array}{l}\text { Urkzand }^{1} \text { ) } \\
\text { Pleistoceen } \\
\text { zand }^{1} \text { ) } \\
\text { Nagelezand }^{1} \text { ) } \\
\text { Kuinrezand }^{\mathbf{1}} \text { ) } \\
\text { Ramspolzand }^{\mathbf{2}} \text { ) } \\
\text { Espelzand }^{2} \text { ) } \\
\text { Blokzijlzand }^{2} \text { ) }\end{array}$ & $\begin{array}{l}0.6 \\
0.6\end{array}$ & $\begin{array}{l}1.0 \\
1.5 \\
1.2 \\
5.9 \\
3.7 \\
3.5\end{array}$ & $\begin{array}{r}2.8 \\
2.6 \\
2.2 \\
3.7 \\
10.4 \\
49.5\end{array}$ & \begin{tabular}{|r|}
6.3 \\
2.3 \\
2.8 \\
1.1 \\
31.1 \\
23.2
\end{tabular} & $\begin{array}{r}11.2 \\
3.3 \\
3.1 \\
2.9 \\
37.9 \\
6.5\end{array}$ & $\begin{array}{r}22.5 \\
16.1 \\
18.9 \\
21.1 \\
6.9 \\
1.8\end{array}$ & \begin{tabular}{|r|}
29.5 \\
32.1 \\
38.0 \\
39.1 \\
0.6 \\
2.8
\end{tabular} & \begin{tabular}{r|}
38.0 \\
\multicolumn{1}{c}{} \\
17.9 \\
27.9 \\
25.7 \\
13.8 \\
0.3 \\
1.9
\end{tabular} & \begin{tabular}{|r|}
22.6 \\
5.6 \\
10.2 \\
6.6 \\
2.4 \\
0.1 \\
0.5
\end{tabular} & $\begin{array}{l}1.2 \\
2.8 \\
1.0 \\
0.4 \\
0.2 \\
0.1\end{array}$ & $\begin{array}{r}80 \\
64 \\
66 \\
76 \\
157 \\
274\end{array}$ \\
\hline
\end{tabular}

TABLE 6. The composition of the sand in $\%$ of the dry matter.

1) Niet of moeilijk doorwortelbaar - Not or poor accessible to roots.

2) Matig tot vrij goed doorwortelbaar - Moderate accessible to roots.

Twee criteria kunnen hier worden aangelegd, het $\mathbf{U}$-cijfer en het lutumgehalte. Het U-cijfer heeft geen invloed op de doorwortelbaarheid, vgl. Pleistoceen- en Ramspolzand, met een ongeveer gelijk U-cijfer.

De niet- en wel-doorwortelbare zanden verschillen wel in lutumgehalte. Het hogere lutumgehalte kan dus wel als een factor worden be schouwd. Blijkbaar is dan voldoende lutum aanwezig om door middel van brugvorming het zand in een lossere pakking te houden. Daarnaast dient aandacht te worden geschonken aan de zijwortelontwikkeling bevorderende invloed die van de lutum uitgaat (WIERSUM, 1957 a).

De verlaging van de inwendige wrijving door water zou inhouden, 
dat de doorwortelbaarheid toeneemt met een toenemend vochtgehalte tot de verzadingsgrens. De aanwezigheid van rietwortels in grote hoeveelheden in lagen waarin (ook bij volledige aëratie) geen wortels van landbouwgewassen groeien, kan op deze verzadiging met water berusten. De rietgroei vond voornamelijk plaats, voordat nog van enige oppervlakkige ontwatering sprake was. Het is bekend, dat rietwortels in ongeaëreerde grond kunnen groeien. De verklaring is, dat de zuurstofvoorziening geschiedt door luchtkanalen in de wortels. Het is hierbij wel merkwaardig, dat de doorsnede van de rietwortels in de zandlagen groter is dan in de zavel. Waar zand- en veenlagen elkaar afwisselden, werd zelfs gevonden dat dezelfde wortel in het zand een grotere doorsnede had dan in het veen. Op het oog werd het verschil veroorzaakt door een grotere dikte van de cortex, waarin het parenchym stervormig om de centrale cilinder was samengetrokken. De luchtholten waren daardoor zeer ruim.

- Ofschoon de rietwortels, gezien hun grote hoeveelheid, weinig moeite hadden om het natte zand te doorwortelen, ging van het zand toch blijkbaar een invloed uit die de versterkte diktegroei veroorzaakte.

De dikkere wortels, die in de regel ook lichter van kleur zijn, werden o.a. opgemerkt door Kraus, KöhnLEIn en VeTtER en BerkManN.

BERKMANN schrijft, dat de mechanische remming van de lengtegroei de diktegroei van de wortels bevordert, en haalt overeenkomstige waarnemingen van Pfeffer en Polle aan.

KöHNLEIN en VeTTER constateerden, dat de remming van de lengtegroei vooral voorkwam, indien een zandige leemhoudende grond erg nat was.

Fox en Lipps (1955,a.b) merkten, dat luzernewortels niet in vochtig grof zand gingen, maar wel in fijn slibhoudend zand.

GOEDEWAAGEN $\left(1955,{ }^{a}\right)$ concludeert uit de verschillende waarnemingen in Nederland, dat de mechanische weerstand als hoofdoorzaak van de belemmerde wortelgroei in zand moet worden beschouwd, juist omdat na het losmaken de wortelgroei niet meer gehinderd is.

Deze waarnemingen wijzen erop, dat aan de mechanische weerstand van de grond (dus de starheid van de structuur), hetzij door de gesloten ligging, hetzij door de te grote inwendige wrijving, bij de belemmering van de wortelgroei een zekere rol moet worden toegekend.

\section{d. De zuurstofvoorziening}

Er bestaan echter aanwijzingen, dat de zuurstofvoorziening ook een rol speelt.

De zuurstofvoorziening is een primaire eis voor de wortelgroei van de landbouwgewassen (Lokhwing, Peterson). Wortels worden alleen aangetroffen in geaëreerde grond, waarbij enige voorkeur voor holten in de ondergrond wordt getoond, indien de aëratie nog niet volledig tot stand is gekomen. Het enkele malen voorkomen van wortels in ongeaëreerde grond is hiermede niet in strijd; omdat de aëratie zeer 
spoedig op de wortelgroei volgt. Een zuurstofvoorziening door de wortel heen is hierbij niet uitgesloten.

BRYANT vond in de wortels van zomergerst, gegroeid in een niet geaëreerde voedingsoplossing, luchtkanalen.

Het voorkomen van de wortels in de nog blauwe grond wijst erop, dat het ijzersulfide niet schadelijk is.

Het verschil in gedrag ten aanzien van ongeaëreerde grond met meer of minder dan 10 à $12 \%$ lutum kan veroorzaakt zijn door een verschil in aëratiesnelheid. De zwaardere zavel vertoont bij waterontwikkeling een sterkere scheurvorming dan de lichtere zavel, zodat de toetreding van lucht in de zwaardere zavel door de scheuren beter kan zijn. Bij een geaëreerde toestand van de grond ligt de grens bij ongeveer $5 \%$ lutum; bij ongeveer $3 \%$ lutum ligt de grens voor de doorwortelbaarheid van de zandsoorten. Bij afnemend lutumgehalte wordt de scheurvorming en de vervormbaarheid geringer.

Een zekere samenhang tussen zuurstofvoorziening, mechanische weerstand en doorwortelbaarheid is dientengevolge goed denkbaar.

De grotere mechanische weerstand van grond met een laag lutumgehalte kan worden overwonnen, indien de zuurstofvoorziening goed is, dat wil zeggen: wanneer de grond in geaëreerde toestand verkeert.

Dit is geheel in overeenstemming met de resultaten van het onderzoek van GiLl en Miller. Zij vonden, dat voor de wortelgroei het minimum zuurstofgehalte in de omgeving van de wortels hoger moet zijn naarmate een grotere druk door het wortelmilieu (in dit geval glasparels) op de wortels wordt uitgeoefend. In hun proefopzet werd de druk van een luchtkamer via een rubber membraan op het wortelmilieu overgebracht. Deze opstelling waarborgde een zekere mate van plasticiteit in het wortelmilieu.

Het wel voorkomen van rietwortels wordt verklaard door de aanwezigheid van luchtkanalen in de wortels, welke de zuurstofvoorziening waarborgen. Ook bij andere gewassen, zoals rijst, werd dit geconstateerd (Alberda, Roodenburg). De aëratiekokertjes, welke steeds om de in de blauwe grond groeiende wortels van landbouwgewassen worden aangetroffen, komen bij de rietwortels niet voor.

Er is een parallellie tussen de snelheid van de rijping van de grond en zijn doorwortelbaarheid. Deze laat zich niet alleen vaststellen bij het verschil tussen zwaardere en lichtere zavel, maar ook bij de sloef. De laagsgewijze opbouw van deze lichte zavel, welke naar verhouding een te laag lutumgehalte bezit, is blijkbaar bezwaarlijk voor een goede luchttoetreding. Het is bovendien aannemelijk, dat in deze grond tengevolge van het lage lutumgehalte (en de daaruit volgende lage hoeveelheid aanwezig extra water bij het droogvallen van de polder) na wateronttrekking veel scheurvorming achterwege blijft en de luchttoetreding daardoor ook slechter is.

De aëratie van de sloeflagen verloopt langzamer dan van de zavel. De vette sloef aëreert echter vlugger dan de droge. De doorworteling van de sloef vertoont overeenkomstige tendensen. 
De snelle aëratie van zand, geconcludeerd uit het verdwijnen van de blauwe kleur, garandeert nog niet dat de luchtvoorziening erin goed is. QuisPEL wees er reeds op, dat de verandering van de intensiteit van de blauwe kleur geen juiste maatstaf is voor het beoordelen van de zuurstofvoorziening van de grond. De loutere aanwezigheid van een bepaalde hoeveelheid zuurstof in de grond is niet van belang. De snelheid van de aanvulling van verbruikte zuurstof is bepalend voor de mogelijkheid van groei van zuurstofbehoevende organismen. Indien in een zandlaag een geringe hoeveelheid oxydeerbaar materiaal aanwezig is, kan deze hoeveelheid met minder zuurstof worden omgezet dan wanneer een grote hoeveelheid gereduceerd materiaal aanwezig is. Het verdwijnen van de blauwe kleur geeft daarom geen inlichtingen omtrent de diffusiesnelheid van de zuurstof in de grond. Uit de afwezigheid van een blauwe kleur in zandlagen mag daarom niet worden besloten, dat de zuurstofvoorziening goed is.

Het is daarom ook niet juist om uit het parallel lopen van aëratiesnelheid en doorwortelbaarheid te concluderen, dat beide bepaald worden door de zuurstofvoorziening. Het bestaan van een factor die beide beïnvloedt, is zeer goed denkbaar.

Behalve de zuurstofvoorziening is de afvoer van koolzuur zeer belangrijk. Beide worden echter bepaald door de diffusie in de grond. Uit onderzoekingen en literatuuroverzichten (AlbERDA, 1955, BERTRAND en Kohnke, Loenwing, Peterson, Wesseling) volgt, dat zuurstofvoorziening en koolzuurafvoer niet van elkaar zijn te scheiden, daar hun diffusiesnelheid in de grond wordt bepaald door de grond zelf. Wel is het mogelijk de invloed van verschillende concentraties zuurstof en/of koolzuur op de wortelgroei te onderzoeken en aan te geven tussen welke grenzen deze mogen variëren.

WESSELING en BERTRAND en KoHNKe geven aan, op welke wijze er een verband bestaat tussen het luchtgehalte (volumegewicht van de grond) en de zuurstofvoorziening (koolzuurafvoer).

Bij een luchtgehalte kleiner dan $13 \%$ van het bodemvolume is diffusie van de lucht niet mogelijk, volgens WEsSELING.

Volgens BERTRAND en KoHNKE wordt de wortelgroei van maïs in toenemende mate minder naarmate de diffusiesnelheid in de grond lager komt dan $16 \%$ van die in de vrije lucht. Boven deze diffusiesnelheid van $16 \%$ vinden deze auteurs geen verbetering van de opbrengst. Deze diffusiesnelheid komt volgens gegevens van WESSELING overeen met een met lucht gevuld poriënvolume van $29 \%$.

Gezien de sterk uiteenlopende behoeften van verschillende gewassen, zal de genoemde grens lang niet altijd gelijk zijn. BERTRAND en KoHNKE achten een onvoldoende zuurstofvoorziening eerder aansprakelijk voor de belemmering van de wortelgroei dan de mechanische weerstand van de grond. $\mathrm{Zij}$ constateren, dat natte grond, ondanks de grotere plasticiteit, niet werd doorworteld.

De eerder genoemde gemeenschappelijke factor die de rijpingssnelheid en de wortelgroei beïnvloedt, kan gezocht worden in het poriëngehalte, 
beter in het watervrije poriëngehalte, van de grond, waardoor de diffusiesnelheid van de lucht wordt bepaald.

Zowel Wesseling als Bertrand en Kohnke komen tot de conclusie (overigens op grond van dezelfde gegevens), dat er een rechtlijnig verband bestaat tussen het luchtgehalte en de diffusiesnelheid.

e. Andere factoren.

Behalve de tot dusverre besproken factoren kunnen er nog andere eigenschappen van het zand zijn die de wortelgroei beïnvloeden.

Naar aanleiding van het gedrag der wortels in de verschillende zandsoorten werd het niet uitgesloten geacht, dat de vorm van de zandkorrels invloed kan hebben, o.a. in verband met de plasticiteit van het zand. De vorm van de zandkorrels is van tweeërlei aard: ten eerste de bolvormigheid (sphericity), welke aangeeft in hoeverre de algemene ruimtelijke gedaante overeenkomt of afwijkt van de bolvorm; ten tweede de afronding (roundmess), welke aangeeft of de hoeken en randen van de korrels afgerond of scherp zijn. De vergelijking tussen een rolsteen, een windkei en een afgeslagen stuk graniet makt het verschil duidelijk. Een rolsteen kan zowel de bolvorm benaderen als tevens geheel afgerond zijn. Een windkei heeft wel afgeronde hoeken en ribben, maar behoeft zeker niet de bolvorm te benaderen. Een willekeurig afgeslagen stuk graniet zal zomin bolvormig zijn als afgeronde hoeken en ribben hebben.

Bij de bespreking van de pakking en plasticiteit van zand werd op deze vormen gedoeld.

De bolvormigheid van de zandsoorten werd geschat bij waarnemnig door een binoculaire loupe volgens een door RITTENHOUSE opgestelde schaal. De schaal berust op de vergelijking van de langste en de kortste afmetingen van de zandkorrels bij projectie op een vlak. Zijn deze gelijk, ook in verschillende richtingen, dan ligt de waardering tussen 90 en 100. Indien deze sterk uiteenlopen (bijna meer dan viermaal zo lang als breed), dan wordt de bolvormigheid gewaardeerd met een laag getal, b.v. 40 a 50 . Door de verkregen schattingscijfers van een aantal korrels te middelen wordt een indruk van de bolrondheid verkregen.

Tevens werd gelet op de afronding van de korrels.

Tabel 7 geeft een overzicht van deze waarnemingen.

Uit deze gegevens volgt dat er weinig verschil in bolvormigheid van de zandsoorten is. De fractie 0-50 mu en in mindere mate ook de fractie 50-105 mu zijn bij alle zandsoorten scherp, hoekig, zodat de granulaire samenstelling de afronding in zekere mate beïnvloedt. Wanneer, zoals bij Kuinre- en Ramspolzand, de granulaire samenstelling overeenkomst vertoont, is het onderscheid in afronding toch wel duidelijk.

De door de IJssel of de zee aangevoerde zandsoorten zijn sterk hoekig, waarbij het Ramspolzand opvalt door de scherpe breukranden. Welke invloed deze eigenschappen hebben op de plasticiteit en de pakking, is niet aan te geven. 
TABer 7. De bolvormigheid van de korrels der zandsoorten in de Noordoostpolder, geschat volgens RITTENHOUSE.

\begin{tabular}{|c|c|c|c|c|c|c|}
\hline & $0-50 \mathrm{mu}$ & $\frac{50-}{105 \mathrm{mu}}$ & $\frac{105-}{210 \mathrm{mu}}$ & $\begin{array}{l}210- \\
420 \mathrm{mu}\end{array}$ & $>420 \mathrm{mu}$ & $\begin{array}{l}\text { Gemiddelde } \\
\text { afronding }\end{array}$ \\
\hline $\begin{array}{l}\text { Urkzand . . } \\
\text { Pleistoceen } \\
\text { zand . . } \\
\text { Nagelezand . } \\
\text { Kuinrezand } \\
\text { Ramspolzand. } \\
\text { Espelzand . } \\
\text { Blokzijlzand . }\end{array}$ & $\begin{array}{l}80 \\
\frac{76}{73} \\
75 \\
75\end{array}$ & $\begin{array}{l}80 \\
83 \\
75 \\
80 \\
77 \\
80\end{array}$ & $\begin{array}{l}84 \\
\frac{84}{80} \\
\frac{80}{81}\end{array}$ & $\begin{array}{l}81 \\
\frac{83}{82} \\
\frac{81}{82}\end{array}$ & $\begin{array}{l}85 \\
\frac{82}{87} \\
\frac{87}{83}\end{array}$ & $\begin{array}{l}83 \\
83 \\
80 \\
80 \\
77 \\
77\end{array}$ \\
\hline
\end{tabular}

Table 7. Sphericity of the sandparticles in the North-Eastern Polder, estimated according to Rittenhouse.

VERVELDE acht zelfvergiftiging van de wortels, in lagen waarin de groei om de een of andere reden reeds langzaam gaat, een mogelijkheid van totale stilstand in de groei. Dit kan voor de zandgronden die met een zeer laag lutum- en/of humusgehalte zeer slecht gebufferd zijn, inderdaad een oorzaak zijn van de gehele stilstand, echter niet van de voorafgaande remming.

De betekenis van het wortelbeeld voor de opbrengst der gewassen

In de inleiding werd reeds vermeld, dat GoEDEwAaGen (1955) een zeer goed gewas winterkoolzaad aantrof in de Noordoostpolder bij een bewortelingsdiepte van $20 \mathrm{~cm}$. Overeenkomstige ervaringen worden $\mathrm{nu}$ opgedaan met de eerste gewassen in het in 1957 drooggevallen Oostelijk Flevoland. In oudere grond zou een dergelijke bewortelingsdiepte zonder kunstmatige wateraanvoer verdroging van het gewas tot gevolg hebben.

SchuURMan en Makkink vonden bij een onderzoek naar de beworteling op een beregeningsproefveld, dat de beregende veldjes een geringere wortelmassa hadden dan de niet beregende, terwijl de grasproduktie hoger was.

Van 69 luzernekavels in de Noordoostpolder waren over de jaren 1948, 1949 en 1950 de opbrengsten en de bewortelingsdiepten bekend. De correlatie-coëfficiënt tussen opbrengst en bewortelingsdiepte bedroeg 0.12 , hetgeen inhoudt dat de samenhang tussen toenemende diepte en hogere opbrengst te verwaarlozen is.

Uit het voorgaande volgt, dat de omvang van het wortelstelsel wordt bepaald door het bodemprofiel, en daar de plant de voor de groei benodigde stoffen aan dat profiel moet onttrekken, moet hier- 
uit volgen dat de opbouw en geaardheid van het profiel bepalend is voor de gewasgroei. Dit sluit geheel aan bij de opvattingen van PIJLs, KaLIsVAART en VISSER over de waardering van de grond.

In de Inleiding werd onder meer als doel van het bewortelingsonderzoek in de Noordoostpolder gesteld: het onderzoeken van de mogelijkheden om in de verschillende profielen door geschikte grondbewerkingen de gelegenheid te scheppen voor een uitgebreid en diep groeiend wortelstelsel van de landbouwgewassen.

Hierbij werd verondersteld, dat een diepgaand wortelstelsel nodig is voor een goede gewasontwikkeling. Deze gedachtengang is niet onjuist, maar onvolledig. Een ondiep wortelstelsel kan evengoed als een diepgaand wortelstelsel voor de opneming van voldoende voedingsstoffen zorgen, mits deze slechts in de doorwortelde ruimte genoegzaam ter beschikking staan (en de hoeveelheid wortels, door te weinig ruimte, niet zozeer wordt beperkt, dat de opnemingscapaciteit van de wortels onvoldoende is). Dit laatste is niet altijd te verwezenlijken, ofschoon een kunstmatige watervoorziening (hetzij door infiltratie, hetzij door beregening) reeds in vele gevallen wordt toegepast.

VELDMAN toonde aan, dat een doorwortelbare diepte van $70 \mathrm{~cm}$ in een zavelgrond voldoende moet worden geacht om $90 \%$ van de normale produktie van de landbouwgewassen te bereiken, indien de planten voor hun vochtvoorziening uitsluitend op het in het profiel aanwezige hangwater zijn aangewezen. Elke grotere bewortelingsdiepte betekent een grotere zekerheid, dat geen verdroging zal optreden.

Aan de behoefte aan voedingsstoffen kan door bemesting worden voldaan.

De betekenis van het wortelbeeld is daarom van tweeërlei aard. In de eerste plaats geeft het aan welke mogelijkheden het profiel biedt aan de plant voor de beworteling, en in de tweede plaats hoe de plant gebruik maakt van het profiel. De aard van het profiel is echter bepalend voor de gewasgroei. 


\section{Inleiding}

De opbouw van de meeste bodemprofielen in de Noordoostpolder wijkt af van het homogene zavelprofiel dat als uitgangspunt is genomen voor de beschrijving van de "normale" wortelstelsèls der landbouwgewassen. Gezien de invloed welke verschillende onderdelen van deze profielen op de beworteling kunnen uitoefenen, moet worden verwacht, dat de beworteling in een aantal gevallen niet "normaal" is. Ofschoon een afwijking geen direct nadeel voor de groei der gewassen behoeft in te houden, is het toch zeer wenselijk, dat de invloed van de verschillende profielen op de beworteling bekend is. Zo nodig kan dan worden overwogen, of een verbetering moet worden aangebracht en, zo ja, op welke wijze dit dient te geschieden.

Daarnaast is het wenselijk, dat inzicht wordt verkregen in de veran. deringen die de bodemprofielen hebben ondergaan gedurende de periode dat de Noordoostpolder bestaat. In een aantal gevallen, o.a. betrekking hebbend op de sloef, werd aanvankelijk een zeer trage aëratie opgemerkt, waardoor een diepgaand wortelstelsel zich niet kon ontwikkelen. Door ingrijpen (ondergrondbewerking) werd de aëratie en daardoor de beworteling verbeterd. Indien nu bekend is, dat dergelijke profielen op den duur „,vanzelf" beter worden, kan worden overwogen de ondergrondbewerking achterwege te laten. Hierbij dienen overeenkomstige profielen die wel en die geen ondergrondbewerking hebben ondergaan, te worden vergeleken.

Voor het onderzoek werd een indeling van de profieltypen in de Noordoostpolder gemaakt, die grotendeels gebaseerd is op de indeling van SiEben. Deze indeling berust op het voorkomen in boven- en ondergrond van zware en lichte zavel, zand en veen. Ofschoon binnen deze vier grondsoorten nog tal van variaties voorkomen, bieden zij voldoende mogelijkheid tot een indeling.

Het schema op blz. 70/71 geeft de profielen weer. Deze indeling is in de praktijk zeer hanteerbaar gebleken.

„Zwaar op zwaar" betekent een bodemprofiel dat geheel uit zware zavel- of kleilagen is opgebouwd.

„Zwaar op licht" stelt een bodemprofiel voor, bestaande uit een zware zavellaag van variërende dikte op een ondergrond van lichte zavel, zand of sloef. 
„Licht op zwaar" stelt een bodemprofiel voor met een bovengrond van lichte zavel of zand op een ondergrond van zware zavel of klei.

"Licht op licht" stelt een bodemprofiel voor met een bovengrond van lichte zavel of zand op een ondergrond van lichte zavel of zand. Deze groep is in tweeën verdeeld. De eerste ondergroep komt voornamelijk in het westen van de polder voor, waar in de bovengrond vaak Espelzand aanwezig is en in de ondergrond zandige sloef: De tweede ondergroep bestaat over de gehele diepte uit dezelfde zandsoort.

De vijfde groep heeft veen of detritus-gyttja in de ondergrond onder een zand- of zavellaag van uiteenlopende dikte.

De onderverdeling der groepen berust op een verdergaande onderscheiding van de grondsoorten volgens lutumgehalte, wijze van afzetting (sloef), fijnheid van het zand, onderscheid tussen veensoorten en aan wezigheid van kwel of infiltratie.

Het onderzoek, verricht in 1955 en 1956, geschiedde met behulp van naaldenplanken. Deze waren zo groot $\left(35 \times 13 \times 70 \mathrm{~cm}^{3}\right)$, dat de beworteling tot $70 \mathrm{~cm}$ diepte kon worden bemonsterd. Voor de meeste profielen was deze diepte voldoende; slechts bij enkele reikten de wortels dieper. Hierbij werden de monsters evenwijdig an de rijen genomen.

Zoveel mogelijk werd de beworteling van wintertarwe onderzocht. Waar dit gewas op de lichtere gronden niet werd verbouwd, werd de beworteling van zomertarwe of haver genomen.

$\mathrm{Na}$ het uitspoelen werd het wortelbeeld gefotografeerd. Daarna werden de wortels in lagen van $10 \mathrm{~cm}$ diepte verdeeld, gedroogd en gewogen.

Wegens de omvang van dit werk werd van elk profiel slechts eenmaal een naaldenplankmonster genomen, zodat de onnauwkeurigheid van de enkelvoudige waarneming moest worden geaccepteerd. De oorzaak van deze onnauwkeurigheid ligt vooral in de bouwvoor, waar de wortelontwikkeling sterker dan in de ondergrond kan worden beïnvloed door grondbewerking, bemesting, verpleging, klimaat en andere van buiten af werkende invloeden. Het is dus het eenvoudigst om bij het onderzoek . de beworteling in de bouwvoor buiten beschouwing te laten en de aandacht te bepalen tot de verdeling van de wortels in de ondergrond.

Daardoor kan de omrekening van de wortelhoeveelheid in de bouw. voor, die wel voor wintertarwe is onderzocht, maar niet voor zomertarwe en haver, achterwegeblijven.

Bij een vergelijking van de wortelverdelingen over de profielen spelen ook de wortelgewichten geen rol meer, zodat hierdoor het gebruik van verschillende gewassen eveneens minder bezwaren heeft.

De verdeling van de beworteling over het profiel onder de bouwvoor is, blijkens de wortelhoevelheden in fig. 5, minder aan wisselingen onderhevig dan de hoeveelheden in de bouwvoor.

De wortelverdeling werd berekend door de hoeveelheid wortels in elke $10 \mathrm{~cm}$ dikke laag uit te drukken in procenten van de totale, in de laag van $20-70 \mathrm{~cm}$ diepte voorkomende, hoeveelheid wortels.

Om een indruk te verkrijgen van de hoeveelheid wortels; wordt het 
Profiel typen ir

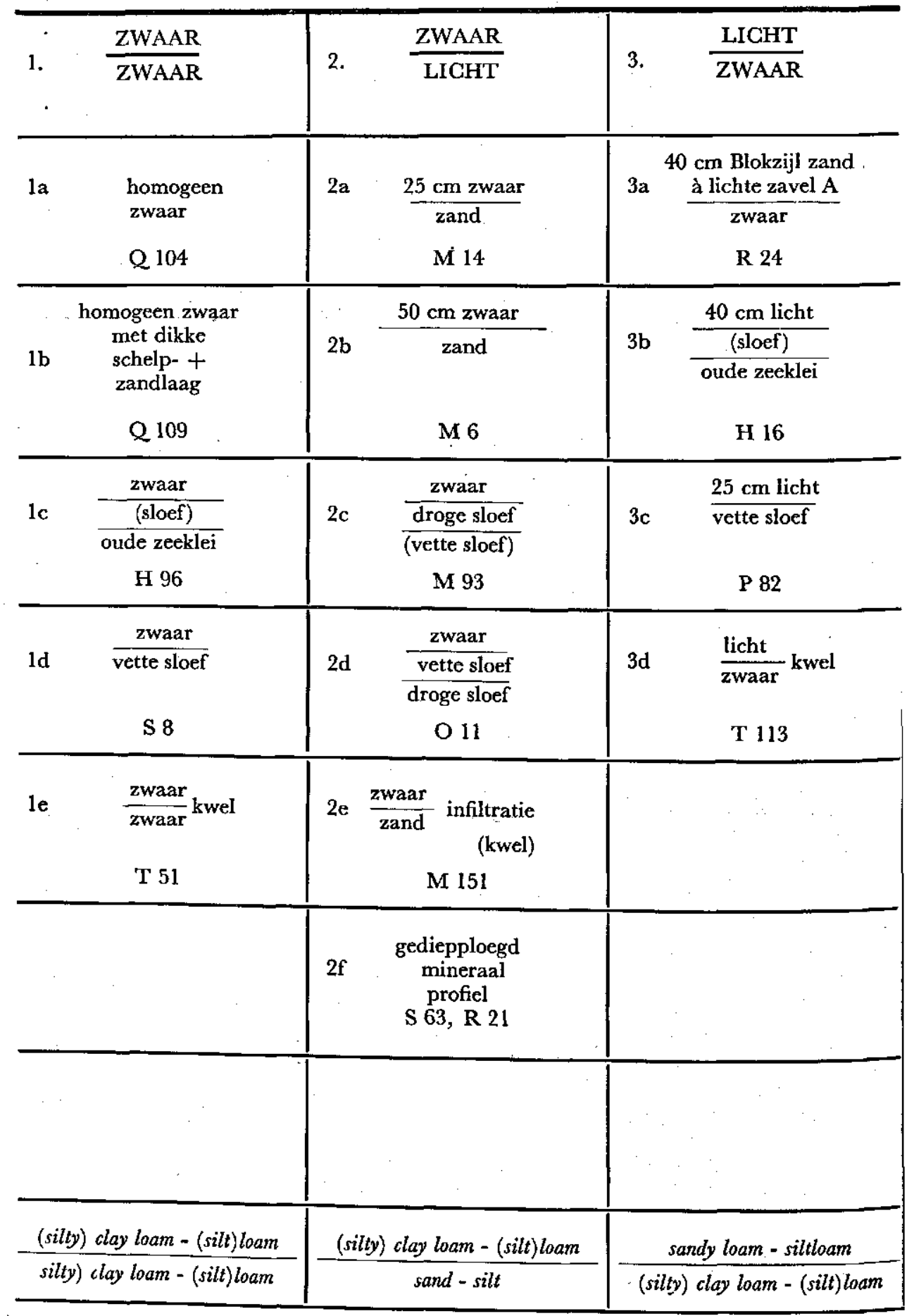


de Noordoostpolder

\begin{tabular}{|c|c|c|c|c|}
\hline $\begin{array}{l}\text { 4. } \frac{\text { LICHT }}{\text { LICHT }} \\
\text { zand en zavel }\end{array}$ & & $\begin{array}{l}\frac{\text { LICHT }}{\text { LICHT }} \\
\text { homogeen zand }\end{array}$ & \multicolumn{2}{|c|}{$\begin{array}{l}\text { 5. VEEN/DETRITUS } \\
\text { in de ondergrond }\end{array}$} \\
\hline $\begin{array}{l}4 a \frac{\text { Espelzand }}{\text { sloef }} \frac{\text { (Espelzand) }}{\text { (lichte zavel A) }} \\
\text { B } 42\end{array}$ & $4 b$ & $\begin{array}{c}\frac{\text { stortgrond }}{\text { pleistoceenzand }} \\
\text { F } 38\end{array}$ & & $\begin{array}{c}\frac{25 \mathrm{~cm} \text { zavel }}{\text { veen }} \\
\text { A } 69\end{array}$ \\
\hline $\begin{array}{c}4 \mathrm{a}^{1} \frac{\frac{\text { lichte zavel } \mathrm{A}}{\text { Espelzand }}}{\text { zandige sloef }} \\
\text { B } 53\end{array}$ & $4 c$ & $\begin{array}{c}\text { homogeen } \\
\text { Blokzijlzand } \\
\text { R } 75\end{array}$ & $5 a^{1}$ & $\begin{array}{c}\frac{25 \mathrm{~cm} \text { zavel }}{\text { detritus }} \\
\text { A } 76\end{array}$ \\
\hline $\begin{array}{c}4 \mathrm{a}^{11} \frac{\text { lichte zavel A }}{\text { Espélzand }} \\
\text { sloef (lichte zavel A) } \\
\text { C } 60\end{array}$ & $4 d$ & $\begin{array}{l}\frac{\text { homogeen }}{\text { Ramspolzand }} \\
\text { (infiltratie) } \\
\text { P } 64\end{array}$ & $5 b$ & 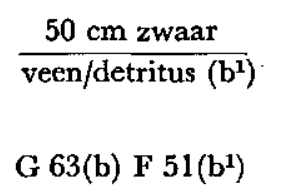 \\
\hline 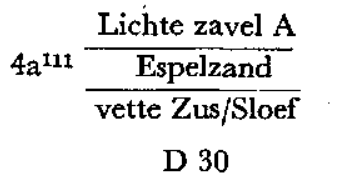 & $4 e$ & $\begin{array}{c}\text { Blokzijlzand } \\
\text { met schelp- } \\
\text { bank } \\
\text { K } 10\end{array}$ & $5 c$ & $\begin{array}{l}\frac{50 \mathrm{~cm} \text { licht }}{\text { veen/detritus }\left(\mathrm{c}^{1}\right)} \\
\text { B } 102(\mathrm{c}), \text { C } 93\left(\mathrm{c}^{1}\right)\end{array}$ \\
\hline \multirow[t]{3}{*}{$\begin{array}{c}4 \mathrm{a}^{1111} \quad \text { lichte zavel } \mathrm{B} \\
\text { vrij vette sloef } \\
\text { C } 121,131\end{array}$} & $4 \mathrm{f}$ & $\begin{array}{l}\overbrace{\text { licht }}^{\text {licht }} \text { kwel } \\
\text { A } 14 \text { e.o. }\end{array}$ & & $\begin{array}{c}\frac{\text { zavel Kwel }}{\text { veen infiltratie }} \\
\text { A } 8\end{array}$ \\
\hline & & $\begin{array}{c}\underset{\text { Urk-Kuinre ) }}{\text { Urkeen ) }} \begin{array}{l}\text { in- } \\
\text { fil- } \\
\text { tratie }\end{array} \\
\text { zand }\end{array}$ & & $\begin{array}{l}\text { gediepploegd } \\
\frac{\text { zand }}{\text { veen }} \\
\text { K } 40\end{array}$ \\
\hline & & $\cdot$ & $5 \mathrm{e}^{\mathbf{x}}$ & $\begin{array}{l}\text { gediepploegd } \\
\frac{\text { venig }}{\text { mineraal }} \\
\text { E } 10\end{array}$ \\
\hline sandy loam - silt loam & \multicolumn{2}{|c|}{ coarse sand to silt (loam) } & \multirow{2}{*}{\multicolumn{2}{|c|}{$\begin{array}{l}\text { peat or pulverized peat } \\
\text { to gvttja in the subsoil }\end{array}$}} \\
\hline sandy loam - sill loam & & arse sand to silt (loam) & & \\
\hline
\end{tabular}

North-Eastern Polder. 
gewicht vermeld, yoorkomende in een blok van $10 \times 23 \times 50 \mathrm{~cm}^{3}$ (dus van $10 \mathrm{~cm}$ rijlengte, $23 \mathrm{~cm}$ rijafstand en $20-70 \mathrm{~cm}$ diepte).

De verdeling der wortels in lagen van $10 \mathrm{~cm}$ dikte wordt dus onafhankelijk van de profielopbouw gehouden. De invloed van de verschillende lagen is daardoor niet uit de gegevens af te leiden.

Ter toelichting van de berekening mogen de volgende gegevens dienen. In 1955 werden op kavel D 30 naaldenplankmonsters genomen van winter- en zomertarwe en van haver, op betrekkelijk geringe onderlinge afstand. Op de kavels D 21 en $Q 104$ werden eveneens naaldenplankmonsters van wintertarwe genomen. In 1957 werden bovendien nog twee haverrassen en twee zomertarwerassen telkens vijfmaal bemonsterd op dicht bij elkaar gelegen plaatsen (rassen-proefveld).

In tabel 8a staan de gegevens vermeld over de van de naaldenplanken verkregen wortelhoeveelheden in $\mathrm{mg}$ per laag, en in tabel $8 \mathrm{~b}$ de procentuele verdelingen over de lagen en de hoeveelheid wortels in $\mathrm{mg}$. in de laag $20-70 \mathrm{~cm}$.

Al deze profielen zijn goed doorwortelbaar, hetzij van nature (zoals op kavel $Q 104$ ), hetzij kunstmatig (zoals de losgemaakte zandige profielen van de kavels D 21, D 22 en D 30).

$\mathrm{Er}$ is voldoende overeenstemming tussen de verschillende profielen ten aanzien van de winter- en zomertarwe op kavel D 30 (fig. 37 en 38). De invloed van het profiel is merkbaar op kavel Q 104 (vgl. Q 110 fig. 20), waar de beworteling 30 a $40 \mathrm{~cm}$ dieper reikte, in tegenstelling tot de andere kavels, waar $70 \mathrm{~cm}$ ongeveer de dieptegrens was.

De wortelverdeling van de haver wijkt op kavel D 30 duidelijk af van die van de tarwes (fig. 39). De hoeveelheid wortels neemt beneden $40 \mathrm{~cm}$ snel af. Dat hier een ras-invloed aanwezig kan zijn, tonen de wortelverdelingen van het lange en het korte haverras op kavel D 22 aan (fig. 40 en 41). Het korte ras heeft hier beneden $30 \mathrm{~cm}$ diepte een geringere wortelontwikkeling dan het lange ras (dit waren respectievelijk het kortste en het langste ras, op het proefveld aanwezig, beide ongeveer tegelijk afgerijpt). Het haverras op kavel D 30 . was een ander dan het korte op $\mathrm{D} 22$. De wortelverdeling van het langste ras komt goed overeen met de wortelverdeling van de zomertarwe op dezelfde kavel.

Tussen het korte en het lange zomertarweras is geen verschil in beworteling opgemerkt.

Zowel de betrouwbaarheid als de onbetrouwbaarheid komt tot uiting in deze cijfers. Voor een goede beoordeling is de kennis van de rasinvloed op de beworteling dus ten zeerste vereist, zodra bij een onderzoek noodgedwongen met verschillende rassen moet worden gewerkt.

Slechts in het geval van de haver is bekend, dat er een rasinvloed bestaat; voor de wintertarwe en de zomertarwe is deze niet bekend, a] is hij vermoedelijk wel aanwezig, 
TABEL 8a. Wortelhoeveelheden van verschillende granen (in $\mathrm{mg}$ drogestof) in opeenvolgende lagen van $10 \mathrm{~cm}$ dikte in blokken van $35 \times 13 \times 10 \mathrm{~cm}^{3}$, genomen evenwijdig aan de rij.

\begin{tabular}{|c|c|c|c|c|c|c|c|c|c|}
\hline $\begin{array}{c}\text { Kavel } \\
\text { Plot }\end{array}$ & D 30 & D 30 & D 30 & $Q_{104}$ & D 21 & D 22 & D 22 & D 22 & D 22 \\
\hline $\begin{array}{c}\text { Datum } \\
\text { Date }\end{array}$ & $19-8-55$ & $19-8-55$ & $25-8-55$ & $27-6-55$ & $5-7-55$ & $25-7-57$ & $30-7-57$ & $3-8-57$ & $2-8-57$ \\
\hline Gewas & $\begin{array}{l}\text { Winter- } \\
\text { tarwe }\end{array}$ & $\begin{array}{l}\text { Zomer- } \\
\text { tarwe }\end{array}$ & Haver & $\begin{array}{l}\text { Winter- } \\
\text { tarwe }\end{array}$ & $\begin{array}{c}\text { Winter- } \\
\text { tarwe }\end{array}$ & 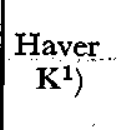 & $\begin{array}{c}\text { Haver } \\
\left.\mathbf{L}^{1}\right)\end{array}$ & $\begin{array}{l}\text { Zomer- } \\
\text { tarwe } \\
\left.\mathrm{K}^{\mathbf{1}}\right)\end{array}$ & $\begin{array}{c}\text { Zomer- } \\
\text { tarwe } \\
\left.\mathbf{L}^{1}\right)\end{array}$ \\
\hline Crop & $\begin{array}{c}\text { Winter, } \\
\text { wheat }\end{array}$ & $\begin{array}{l}\text { Spring- } \\
\text { wheat }\end{array}$ & Oats & $\begin{array}{c}\text { Winter- } \\
\text { wheat }\end{array}$ & $\begin{array}{c}\text { Winter- } \\
\text { wheat }\end{array}$ & Oats & Oats & $\begin{array}{l}\text { Spring- } \\
\text { wheat }\end{array}$ & $\begin{array}{l}\text { Spring- } \\
\text { wheat }\end{array}$ \\
\hline $0-10 \mathrm{~cm}$ & 3042 & 2269 & 2485 & 5000 & 8234 & 4512 & 4926 & 2648 & 2882 \\
\hline $10-20$ & 385 & 403 & 712 & 440 & 1098 & 629 & 847 & 430 & 270 \\
\hline $20-30$ & 358 & 558 & 653 & 290 . & 546 & $\ldots 715$ & 779 & 466 & 384 \\
\hline $30-40$ & 263 & 344 & 186 & 190 & 467 & 366 & 679 & 411 & 356 \\
\hline $40-50$ & 108 & 231 & 70 & 180. & 565 & 185 & 424 & 231 & 260 \\
\hline $50-60$ & 106 & 220 & 24 & 280 & 413 & 107 & 325 & 198 & 202 \\
\hline $60-70$ & 86 & 68 & 14 & 300 & 154 & 42 & 139 & $7 !$ & 67 \\
\hline $20-70$, & 921 & 1421 & 947 & 1240 & 2145 & 1415 & 2346 & 1377 & 1269 \\
\hline
\end{tabular}

1) $\mathrm{K}$ en $\mathrm{L}$ betekenen resp. een kort en een lang ras van het betrokken gewas.

$K$ or $L$ means a short or a long varizty of the crop.

TABLE 8a: Amounts ( $m g$ dry matter) of roots of some cereals in successive layers; thick $10 \mathrm{~cm}$, in blocks of $35 \times 13 \times 10 \mathrm{~cm}^{3}$. The root samples are taken with a pin board; parallel with the crop rows.

$T_{A B E L} 8 \mathrm{~b}$. De onderlinge verhouding (\%) van de wortelhoeveelheden van de tabel $8 \mathrm{a}$, uitgedrukt in de totale hoeveelheid wortels voorkomende in de laag van $20-70 \mathrm{~cm}$ diepte, en de hoeveelheden wortels (in mg droge stof) in een blok van $10 \times 23 \times$ $\times 50 \mathrm{~cm}^{3}$.

\begin{tabular}{l|r|r|r|r|r|r|r|r|r}
\hline $20-30 \mathrm{~cm}$ & 39 & 39 & 69 & 23 & 26 & 51 & 33 & 34 & 30 \\
$30-40$, & 29 & 24 & 20 & 15 & 22 & 26 & 29 & 30 & 28 \\
$40-50$, & 12 & 16 & 7 & 15 & 26 & 13 & 18 & 17 & 21 \\
$50-60$ & 12 & 16 & 3 & 23 & 19 & 8 & 14 & 14 & 16 \\
$60-70 "$ & 9 & 5 & 2 & 24 & 7 & 3 & 6 & 5 & 5 \\
$20-70 "$ & $465 \mathrm{mg}$ & $718 \mathrm{mg}$ & $478 \mathrm{mg}$ & $626 \mathrm{mg}$ & $1083 \mathrm{mg}$ & $715 \mathrm{mg}$ & $1185 \mathrm{mg}$ & $695 \mathrm{mg}$ & $641 \mathrm{mg}$ \\
\hline
\end{tabular}

TABLE 8b. Proportions between the amounts of roots from table $8 a$, as percentage of the total amount in the layer $20-70 \mathrm{~cm}$, and the amount ( $\mathrm{mg}$ dry matter) of roots in a block $10 \times 23 \times 50 \mathrm{~cm}^{3}$ $(10 \mathrm{~cm}$ length of row, $23 \mathrm{~cm}$ distance between two rows, $50 \mathrm{~cm}$ depth from $20-70 \mathrm{~cm}$ below soil level). 
Het profieltype zwaar op zwaar

De typen la, lb en le hebben in de boven- en de ondergrond zware zavel. De verschillen ontstaan door een zandlaag op de scheiding in type $1 b$ en door het voorkomen van kwel in type le.

In de typen 1c en ld komt in de ondergrond resp. oude zeeklei en vette sloef voor, welke geen van beide gemakkelijk rijpen.

De wortelverdeling in de ondergrond is als volgt:

TABEL 9. Wortelverdelingen $(\%)$ in het profieltype 1 , zwaar op zwaar, en de totale hoeveelheden wortels (in $\mathrm{mg}$ droge stof) in blokken van $10 \times 23 \times 50 \mathrm{~cm}^{3}$.

\begin{tabular}{c|c|c|c|c|c|c}
\hline Type & Ia & la/b & lb & lc & ld & le \\
\hline Kavel & Q 104 & Q 110 & Q 109 & H 96 & S 8 & T 51 \\
\hline Datum & $27-6-55$ & $2-8-' 56$ & $27-6-' 55$ & $27-8-' 55$ & $10-8-' 56$ & $10-8-56$ \\
\hline Gewas & \multicolumn{5}{|c}{ Wintertarwe } \\
\hline $20-30 \mathrm{~cm}$ & 23 & 19 & 50 & 30 & 35 & 18 \\
$30-40 "$ & 15 & 14 & 19 & 39 & 37 & 24 \\
$40-50, "$ & 15 & 20 & 17 & 26 & 18 & 25 \\
$50-60, "$ & 23 & 23 & 11 & 4 & 6 & 25 \\
$60-70 "$ & 24 & 24 & 3 & sp. & 3 & 8 \\
$20-70 \mathrm{~cm}$ & $626 \mathrm{mg}$ & $893 \mathrm{mg}$ & $322 \mathrm{mg}$ & $342 \mathrm{mg}$ & $434 \mathrm{mg}$ & $553 \mathrm{mg}$ \\
\hline
\end{tabular}

1a. De profielen la en la/b (fig. 20) hebben op ongeveer $40 \mathrm{~cm}$ diepte een dunne zandlaag, welke door haar plaats tussen twee zware lagen niet hinderlijk is. Een soortgelijk profiel op $N 58$ was in 1947 tot $\pm 85 \mathrm{~cm}$ doorworteld. In 1956 gingen de wortels nog dieper, n.l. tot $\pm 110 \mathrm{~cm}$.

H 96 (fig. 43) op $50 \mathrm{~cm}$ diepte beginnen, vertonen enkele brede laag, welke de beworteling iets tegenhoudt. Op deze kavel toonde de haverbeworteling in 1956 grote overeenkomst met de beworteling van de haver op D 30 en die van de korte haver op D 22 (tabel 8b).

1c. De humeuze Cardium-klei en de zware Cardium-klei, welke op H 96 (fig. 43) op $50 \mathrm{~cm}$ diepte beginnen, vertonen enkele brede scheuren, waarin wortels zijn. De klei zelf is niet doorworteld. Sinds 1949 , toen voor de eerste maal de beworteling in dit profiel werd opgenomen, is er vermoedelijk weinig veranderd. Daar de ondergrond van deze kavel zeer bont is, werd niet hetzelfde profiel gevonden. Luzerne-wortels werden alleen in de scheuren aangetroffen. De aëratie in deze zware klei is op het oog niet te bepalen, doch vermoedelijk zeer gering. 
Id. Het profiel van S 8 (fig. 42) behoort, door de lichte zavel $\mathrm{B}$ in de ondergrond, eigenlijk thuis in type 2, zwaar op licht. Het komt in geaardheid echter overeen met type lb. De zandlaag is betrekkelijk dik, de ondergrond echter iets lichter. De lichte zavel, welke op $50 \mathrm{~cm}$ diepte begint, vormt een grotere belemmering voor de wortels dan de zandlaag. Het gelaagde karakter van deze lichte zavel (Zus) is vermoedelijk de oorzaak.

le. Het profiel van $T 51$, zwaar op zwaar, is in de bovengrond zwaarder dan op Q 104; de zandlaag ontbreekt. In goede ontwateringstoestand zou er een grote overeenkomst met deze kavel zijn. De aanwezigheid van kwel houdt de aëratie tegen. Beneden $60 \mathrm{~cm}$ diepte is de aëratie onvolledig en neemt de wortelmassa snel af. Sinds 1949 is de aëratie op deze kavel iets vooruitgegaan.

Over het geheel genomen is er ten aanzien van de beworteling in de genoemde profielen weinig veranderd. Voor zover er veranderingen zijn, kunnen deze worden toegeschreven aan de langzame veranderingen die doorgaan, nadat de snelle aëratie van de begintoestand is afgelopen, met als gevolg een betere doorworteling.

\section{Het profieltype zwaar op licht.}

De typen $2 \mathrm{a}$ en $2 \mathrm{~b}$ en $2 \mathrm{e}$ bestaan uit een zavellaag van uiteenlopende dikte, rustend op een zand-ondergrond. Indien de zavellaag dun is, kan de vochtvoorziening van het gewas vaak met behulp van infiltratie worden geregeld.

De typen $2 c$ en $2 d$ hebben onder de zavellaag verschillende sloeflagen.

TABEL 10. Wortelverdelingen (\%) in het profieltype 2, zwaar op licht, en de totale hoeveelheden wortels (in $\mathrm{mg}$ droge stof) in een blok van $10 \times 23 \times 50 \mathrm{~cm}^{3}$.

\begin{tabular}{|c|c|c|c|c|c|c|c|}
\hline Type & $2 a$ & $2 \mathrm{~b}$ & $2 c$ & $2 d$ & $2 e$ & $2 \mathrm{f}$ & $2 \mathrm{f}$ \\
\hline Kavel & M 14 & M 6 & M 93 & O 11 & M 151 & S 63 & R 21 \\
\hline Datum & $11-8-55$ & $11-8-' 55$ & $12-8-55$ & $19-8-' 55$ & $22-8-' 55$ & $11-8-' 55$ & $11-8-55$ \\
\hline Gewas & \multicolumn{6}{|c|}{ Wintertarwe } & $\begin{array}{c}\text { Zomer- } \\
\text { tarwe }\end{array}$ \\
\hline $\begin{array}{l}20-30 \mathrm{~cm} \\
30-40 \quad " \\
40-50 \quad " \\
50-60 \quad " \\
60-70 "\end{array}$ & $\begin{array}{r}34 \\
23 \\
21 \\
21 \\
1\end{array}$ & $\begin{array}{r}21 \\
30 \\
27 \\
15 \\
7\end{array}$ & $\begin{array}{r}27 \\
30 \\
26 \\
11 \\
7\end{array}$ & $\begin{array}{r}36 \\
40 \\
14 \\
10 \\
1\end{array}$ & $\begin{array}{r}36 \\
34 \\
27 \\
4 \\
0\end{array}$ & $\begin{array}{r}34 \\
24 \\
24 \\
14 \\
5\end{array}$ & $\begin{array}{r}44 \\
22 \\
18 \\
8 \\
8\end{array}$ \\
\hline $20-70 \mathrm{~cm}$ & $828 \mathrm{mg}$ & $188 \mathrm{mg}$ & $495 \mathrm{mg}$ & $268 \mathrm{mg}$ & $328 \mathrm{mg}$ & $355 \mathrm{mg}$ & $203 \mathrm{mg}$ \\
\hline
\end{tabular}


Deze sloeflagen kunnen behoren tot de lichte zavel indien het lutumgehalte voldoende hoog is, en tot de zandgronden indien het lutumgehalte laag is.

Het type $2 \mathrm{f}$ is een kunstmatig profiel, ontstaan door het diepploegen van een profiel zand op zavel. Ofschoon enige vermenging hierbij niet is te voorkomen, kan het profiel na het diepploegen tot deze groep worden gerekend.

De wortelverdeling in de ondergrond is weergegeven in tabel 10.

2a. Op M 14 (fig. 44) ligt de grens zavel-zand op ongeveer $30 \mathrm{~cm}$ diepte. Dit is in de bewortelingsdichtheid nauwelijks te merken. De laag zand tot ongeveer.65 $\mathrm{cm}$ diepte was matig vochtig. Dieper werd het zand zeer nat en waren slechts enkele.wortels aanwezig. Een overeenkomstig profiel op M 81 toonde in 1947 ook reeds enkele wortels in de bovenste zandlagen. Ook op andere plaatsen bleek toen, dat, indien in het zand een min of meer volledig A-B-Cprofiel aanwezig was, de beworteling beter doordrong in de A- en B-horizonten dan in de onderliggende C-horizont، Op M 14 is door het losmaken van de bovenste zandlagen de doorworteling sterk verbeterd.

2b. Op M 6 ligt de zavel-zandgrens op ongeveer $45 \mathrm{~cm}$ diepte, met als gevolg dat deze overgang in het cijfer-materiaal niet tot uiting komt. De onder de zavel liggende A- en A-C-horizonten zijn naar verhouding vrij goed doorworteld alhoewel de totale wortelhoeveelheid laag is.

2e. Het witte zand (C-horizont) op $\mathrm{M} 151$ is niet toegankelijk voor de wortels, zoals de sterke daling van de wortelhoeveelheid aantoont. De overgang bevindt zich op $\pm 50 \mathrm{~cm}$.

2c en $2 \mathrm{~d}$. De profielen op M 93 en 0.11 met sloef in de ondergrond verschillen in de volgorde van zavelige en zandige sloef (vette en droge sloef). Op M 93 ligt de zandige (droge) sloef boven; op O 11 de zavelige (vette) sloef. Vermoedelijk omdat $O 11$ als geheel wat aan de natte kant was, is de wortelhoeveelheid daar laag. De vette humeuze sloef op deze kavel was vrij goed gescheurd. De doorworteling was echter matig. Op M 93, met de vette sloef onderin, was de beworteling zeer regelmatig en niet 'beinvloed door de droge sloef. De aard van deze sloef was hier dus niet ongunstig. De aëratiegrens op beide kavels lag op $\pm 70 \mathrm{~cm}$.

In 1947 en 1948 was de aëratie in overeenkomstige profielen niet verder gevorderd dan tot de Zu III-laag, die boven de sloeflagen ligt. In die tijd werd reeds waargenomen, dat de vette sloef iets meer neiging had tot scheurvorming dan de droge. De rijping is sindsdien dus goed gevorderd, maar bereikt op deze kavels nog niet de $100 \mathrm{~cm}$ diepte van de goede homogene zavelprofielen. Dit komt tevens tot uiting in het ontbreken van wortels in de droge sloef onder in het profiel op $\mathrm{O} 11$. 
2f. De door diepploegen verkregen profielen op $S 63$ (fig. 45) en R 21 hebben een bouwvoor van lichte zavel. Deze rust op $S .63$ op een mengsel van Blokzijlzand en lichte zavel. Op $R$ 2'l begint dit mengsel pas op ongeveer $40 \mathrm{~cm}$ diepte; hier bestaat het mengsel echter uit veel Blokzijlzand en weinig lichte zavel. De aëratie is op $S 63$ gevorderd tot $85 \mathrm{~cm}$, op $R 21$ tot $70 \mathrm{~cm}$. Het nattere karakter (kwel) van $R 21$ komt zowel tot uiting in de geringe aëratiediepte als in de minder goede doorworteling van het Blokzijlzandmengsel.

\section{Het profieltype licht op zwaar}

De profielen van deze groep zijn op dezelfde wijze ingedeeld als van de groep zwaar op zwaar. In de ondergrond komen dus voor: zware zavel, zeeklei, vette sloef en zware zavel met kwel. Daar de doorwortelbaarheid van de bovenste lagen in de regel vrij goed is (afgezien van bouwvoorstoornissen), moeten deze twee groepen, wat de beworteling betreft met elkaar overeenkomen.

TABEL 11. Wortelverdelingen (\%) in het profieltype 3, licht op zwaar, en de totale hoeveelheden wortels (in $\mathrm{mg}$ droge stof) in blokken van $10 \times 23 \times 50 \mathrm{~cm}^{3}$.

\begin{tabular}{c|c|c|c|c}
\hline Type & $3 \mathrm{a}$ & $3 \mathrm{~b}$ & $3 \mathrm{c}$ & $3 \mathrm{~d}$ \\
\hline Kavel & R 24 & H 16 & P 82 & T 113 \\
\hline Datum & $22-8-56$ & $26-8-' 55$ & $27-8-55$ & $27-8-55$ \\
\hline Gewas & \multicolumn{4}{|c}{ Wintertarwe } \\
\hline $20-30 \mathrm{~cm}$ & 20 & 44 & 19 & 27 \\
$30-40 \%$ & 13 & 26 & 26 & 30 \\
$40-50 \%$ & 15 & 15 & 28 & 21 \\
$50-60 \%$ & 23 & 10 & 23 & 14 \\
$60-70-$ & 30 & 5 & 4 & 9 \\
$20-70 \mathrm{~cm}$ & $336 \mathrm{mg}$ & $294 \mathrm{mg}$ & $637 \mathrm{mg}$ & $262 \mathrm{mg}$ \\
\hline
\end{tabular}

3a. De bouwvoor op R 24 bestaat uit Blokzijlzand, rustend op een lichte zavel. Op $\pm 35 \mathrm{~cm}$ begint de zware zavel, waaronder de nog zwaardere lichte kIei van de $\mathrm{Zu}$ II. Het profiel was slechts geaëreerd tot $80 \mathrm{~cm}$ (vermoedelijk als gevolg van kwel); hetgeen eigenlijk niet diep genoeg is. De doorworteling wordt naar beneden beter, in overeenstemming met profieltype la. 
3b. De zeeklei in de ondergrond van $\mathrm{H} 16$ (fig. 46) is van andere aard dan op $\mathrm{H}$ 96. Het is de kweldervorm van de Unioklei, hetgeen inhoudt dat deze klei tijdens en na zijn afzetting begroeid is geweest. Dit komt nu tot uiting door een vrij goede beworteling, die slechts afneemt in het onderste veel lichtere gedeelte van de Unioklei. Dit profiel is volledig geaëreerd tot $\pm 50 \mathrm{~cm}$ en geheel ongeaëreerd beneden $70 \mathrm{~cm}$.

Omstreeks 1950 was ook reeds gebleken, dat de kwelderklei beter doorwortelbaar was dan de niet begroeide zeeklei. Er is sindsdien weinig verandering in de rijping gekomen.

3c. Het profiel op P 82 was omstreeks 1946 gerijpt tot $\pm 50 \mathrm{~cm}$ diepte. De huidige toestand is echter niet meer vergelijkbaar, daar deze kavel in 1947 en 1949 een ondergrondbewerking onderging tot $50 \mathrm{~cm}$ diepte. Hierbij werd getracht de lichtere sloef, die hier van $30-50 \mathrm{~cm}$ diepte voorkomt, los te maken. De eronder liggende zware humeuze sloef (was de gedachte) zou dan uit zichzelf wel goed worden. De aëratie is gevorderd tot $65 \mathrm{~cm}$, tot welke diepte de beworteling vrij dicht is.

3d. Het licht-op-zware-profiel met kwel op T 113 is tot $80 \mathrm{~cm}$ geheel en van $80-100 \mathrm{~cm}$ gedeeltelijk geaëreerd. Dit maakt het waarschijnlijk, dat hier weinig of slechts geringe kwel aanwezig was. Toch is de doorworteling van de zware zavel en klei $\mathrm{A}$ in de diepte geringer dan in vergelijkbare profielen zonder $\mathrm{kwel}$.

\section{Het profieltype licht op licht (zavel)}

De profielen van deze groep liggen alle in het westelijke gedeelte van de polder. Hun gemeenschappelijke kenmerk is de lichte-zavelbouwvoor, rustende op een min of meer dikke laag Espelzand. Onder het Espelzand bevindt zich een laag lichtere zavel (Zus), waaronder sloeflagen van wisselend karakter.

In het westen tegen de dijk is de oorspronkelijke Espelzand-bovengrond overdekt met een sliblaag. Door vermenging van deze sliblaag met het Espelzand ontstond een licht-zavelige bouwvoor. $\mathrm{Bij}$ afwezigheid van de sliblaag kan ook dẻ bouwvoor uit Espelzand bestaan.

De variaties in de profielen ontstaan door de zwaarte van de bouwvoor, de dikte van de Espelzandlaag, de zwaarte en dikte van de Zuslaag en de daaronder liggende sloef en het voorkomen van kwel.

Van de oorspronkelijke toestand van deze profielen is zeer weinig overgebleven, daar alle door een ondergrondbewerking werden losgemaakt.

In de oorspronkelijke toestand was het Espelzand matig of niet doorworteld, terwijl de eronder liggende lichte-zavellagen ongeaëreerd waren. Als gevolg van een betere ontwatering (drainage) vorderde de rijping wel, maar zeer langzaam, terwijl de doorworteling niet beter werd. Na een ondergrondbewerking gingen bẹide snel vooruit. 
TABEL 12. Wortelverdelingen (\%) in het profiel licht op licht (zavel) en de totale hoeveelheden wortels (in $\mathrm{mg}$ droge stof) in blokken van $10 \times 23 \times 50$ $\mathrm{cm}^{3}$.

\begin{tabular}{|c|c|c|c|c|c|c|}
\hline Type & $4 a$ & $4 a^{\prime}$ & $4 a^{\prime \prime}$ & $4 a^{\prime \prime \prime}$ & $4 a^{\prime \prime \prime \prime}$ & $4 a^{\prime \prime \prime \prime}$ \\
\hline Kavel & B 42 & B 53 & C 60 & D 30 & C: 121 & C 131 \\
\hline Datum & 23-8-’55 & $3-8-' 56$ & 24-8-'55 & 19-8-'55 & $15-8-' 55$ & 15-8-'55 \\
\hline Gewas & $\begin{array}{l}\text { Zomer- } \\
\text { tarwe }\end{array}$ & Haver & \multicolumn{4}{|c|}{ Wintertarwe } \\
\hline $\begin{array}{l}20-30 \mathrm{~cm} \\
30-40 \quad " \\
70-50 \quad, \\
50-60 \quad " \\
60-70 \quad "\end{array}$ & $\begin{array}{r}50 \\
27 \\
11 \\
9 \\
3\end{array}$ & $\begin{array}{l}25 \\
18 \\
25 \\
21 \\
11\end{array}$ & $\begin{array}{r}27 \\
25 \\
30 \\
13 \\
6\end{array}$ & $\begin{array}{r}39 \\
29 \\
12 \\
12 \\
9\end{array}$ & $\begin{array}{r}44 \\
24 \\
10 \\
18 \\
5\end{array}$ & $\begin{array}{r}32 \\
43 \\
12 \\
7 \\
6\end{array}$ \\
\hline $20-70 \mathrm{~cm}$ & $570 \mathrm{mg}$ & $1074 \mathrm{mg}$ & $320 \mathrm{mg}$ & $466 \mathrm{mg}$ & $558 \mathrm{mg}$ & $252 \mathrm{mg}$ \\
\hline
\end{tabular}

4a. Het profiel op B 42 bestaat to $40 \mathrm{~cm}$ diepte uit Espelzand, daaronder tot $60 \mathrm{~cm}$ uit een lichte zavel, rustend op een zeer zandige sloef. De lichte zavel behoort tot een sloefafzetting. Ondanks een ondergrondbewerking in 1953 tot $\pm 70 \mathrm{~cm}$ diepte is het verschil in doorworteling beneden $50 \mathrm{~cm}$ diepte zeer duidelijk. De aëratie was gevorderd tot $65 \mathrm{~cm}$.

$4 a^{\prime}$. Op B 53 bestaat de bouwvoor uit een lichte zavel met een dunne laag Espelzand eronder, Dieper bevindt zich een vrij dikke lichtezavellaag, waarvan het bovenste gedeelte behoort tot de Zus, het onderste gedeelte tot de sloef. Onder in het profiel is de sloef sterk zandig. Het profiel is in 1953 losgemaakt tot $\pm 70 \mathrm{~cm}$. De aëratie reikt tot $80 \mathrm{~cm}$. De grote wortelhoeveelheid moet worden toegeschreven aan de haver.

$4 a^{\prime \prime}$. Op C 60 is de Espelzandlaag onder de lichte-zavelbouwvoor vrij dik. Verder is het profiel gelijk aan het vorige. De zandige sloet begint echter reeds op $50 \mathrm{~cm}$ diepte, hetgeen aan de bewortelingsdichtheid goed is te zien. Ook dit profiel heeft een ondergrondbewerking ondergaan in 1954, met als gevolg een over de gehele diepte goede beworteling.

De aëratie reikte tot ongeveer $55 \mathrm{~cm}$, hetgeen eensdeels veroorzaakt kan zijn door een geringe kwel, anderdeels door de zandige sloế.

$4 \mathrm{a}^{\prime \prime \prime}$. Op D 30 (vgl. fig. $60, \mathrm{D} 21$ ) is de bouwvoor zwaarder, evenals de Zus en de sloef in de ondergrond. Alle grondsoorten behoren 
tot zwaartegroep 5. Het profiel is in 1953 losgemaakt. De doorworteling is goed en reageert niet op de Espelzandlaag tussen de lichte-zavellagen.

$4 a^{\prime \prime \prime}$. Op C 121 en C 131 is de bouwvoor iets zwaarder dan op D 30. Tussen bouwvoor en Zus bestaat het profiel uit een lichte zavel in plaats van uit Espelzand. Het profiel op C 121 is in 1952 losgemaakt tot $70 \mathrm{~cm}$. Ofschoon de totale aëratie in beide profielen tot $\pm 65 \mathrm{~cm}$ is gevorderd en de gedeeltelijke aëratie tot $\pm 100 \mathrm{~cm}$, is de doorworteling van $\mathrm{C}$ 12l regelmatiger dan op $\mathrm{C} 131$.

\section{Het profieltype licht op licht, zand}

Tot deze groep behoren alle zandprofielen die over de gehele diepte uit eenzelfde zandsoort bestaan. Enige variatie wordt gevormd door het voorkomen van dikke schelplagen of kwel.

TABEL 13. Wortelverdelingen (\%) in het profiel licht op licht (zand) en de totale hoeveelheden wortels (in mg droge stof) in blokken van $10 \times 23 \times 50$ $\mathrm{cm}^{3}$.

\begin{tabular}{|c|c|c|c|c|c|c|}
\hline Type & $4 b$ & $4 c$ & $4 d$ & $4 e$ & $4 f$ & $4 g$ \\
\hline KaveI & F 38 & R 75 & P 64 & K 10 & A 14 & S 30 \\
\hline Datum & $10-8-56$ & 12-8-'56 & $26-8-55$ & $23-8-55$ & $10-8-56$ & $4-8-55$ \\
\hline Gewas & $\begin{array}{l}\text { Winter- } \\
\text { tarwe }\end{array}$ & $\begin{array}{c}\text { Zomer- } \\
\text { tarwe }\end{array}$ & Haver & $\begin{array}{l}\text { Haver } \\
(\mathrm{K})\end{array}$ & Haver & $\begin{array}{l}\text { Winter- } \\
\text { rogge }\end{array}$ \\
\hline $\begin{array}{l}20-30 \mathrm{~cm} \\
30-40 \quad " \\
40-50 \quad " \\
50-60 ", \\
60-70 "\end{array}$ & $\begin{array}{r}37 \\
15 \\
25 \\
14 \\
9\end{array}$ & $\begin{array}{r}55 \\
31 \\
10 \\
3 \\
1\end{array}$ & $\begin{array}{r}54 \\
29 \\
14 \\
3 \\
0\end{array}$ & $\begin{array}{r}75 \\
15 \\
9 \\
2 \\
0\end{array}$ & $\begin{array}{r}49 \\
23 \\
16 \\
9 \\
3\end{array}$ & $\begin{array}{l}? \\
? \\
? \\
0 \\
0\end{array}$ \\
\hline $20-70 \mathrm{~cm}$ & $164 \mathrm{mg}$ & $883 \mathrm{mg}$ & $614 \mathrm{mg}$ & $401 \mathrm{mg}$ & $729 \mathrm{mg}$ & $?$ \\
\hline
\end{tabular}

4b. Profiel F 38 bestaat uit een zavelbouwvoor (stortgrond) op veen op pleistoceen zand. Het veen begint ongeveer op $20 \mathrm{~cm}$, de overgang van het veen naar het zand op $45 \mathrm{~cm}$. De doorworteling is regelmatig, maar dun.

4c. Het Blokzijlzandprofiel van $R 75$ vertoont de sterk, maar regelmatig afnemende worteldichtheid met toenemende diepte.

4d. Hetzelfde geldt voor het Ramspolzandprofiel van P 64 (fig. 47), waar echter de beworteling onderin belemmerd is door de infiltratie, die hier een grondwaterstand gaf van $-65 \mathrm{~cm}$. 
4e. Het Blokzijlzandprofiel van $\mathrm{K} 10$ heeft beneden de bouwvoor een met toenemende diepte stijgende hoeveelheid schelpen. Op $70 . \mathrm{cm}$ diepte gaat dit over in een schelpenbank. De aëratie eindigde op $100 \mathrm{~cm}$, hetgeen voor dit profiel vrij diep is. De bewortelingsverdeling neemt bij toenemende diepte zeer snel af, waarschijnlijk het meest onder invloed van de schelpen en verder door de bewortelingseigenaardigheid van de daar verbouwde korte haver (zie tabel 8).

4f. Op A 14 (fig. 48) is het Espelzandprofiel in 1954 tot $\pm 70 \mathrm{~cm}$ diepte losgemaakt. De aëratiediepte bedraagt $60 \mathrm{~cm}$. De wortelverdeling neemt in dit profiel vrij regelmatig af. Van de verschillende zandprofielen komt de wortelverdeling in dit Espelzandprofiel het dichtst bij die van een zavelprofiel.

4g. Het Urkzandprofiel van S 30 had een grondwaterstand van - 50 $\mathrm{cm}$, hetgeen tevens de grens van de beworteling was. Wegens de aanwezigheid van een grote hoeveelheid zoderesten was het niet mogelijk de hoeveelheid wortels te bepalen.

\section{Het profieltype waarin veen of detritus voorkomt}

De variatie in de profielen wordt voornamelijk veroorzaakt door de diepte waarop het veen begint, en de aanwezigheid van kwel of infiltratie. Ook van enkele gediepploegde veenprofielen wordt de beworteling aangegeven.

De aard van deze profielen brengt mee, dat voorzover de beworteling in het veen of detritus aanwezig is, de opgegeven hoeveelheden verre

TABEL 14. Wortelverdelingen (\%) in het profieltype zavel op veen en de totale hoeveelheden wortels (in $\mathrm{mg}$ droge stof) in blokken van $10 \times 23 \times 50 \mathrm{~cm}^{3}$.

\begin{tabular}{|c|c|c|c|c|c|c|c|c|c|}
\hline Type & $5 a$ & $5 a^{1}$ & $5 b$ & $5 b^{1}$ & $5 c$ & $5 c^{1}$ & $5 d$ & $5 e$ & $5 e^{1}$ \\
\hline Kavel & A 69 & A 76 & G 63 & F 51 & В 102 & C 93 & A 8 & K 40 & E 10 \\
\hline Datum & $25-8-55$ & $25-8-55$ & $10-8-56$ & $3-8-56$ & $10-8-56$ & $3-8-56$ & $10-8-56$ & $25-8-55$ & $26-8-55$ \\
\hline Gewas & $\begin{array}{c}\text { Zomer- } \\
\text { tarwe }\end{array}$ & $\begin{array}{c}\text { Winter- } \\
\text { tarwe }\end{array}$ & $\begin{array}{l}\text { Winter- } \\
\text { tarwe }\end{array}$ & $\begin{array}{l}\text { Winter- } \\
\text { tarwe }\end{array}$ & Haver & $\begin{array}{l}\text { Winter- } \\
\text { tarwe }\end{array}$ & Haver & $\begin{array}{c}\text { Winter- } \\
\text { tarwe }\end{array}$ & $\begin{array}{c}\text { Zomer- } \\
\text { tarwe }\end{array}$ \\
\hline $20-30 \mathrm{~cm}$ & 31 & 39 & 21 & 25 & 26 & 33 & 92 & 15 & 31 \\
\hline $30-40$ & 31 & 31 & 22 & 32 & 16 & 29 & 8 & 20 & 28 \\
\hline $40-50$ & 23 & 28 & 24 & 13 & 19 & 15 & 0 & 22 & 30 \\
\hline $50-60 "$ & 11 & 1 & 25 & 22 & 20 & 18 & 0 & 27 & 9 \\
\hline $60-70 "$ & 3 & 1 & 8 & 8 & 18 & 6 & 0 & 16 & 1 \\
\hline $20-70$ & $318 \mathrm{mg}$ & $114 \mathrm{mg}$ & $454 \mathrm{mg}$ & $524 \mathrm{mg}$ & $575 \mathrm{mg}$ & $692 \mathrm{mg}$ & $282 \mathrm{mg}$ & $254 \mathrm{mg}$ & $310 \mathrm{mg}$ \\
\hline
\end{tabular}


van betrouwbaar zijn. De scheiding van de wortels uit een compacte veenmassa gelukte slechts zelden volledig, zodat de wortelhoeveelheden werden geschat.

5a. Het profiel op A 69 bestaat uit een bouwvoor van lichte zavel op zeggeveen. Het veen is tot aan de aëratiegrens $(55 \mathrm{~cm}$ diepte) goed doorworteld. De hoeveelheid wortels is geschat.

$5 \mathrm{a}^{\prime}$. Het profiel op A 76 (fig. 49 ) heeft een iets zwaardere bouwvoor, rustend op detritus. Tot ongeveer $25 \mathrm{~cm}$ diepte is de detritus droog, daaronder vochtig. $\mathrm{Op} \pm 45 \mathrm{~cm}$ diepte begint de zandondergrond, die door infiltratie nat is. De bewortelingsdichtheid in de detritus is gering.

5b. Op G 63 begint het veen op $60 \mathrm{~cm}$ diepte. De doorworteling van het bovenliggende zwaar-op-licht-profiel is normaal. In het veen neemt de beworteling sterker af dan in overeenkomstige profielen, waar op deze plaats zavel in het profiel voorkomt.

$5 b^{\prime}$. Op F 51 begint de detritus-ondergrond op $50 \mathrm{~cm}$. De doorworteling van deze detritus is vergelijkbaar met die van zavel, behalve in de onderste laag $(60-70 \mathrm{~cm})$.

5c. Op B 102 begint het veen pas op $80 \mathrm{~cm}$ diepte. Van $50-70 \mathrm{~cm}$ is de grond sterk gelaagd met humeuze banden. De doorworteling van dit profiel is goed.

$5 \mathrm{c}^{\prime}$. Op C 93 begint de detritus op ongeveer $50 \mathrm{~cm}$, van de zavelbouwvoor gescheiden door een zeer zandige sloeflaag. Daar deze sloeflaag geheel is losgemaakt, is ook hierin de beworteling goed.

5 d. Het profiel van A 8 (fig. 50) had het veen op grotere diepte dan werd verwacht en kwam daardoor het meest overeen met type $4 \mathrm{f}$, licht op licht, een bouwvoor van lichte zavel rustend op Espelzand. Ten gevolge van een grondwaterstand van $-40 \mathrm{~cm}$ is het profiel beneden die diepte niet geaëreerd. De doorworteling reageert hierop zeer sterk. Reeds in de laag van $30-40 \mathrm{~cm}$ is de doorworteling gering.

5e. Het veen-op-zandprofiel van $\mathrm{K} 40$ (fig. 51) is gediepploegd. De doorworteling van dit profiel is regelmatig, ondanks het voorkomen van grote brokken veen en detritus in het profiel.

$5 \mathrm{e}^{\prime}$. Het gediepploegde profiel van $\mathbf{E} 10$ bestaat uit grof gemengde, lichte humeuze zavel en humeuze zandige sloef. De wortelverdeling is wat on regelmatig door de van plek tot plek andere samenstelling. De doorworteling is goed, kan echter onder in het profiel wat minder goed zijn, indien daar een dikke laag Espelzand voorkomt die door het diepploegen naar beneden is verplaatst.

\section{Samenvatting}

In dit hoofdstuk werd de ontwikkeling van het wortelstelsel in verschillende grondsoorten beschreven, d.w.z. in grondsoorten die anders 
zijn dan de zavel van type la. De enkelvoudige waarnemingen aan de diverse profielen laten zien, dat de doorwortelbaarheid van de verschillende grondsoorten beter is dan op grond van de in hoofdstuk III beschreven eigenschappen kon worden verwacht. Hierbij moet worden bedacht, dat een nog steeds voortgaande rijping als gevolg van verbeterde ontwatering en voortdurende begroeiing de structuur van de ondergrond beter doet worden. Ook lagen die door hun granulaire samenstelling zeer moeilijk scheuren, vertonen op den duur toch ook nog enige scheurvorming. Het losmaken van de ondergrond, in die gevallen dat een natuurlijke scheurvorming niet werd verwacht. (zand en zandige sloef), heeft een groot antal profielen in een voor doorworteling gunstige toestand gebracht.

Van het type zwaar op zwaar zijn de homogene profielen het regelmatigst doorworteld. De invloed van de kwel valt in het onderzochte profiel erg mee (T 51, 1e).

Waar in deze groep zware sloef of oude zeeklei voorkomt, neemt de beworteling met toenemende diepte iets sterker af dan in het homogene profiel.

In het type zwaar op licht is de verdeling van de wortels ook betrekkelijk regelmatig. In de onderste laag neemt de beworteling sterker af, vaak door de aanwezigheid van zandige sloef.

Waar in het profiel de sloef een zandig karakter heeft of kwel of infiltratie voorkomt, wordt de beworteling op een geringere diepte al mindei.

Het type licht op zwaar heeft een regelmatige wortelverdeling, behalve bij aanwezigheid van oude zeeklei in de ondergrond. De groep komt dus goed overeen met zwaar op zwaar.

Het type licht op licht (zavel en sloef) is van oorsprong slecht doorwortelbaar. Ten gevolge van ondergrondbewerkingen is de beworteling in deze profielen regelmatig geworden.

Het type licht op licht (zand) is het minst goed doorwortelbaar. In het profielgedeelte van $20-70 \mathrm{~cm}$ bevindt zich het grootste deel der wortels tussen 20 en 30 à $40 \mathrm{~cm}$. Waar de wortelverdeling regelmatig is - als in $4 \mathrm{~b}$ (F 38) - is de hoeveelheid toch zo gering, dat niet van een goede doorworteling kan worden gesproken.

Het type met veen in het profiel is goed. Enige verschillen staan voornamelijk in verband met de geaëreerdheid van het veen onder invloed van de grondwaterstand. Gediepploegde veenprofielen worden goed doorworteld. 


\section{DE ONDERGRONDBEWERKINGSPROEFVELDEN}

\section{Inleiding}

De waarnemingen betreffende de invloed van bepaalde profieleigenschappen op de rijping van de grond en de wortelontwikkeling van de gewassen (hoofdstuk III en IV) doen duidelijk uitkomen, dat een onbeperkte bewortelingsdiepte van deze laatste niet altijd mogelijk is. Ofschoon de landbouwgewassen zeker in staat zijn een grotere diepte dan $100 \mathrm{~cm}$ beneden de bodemoppervlakte te bereiken, werd deze diepte ruimschoots voldoende geacht voor de benodigde voedsel- en vochtvoorziening. Een beperking van de wortelgroei, dus ook van het doorwortelbare bodemvolume, tot geringere diepten dan $70 \mathrm{~cm}$ beneden maaiveld moet evenwel onvoldoende worden geacht met betrekking tot de vochtvoorziening, indien aan deze tenminste niet op kunstmatige wijze wordt tegemoet gekomen.

Ofschoon de oorzaken van beperkte wortelgroei ten gevolge van een te dichte pakking, n.l. te grote mechanische weerstand of onvoldoende zuurstofvoorziening, niet geheel duidelijk zijn, is het aanvaardbaar dat door het losmaken van de dichte lagen een gunstige verandering zal optreden. De mechanische weerstand wordt geringer, omdat de grond "los" wordt gemaakt, en de zuurstofvoorziening kan beter worden, als gevolg van het optreden van grotere poriën en scheuren. De verhoudingen tussen de vaste, vloeibare en gasvormige bestanddelen in de bodem worden dan gewijzigd, zonder dat kan worden aangegeven welke verandering van de meeste betekenis is voor de wortelgroei.

Het losmaken van de ondergrond door middel van een mechanische ondergrondbewerking heeft tot doel:

1. de rijping te bevorderen;

2. dichte lagen losser te maken;

3. de ontwatering te verbeteren.

De verwezenlijking van deze doeleinden kan in alle drie de gevallen een diepere doorworteling mogelijk maken.

Ofschoon de doelstellingen in theorie dus duidelijk kunnen worden onderscheiden, blijkt in de praktijk dat zij vaak verschillende facetten van hetzelfde probleem zijn.

'Een onvoldoend rijpende grond ondervindt meestal ook moeilijkheden met de ontwatering. Hierin is door ondergrondbewerking alleen verbetering te brengen, indien de aard van het profiel (b.v. zandige sloef) 


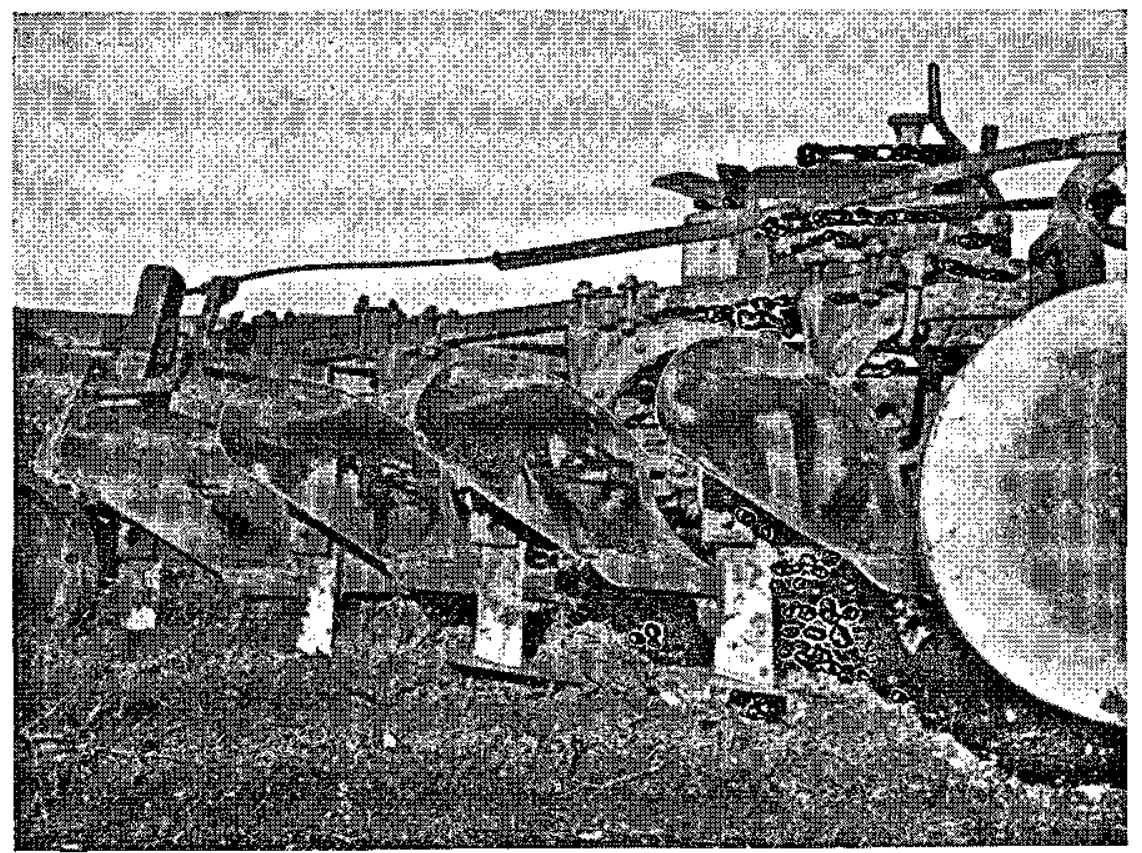

Fig. 11: Mc. Cormick ploeg met ondergronders. Mc. Cormick plough with subsoilers

een langzame rijping veroorzaakt. Een onvoldoende rijping welke het gevolg is van het niet beheersen van de grondwaterstand, zal meestal niet door een ondergrond-bewerking kunnen worden opgeheven.

Harde, moeilijk of niet doorwortelbare lagen belemmeren eveneens de ontwatering (B-horizonten). Door het losmaken (breken) van deze lagen kan zowel de beworteling als de ontwatering beter worden.

Een verbetering van de ontwatering als gevolg van het losmaken van harde lagen of een moldrainage-effect van enkele werktuigen kan een verbeterde rijping en beworteling tot gevolg hebben.

In dit hoofdstuk worden eerst de gebruikte werktuigen besproken en vervolgens de onderzoekingen naar de resultaten van het ondergrondbreken.

\section{De gebruikte werktuigen}

De in de Noordoostpolder voor het losmaken van de ondergrond gebruikte werktuigen worden door DE BOER in twee groepen ingedeeld:

1. De normale ploegen met mogelijkheid tot het breken van de ondergrond onder de ploegzool.

2. De ondergrondbrekers. 


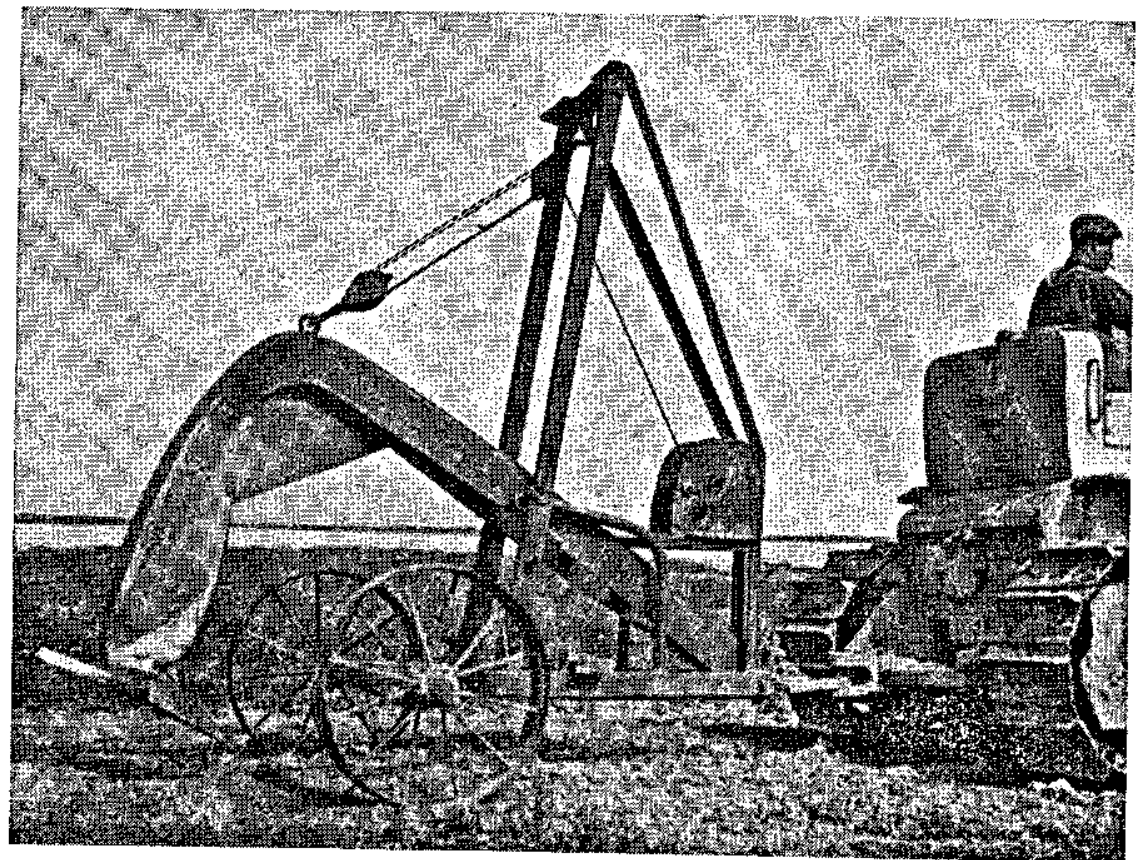

Fig. 12. Vernielploeg.

Heavy duty subsoiler.

De meest gebruikte ploegen van de eerste groep zijn de Mc. Cormick Little Genius no. 14 en de Rud Sack C.Z. 9 A 6, E.D. 25 en C 10 Z.V., alle vierscharige ploegen.

De Rud Sack ploegen worden door de fabriek uitgerust met ondergrondbrekers. De grootste werkdiepte bedraagt $16 \mathrm{~cm}$ onder de ploegzool, hetgeen te weinig is voor sommige doeleinden.

Door de werkplaats van de Directie van de Wieringermeer werden ondergrondbrekers geconstrueerd met een iets grotere werkdiepte, zodat een totale werkdiepte van $\pm 40 \mathrm{~cm}$ kon worden bereikt.

De ondergrondbreker werkt achter het rister, aan de vaste kant van de voor. Om te voorkomen dat voorwiel en stuurwiel van de ploeg door de losgemaakte voren zullen lopen, is achter het vierde rister geen ondergrondbreker geplaatst. Deze is naar voren geschoven en bevestigd tussen het voorste rister en het voorwiel.

De Mc. Cormick ploegen (fig. 11) zijn door de werkplaats van ondergrondbrekers voorzien, geplaatst achter en bevestigd aan de risters. Deze zware ploegen kunnen, indien bepaalde voorzieningen worden getroffen, ruim $20 \mathrm{~cm}$ diep ploegen en onder de ploegzool 30 à $35 \mathrm{~cm}$ breken. De totale werkdiepte bedraagt dan $55 \mathrm{~cm}$.

De normale vorm van ondergrondbrekers is de ganzevoet. De brekende werking dezer modellen is echter te gering, zowel ten aanzien 


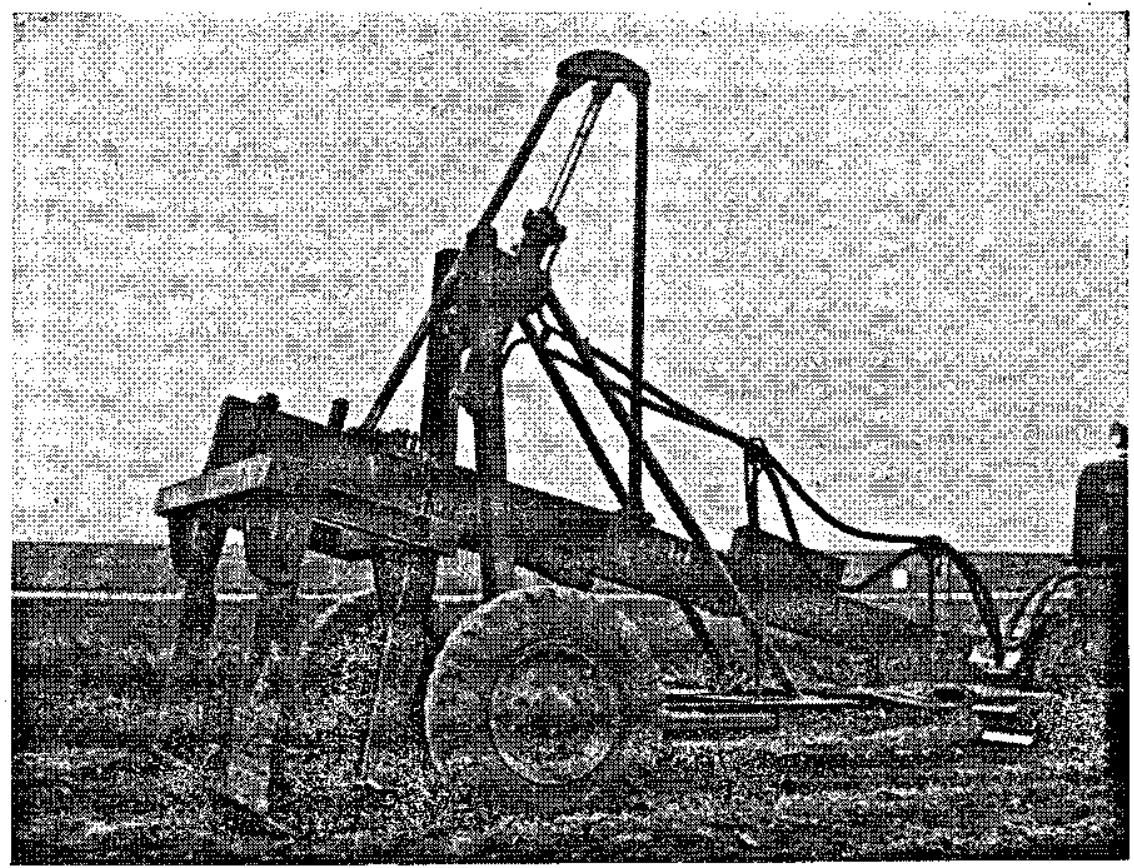

Fig. 13. Ondergrondbreker op greppelploegonderstel: Neptunus. Subsoiler for deep shattering of the soil.

van de mate van het opbreken als ten aanzien van de werkbreedte.

De Rud Sack en de Mc. Cormick ploegen zijn voorzien van ondergrondbrekers van ongeveer $35 \mathrm{~cm}$ breedte, loodrecht gesteld op de arm van de ondergronder, scheef op de voortbewegingsrichting van de ploeg en onder een kleine hoek met het horizontale vlak. De ondergrondbrekers geven de indruk van een tweede, laag geplaatste schaar, schuin naar achteren onder het rister. De werking van deze ondergrondbrekers is aan het opgolven van de ploegvoor goed te zien.

De bedoelde ondergrondbrekers zijn verstelbaar, zodat hun werkdiepte regelbaar is.

Tot de tweede groep behoren de vernielploeg en de ondergrondbreker-op-greppelploegonderstel.

De vernielploeg (fig. 12) bestaat uit een verticale, in doorsnede driehoekige balk, onderaan voorzien van een grote ganzevoet, het geheel gedragen door een greppelploegonderstel. Dit werktuig kan tot een diepte van 80 à $100 \mathrm{~cm}$ sleuven door de grond trekken, die de verticale waterbeweging goed bevorderen. De ganzevoet laat vaak een gang in de grond achter, die, indien hij dwars over de drains ligt, de afvoer van het water eveneens bevordert. In de sleuf wordt de ligging van de grondlagen sterk verstoord. In de regel is het niet te vermijden, dat de onder- 
grond naar boven komt. De vernielploeg wordt gebruikt om, op afstanden variërende van 2-8 m, sleuven dwars over de drains te trekken. Het doel is verbetering van de ontwatering.

Van deze vernielploeg is de ondergrondbreker-op-greppelploegonderstel afgeleid (fig. 13). Hij bestaat uit een raam waaraan drie verticale zware messen zijn opgehangen op een onderlinge afstand van $90 \mathrm{~cm}$. Onderaan deze messen zijn zware rechthoekige voeten bevestigd, welke ongeveer $40 \mathrm{~cm}$ breed en lang zijn. In werkstand maken deze voeten een kleine hoek met het horizontale vlak. De verticale messen verstoren de gelaagdheid niet en brengen geen ondergrond naar boven.

De voeten lichten de gehele bovenliggende grondkolom op, welke na het passeren van de voet omlaag valt en breekt. Als onderstel werd gebruik gemaakt van de trekbalk van een greppelploeg. Aan deze trekbalk werd een raam bevestigd, waaraan de ondergrondbrekers draaiend werden opgehangen met boven het scharnierpunt een bout als zekering. Bij het tegenkomen van obstakels breekt de bout en slaat de ondergrondbreker achterover zonder te woren beschadigd. Deze ondergrondbreker wordt gebruikt yoor werkdiepten van $50-70 \mathrm{~cm}$.

Het gebruik van ploegen-met-ondergrondbrekers en van ondergrondbrekers-op-greppelploeg-onderstel heeft voor-en nadelen.

De ploegen met ondergrondbrekers maken de gehele ondergrond tot een bepaalde diepte los. De bewerking geschiedt in één gang, zodat niet meer over de losgemaakte grond wordt gereden. Daar de grond tevens wordt geploegd, zal deze bewerking in het algemeen niet veel eerder gebeuren dan op het tijdstip dat gewoonlijk gekozen wordt voor het ploegen, n.l. de herfst. De grond is dan vaak niet zo droog als gewenst is voor goed breken. De ploegen met ondergrondbrekers vragen meer dan een verdubbelde trekkracht. De hiervoor benodigde trekkers kunnen het land stuk rijden. Worden deze ploegen onder zeer slechte omstandigheden gebruikt (hetgeen niet mag, maar wel eens voorkomt), dan is het ondergrondbreken alleen al nodig om de diepe sporen van de trekkers en ploegwielen los te maken.

De ondergrondbreker-op-greppelploegonderstel (meestal „drietand" of "Neptunus" genoemd) moet bij voorkeur dadelijk nadat de oogst van het land is, worden gebruikt. Behalve bij suikerbieten en late aardappelen, is de grond dan meestal droog. Stoppelklavers, mits niet bedoeld voor de drogerij, verdragen de werking voldoende goed. Het op wintervoorploegen kan door de ondergrondbewerking, indien deze goed geslaagd is, onder drogere omstandigheden geschieden dan indien de ondergrondbewerking achterwege was gebleven. De ligging van de grond is in de regel echter ongelijkmatiger. De ploeg krijgt bovendien neiging om weg te zakken, daar de losgemaakte grond niet voldoende steun aan de wielen en zolen geeft.

De voor de Neptunus benodigde trekkracht bedraagt $12000 \mathrm{~kg}$ bij een werkdiepte van $70 \mathrm{~cm}$ en en onderlinge afstand van de drie poten van $90 \mathrm{~cm}$. 

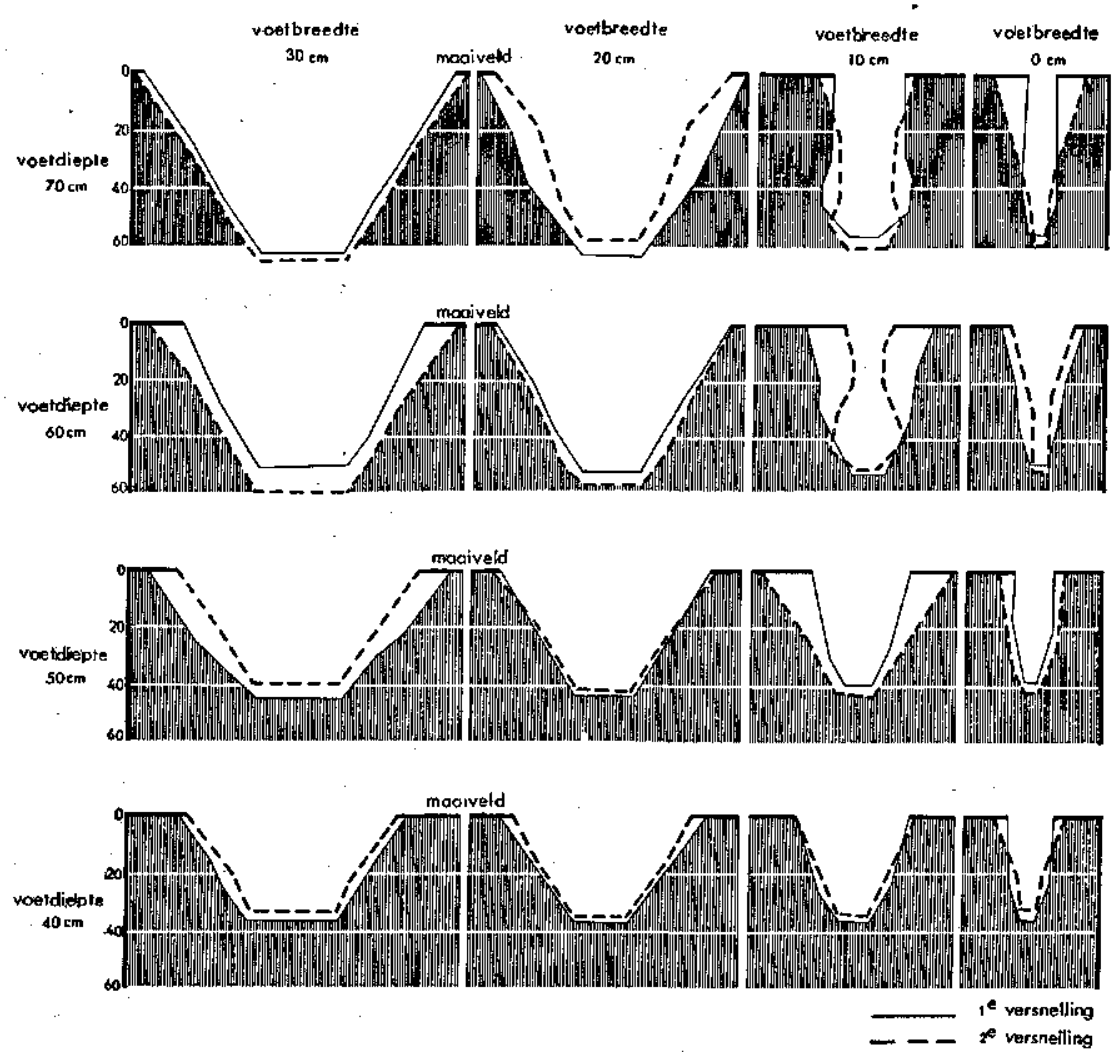

Fig. 14. Dwarsdoorsneden van de losgemaakte grond door één poot van de Neptunus, volgens tabel 15 .

Crossections of the loosened soil, after subsoiling, according to table 15, with different widths and working depths of the chisel.

Door middel van trekkrachtproeven werd onderzocht in hoeverre de benodigde trekkracht afhangt van de diepte waarop de voet door de grond wordt getrokken, en van de afmetingen van de voet. Hierbij werd tevens nagegaan, in welke mate het profiel werd losgemaakt:

De proef werd genomen op kavel A 19 op 21 mei 1953. Het profiel was als volgt:

$0-47 \mathrm{~cm}$ zand (2d)

$47-80, \quad$ zandige sloef (2e).

Tot $25 \mathrm{~cm}$ diepte kwamen veel riet-rhizomen voor. De.grond was intensief bewerkt tot $10 \mathrm{~cm}$ diepte. De aëratiediepte bedroeg plm. $45 \mathrm{~cm}$, de grondwaterstand $90 \mathrm{~cm}$ beneden maaiveld.

Voor de proef werden 2 tanden van de Neptunus verwijderd. De overblijvende tand was $100 \mathrm{~cm}$ lang, $20 \mathrm{~cm}$ breed en $5 \mathrm{~cm}$ dik. De voet was $30 \mathrm{~cm}$ lang en breed en onder een kleine hoek aan het mes gelast. 
Voorzijde van mes en voet waren scherp uitgesmeed, de oppervlakte door het gebruik glad. Het werktuig werd getrokken door een Allis Chalmers H D 9 rupstrekker met snelheden van 2.22 en $3.36 \mathrm{~km}$ per uur (berekend). Gewerkt werd op diepten van $70,60,50$ en $40 \mathrm{~cm}$ over afstanden van $50 \mathrm{~m}$.

Met een snijbrander werd de breedte van de yoet gebracht van $30 \mathrm{~cm}$ op $20 \mathrm{~cm}, 10 \mathrm{~cm}$ en geheel zonder voet.

De benodigde trekkracht werd om de $10 \mathrm{~m}$ afgelezen van een tussen trekker en Neptunus aangebrachte dynamometer. De gemiddelde afgelezen waarde werd verminderd met de trekkracht benodigd voor het trekken van de uit het werk gezette Neptunus.

Het losgemaakte gedeelte van het profiel werd bij elk onderdeel eenmaal opgemeten in een dwars op de rijrichting gegraven kuil.

TABEL 15. Benodigde trekkracht en oppervlakte losgemaakte doorsnede bij de beproeving van de Neptunus met één mes met voet.

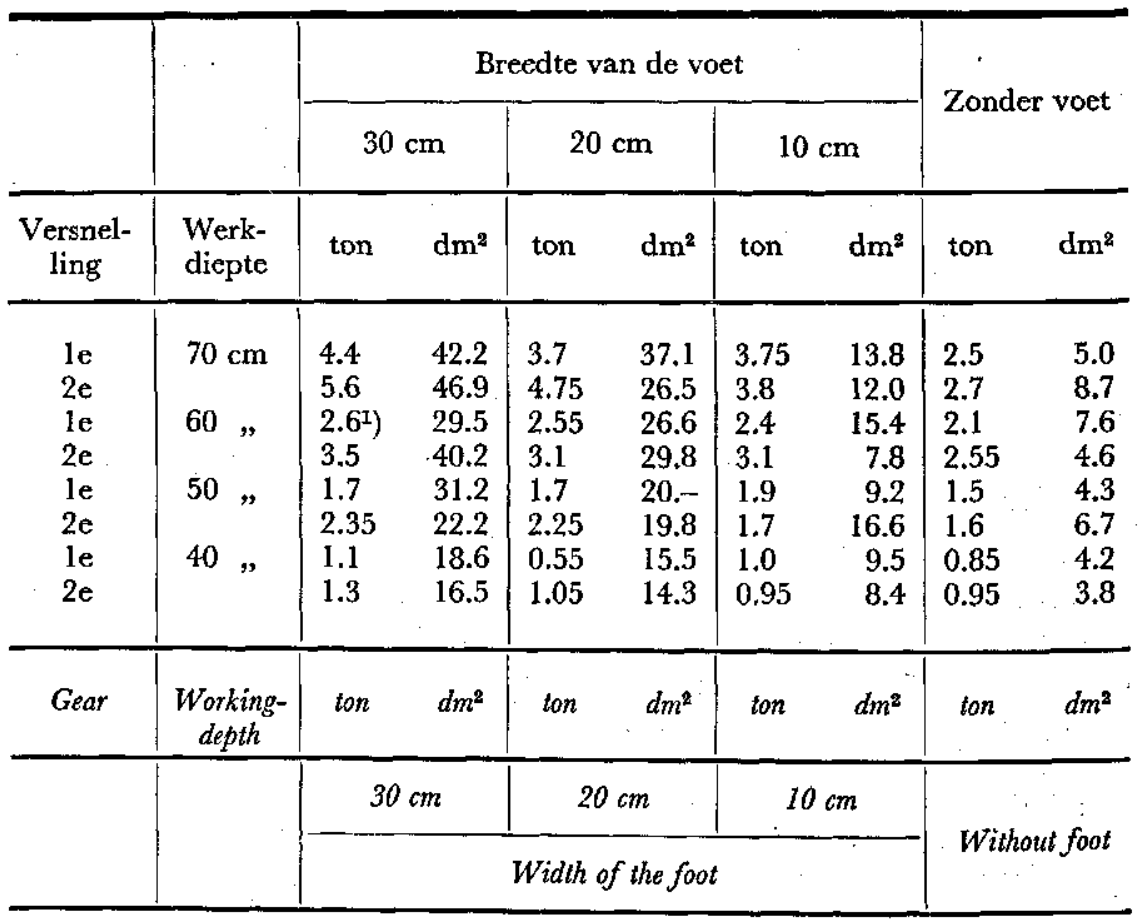

1) geschat estimated

TABLE 15. Drawbar pull and area of the loosened cross-section by the trying of a subsoiler. with one foot (see fig. 13). 

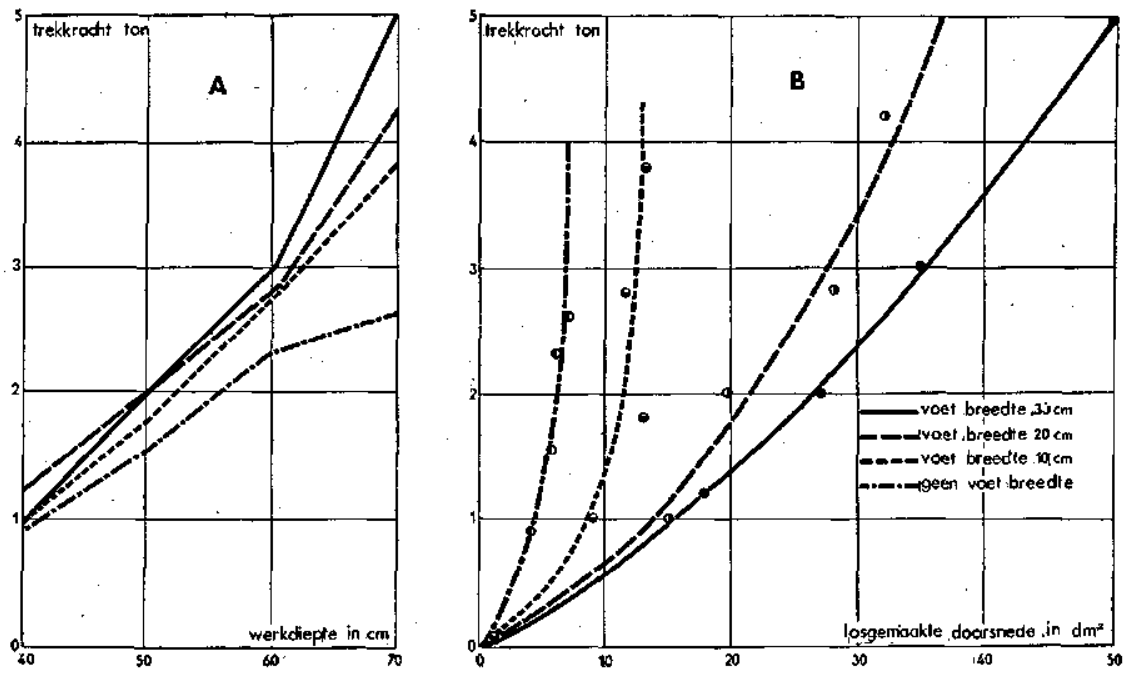

Fig. I5a. Verband tussen de benodigde trekkracht (in tonnen) en de werkdiepte voor één poot van de Neptunus.

Relation between drawbar pull (tons) and working depth for one leg of the subsoiler of fig. 13, with different widths and working depths of the chisel.

Fig. 15b. Verband tussen de benodigde trekkracht (in tonnen) en de losgemaakte doorsnede voor één poot van de Neptunus.

Relation between drawbar pull (tons) and the loosened crossection for one leg of the subsoiler of fig. 13, with different widths and working depths of the chisel.

Figuur 14 geeft de dwarsdoorsnede weer van het losgemaakte gedeelte van het profiel. De invloed van de breedte van de voet op de losgemaakte doorsnede blijkt hieruit zeer duidelijk. De werkdiepte beïnvloedt uiteraard eveneens de losgemaakte doorsnede. De werkingsdiepte is bij deze proef steeds geringer geweest dan de bedoeling was. Het is niet goed mogelijk bij de gebruikte proefopzet, waarbij in één gang op verschillende diepten werd gewerkt bij twee snelheden, de diepten goed te regelen. De diepte wordt n.l. sterk beïnvloed door de mate van insporen van de wielen van het greppelonderstel. De bij de Neptunus behorende afstelblokken van verschillende hoogte waren bedoeld voor de drietandige Neptunus. Daar de insporing met één tand, zoals tijdens deze proef het geval was, minder diep is dan met drie tanden, is dat waarschijnlijk de oorzaak van het te ondiep lopen van de voet.

De benodigde trekkracht en de losgemaakte doorsnede onder de verschillende omstandigheden zijn vermeld in tabel 15.

Uit deze gegevens blijkt, dat bij de diepste bewerking ongeveer de helft van de trekkracht nodig is om het mes door de grond te trekken. 
Bij geringere diepten is voor het mes een nog groter deeI van de trekkracht nodig.

In de figuren $15 a$ en $15 b$, waarin de samenhang tussen benodigde trekkracht, bewerkingsdiepte, voetbreedte en losgemaakte doorsnede is weergegeven, komt eveneens duidelijk tot uiting dat een smalle voet ongunstig is en een brede het meeste resultaat geeft. Ter vereenvoudiging zijn de gegevens gemiddeld over de twee snelheden.

\section{Proefvelden}

Aan de voorwaarde, dat alle andere omstandigheden dan de te onderzoeken objecten gelijk moeten zijn, kunnen proefvelden op het gebied van grondbewerking in het algemeen niet voldoen. $\mathrm{Zij}$ zullen in het algemeen evenmin een voldoend aantal herhalingen bevatten. Aan het verlangen naar een verdeling van de objecten volgens toeval kan dientengevolge evenmin worden tegemoet gekomen.

Indien de ontwatering door een ondergrondbewerking wordt beïnvloed, dienen de objecten bovendien een zodanige omvang te hebben dat bij de waarnemingen voldoende zekerheid bestaat dat neveninvloeden zijn uitgesloten. Een bezwaar is, dat de reikwijdte van verschillende behandelingen bij de aanleg van de proefvelden in de regel nog niet bekend. is.

De benodigde oppervlakte voor de grondbewerkingsproefvelden is door dit alles nogal groot. Dit heeft tot gevolg, dat het uitvoeren van de verschillende bewerkingen in het gunstigste geval enige dagen duurt, in het ongunstigste geval enige weken en soms meer dan een maand. Gezien de invloed van het weer op de structuur van de grond, is dit ongewenst, doch onvermijdelijk. De interpretatie van bepaalde verschijnselen wordt onder dergelijke omstandigheden echter zeer twijfelachtig. Door een uitgebreidere opzet kan daaraan wel worden tegemoetgekomen, doch met alle bezwaren verbonden aan zeer uitgebreide proefvelden. Het volgende voorbeeld moge dit toelichten.

Voor een onderzoek naar de invloed van een ondergrondbewerking op de opbrengst van gewassen worden de volgende objecten gekozen:

1. een normale grondbewerking $(20 \mathrm{~cm}$ diep ploegen);

2. een ondergrondbewerking, gevolgd door de normale grondbewerking;

3. een ondergrondbewerking waarbij tegelijkertijd wordt geploegd.

De bewerking onder 2 kan worden uitgevoerd als stoppelbewerking onder droge omstandigheden. In die tijd van het jaar is daar voldoende speling voor.

De normale grondbewerking behoeft geen probleem op te leveren, tenzij het ploegen door een kortere of langere regenperiode wordt onderbroken. Indien door de ondergrondbewerking de ontwateringstoestand wordt verbeterd, is men iets minder afhankelijk van het weer.

De derde bewerking is het meest afhankelijk van het weer.

De benodigde grotere trekkracht en de wens om de ondergrondbewerking in een droge tijd uit te voeren, geven weinig speelruimte ten aanzien van de neerslag. 
Indien door ongunstige weersomstandigheden de uitvoering van deze proef enige weken of langer duurt, kan geprobeerd worden door uitbreiding van het eerste object de invloed van het weer en de tijd van het ploegen te bepalen. Het is dan nodig telkens wanneer een bouwvoorbewerking op een van de objecten plaatsvindt, een bepaalde oppervlakte een normale grondbewerking te geven.

De moeilijkheden zouden uiteraard het eenvoudigst kunnen worden voorkomen door zoveel werktuigen in te zetten dat het proefveld in enkele dagen klaarkomt. Dit is in de regel onmogelijk, zelfs in de Noordoostpolder.

De invloed van het Iosmaken van de ondergrond werd nagegaan op plaatsen waar

1. sloef in de ondergrond voorkomt: kavels $Q 65$ en $O 98$;

2. zand in de ondergrond voorkomt: kavel $\mathrm{M} 128$;

3 . het gehele profiel uit zand of lichte zavel bestaat met zandige sloef in de ondergrond: kavels B 68, C 62 en D 24.

a. Het proefveld op kavel $Q 65$.

Profiel: $\begin{array}{rlll}0--20 & \mathrm{~cm} & \text { Zu I } & 6 \\ 20-30 & \Rightarrow & \text { Zu II } & 8 \\ 30-34 & \Rightarrow & \text { Zu III } & 2 \text { f } \\ 34-40 & \Rightarrow & \text { Zus } & 4 \\ 40-60 & \text { Sl. Ia } & 4 \\ 60-90 & \Rightarrow & \text { Sl. Ib } & 4 \mathrm{~h} .\end{array}$

Dit proefveld bestaat dus uit een bovengrond van zware zavel, gescheiden van een licht zavelige sloef-ondergrond door een dikke laag zeer fijn zand.

In december 1948 werd een aantal akkers bewerkt met de vernielploeg in de richting van de akkers. Enige akkers werden niet bewerkt, een aantal met een onderlinge afstand van de woelsleuven van $1 \mathrm{~m}$ en een aantal met een onderlinge afstand van $2 \mathrm{~m}$. Dwars hieroverheen werd in het voorjaar van 1949 de grond geploegd. Een gedeelte werd op $15 \mathrm{~cm}$ diepte geploegd, een ander gedeelte op $25 \mathrm{~cm}$ diepte; verder werd geploegd met de Mc. Cormick ploeg met ondergronders tot op een totale diepte van $50 \mathrm{~cm}$, waarvan $30 \mathrm{~cm}$ werd geploegd.

Daar de objecten van het ploegen kruiselings over de gewoelde stroken lagen en elke behandeling in tweevoud geschiedde, kwam uiteindelijk elke combinatie van woelen en ploegen in viervoud op het proefveld voor.

Een gedeelte van het proefveld had echter in het voorafgaande jaar een zware gift stalmest ontvangen voor een proef met verschillende hoeveelheden stikstof, met als proefgewas in 1948 zomertarwe met hopperups als ondervrucht. Op het gedeelte met stalmest werd geen hopperups gezaaid. Het aantal bruikbare herhalingen werd daardoor geringer, n.l. de objecten: niet woelen en om de $2 \mathrm{~m}$ woelen in tweevoud. 
Het object $15 \mathrm{~cm}$ ploegen werd tenslotte ook in enkelvoud geoogst. Gewas in 1949 Klein Wanzleben E suikerbieten.

Gedurende het gehele groeiseizoen werden geen verschillen tussen de objecten waargenomen.

De bieten werden gerooid, gekopt en gewogen op 11 oktober. De schieters werden hierbij apart gehouden.

$\mathrm{Na}$ het wegen werden de bieten verdeeld in normale bieten, bieten met normale vorm maar zonder pen, en sterk vertakte bieten (zie fig. 28).

TABEL 16. Gemiddelde opbrengsten (kg/are) van de suikerbieten op het ondergrondbewerkingsproefveld op kavel Q 65 in 1949.

\begin{tabular}{l|cc|cc|cc|l}
\hline \multicolumn{1}{c|}{ Grondbewerking } & $15 \mathrm{~cm}$ & $25 \mathrm{~cm}$ & $30+20 \mathrm{~cm}$ & \\
\hline & Biet & Kop & Biet & Kop & Biet & Kop & \\
Niet gewoeld & 464 & 440 & 438 & 404 & 491 & 387 & Na zomertarwe \\
Op 2 m gewoeld & 478 & 428 & 442 & 417 & 424 & 382 & met hopperups \\
Op 1 m gewoeld & 467 & 433 & 466 & 422 & 438 & 415 & $\mid$ \\
Niet gewoeld & 473 & 328 & 158 & 284 & 459 & 287 & Na zomertarwe \\
Op 2 m gewoeld & 449 & 265 & 412 & 259 & 426 & 270 & zonder hopperups \\
\hline
\end{tabular}

TABEL 17. De gemiddelde hoeveelheden $(\%)$ van de verschillende bietvormen geoogst op het ondergrondbewerkingsproefveld op kavel Q 65 in 1949.

\begin{tabular}{|c|c|c|c|c|c|c|c|c|c|c|}
\hline Grondbewerking & & $15 \mathrm{cn}$ & & & $25 \mathrm{~cm}$ & & $30-$ & +20 & $\mathrm{~cm}$ & \\
\hline $\begin{array}{l}\text { Niet gewoeld } \\
\text { Op } 2 \mathrm{~m} \text { gewoeld } \\
\text { Op } 1 \mathrm{~m} \text { gewoeld }\end{array}$ & $\begin{array}{c}\mathrm{n}^{1} \\
66 \\
73 \\
78\end{array}$ & $\begin{array}{r}\mathrm{k}^{\mathbf{1}} \\
15 \\
9 \\
10\end{array}$ & $\begin{array}{l}\left.t^{1}\right) \\
19 \\
18 \\
12\end{array}$ & $\begin{array}{l}\mathbf{n} \\
73 \\
82 \\
82\end{array}$ & $\begin{array}{r}\mathrm{k} \\
15 \\
7 \\
9\end{array}$ & $\begin{array}{r}\mathrm{t} \\
12 \\
11 \\
9\end{array}$ & $\begin{array}{c}\mathbf{n} \\
72 \\
78 \\
84\end{array}$ & $\begin{array}{r}\mathbf{k} \\
15 \\
10 \\
8\end{array}$ & $\begin{array}{r}\mathrm{t} \\
13 \\
12 \\
8\end{array}$ & $\begin{array}{l}\text { Na zomertarwe } \\
\text { met hopperups }\end{array}$ \\
\hline $\begin{array}{l}\text { Niet gewoeld } \\
\text { Op } 2 \text { m gewoeld }\end{array}$ & $\begin{array}{l}62 \\
68\end{array}$ & $\begin{array}{l}21 \\
20\end{array}$ & $\begin{array}{l}17 \\
12\end{array}$ & $\begin{array}{l}67 \\
74\end{array}$ & $\begin{array}{l}21 \\
15\end{array}$ & $\begin{array}{l}12 \\
11\end{array}$ & $\begin{array}{l}70 \\
75\end{array}$ & $\begin{array}{l}18 \\
14\end{array}$ & $\begin{array}{l}12 \\
11\end{array}$ & $\left\{\begin{array}{l}\text { Na zomertarwe } \\
\text { zonder hopperups }\end{array}\right.$ \\
\hline
\end{tabular}

1) $\mathrm{n}$ normale biet

k = korte biet, zonder staart

$\mathrm{t}=$ sterk vertakte biet

\section{Samenvatting}

De invloed van het woelen is niet merkbaar aan de opbrengst van de bieten. Er lijkt wel een gunstige invloed op de bietvorm van uit te gaan.

De invloed van ploegdiepte en ondergrondbewerking is evenmin opvallend sterk. Wel heeft het $15 \mathrm{~cm}$ diep geploegde gedeelte een hogere opbrengst dan de beide andere ploegdiepten gegeven. 
De vorm van de bieten wordt zowel door het woelen als de diepere grondbewerking verbeterd.

De invloed van de hopperups komt tot uiting in een hogere opbrengst van koppen + blad, vergeleken met de objecten zonder hopperups.

De ongunstige invloed van de hopperups op de vorm van de bieten is eveneens duidelijk.

b. Het proefveld op kavel $\mathrm{O} 98$.

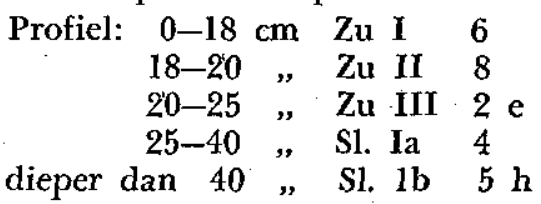

Dit profiel bestaat dus uit een bouwvoor van zware zavel, gescheiden van de lichte sloef-ondergrond door een dikke laag fijn zand. De kavel werd in maart en april 1949 gedraineerd en geëgaliseerd.

1. Op deze kavel werd eveneens de gecombineerde werking van de vernielploeg en de ploeg met ondergronders nagegaan op de groei van verschillende gewassen.

Hiertoe werd de kavel verdeeld in 5 blokken, elk van 14 akkers. Met de vernielploeg werden telkens 6 akkers bewerkt tot $60 \mathrm{~cm}$ diepte en 6 akkers tot $\pm 100 \mathrm{~cm}$ diepte (gewoeld). Om de invloed van de intensiteit van deze laatste bewerking na te gaan, werd bij elke diepte telkens op 2 akkers met een tussenruimte van $400 \mathrm{~cm}, 140 \mathrm{~cm}$ en $80 \mathrm{~cm}$ een sleuf getrokken. In elk blok bleven 2 akkers onbewerkt.

Daar de sleuven evenwijdig aan de drains werden getrokken, kon geen verbetering van de ontwatering worden verwacht. Wel werd de ondergrond min of meer losgemaakt.

In de lengterichting werd de kavel in drie lange vakken verdeeld. Twee vakken werden op de gewone wijze $(20 \mathrm{~cm}$ diep) geploegd. Eén vak werd geploegd met de ploeg met ondergronders (Mc. Cormick), met een diepte van $30 \mathrm{~cm}$ ploegen en $30 \mathrm{~cm}$ ondergronden (totale diepte $60 \mathrm{~cm})$.

Op de vijf blokken werden respectievelijk gezaaid: suikerbieten (Kuhn P), blauwmaanzaad, luzerne, hopperups en rode klaver.

Aansluitend aan het vak met suikerbieten werden nog drie stellen van twee akkers met suikerbieten ingezaaid, die respectievelijk: niet, op $140 \mathrm{~cm}$ en op $80 \mathrm{~cm}$ onderlinge afstand met de vernielploeg waren bewerkt, en alle in de lengterichting van de kavel de beide ploegbewerkingen hadden ondergaan.

De grondbewerking geschiedde nogal haastig, in een wat natte grond waarvan de structuur door het draineren en egaliseren en tijdens het sleuventrekken enigszins was bedorven. Het ploegen ging echter goed, zodat een redelijk zaaibed werd verkregen. Op de stroken met ondergrondbewerking was door het diepere ploegen een laag van de droge 
sloef bovengekomen en door de bouwvoor gemengd. Op deze strook is de stand der gewassen het gehele jaar slechter geweest.

Op de zes akkers met suikerbieten werd een proef aangelegd met opklimmende hoeveelheden stikstofmeststof, met de bedoeling te onderzoeken welke invloed de ondergrondbewerking heeft op de vruchtbaarheid van de grond. De gebruikte hoeveelheden waren $0,300,600,900$, 1200 en $1500 \mathrm{~kg} / \mathrm{ha}$ kas.

De suikerbieten haddden een enigszins holle stand. $\mathrm{Zij}$ toonden gedurende het groeiseizoen geen tekenen van verwelking.

$\mathrm{Bij}$ de oogst in oktober werden de volgende gegevens verkregen; zij geven de gemiddelden weer van vier herhalingen.

TABEL 18. Aantallen planten en schieters van suikerbieten op het ondergrondbewerkingsproefveld met opklimmende hoeveelheden stikstofmeststof op kavel $\mathrm{O} 98$ in 1949.

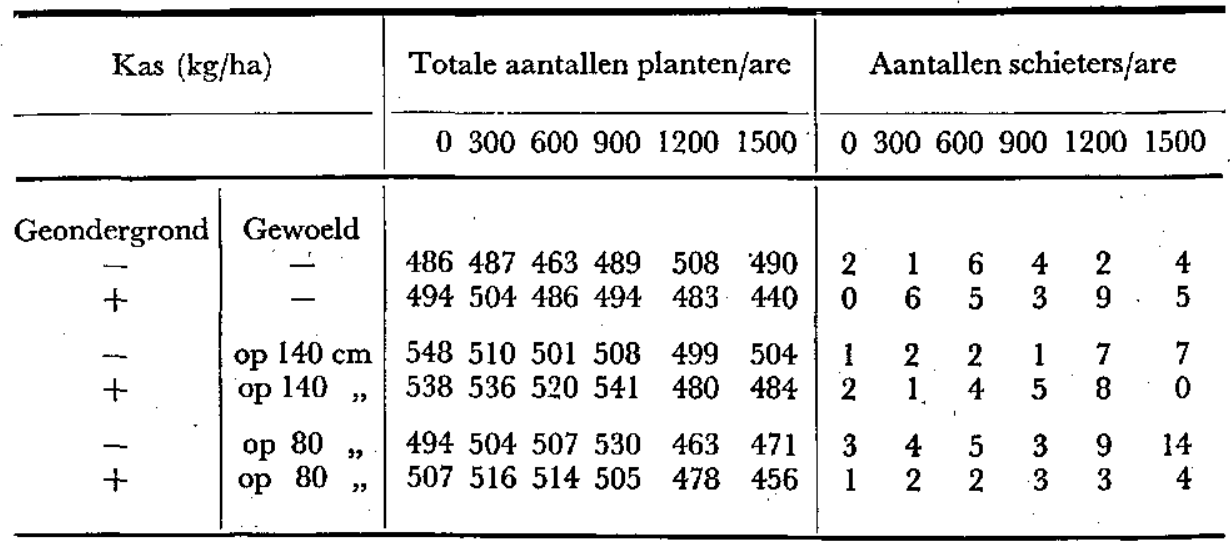

TABEL 19. Opbrengsten aan bieten en bietekoppen (kg/are) op het ondergrondbewerkingsproefveld met opklimmende hoeveelheden stikstof-meststof op kavel $O 98$ in 1949.

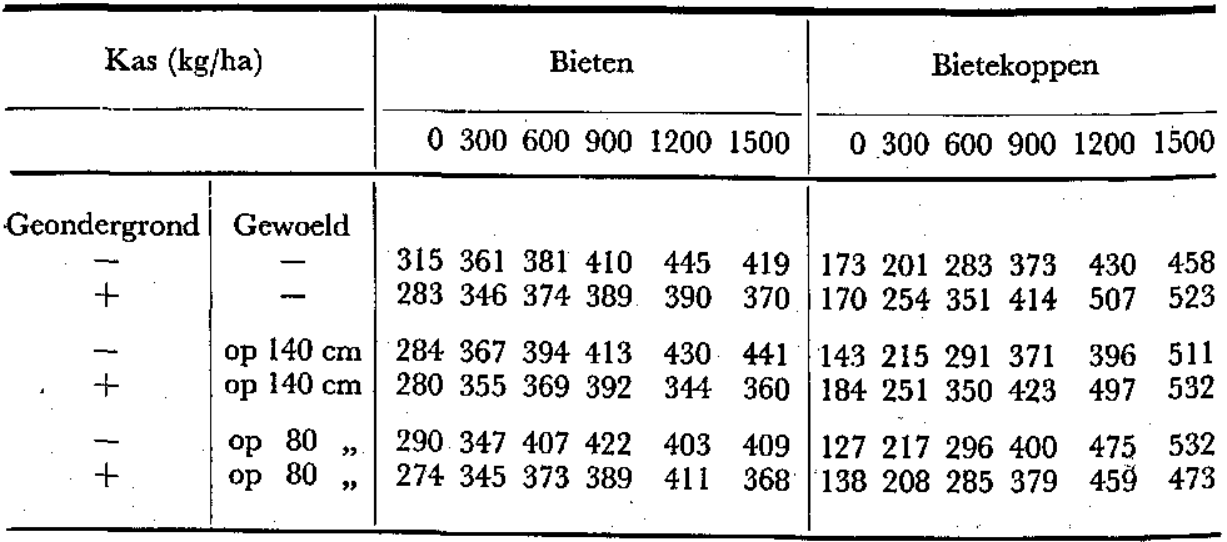


TABEL 20. De percentages afwijkende bietvormen op het ondergrondbewerkingsproefveld met opklimmende hoeveelheden stikstof-meststof op kavel O 98 in 1949.

\begin{tabular}{c|c|c|c}
\hline Geondergrond & Gewoeld & $300 \mathrm{~kg} / \mathrm{ha} \mathrm{kas}$ & $1200 \mathrm{~kg} / \mathrm{ha} \mathrm{kas}$ \\
\hline- & - & 20.8 & 21.1 \\
+ & - & 13.7 & 15.2 \\
& & 19.3 & 21.1 \\
+ & op $140 \mathrm{~cm}$ & 14.6 & 14.0 \\
- & op 140, & 21.8 & 20.0 \\
+ & op 80, & 12.7 & 12.2 \\
\hline
\end{tabular}

Bij de lagere stikstofgiften is het aantal bieten het grootst op de veldjes met ondergrondbewerking. $\mathrm{Bij}$ de twee hoogste stikstofbemestingen is het aantal op de niet geondergronde veldjes het hoogst.

De bietenopbrengst is op de geondergronde veldjes duidelijk lager dan op de niet geondergronde. Het woelen heeft geen invloed.

De koppenopbrengst is juist op het geondergronde gedeelte het hoogst, behalve bij het intensieve woelen.

Ten gevolge van de ondergrondbewerking is het aantal afwijkende bieten gedaald. De invloed van de stikstofbemesting en het woelen is te verwaarlozen.

De groei van de luzerne, hopperups en rode klaver was op het geondergronde gedeelte matig.

In oktober werd met behulp van naaldenplanken de beworteling van deze gewassen onderzocht op het niet en wel geondergronde gedeelte zonder woelsleuven.

In de profielen was de aëratietoestand als volgt:

Niet bewerkt

$0-40 \mathrm{~cm}$ volledig geaëreerd $40-60 \mathrm{~cm} 50 \%$ geaëreerd $>60 \mathrm{~cm}$ ongeaëreerd

\section{Geondergrond}

$0-50 \mathrm{~cm}$ volledig geaëreerd $50-80 \mathrm{~cm} 50-75 \%$ geaëreerd $>80 \mathrm{~cm}$ ongeaëreerd

In het niet bewerkte profiel was de wortelgroei op $\pm 20 \mathrm{~cm}$ diepte ernstig gestoord (fig. 52). De wortels gingen niet door de zandlaag heen. $\mathrm{Na}$ het ondergronden groeiden de wortels ongestoord tot ongeveer $60 \mathrm{~cm}$ diepte (fig. 53).

De zandlaag was door de bouwvoor gemengd en de daaronder liggende zandige sloef was gebroken. De zwaardere sloef rijpte uit zichzelf verder:

In het blauwmaanzaad werden geen waarnemingen verricht. 
2. In november 1949 werd de kavel in de lengterichting geploegd. De helft van de in het voorjaar met de Mc. Cormickploeg met ondergronders geploegde strook werd met deze ploeg bewerkt, evenals de helft van de aangrenzende strook die in het voorjaar normaal werd geploegd. De resterende helften van deze twee stroken werden normaal geploegd. Van de derde strook, die in het voorjaar normaal was geploegd, werd de helft weer normaal geploegd en de andere helft op $30 \mathrm{~cm}$ diepte.

Aldus ontstonden de volgende grondbewerkingsstroken.

\begin{tabular}{l|c|c|c|c|c|c} 
& $\mathrm{a}$ & $\mathrm{b}$ & $\mathrm{c}$ & $\mathrm{d}$ & $\mathrm{e}$ & $\mathrm{f}$ \\
Voorjaar 1949 & $20 \mathrm{~cm}$ & $20 \mathrm{~cm}$ & $20 \mathrm{~cm}$ & $20 \mathrm{~cm}$ & $30+30 \mathrm{~cm}$ & $30+30 \mathrm{~cm}$ \\
Najaar 1949 & $20 \mathrm{~cm}$ & $30 \mathrm{~cm}$ & $20 \mathrm{~cm}$ & $30+30 \mathrm{~cm}$ & $30+30 \mathrm{~cm}$ & $20 \mathrm{~cm}$
\end{tabular}

Op strook $\mathbf{b}$ kon de invloed van het diepere ploegen worden nagegaan, welke op de.stroken d, e en $f$ niet was te scheiden van de ondergrondbewerking.

Op de stroken $d$ en $f$ werd respectievelijk onder ongunstige omstandigheden (voorjaar 1949) en onder gunstige omstandigheden (najaar 1949) gewerkt.

Strook e gaf de mogelijkheid de invloed van een intensieve ondergrondbewerking na te gaan.

De Mc. Cormick met ondergronders ploegde $30-35 \mathrm{~cm}$ diep. Waar nog niet eerder was geondergrond kwam gedeeltelijk blauw gekleurde sloef boven en moest het zwaarst worden getrokken. Bij het $30 \mathrm{~cm}$ diep ploegen werd net over de sloef heen geploegd. De grond was nat en viel grof.

Het ploegen op diepten van 20 en $30 \mathrm{~cm}$ gebeurde na enige regendagen. De gewoelde akkers $(2,5$ en 9 sleuven) waren droger dan de niet gewoelde. Op deze laatste was de grond bijna modder. (Het bezwaar van dit soort proeven is, dat de grondbewerking niet voor elk object onder de gunstigste omstandigheden geschiedt).

In de winter bleken de gewoelde akkers steeds droger te zijn dan de niet gewoelde. Dit was echter alleen merkbaar op de stroken die niet waren geondergrond. De bovengeploegde sloef verslempte door de regen.

Eind maart 1950 werd de gehele kavel met cultivatoren bewerkt. De blokken werden respectievelijk ingezaaid met haver (na suikerbieten), zomertarwe (na blauwmaanzaad), suikerbieten (na luzerne), groene erwten (na hopperups) en blauwmaanzaad (na rode klaver). Het blauwmaanzaadblok werd naderhand wegens mislukken ingezaaid met gele mosterd.

De haver op de stroken zonder ondergrondbewerking en zonder woelsleuven, welke $20 \mathrm{~cm}$ diep waren geploegd, stond aanvankelijk beter dan op de stroken met ondergrondbewerking. Na juni veranderde dit; de haver werd geler en bleef wat achter in de massa. Met $30 \mathrm{~cm}$ ploegen was de kleur groener en op het tweemaal geondergronde gedeelte was 
het gewas het zwaarst. Het afrijpen begon het eerst op de stroken zonder ondergrondbewerking.

De opbrengst in $\mathrm{kg} /$ are was als volgt op de akkers zonder woelsleuven:

$\begin{array}{lccccc}\text { Bewerking voorjaar } 1949 & 20 \mathrm{~cm} & 20 \mathrm{~cm} & 30+30 \mathrm{~cm} & 20 \mathrm{~cm} & 30+30 \mathrm{~cm} \\ \text { Bewerking najaar 1949 } & 20 \mathrm{~cm} & 30 \mathrm{~cm} & 20 \mathrm{~cm} & 30+30 \mathrm{~cm} & 30+30 \mathrm{~cm} \\ & & & & & \\ \text { Korrel } & 34.5 & 33.1 & 38.4 & 37.1 & 38.3 \\ \text { Stro } & 47.2 & 43.7 & 50.4 & 49.5 & 51.9\end{array}$

De beworteling in de geondergronde stroken gaat dieper dan waar niet is geondergrond; dit gaat samen met een diepere aëratie.

De bouwvoor van de voor het eerst $30 \mathrm{~cm}$ geploegde stroken bevat duidelijk van elkaar te onderscheiden zavel- en sloef-gedeelten.

Waar in het voorjaar 1949 reeds $30 \mathrm{~cm}$ werd geploegd, zijn zavel en sloef goed gemengd.

De zomertarwe toonde gedurende het groeiseizoen een achterstand op de $20 \mathrm{~cm}$ geploegde stroken zonder ondergrondbewerking.

De opbrengst in $\mathrm{kg} /$ are was. op de akkers zonder woelsleuven:

$\begin{array}{lccccc}\text { Bewerking voorjaar } 1949 & 20 \mathrm{~cm} & 20 \mathrm{~cm} & 30+30 \mathrm{~cm} & 20 \mathrm{~cm} & 30+30 \mathrm{~cm} \\ \text { Bewerking najaar } 1949 & 20 \mathrm{~cm} & 30 \mathrm{~cm} & 20 \mathrm{~cm} & 30+30 \mathrm{~cm} & 30+30 \mathrm{~cm} \\ & & & & & \\ \text { Korrel } & 25.1 & 25.0 & 25.7 & 27.0 & 27.6 \\ \text { Stro } & 51.4 & 50.9 & 52.6 & 55.2 & 57.4\end{array}$

Het gedrag van de wortels en de aard van de bouwvoor kwamen geheel overeen met hetgeen bij de haver is beschreven.

In de suikerbieten was, evenals in 1949 , geen verschil in ontwikkeling tengevolge van een ondergrondbewerking te zien.

De gegevens over opbrengst en tarra zijn als volgt:

$\begin{array}{lcccccc}\text { Bewerking voorjaar 1949 } & & 20 \mathrm{~cm} & 20 \mathrm{~cm} & 30+30 \mathrm{~cm} & 20 \mathrm{~cm} & 30+30 \mathrm{~cm} \\ \text { Bewerking najaar } 1949 & & 20 \mathrm{~cm} & 30 \mathrm{~cm} & 20 \mathrm{~cm} & 30+30 \mathrm{~cm} & 30+30 \mathrm{~cm} \\ & & & & & & \\ \text { Bieten } & (\mathrm{kg} / \mathrm{a}) & 394 & 335 & 368 & 363 & 328 \\ \text { Bietenkoppen } & (\mathrm{kg} / \mathrm{a}) & 447 & 484 & 462 & 461 & 444 \\ \text { Normale bieten } & (\%) & 13 & 44 & 63 & 56 & 58 \\ \text { Korte bieten } & (\%) & 78 & 48 & 29 & 35 & 34 \\ \text { Vertakte bieten } & (\%) & 9 & 8 & 8 & 9 & 8 \\ \text { Grond-tarra } & (\%) & 9.1 & 8.8 & 8.0 & 7.9 & 7.4\end{array}$

De groene erwten en gele mosterd toonden evenals de overige gewassen op de $20 \mathrm{~cm}$ geploegde stroken zonder ondergrondbewerking een minder goede stand. De bloei en afrijping waren hier ook iets voorlijk.

De opbrengstbepaling van deze gewassen was niet betrouwbaar genoeg om te worden vermeld. 


\section{Samenvatting}

De drie bewerkingen die op dit proefveld werden toegepast, n.l. woelen in de akkerrichting, ondergronden dwars over de akkers en ploegen $(20$ en $30 \mathrm{~cm})$ dwars over de akkers, gaven de gelegenheid de afzonderlijke en gecombineerde invloed op de structuur van de bouwvoor en de groei van de gewassen na te gaan.

Door het woelen werd een betere ontwatering van de bouwvoor verkregen, vermoedelijk niet omdat het water kon worden afgevoerd, maar omdat de berging in de grond groter werd.

Het ondergronden gaf een betere ontwatering. Dat inderdaad de afvoer kon zijn verbeterd; bleek nog bij het profielonderzoek, dat aantoonde dat de ondergronders van de Mc. Cormickploeg een soort molploegwerking hadden.

Het onvermijdelijk diepere ploegen van de Mc. Cormickploeg gaf een ongewenste vermenging van sloef door de bouwvoor. De bouwvoor werd hierdoor lichter (lager lutumgehalte) en slempiger (hoger zandgehalte). De menging van verse ondergrond door de bouwvoor gaf lagere opbrengsten. Een herhaalde ondergrondbewerking had een goed gevolg, waarschijnlijk ook omdat een betere menging in de bouwvoor hiervan het gevolg was. De vorm van de bieten was de grootste verbetering die de ondergrondbewerking gaf. Dit kwam enigszins tot uiting in de lagere grondtarra.

Bij de opzet van dit proefveld was het niet mogelijk de betere ontwateringstoestand ten gevolge van het ondergronden te benutten.

$\mathrm{Bij}$ de meeste bewerkingen werd gewacht tot de natste stroken in een enigszins redelijke toestand verkeerden, met als gevolg dat de drogere gedeelten later werden bewerkt en ingezaaid dan nodig was. Daardoor kon niet worden geprofiteerd van de voordelen van een zeer vroege zaaitijd.

$\mathrm{Bij}$ de oogst kwamen de voordelen van de drogere stroken evenmin geheel tot uiting.

De verbetering van de aëratie en de doorworteling van de grond waren zeer duidelijk.

\section{c. De proefvelden op kavel M 128 .}

Profiel: 20 à $30 \mathrm{~cm} \mathrm{Zu} \mathrm{I} \mathrm{gr.} 6$ (voorop de kavel $30 \mathrm{~cm}$, achterop de kavel $20 \mathrm{~cm}$ ), dieper dan $30 \mathrm{~cm}$ pleistoceen zand (voorop A.B.C.-profiel, achterop alleen $\mathrm{C}$ ).

Dit profiel bestaat dus uit een bouwvoor van zware zavel, rustend op zand. Het zand bevat een meer of minder volledig A.B.C.-profiel. De kavel staat aan de noordzijde onder invloed van de Kuindervaart, die een grondwaterstandsverlaging veroorzaakt in de richting van zuid naar noord. Daar de zavellaag naar het noorden toe dunner wordt, is er steeds een groot verschil in de ontwikkeling der gewassen van het zuiden naar het noorden. 
1. De Bodemkundige Afdeling van de Directie der Noordoostpolderwerken legde in 1948 op deze kavel een proefveld aan waarin op verschillende manieren de zandondergrond werd losgemaakt of gemengd met een gedeelte van de bouwvoor.

In de lengterichting werd de kavel als volgt bewerkt:

a. woelsleuven van $70 \mathrm{~cm}$ diepte met een tussenruimte van $75 \mathrm{~cm}$, met de vernielploeg;

b. ploegen tot $60 \mathrm{~cm}$ diepte, waarbij $10 \mathrm{~cm}$ van de bouwvoor werd bovengehouden;

c. ploegen tot $40 \mathrm{~cm}$ diepte;

d. ploegen tot $25 \mathrm{~cm}$ diepte en ondergronden tot $40 \mathrm{~cm}$ diepte;

e. ploegen tot $25 \mathrm{~cm}$ diepte.

Op verschillende manieren werd dus getracht hetzij het zand alleen los te maken, hetzij het zand los te maken en dit tevens enigszins te mengen met de zware zavel.

In 1948 en 1949 werd op deze kavel haver verbouwd, in 1951 wintertarwe.

De gewassen werden met een maaidorsmachine geoogst op negen stroken dwars op de grondbewerkingsrichting. Deze stroken werden drie aan drie gecombineerd voor een gemiddelde opbrengstberekening van de verschillende grondbewerkingen. In de tabellen zijn de korrelopbrengsten vermeld per grondbewerking, afzonderlijk voor het voorste, het middelste en het achterste gedeelte van de kavel.

De gemiddelde grondwaterstanden in juli zijn opgenomen voor de jaren 1950 en 1951 .

TABEL 21. Opbrengsten (kg/are) van de drie delen van het ondergrondbewerkingsproefveld op kavel M 128 in de jaren 1948, 1949 en 1951.

\begin{tabular}{|c|c|c|c|c|c|c|}
\hline \multirow{2}{*}{ Gewas } & \multicolumn{5}{|c|}{ Grondbewerking } & \multirow{2}{*}{$\begin{array}{l}\text { Grond- } \\
\text { water- } \\
\text { stand }\end{array}$} \\
\hline & $20 \mathrm{~cm}$ & $25+15 \mathrm{~cm}$ & $40 \mathrm{~cm}$ & $60 \mathrm{~cm}$ & $\begin{array}{l}.70 \mathrm{~cm} \\
\text { woelen }\end{array}$ & \\
\hline $\begin{array}{l}1948 \text { Haver } \\
\text { voor } \\
\text { midden } \\
\text { achter }\end{array}$ & $\begin{array}{l}27.6 \\
23.9 \\
16.9\end{array}$ & $\begin{array}{l}29.1 \\
22.8 \\
17.3\end{array}$ & $\begin{array}{l}29.2 \\
23.6 \\
19.6\end{array}$ & $\begin{array}{l}29.9 \\
26.6 \\
21.2\end{array}$ & $\begin{array}{l}31.8 \\
27.3 \\
21.6\end{array}$ & \\
\hline $\begin{array}{l}1949 \text { Haver } \\
\text { voor } \\
\text { midden } \\
\text { achter }\end{array}$ & $\begin{array}{l}51.4 \\
38.3 \\
36.6\end{array}$ & $\begin{array}{l}53.9 \\
42.5 \\
39.1\end{array}$ & $\begin{array}{l}54.9 \\
43.1 \\
39.0\end{array}$ & $\begin{array}{l}52.7 \\
44.8 \\
41.3\end{array}$ & $\begin{array}{l}51.6 \\
43.5 \\
39.7\end{array}$ & $\begin{array}{l}-113 \mathrm{~cm} \\
-164 " \\
-200 "\end{array}$ \\
\hline $\begin{array}{l}1951 \text { Wintertarwe } \\
\text { voor } \\
\text { middex } \\
\text { achter }\end{array}$ & $\begin{array}{l}34.6 \\
31.9 \\
23.9\end{array}$ & $\begin{array}{l}36.9 \\
30.6 \\
25.4\end{array}$ & $\begin{array}{l}35.9 \\
31.7 \\
25.8\end{array}$ & $\begin{array}{l}35.5 \\
32.5 \\
27.1\end{array}$ & $\begin{array}{l}36.3 \\
32.6 \\
27.2\end{array}$ & $\begin{array}{l}94 " \\
-123 " \\
-177 "\end{array}$ \\
\hline
\end{tabular}


De regenval was in deze jaren als volgt:

\begin{tabular}{|c|c|c|c|c|}
\hline & 1948 & 1949 & $\begin{array}{c}1950 \\
65 \mathrm{~mm}\end{array}$ & $\begin{array}{c}1951 \\
50 \mathrm{~mm}\end{array}$ \\
\hline Jun & 60 & $25 \quad$ & 30 " & 40 \\
\hline Juli & 70 & 25 & 90 & 60 \\
\hline
\end{tabular}

De opbrengst van de gewassen correleerde sterk met de grondwaterstand, de dikte van de zavellaag en het voorkomen van A- en B-horizonten in het zand. Daar deze factoren voor op de kavel gunstig zijn en achterop ongunstig, is hun afzonderlijke invloed niet na te gaan. De vermelde opbrengsten zijn samengesteld uit 6 of 12 herhalingen, welke echter alle een dermate grote spreiding toonden, dat uit het cijfermateriaal alleen geconcludeerd kan worden dat de diepste grondbewerkingen, hetzij ploegen hetzij woelen, de opbrengst gunstig beinvloeden. Deze invloed is achter op de kavel (waar de omstandigheden het ongunstigst zijn) het grootst. Het is echter onvoldoende om de opbrengst op het niveau van het middelste gedeelte van de kavel te brengen.

De bewortelingsdiepte van de gewassen bleef in alle gevallen beperkt tot de bewerkingsdiepte.

2. Ter nadere bestudering van het effect van losmaken van het zand of mengen van het zand met zavel werd achter op de kavel op een gedeelte waar geen of zo weinig mogelijk bruin zand (B-horizont) voorkwam, een proefveld aangelegd met de volgende objecten:

a. $25 \mathrm{~cm}$ spitten;

b. $25 \mathrm{~cm}$ spitten en $15 \mathrm{~cm}$ losmaken;

c. $25 \mathrm{~cm}$ spitten en $35 \mathrm{~cm}$ losmaken;

d. $40 \mathrm{~cm}$ spitten met zo goed mogelijk mengen;

e. $40 \mathrm{~cm}$ spitten en mengen en $20 \mathrm{~cm}$ losmaken;

f. $60 \mathrm{~cm}$ spitten en zo goed mogelijk mengen.

Deze objecten lagen in vier banen, binnen elke baan volgens toeval verdeeld. Grootte van de veldjes: $10 \times 10 \mathrm{~m}^{2}$.

De grondbewerking veroorzaakte door het mengen een andere samenstelling van de bouwvoor en van de ondergrond.

Het lutumgehalte en het U-cijfer werden als volgt:
a. $12.2 \%$ Iutum, U-cijfer 221
b. $10.7, \quad, \quad, \quad 187$
c. $8.7, ", \quad, \quad 160$
d. $5.5, \quad, \quad, 130$
e. $6.1, \quad, \quad, \quad 118$
f. $4.8, \quad, \quad$, 109

De objecten $a, b$ en $c$ en de objecten d en e behoorden onderling dezelfde samenstelling te hebben, omdat de grondbewerking ten aanzien 
van de bouwvoor gelijk was. Bij het losmaken van de ondergrond was, wegens het overzetten van de bouwvoor, een lichte vermenging met het zand niet te vermijden. Bovendien werd door het maken van een bouwvoor van $25 \mathrm{~cm}$ reeds een zandlaagje van $5 \mathrm{~cm}$ dikte door de laag zavel van $20 \mathrm{~cm}$ gemengd.

Volgens de gegevens van VecDman ligt het lutumgehalte van de objecten a en b (en c) nog boven de grens waarop de grond gevoelig wordt voor stuiven.

In 1950 werden op dit proefveld voederbieten verbouwd.

De opkomst van de bieten op object $f$ gaf enige moeilijkheden, daar wegens de droogte en iets stuiven het kiemen traag verliep en enige beschadiging van de kiemplantjes voorkwam.

Op 9 augustus werd na een aantal zeer warme en droge dagen de toestand van het loof opgenomen. Met een waarderingsschaal van $1=$ geheel slap op de grond, $10=$ geheel fris, kwamen de volgende beoordelingen voor den dag:

$\begin{array}{ccccccc}\text { Objecten } & a & b & c & d & e & f \\ & (25 \mathrm{~cm}) & (25+15 \mathrm{~cm}) & (25+35 \mathrm{~cm}) & (40 \mathrm{~cm}) & (40+20 \mathrm{~cm}) & (60 \mathrm{~cm}) \\ \text { Frisheid } & 1.5 & 2 & 6.5 & 7 & 8 & 9\end{array}$

Op de objecten a en b bleven de planten 's nachts ook slap.

Na enige regen herstelden alle planten zich.

Bij de oogst op 6 oktober werd het aantal planten per veldje geteld en werden de gewichten van de bieten en koppen + loof bepaald.

De gemiddelde aantallen en opbrengsten per are zijn als volgt:

TABEL 22. Opbrengst-gegevens (in aantallen en $\mathrm{kg} / \mathrm{are}$ ) van de voederbieten op de onderscheidene objecten van het grondbewerkingsproefveld op kavel M 128 in 1950.

\begin{tabular}{|c|c|c|c|c|c|}
\hline Object & Bewerking & Aantal & Bieten & $\begin{array}{c}\text { Koppen } \\
\text { loof }\end{array}$ & Totaal \\
\hline $\begin{array}{l}\mathbf{a} \\
\mathrm{b} \\
\mathrm{c} \\
\mathrm{d} \\
\mathrm{e} \\
\mathrm{f}\end{array}$ & $\begin{array}{r}25 \mathrm{~cm} \\
25+15 " \\
25+35 " \\
40 " \\
40+20 " \\
60 "\end{array}$ & $\begin{array}{l}647 \\
623 \\
635 \\
606 \\
633 \\
592\end{array}$ & $\begin{array}{l}630 \mathrm{~kg} / \mathrm{a} \\
643 \quad " \\
650 " \\
638 \text { " } \\
680 \text { " } \\
626 \text { ", }\end{array}$ & $\begin{array}{l}170 \mathrm{~kg} / \mathrm{a} \\
190 " \\
202 " \\
196 " \\
214 " \\
206 "\end{array}$ & $\begin{array}{l}800 \mathrm{~kg} / \mathrm{a} \\
833 \text { " } \\
852 " \\
834 \\
894 " \\
832 "\end{array}$ \\
\hline
\end{tabular}

$\mathrm{Na}$ berekening bleek, dat object e betrouwbaar beter was dan de objecten a en f; verder waren geen betrouwbare verschillen aanwezig. De bietenwortels kwamen alleen voor in de losgemaakte en de gemengde grond. In het profiel leek de beworteling in de gemengde grond dichter dan in het losgemaakte zand. 
In de herfst van 1950 werd op dit proefveld Carsten's V wintertarwe gezaaid. De bezakte bouwvoor en de voldoende vochtigheid van de grond gaven een gelijkmatige opkomst en standdichtheid over het gehele proefveld. Het proefveld bleef gelijkmatig tot in het voorjaar.

Tijdens een droge, warme periode (eind mei begin juni) bleven de planten op de a-objecten achter in Iengtegroei, terwijl de onderste bladeren begonnen te verdorren. In het schotblad-stadium (half juni) waren de planten op de a-objecten kort, dor en hadden veel afgestorven blad.

Op de objecten e en $\mathrm{f}$ waren de planten het best. De lengte van de planten op de a-objecten was toen $\pm 50 \mathrm{~cm}$, tegen $75 \mathrm{~cm}$ op de objecten e en $f$.

Op 16 augustus werd de tarwe gezicht.

TABEL 23. Korrel- en stro-opbrengsten (kg/are) van de wintertarwe op de objecten van het grondbewerkingsproefveld op kavel M 128 in 1951.

\begin{tabular}{c|r|l|l|l}
\hline Object & Bewerking & Korrel & Stro & Totaal \\
\hline & $25 \mathrm{~cm}$ & 23.4 & 29.6 & 53 \\
a & $25+15 "$ & 25.2 & 34.0 & 59.2 \\
b & $25+35 "$ & 30.2 & 38.9 & 69.1 \\
c & $40 "$ & 26.6 & 36.4 & 63.0 \\
e & $40+20 "$ & 29.9 & 40.1 & 70.0 \\
f & $60 "$ & 32.1 & 44.8 & 76.8 \\
\hline
\end{tabular}

Volgens berekeningen is er bij de korrelopbrengsten geen betrouwbaar verschil tussen de objecten c en e; bij de stro-opbrengsten niet tussen de objecten b en d, c en d, $c$ en e; en bij de totale opbrengsten niet tussen de objecten $b$ en $d, c$ en e.

De overige verschillen tussen de objecten zijn zeer betrouwbaar, behalve bij het stro tussen $d$ en e, waar het verschil slecht betrouwbaar is.

De profielen waren doorworteld tot hoogstens $10 \mathrm{~cm}$ beneden de grens van de bewerking. In het losgemaakte zand kwamen geen verdikte wortels of worteltoppen voor. Wel waren de wortels in de zavelkluiten dunner dan in het zand. Het zand tussen de zavelkluiten leek op het oog minder dicht doorworteld te zijn dan de zavel.

\section{Samenvatting}

Op de grondbewerkingsproefvelden op kavel M 128 bleek, dat een diepere beworteling kon worden verkregen door het zand onder de bouwvoor los te maken of te mengen met de zavel van de bouwvoor.

De diepte tot waar het zand is losgemaakt of gemengd of gedeeltelijk gemengd en losgemaakt, is vermoedelijk belangrijker dan de wijze waarop het zand werd losgemaakt en/of gemengd. 
De voederbieten in 1950 gaven op het object e $(40+20 \mathrm{~cm})$ de hoogste opbrengst. Dat object $\mathbf{f}(60 \mathrm{~cm})$ hier achterbleef, is vermoedelijk veroorzaakt door de achterstand die het gewas had ten gevolge van een latere opkomst en dunnere stand.

De wintertarwe in $195 \mathrm{I}$ had de hoogste opbrengsten op object $\mathrm{f}$.

Mengen van zand en zavel schijnt in dit geval iets gunstiger te kunnen zijn dan alleen maar losmaken.

Ook uit de gegevens van het proefveld dat over de gehele kavel was aangelegd, is het niet mogelijk aan te geven, aan welke bewerking de voorkeur dient te worden gegeven. In het algemeen moet een zodanig zware bouwvoor in stand worden gehouden, dat geen stuif- of droogteschade in het voorjaar kan worden verwacht.

In geen van de proeven is het gelukt een normale opbrengst te verkrijgen.

De kavel wordt nu door infiltratie van water voorzien.

d. Het proefveld op kavel B 68 .

Profiel: $\left.\begin{array}{clll}0-20 \mathrm{~cm} & \text { bouwvoor } & \text { gr. } 4 \\ 20-38 & \text { " Espelzand } & \text { gr. } 2 \mathrm{~d}\end{array}\right\} \mathrm{Zu}$ I en III

Het profiel bestaat dus uit een bouwvoor van lichte zavel, rustend op een ondergrond van fijn zand waarin zich nog een laagje lichte zavel bevindt.

1. In december 1951 werden in de lengterichting van deze kavel, na het draineren en vlak ploegen, twee stroken op $20 \mathrm{~cm}$ diepte geploegd en 2 stroken met de Mc. Cormickploeg met ondergronders $\pm 25 \mathrm{~cm}$ diep geploegd en $\pm 35 \mathrm{~cm}$ daaronder losgemaakt. De normaal geploegde en de geondergronde stroken lagen om en om.

Dwars over deze stroken, in de richting van de akkers, werden in het voorjaar telkens twee akkers ingezaaid met luzerne, vezel-vlas (Concurrent), groene erwten (Rondo), suikerbieten (Kuhn P), haver (Marne), zomertarwe (Koga) en zomergerst (Agio).

Daar de voorvrucht jonge luzerne was, werden de volgende hoeveelheden kalkammonsalpeter gegeven: suikerbieten $600 \mathrm{~kg} / \mathrm{ha}$, haver en zomergerst $100 \mathrm{~kg} / \mathrm{ha}$ en zomertarwe $200 \mathrm{~kg} / \mathrm{ha}$.

Alle gewassen ontvingen $300 \mathrm{~kg} / \mathrm{ha}$ superfosfaat.

De bouwvoor op de geondergronde stroken maakte gedurende de winter een drogere indruk dan de normaal geploegde stroken.

De gewassen op de geondergronde stroken hadden een regelmatige stand. 
Het vlas was op de normaal geploegde stroken zwaarder, evenals de erwten.

De bieten en de zomergranen waren op de geondergronde stroken beter ontwikkeld.

TABEL 24. De gemiddelde opbrengsten (kg/are) op het ondergrondbewerkingsproefveld op kavel B 68 in 1952.

\begin{tabular}{l|c|cc|cc}
\hline Grondbewerking: & Kas (kg/ha) & Korrels of bieten & \multicolumn{2}{|c}{ Stro of bietekoppen } \\
\hline & & & & \\
Gewas & & $20 \mathrm{~cm}$ & $20+35 \mathrm{~cm}$ & $20 \mathrm{~cm}$ & $25+35 \mathrm{~cm}$ \\
& & & & & \\
\hline & 0 & - & - & 59.9 & 65.9 \\
Vlas & 0 & 49.3 & 48.0 & 39.9 & 41.7 \\
Groene erwten & 600 & 526 & 548 & 260 & 257 \\
Suikerbieten & 100 & 33.2 & 36.2 & 32.1 & 35.7 \\
Haver & 200 & 37.6 & 39.9 & 38.5 & 42.4 \\
Zomertarwe & 100 & 31.1 & 32.8 & 24.9 & 28.6 \\
Zomergerst & & & & & \\
\hline
\end{tabular}

Uit deze opbrengsten blijkt, dat de stikstofbemesting te laag is geweest. De opbrengst der gewassen was op het geondergronde deel hoger dan op het normaal geploegde, alleen bij de groene erwten toont de zaadopbrengst het tegenovergestelde beeld. Het betrekkelijk kleine verschil bij deze hoge erwtenopbrengst kan het gevolg zijn van een weligere loofontwikkeling, die bij de groene erwten de zaadopbrengst vaak nadelig beïnvloedt. De beworteling op de $20 \mathrm{~cm}$ geploegde stroken was tot $\pm 25 \mathrm{~cm}$ zeer dicht, daaronder zeer dun tot sporadisch, met een grootste diepte van $\pm 50 \mathrm{~cm}$.

In de geondergronde stroken nam de bewortelingsdichtheid regelmatig af van de bouwvoor tot $\pm 60 \mathrm{~cm}$ diepte.

De aëratie van de normaal geploegde strook was tot $\pm 35 \mathrm{~cm}$ diepte volledig en beneden $55 \mathrm{~cm}$ diepte afwezig.

In de geondergronde strook was tot $\pm 45 \mathrm{~cm}$ diepte een volledige aëratie tot stand gekomen; beneden $60 \mathrm{~cm}$ diepte was de aëratie afwezig. De tussenliggende zones waren in het geondergronde gedeelte sterker geaëreerd dan in de normaal geploegde strook.

2. In de herfst werd van elke grondbewerkingsstrook de helft bewerkt met de Neptunus op een diepte van $\pm 70 \mathrm{~cm}$. Daarna werd het gehele proefveld geploegd op $20 \mathrm{~cm}$ diepte. De volgende grondbewerkingscombinaties waren nu in tweevoud aanwezig:

1. normaal ploegen;

2. normaal ploegen met ondergrondbreken tot $70 \mathrm{~cm}$ diepte; 
3. ploegen met ondergronders (Mc. Cormick);

4. ploegen met ondergrondders en ondergrondbreken tot $70 \mathrm{~cm}$ diepte. Op een van de dubbele akkers werd wintertarwe gezaaid (Heine's VII) in plaats van zomertarwe en verder werden dezelfde gewassen gezaaid als in 1952.

De wintertarwe kreeg door ratten-, muizen- en vogelschade een zeer holle stand, die enigszins gecompenseerd werd door een zeer sterke uitstoeling.

De suikerbieten hadden een enigszins holle stand en hadden te lijden van luizen.

Verschillen in ontwikkeling op de grondbewerkingsstroken werden niet opgemerkt.

TABEL 25. De gemiddelde opbrengsten (kg/are) op het ondergrondbewerkingsproefveld op kavel B 68 in 1953.

\begin{tabular}{|c|c|c|c|c|c|}
\hline \multicolumn{2}{|c|}{$\begin{array}{c}\text { Grondbewerking 1952: } \\
, " 1953:\end{array}$} & $\begin{array}{l}20 \mathrm{~cm} \\
20 \mathrm{~cm}\end{array}$ & $\begin{array}{c}20 \mathrm{~cm} \\
\text { Neptunus }\end{array}$ & $\begin{array}{l}25+35 \mathrm{~cm} \\
\text { Neptunus }\end{array}$ & $\begin{array}{c}25+35 \mathrm{~cm} \\
20 \mathrm{~cm}\end{array}$ \\
\hline \multirow[t]{2}{*}{ Gewas } & $\mathrm{Kas}(\mathrm{kg} / \mathrm{ha})$ & \\
\hline & & \multicolumn{4}{|c|}{ a. Opbrengst korrels of bieten } \\
\hline Haver (Marne) & 300 & 49.7 & 51.8 & 52.6 & 52 \\
\hline $\begin{array}{l}\text { Wintertarwe } \\
\text { (Heine's VII) }\end{array}$ & 600 & 44.4 & 44.4 & 44.0 & 46.4 \\
\hline $\begin{array}{l}\text { Zomergerst } \\
\text { (Agio) }\end{array}$ & 350 & 39.6 & 40.2 & 39.5 & 40.1 \\
\hline $\begin{array}{l}\text { Vlas } \\
\text { (Concurrent) }\end{array}$ & 150 & & & - & - \\
\hline $\begin{array}{l}\text { Groene erwt } \\
\text { (Rondo) }\end{array}$ & & 38.1 & 39.4 & 39.8 & 40.- \\
\hline \multirow{2}{*}{$\begin{array}{l}\text { Suikerbiet } \\
\text { (KleinWanzlebenE) }\end{array}$} & 800 & 609 & 587 & 593 & 622 \\
\hline & & \multicolumn{4}{|c|}{ b. Opbrengst stro of loof } \\
\hline Haver & & 47.7 & 50.3 & 51.2 & 51.9 \\
\hline Wintertarwe & & 48.7 & 46.3 & 49.1 & 49.- \\
\hline Zomergerst & & 38.8 & 39.3 & 39.1 & 39.7 \\
\hline Vlas & & 73.7 & 73.5 & 73.7 & 75.3 \\
\hline Groene erwt & & - & - & - & - \\
\hline Suikerbiet & & 330 & 316 & 294 & 325 \\
\hline
\end{tabular}

De opbrengsten in tweevoud, waarvan bovenstaande tabel het gemiddelde weergeeft, hadden een dusclanige spreiding, dat de verschillen tussen de grondbewerkingen onbetrouwbaar zijn.

Met behulp van naaldenplanken werd de beworteling van de zomergerst onderzocht. Daar deze bemonstering evenwijdig aan de rijen werd uitgevoerd en dus de bepaalde wortelhoeveelheden in de bouwvoor en 
de ondergrond niet vergelijkbaar zijn (vgl. de hoofdstukken I en IV), wordt evenals in hoofdstuk IV de wortelverdeling in de ondergrond gegeven in procenten van de totale hoeveelheid wortels in de ondergrond.

TABEL 26. De wortelverdelingen (\%) van de zomergerst op het ondergrondbewerkingsproefveld op kavel B 68 in 1953, in de blokken van $10 \times 23 \times 50$ $\mathrm{cm}^{3}$.

\begin{tabular}{c|c|c|c|c}
\hline $\begin{array}{c}\text { Grondbewerking 1951: } \\
\text { 1952: }\end{array}$ & $\begin{array}{c}20 \mathrm{~cm} \\
20 \mathrm{~cm}\end{array}$ & $\begin{array}{c}20 \mathrm{~cm} \\
\text { Neptunus }\end{array}$ & $\begin{array}{c}25+35 \mathrm{~cm} \\
\text { Neptunus }\end{array}$ & $\begin{array}{c}25+35 \mathrm{~cm} \\
20 \mathrm{~cm}\end{array}$ \\
\hline $20-30 \mathrm{~cm}$ & 100 & 21 & 27 & 25 \\
$30-40 "$ & 0 & 26 & 14 & 35 \\
$40-50 "$ & 0 & 33 & 44 & 24 \\
$50-60 "$ & 0 & 15 & 5 & 12 \\
$60-70 "$ & 0 & 5 & 10 & 4 \\
$20-70$, & $212 \mathrm{mg}$ & $1201 \mathrm{mg}$ & $747 \mathrm{mg}$ & $1038 \mathrm{mg}$ \\
\hline
\end{tabular}

In juni werd de beworteling van de gewassen onderzocht in profielkuilen.

De gewassen hadden over het algemeen in de niet losgemaakte ondergrond enkele wortels die tot $\pm 50 \mathrm{~cm}$ diepte kwamen. In de wel losgemaakte ondergrond nam de bewortelingsdichtheid van bouwvoor naar ondergrond niet plotseling af, maar geleidelijk. De grootste diepte bedroeg $60-70 \mathrm{~cm}$. Het verschil in wortelhoeveelheid tussen nièt en wel geondergrond is zeer groot.

Dit proefveld werd in 1954 wegens verpachting niet meer aangehouden.

\section{Samenvatting}

Op het ondergrondbewerkingsproefveld op kavel B 68 werd in 1952 en 1953 de invloed van het losmaken van de ondergrond nagegaan op de opbrengst en de beworteling van een aantal gewassen. In 1952 was de opbrengst op de stroken met ondergrondbewerking hoger dan op de stroken zonder ondergrondbewerking. In 1953 was er geen verschil.

De beworteling en de aëratie van de grond werden beter na de ondergrondbewerking.

e. Het proefveld op kavel C 62

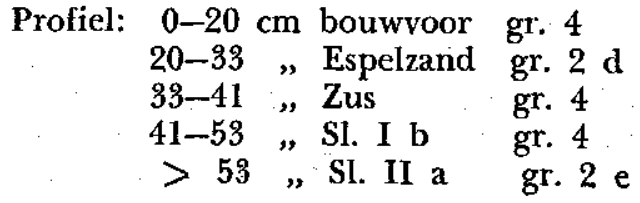


Dit profiel komt overeen met dat op kavel B 68 door de lichte-zavelbouwvoor, rustend op een zandlaag. Deze zandlaag is echter op kavel C 62 dunner, terwijl de sloef onder de Zus-afzetting een hoger lutumgehalte heeft. De ondergrond van kavel C 62 is dus wat gunstiger.

1. In het-voorjaar van 1952 werd op deze kavel na drainage en vlakploegen een grondbewerking toegepast als op kavel B 68, n.l. gewoon ploegen $\pm 20 \mathrm{~cm}$ diep en $\pm 25 \mathrm{~cm}$ diepploegen en tegelijkertijd de ondergrond tot $\pm 60 \mathrm{~cm}$ diepte losmaken. Tijdens deze bewerking was de grond nat. Dwars over deze grondbewerking werden ook weer in de richting van de akkers dezelfde gewassen gezaaid als op kavel B 68 . Daar de voorvrucht een goede rode klaver was, werd de stikstofbemesting van deze gewassen lager gehouden dan op B 68 en wel, voorzover er een stikstofbemesting werd toegepast, $100 . \mathrm{kg} / \mathrm{ha}$ kas minder. Alle gewassen ontvingen $300 \mathrm{~kg} / \mathrm{ha}$ superfosfaat.

Hoewel tijdelijk vlas en zomergerst op de geondergronde stroken beter stonden dan op de niet geondergronde stroken en de groene erwten tijdelijk beter stonden op de niet losgemaakte stroken, waren verder gedurende het grootste gedeelte van het groeiseizoen geen verschillen tussen de gewassen op de verschillend bewerkte stroken te zien.

TABEL 27. De gemiddelde opbrengsten (kg/are) op het ondergrondbewerkingsproefveld op kavel C 62 in 1952.

\begin{tabular}{l|c|cc|cc}
\hline Grondbewerking: & & $20 \mathrm{~cm}$ & $25+35 \mathrm{~cm}$ & $20 \mathrm{~cm}$ & $25+35 \mathrm{~cm}$ \\
\hline Gewas & Kas (kg/ha) & Korrels of bieten & Stro of bietekoppen \\
\hline $\begin{array}{l}\text { Vlas } \\
\text { (Concurrent) }\end{array}$ & 0 & - & - & 83.0 & 82.0 \\
$\begin{array}{c}\text { Groene erwt } \\
\text { (Rondo) }\end{array}$ & 0 & 47.6 & 44.4 & 31.6 & 31.1 \\
$\begin{array}{c}\text { Suikerbiet } \\
\text { (Kuhn P) }\end{array}$ & 500 & 647 & 629 & 279 & 264 \\
$\begin{array}{c}\text { Haver } \\
\text { (Marne) }\end{array}$ & 0 & 38.6 & 39.2 & 35.5 & 36.9 \\
$\begin{array}{c}\text { Zomertarwe } \\
\text { (Koga) }\end{array}$ & 100 & 34.6 & 35.3 & 34.2 & 37 \\
$\begin{array}{l}\text { Zomergerst } \\
\text { (Agio) }\end{array}$ & 0 & 29.9 & 30.8 & - & - \\
\hline
\end{tabular}

Voor de granen had de stikstofbemesting zwaarder kunnen zijn.

De gemiddelden zijn berekend uit vier bepalingen. De spreiding was evenwel zodanig, dat aan de hogere of lagere gemiddelden van bepaalde grondbewerkingen weinig waarde kan worden toegekend. 
In augustus werden de beworteling en de rijping van de grond bekeken, nadat het proefveld reeds een stoppelbewerking had ondergaan.

In de geondergronde stroken was de beworteling onder de bouwvoor dichter dan in de gewoon geploegde grond. De bewortelingsdiepte was voor de stroken respectievelijk $\pm 60 \mathrm{~cm}$ en $\pm 40 \mathrm{~cm}$.

De volledige aëratie was gevorderd van $\pm 40 \mathrm{~cm}$ tot $\pm 50 \mathrm{~cm}$ diepte, en de gedeeltelijke aëratie van $\pm 50 \mathrm{~cm}$ tot $\pm 60 \mathrm{~cm}$ diepte.

2. In het voorjaar van $\mathbf{1 9 5 3}$ werd de helft van alle grondbewerkingsstroken met de Neptunus tot $\pm 70 \mathrm{~cm}$ diepte losgemaakt. Daarna werden dezelfde gewassen gezaaid als in 1952; ze ontvingen echter een zwaardere stikstofbemesting.

Ook dit jaar werden geen verschillen in gewasontwikkeling opgemerkt bij de verschillende grondbewerkingen. Alleen het vlas heeft na zware regen tijdelijk gelegerd op de stroken met ondergrondbewerking, terwijl het op de normaal geploegde gedeelten steeds bleef staan.

TABEL 28. Gemiddelde opbrengsten ( $\mathrm{kg} / \mathrm{are}$ ) op het ondergrondbewerkingsproefveld op kavel C 62 in 1953.

\begin{tabular}{|c|c|c|c|c|c|}
\hline \multicolumn{2}{|c|}{$\begin{array}{cc}\text { Grondbewerking: } & 1952 \\
, & 1953\end{array}$} & \multirow[t]{2}{*}{$\begin{array}{l}20 \mathrm{~cm} \\
20 \mathrm{~cm}\end{array}$} & \multirow[t]{2}{*}{$\begin{array}{c}20 \mathrm{~cm} \\
\text { Neptunus }\end{array}$} & \multirow[t]{2}{*}{$\begin{array}{r}25+35 \mathrm{~cm} \\
\text { Neptunus }\end{array}$} & \multirow[t]{2}{*}{$\begin{array}{c}25+35 \mathrm{~cm} \\
20 \mathrm{~cm}\end{array}$} \\
\hline \multirow[t]{2}{*}{ Gewas } & $\mathrm{Kas}(\mathrm{kg} / \mathrm{ha})$ & & & & \\
\hline & & \multicolumn{4}{|c|}{ a. Opbrengst korrels of bieten } \\
\hline Haver & 300 & 42.9 & 43.1 & 42.2 & 41.9 \\
\hline Zomertarwe & 500 & 43.5 & 43.4 & 43.1 & 43.0 \\
\hline Zomergerst & 350 & 43.7 & 43.0 & 43.6 & 44.4 \\
\hline $\begin{array}{l}\text { Vlas } \\
\text { (Percello) }\end{array}$ & 150 & - & - & - & - \\
\hline \multirow{3}{*}{$\begin{array}{l}\text { Groene erwten } \\
\text { Suikerbieten } \\
\text { (Klein } \\
\text { Wanzleben E) }\end{array}$} & & 39.5 & 40.2 & 40.2 & 39.6 \\
\hline & 800 & 528 & 559 & 564 & 548 \\
\hline & & \multicolumn{4}{|c|}{ b. Opbrengst stro of bietekoppen } \\
\hline Haver & & 41.9 & 43.0 & 41.3 & 43.0 \\
\hline Zomertarwe & & 57.3 & 57.0 & 56.3 & 59.0 \\
\hline Zomergerst & & 45.1 & 46.1 & 43.3 & 44.3 \\
\hline $\begin{array}{l}\text { Vlas } \\
\text { (Percello) }\end{array}$ & & 84.2 & $\begin{array}{l}83.4 \\
\end{array}$ & $\begin{array}{l}43.3 \\
83.9\end{array}$ & 83.1 \\
\hline Groene erwten & & - & - & - & - \\
\hline $\begin{array}{l}\text { Suikerbieten } \\
\text { (Klein } \\
\text { Wanzleben E) }\end{array}$ & & 335 & 336 & 351 & 366 \\
\hline
\end{tabular}


Van de gewassen werden dezelfde rassen verbouwd als in 1952, met uitzondering van die van vlas en suikerbieten.

Deze gemiddelden van twee bepalingen zijn voor alle objecten ongeveer gelijk. Geen van de grondbewerkingen geeft betere resultaten dan de andere.

De wortels van de verschillende gewassen bereikten op de normaal geploegde grond een diepte van $\pm 50 \mathrm{~cm}$. Onder de bouwvoor was de beworteling sporadisch.

In de losgemaakte ondergrond werd een diepte van $60 \mathrm{~cm}$ bereikt, waarbij de bewortelingsdichtheid bij toenemende diepte betrekkelijk regelmatig geringer werd.

$\mathrm{Na}$ het rooien werden de suikerbieten van elk veldje verdeeld in drie groepen, n.l. normale bieten, korte bieten zonder pen en sterk vertakte bieten. Telling van deze bieten gaf het volgende resultaat.

TABEL 29. De vorm van de suikerbieten (\%) op het ondergrondbewerkingsprocfveld op kavel C 62 in 1953.

\begin{tabular}{l|r|r|r|r}
\hline \begin{tabular}{l|l|} 
Grondbewerking 1952 \\
1953
\end{tabular} & $\begin{array}{r}20 \mathrm{~cm} \\
20 \mathrm{~cm}\end{array}$ & $\begin{array}{c}20 \mathrm{~cm} \\
\text { Neptunus }\end{array}$ & $\begin{array}{c}25+35 \mathrm{~cm} \\
\text { Neptunus }\end{array}$ & $\begin{array}{c}25+35 \mathrm{~cm} \\
20 \mathrm{~cm}\end{array}$ \\
\hline Bietvorm: & & & & \\
$\quad$ Normaal & 22 & 48 & 60 & 51 \\
Kort & 71 & 45 & 32 & 42 \\
$\quad$ Vertakt & 7 & 7 & 8 & 7 \\
Aantal & 3181 & 3118 & 3083 & 3159 \\
\hline
\end{tabular}

Het aandeel van de normale bieten wordt groter door de ondergrondbewerking. Het aandeel sterk vertakte bieten is onafhankelijk van de ondergrondbewerking.

3. In de herfst van 1953 werd telkens een van de twee akkers die eenzelfde gewas hadden, op $\pm 20 \mathrm{~cm}$ diepte geploegd. Na de natte winter, toen het land voldoende was opgedroogd, werden in de tweede helft van maart 1954 de overgebleven akkers $\pm 10 \mathrm{~cm}$ diep geploegd.

Het proefveld was voor de twee voorafgaande gewassen steeds in het voorjaar geploegd, waardoor in een losse, onbezakte bouwvoor moest worden gezaaid. De bedoeling voor 1954 was het verkrijgen van een bezakte, normaal geploegde bouwvoor en een verse, ondiep geploegde bouwvoor. De lichte zavel van dit proefveld liet dit ploegen in het voorjaar uiteraard wel toe. Gedurende de winter en het voorjaar waren de vakken zonder ondergrondbewerking zeer nat, soms stond er water op het land. De vakken welke met de Neptunus waren losgemaakt, zonder voorafgaande ondergrondbewerking met de Mc. Cormickploeg met woelers, waren het droogst. 
Op het proefveld werden dezelfde gewassen als in de voorgaande jaren verbouwd.

Ten einde te kunnen nagaan, of de ondergrondbewerkingen en de verschillende behandelingen van de bouwvoor invloed hadden op de vruchtbaarheidstoestand van de bouwvoor, werden op de gewassen wintertarwe, haver en vlas op de beide akkers en alle ondergrondbewerkingsvakken proeven aangelegd met opklimmende hoeveelheden stikstof.

Het was namelijk gebleken, dat een ondergrondbewerking een hogere opbrengst tot gevolg kan hebben. Daar deze hogere opbrengsten ook met een grotere stikstofbemesting verkregen kunnen worden, bestaat de mogelijkheid, dat indien een stikstofgift wordt gegeven die de maximale opbrengst tot gevolg heeft, een verdere stijging van de vruchtbaarheid een oogstvermindering veroorzaakt. Met andere woorden, het is zeer moeilijk om voor proefvelden die om de een of ándere reden een verschillend vruchtbaarheidsniveau hebben, de juiste stikstofbemesting vast te stellen. Ook zonder deze verschillen is het bepalen (schatten) van de vermoedelijk beste stikstofbemesting reeds een grote moeilijkheid.

De vruchtopvolging en bemesting voor 1954 waren als volgt:

TABEL 30. Vruchtopvolging en stikstofbemesting op het ondergrondbewerkingsproefveld op kavel C 62 in 1954.

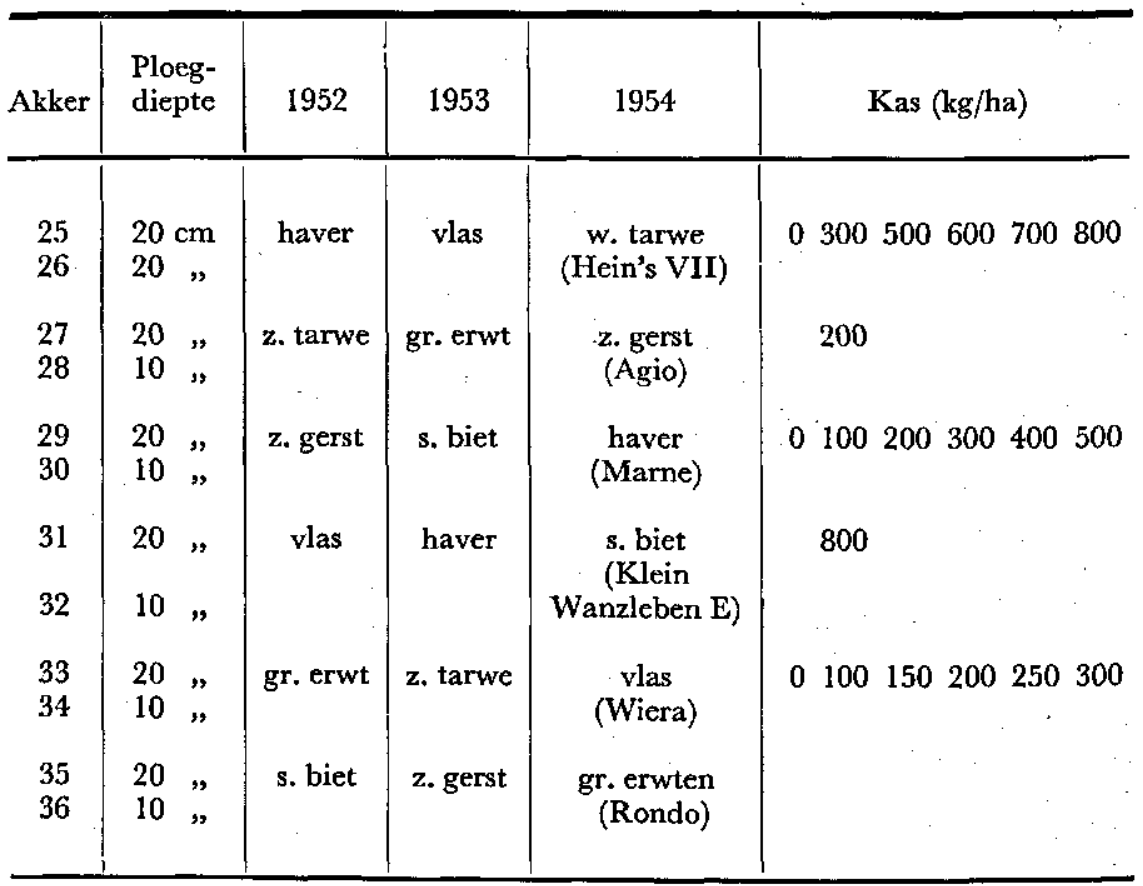


Begin april werd de grond zaaiklaar gemaakt, hetgeen wegens de voorafgaande regenperiode met betrekkelijk zware werktuigen moest gebeuren. De in de herfst geploegde akkers werden met een cultivator losgemaakt, de andere met een zware zig-zag eg bewerkt.

Gedurende de groei werd geen invloed van de ondergrondbewerking gezien. Op de ondiep geploegde akkers stonden haver en vlas tijdelijk beter dan op de normaal gẹploegde akkers. De zomergerst stond op de normaal geploegde akkers tijdelijk beter.

Eind juni, na een zware regenbui, bleek dat het vlas op de ondiep geploegde akkers iets meer legerde dan op de normaal geploegde akkers. Dit gold voor alle stikstofhoeveelheden. De onbemeste veldjes waren bovendien op de vakken die in het voorjaar 1952 waren geondergrond en daarna in 1953 en 1954 alleen geploegd, zwaarder dan op de vakken die ook nog met de Neptunus waren bewerkt of geen ondergrondbewerking hadden ondergaan.

Omstreeks midden augustus bleek, dat de haver op de ondiep geploegde akkers minder legerde dan op de normaal geploegde akkers. Invloed van de ondergrondbewerking werd niet opgemerkt.

De suikerbieten hadden zozeer van een luisaantasting geleden, dat opbrengstbepalingen niet verantwoord leken.

TABEL 31. Gemiddelde opbrengsten van de wintertarwe op het ondergrondbewerkingsproefveld op kavel C 62 bij opklimmende hoeveelheden stikstofmeststof in 1954.

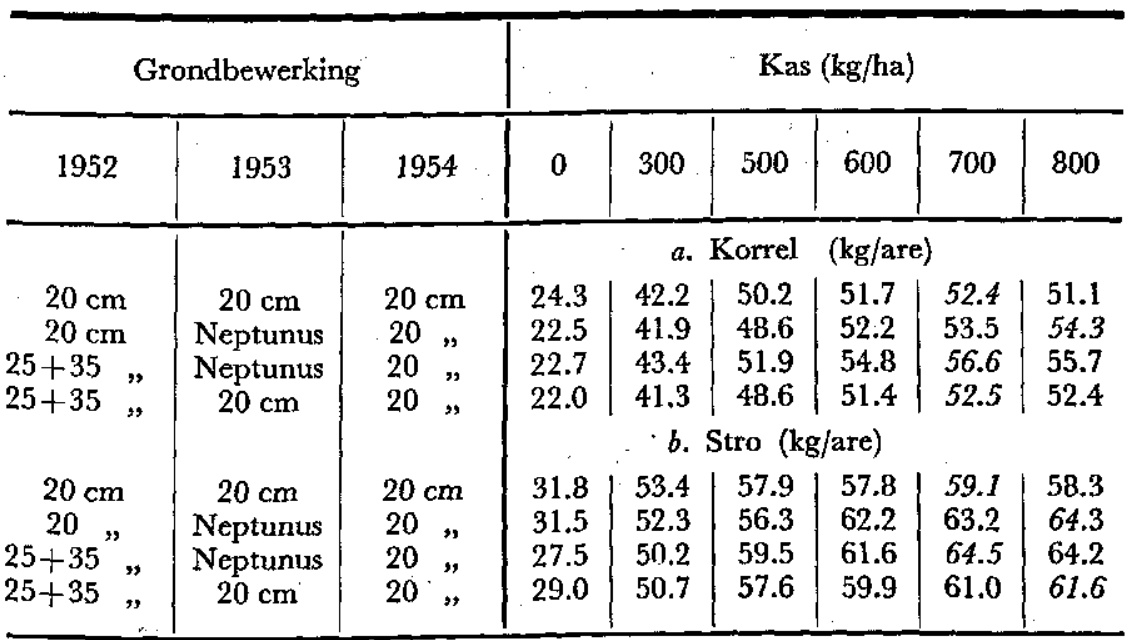

Deze opbrengsten zijn gemiddelden van vier waarnemingen. De laagste opbrengsten werden verkregen zonder ondergrondbewerking, de hoogste bij de gecombineerde ondergrondbewerking. 
TABEL 32. Gemiddelde opbrengsten (kg/are) van het ongerepelde vlas op het onder. grondbewerkingsproefveld op kavel C 62 in 1954.

\begin{tabular}{|c|c|c|c|c|c|c|c|c|}
\hline \multicolumn{3}{|c|}{ Grondbewerking } & \multicolumn{6}{|c|}{$\mathrm{Kas}(\mathrm{kg} / \mathrm{ha})$} \\
\hline 1952 & 1953 & 1954 & 0 & 100 & 150 & 200 & 250 & 300 \\
\hline $\begin{array}{c}20 \mathrm{~cm} \\
20 \mathrm{~cm} \\
25+35 \mathrm{~cm} \\
25+35 \mathrm{~cm}\end{array}$ & $\begin{array}{c}20 \mathrm{~cm} \\
\text { Neptunus } \\
\text { Neptunus } \\
20 \mathrm{~cm}\end{array}$ & $\begin{array}{l}20 \mathrm{~cm} \\
20 " \\
20 " \\
20 "\end{array}$ & $\begin{array}{l}64.6 \\
58.6 \\
58.5 \\
64.6\end{array}$ & $\begin{array}{l}78.9 \\
74.5 \\
73.4 \\
75.6\end{array}$ & $\begin{array}{l}82.7 \\
77.7 \\
82.2 \\
80.9\end{array}$ & $\begin{array}{l}87.0 \\
85.6 \\
84.6 \\
85.4\end{array}$ & $\begin{array}{l}88.3 \\
88.7 \\
85.7 \\
87.5\end{array}$ & $\begin{array}{l}90.3 \\
91.2 \\
86.2 \\
89.2\end{array}$ \\
\hline \multicolumn{3}{|c|}{ Gemiddelde gehele akker } & 61.6 & 75.6 & 80.9 & 85.7 & 87.6 & 89.2 \\
\hline $\begin{array}{c}20 \mathrm{~cm} \\
20 \mathrm{~cm} \\
25+35 \mathrm{~cm} \\
25+35 \mathrm{~cm}\end{array}$ & $\begin{array}{c}20 \mathrm{~cm} \\
\text { Neptunus } \\
\text { Neptunus } \\
20 \mathrm{~cm}\end{array}$ & $\begin{array}{l}10 \mathrm{~cm} \\
10 " \\
10 " \\
10 "\end{array}$ & $\begin{array}{l}63.2 \\
56.5 \\
60.4 \\
67.7\end{array}$ & $\begin{array}{l}76.2 \\
74.0 \\
72.8 \\
77.8\end{array}$ & $\begin{array}{l}81.0 \\
77.4 \\
81.0 \\
81.8\end{array}$ & $\begin{array}{l}86.2 \\
83.4 \\
83.5 \\
87.8\end{array}$ & $\begin{array}{l}85.6 \\
89.0 \\
84.7 \\
87.4\end{array}$ & $\begin{array}{l}87.3 \\
88.9 \\
85.7 \\
89.0\end{array}$ \\
\hline \multicolumn{3}{|c|}{ Gemiddelde gehele akker } & 65.9 & 75.2 & 80.3 & 85.2 & 86.7 & 87.7 \\
\hline
\end{tabular}

Uit deze gemiddelden van bepalingen in tweevoud blijkt, dat de bewerking met de Neptunus de opbrengst niet gunstig heeft beïnvloed. $\mathrm{Er}$ is geen verschil als gevolg van de ploegdiepte.

TABEL 33. Gemiddelde opbrengsten (kg/are) van de haver op het ondergrondbewerkingsproefveld op kavel C 62 in 1954.

\begin{tabular}{|c|c|c|c|c|c|c|c|c|}
\hline \multicolumn{3}{|c|}{ Grondbewerking } & \multicolumn{6}{|c|}{$\mathrm{Kas}(\mathrm{kg} / \mathrm{ha})$} \\
\hline \multirow[t]{2}{*}{1952} & 1953 & 1954 & 0 & 100 & 200 & 300 & 400 & 500 \\
\hline & & & \multicolumn{6}{|c|}{ a. Korrel } \\
\hline $20 \mathrm{~cm}$ & $20 \mathrm{~cm}$ & $20 \mathrm{en} 10 \mathrm{~cm}$ & 34.7 & 42.7 & 46.4 & 50.5 & 52.4 & 53.7 \\
\hline $20 \mathrm{~cm}$ & Neptunus & $"$ & 35.9 & 42.8 & 47.4 & 51.3 & 53.8 & 54.9 \\
\hline $25+35 \mathrm{~cm}$ & Neptunus & " & 35.3 & 41.7 & 47.4 & 53.3 & 53.8 & 54.1 \\
\hline \multirow{2}{*}{$25+35 \mathrm{~cm}$} & $20 \mathrm{~cm}$ & $"$ & 37.3 & 45.2 & 49.2 & 52.8 & 54.4 & 53.9 \\
\hline & & & \multicolumn{6}{|c|}{ b. Stro } \\
\hline $20 \mathrm{~cm}$ & $20 \mathrm{~cm}$ & , & 35.5 & 43.4 & 49.1 & 53.0 & 57.0 & 59.4 \\
\hline $20 \mathrm{~cm}$ & Neptunus & ", & 36.4 & 45.5 & 50.1 & 54.9 & 59.2 & 62.5 \\
\hline $25+35 \mathrm{~cm}$ & Neptunis & ”, & 35.9 & 43.6 & 50.4 & 57.3 & 58.8 & 61.1 \\
\hline $25+35 \mathrm{~cm}$ & $20 \mathrm{~cm}$ & $"$ & 38.6 & 47.5 & 53.5 & 57.3 & 60.1 & 63.2 \\
\hline
\end{tabular}


De opbrengsten van de vakken zonder ondergrondbewerking zijn het laagst. De ondergrondbewerking door middel van een ploeg met woelers geeft de hoogste opbrengst.

Er was geen verschil ten gevolge van het verschillend diep ploegen der akkers, zodat de gegevens het gemiddelde vormen van een viervoud.

TABEL 34. Gemiddelde opbrengsten (kg/are) van zomergerst en groene erwt op het ondergrondbewerkingsproefveld op kavel C 62 in 1954.

\begin{tabular}{|c|c|c|c|c|c|c|c|c|}
\hline $\begin{array}{cr}\text { Grond bewerking } 1952 \\
\Rightarrow & 1953 \\
" & 1954\end{array}$ & $\begin{array}{l}20 \mathrm{~cm} \\
20 \mathrm{~cm} \\
20 \mathrm{~cm}\end{array}$ & $\begin{array}{l}20 \mathrm{~cm} \\
\text { Nept. } \\
20 \mathrm{~cm}\end{array}$ & $\begin{array}{l}25+35 \\
\text { Nept. } \\
20 \mathrm{~cm}\end{array}$ & $\begin{array}{l}25+35 \\
20 \mathrm{~cm} \\
20 \mathrm{~cm}\end{array}$ & $\begin{array}{l}20 \mathrm{~cm} \\
20 \mathrm{~cm} \\
10 \mathrm{~cm}\end{array}$ & $\begin{array}{l}20 \mathrm{~cm} \\
\text { Nept. } \\
10 \mathrm{~cm}\end{array}$ & $\left|\begin{array}{c}25+35 \\
\text { Nept. } \\
10 \mathrm{~cm}\end{array}\right|$ & $\begin{array}{l}25+35 \\
20 \mathrm{~cm} \\
10 \mathrm{~cm}\end{array}$ \\
\hline $\begin{array}{cl}\text { Zomergerst } & \text { korrel } \\
\text {, } & \text { stro } \\
\text { Groene erwt korrel } \\
, y \quad, \ldots \text { stro }\end{array}$ & $\begin{array}{l}42.7 \\
44.1 \\
42.9 \\
52.7\end{array}$ & $\begin{array}{l}37.7 \\
38.3 \\
39.3 \\
48.5\end{array}$ & $\begin{array}{l}38.6 \\
39.8 \\
44.9 \\
52.1\end{array}$ & $\begin{array}{l}41.9 \\
45.5 \\
45.4 \\
50.6\end{array}$ & $\begin{array}{l}41.0 \\
42.7 \\
40.7 \\
50.6\end{array}$ & $\begin{array}{l}37.7 \\
37.6 \\
40.0 \\
48.1\end{array}$ & $\begin{array}{l}39.0 \\
40.6 \\
41.6 \\
47.1\end{array}$ & $\begin{array}{l}42.2 \\
42.0 \\
41.7 \\
46.9\end{array}$ \\
\hline
\end{tabular}

Uit deze gemiddelden van twee bepalingen blijkt, dat bij de zomergerst de bewerking met de Neptunus niet gunstig is geweest. $\mathrm{Bij}$ de groene erwten zijn de verschillen tussen de ondergrondbewerking dubieus wegens te grote spreiding van de gegevens. Verschillen tussen $20 \mathrm{~cm}$ en $10 \mathrm{~cm}$ ploegen zijn er niet.

Einde mei werden beworteling en aëratie op de wintertarwe-akkers onderzocht. Deze waren als volgt:

I. Geen ondergrondbewerking: Aëratie tot $45 \mathrm{~cm}$ volledig, beneden $50 \mathrm{~cm}$ afwezig.

Beworteling tot $47 \mathrm{~cm}$.

II. Eenmaal bewerkt met de Neptunus: Aëratie tot $50 \mathrm{~cm}$ volledig, beneden $60 \mathrm{~cm}$ afwezig.

Beworteling tot $50 \mathrm{~cm}$, dichter dan in $\mathrm{I}$.

III. Beẉerking met ondergronders en Neptunus: Aëratie tot $50 \mathrm{~cm}$ volledig, beneden $60 \mathrm{~cm}$ afwezig.

Beworteling tot $62 \mathrm{~cm}$ en vrij dicht.

Náást de door de Neptunus losgemaakte gedeelten is de doorworteling geringer, de aëratie echter gelijk.

IV: Bewerking met ondergronders: Aëratie tot $38 \mathrm{~cm}$ volledig, beneden $60 \mathrm{~cm}$ afwezig.

Beworteling tot $50 \mathrm{~cm}$.

In 1955 werd de aëratie einde juli weer opgenomen: De grond was toen volledig geaëreerd tot $50 \mathrm{~cm}$, de ongeaëreerde grond begon op $60-70 \mathrm{~cm}$ diepte. 


\section{Samenvatting}

De over drie jaren lopende vrij intensieve proefnemingen op kavel C 62 hebben geen overtuigend bewijs geleverd, dat de ondergrondbewerking een hogere opbrengst tot gevolg heeft. Wel bleek geregeld, dat de aëratie en beworteling gunstig werden beïnvloed en dat in de winter de gedeelten zonder ondergrondbewerking een nattere bouwvoor hadden. De invloed op de aëratie en de beworteling waren echter betrekkelijk gering. Op kavel B 68 waren zij veel sprekender.

f. Het proefveld op kavel D 24

$$
\text { Profiel: } \begin{array}{rlll}
0-20 & \mathrm{~cm} & \text { bouwvoor } & \text { gr. } 4 \\
20-45 & & \text { Espelzand } & \text { gr. } 2 \mathrm{~d} \\
45-55 & & \text { Zus } & \text { gr. } 5 \\
55-60 & \Rightarrow \text { Sl. I b } & \text { gr. } 4 \\
>60 & \Rightarrow \text { Sl. II a-II b gr. } 2 \text { eb-4h }
\end{array}
$$

Het profiel bestaat dus uit een bouwvoor van lichte zavel, gescheiden van een iets zwaardere zavellaag door een dik pakket Espelzand. Deze zandlaag is dikker dan de overeenkomstige laag op de kavels B 68 en C. 62 .

De voorbereidingen voor de proefnemingen werden in de zomer van 1952 getroffen, nadat reeds ervaring was opgedaan op andere ondergrondbewerkingsproefvelden. Hierbij was naar voren gekomen:

1. De afmetingen van de vakken met verschillende ondergrondbewerkingen moeten zo groot zijn, dat een onderlinge beïnvloeding uitgesloten moet worden geacht, ook indien naderhand nog tot een onderverdeling mocht worden overgegaan.

Op kavel O 98 waren de stroken $\pm 50 \mathrm{~m}$ breed; op de kavels B 68 en $\mathrm{C} 62$ zouden $\mathrm{zij} \pm 30 \mathrm{~m}$ breed worden. Beïnvloeding werd verwacht ten gevolge van een mogelijke invloed op de grondwaterstand.

2. De ondergrondbewerking moet zo mogelijk in een droge grond gebeuren, omdat dan een betere brekende werking kan worden verwacht.

3. De omvang van het proefveld moet zo groot zijn, dat er voldoende ruimte is om behalve de verbouw van verschillende gewassen ook nog enige variatie in de bouwbewerking te kunnen toepassen, indien de toestand van de bouwvoor als gevolg van de ondergrondbewerking hiertoe aanleiding geeft.

4. Buiten de te oogsten proefveldjes moet voldoende ruimte overblijven om gedurende een aantal jaren de beworteling van de gewassen te onderzoeken. Kuilen in de te oogsten veldjes kunnen, ook indien zij na de ooggst worden gemaakt, de groei in een volgend jaar beinvloeden.

5. De plaats van het proefveld moet met zeer veel zorg worden bepaald ten einde de vergelijkbaarheid van de wel en niet losgemaakte ondergrond zo groot mogelijk te doen zijn. 
Op kavel D 24 (de akkers $41 \mathrm{t} / \mathrm{m}$ 54) werd een complex gevonden dat aan deze voorwaarden voldeed. Achteraf bleek, dat de Espelzandlaag in de akkerrichting van west naar oost afnam van $\pm 30 \mathrm{~cm}$ dikte tot \pm 15 cm dikte. In het midden bedroeg de dikte $\pm 25 \mathrm{~cm}$. Dit betekent, dat het profiel enigszins beter wordt naarmate de zandlaag dunner is.

Op deze kavel werd onderzocht, tot welke diepte een dergelijk profiel moet worden losgemaakt, indien wordt aangenomen dat de lichte zavellaag op $\pm 50 \mathrm{~cm}$ diepte voldoende snel rijpt en goed doorwortelbaar is, indien de bovenliggende zandlaag wordt losgemaakt.

Een dergelijk profiel kan dus tot $\pm 50 \mathrm{~cm}$ worden geondergrond met een ploeg met ondergronders, waarna de volgende $20 \mathrm{~cm}$,vanzelf" beter wordt. Het kan ook worden losgemaakt tot $70 \mathrm{~cm}$, waarbij de onderliggende sloef $\mathrm{I} b$ tevens wordt losgemaakt en bovendien misschien nog een gedeelte van de zandige sloef $2 \mathrm{e}^{\mathrm{h}}$.

1. De kavel werd in de lengterichting in drie stroken verdeeld.

In september 1952 werd de eerste strook na een droge periode met de Neptunus tot $\pm 70 \mathrm{~cm}$ diepte losgemaakt.

De derde strook werd in de laatste dagen van september op $20 \mathrm{~cm}$ diepte geploegd, hetgeen goed ging, ondanks het regenachtige weer.

Het ploegen van de tweede strook met de Mc. Cormickploeg met ondergronders moest worden uitgesteld tot het enige dagen droog was geweest. De rupstrekker makte te diepe sporen in het natte land.

Het op $20 \mathrm{~cm}$ diepte ploegen van de eerste strook ging zeer goed, omdat de grond los en droog was. Wel had de ploeg enige neiging om dieper weg te zakken dan voor $20 \mathrm{~cm}$ ploegen nodig was.

$\mathrm{Na}$ het ploegen werd op de akkers 53 en 54 Alba wintertarwe gezaaid. Op de derde strook waren gewichten aan de zaaipijpen nodig, op de eerste en tweede strook sleepvoetjes.

Gedurende de winter 1952-1953 werd door middel van grondwaterstandsbuizen het grondwaterpeil op de drie stroken opgenomen.

Dit gebeurde eveneens op de proefvelden op de kavels B 68 en C 62 .

Enkele gegevens van de natste perioden volgen hier, omdat gedurende deze dagen de verschillen het grootst waren. (Tabel 35)

Gedurende de drogere periode was de grondwaterstand in de diep losgemaakte stroken $5-10 \mathrm{~cm}$ lager dan in de niet losgemaakte stroken. Uit deze cijfers blijkt, dat de sterke fluctuaties van de grondwaterstand door de ondergrondbewerking verdwijnen, met het gevolg dat de grondwaterstand niet meer tot aan of in de bouwvoor komt.

De resultaten van deze verschillen in ontwateringstoestand bleken uit de structuur en het vochtgehalte van de bouwvoor in het voorjaar. Op kavel D 24 was de bouwvoor van de derde strook in het voorjaar geheel verslempt en stijf. De wel losgemaakte ondergrond had een luchtige, betrekkelijk droge bouwvoor.

De A-cijfers (vochtgehalte ten opzichte van droge grond) van de laag $0-5 \mathrm{~cm}$ waren op 10 maart 1953 voor de eerste, tweede en derde strook respectievelijk $16.4,19.3$ en 24.2 . 
TABEL 35. Grondwaterstand (in $\mathrm{cm}$ beneden maaiveld) op de ondergrondbewerkingsproefvelden op de kavels B 68, C 62 en D 24 gedurende de winter $1952-1953$.

\begin{tabular}{l|c|c|c|c|c|c|c|c|c}
\hline \multirow{2}{*}{ Kavel } & Bewerkings- & \multicolumn{7}{|c|}{ Datum } \\
\cline { 3 - 9 } & diepte & $7-11$ & $20-11$ & $6-12$ & $17-12$ & $22-12$ & $2-2$ & $11-2$ & $18-2$ \\
\hline B 68 & $20 \mathrm{~cm}$ & 30 & 48 & 52 & 17 & 33 & 44 & 17 & 22 \\
& $50 "$ & 50 & 64 & 74 & 43 & 56 & 62 & 45 & 55 \\
& $70 "$ & 60 & 67 & 86 & 65 & 60 & 64 & 60 & 70 \\
\hline C 62 & $20 \mathrm{~cm}$ & 12 & 27 & 52 & 0 & 4 & 13 & 10 & 21 \\
& $50 "$ & 44 & 53 & 64 & 40 & 44 & 47 & 42 & 47 \\
\hline D 24 & $20 \mathrm{~cm}$ & 18 & 32 & 51 & 11 & 28 & 24 & 13 & 17 \\
& $50 "$ & 31 & 49 & 63 & 22 & 30 & 42 & 23 & 27 \\
& $70 "$ & 48 & 65 & 69 & 45 & 50 & 51 & 50 & 49 \\
\hline
\end{tabular}

De structuurverschillen van de bouwvoor waren op dit proefveld zo groot, dat de eerste en tweede strook eind februari reeds zonder veel bewerking zaaiklaar konden worden gemaakt, terwijl de derde strook in de tweede helft van maart pas in een redelijk bewerkbare toestand kwam. Van deze omstandigheid werd gebruik gemaakt om de invloed van verschillende manieren van zaaiklaar maken van de grond na te gaan. Voor de losse grond zou een lichte oppervlakkige bewerking voldoende zijn, terwijl de natte, stijve grond een intensieve bewerking zou moeten hebben. Daarom werden op twee naast elkaar liggende akkers, of twee akkerhelften, zware en lichte zaaibedbewerkingen toegepast, waarna een gewas werd ingezaaid. Voor haver en suikerbieten werden op drie tijdstippen verschillende stroken klaargemaakt, ten einde de vroegere inzaaimogelijkheid op de geondergronde stroken te benutten en een eventueel nadeel van de latere inzaai van de niet geondergronde stroken te laten blijken.

Haver werd gezaaid op 28 februari en 10 en 20 maart. Voor de losse grond op de eerste en tweede strook werd op deze data het gebruik van een zware zig-zag eg voldoende geacht. Waarschijnlijk was een lichtere eg ook geschikt geweest. Voor de verslempte derde strook werden op deze data respectievelijk een cultivator met brede ganzevoeten, een lichte scharniereg en de zware zig-zag eg nodig geoordeeld.

Hieruit blijkt, dat het verschil in bewerkbaarheid zeer groot was en dat de verslempte grond langzamerhand beter werd. De zware zig-zag eg trok op de stijve grond slechts strepen, zodat van zaaiklaar maken niet kon worden gesproken. $\mathrm{Bij}$ het zaaien moesten de zaaipijpen worden ver- 
zwaard met gewichten om het zaad voldoende bedekt te krijgen. Op de twee andere stroken waren sleepvoetjes nodig om te diep zaaien te voorkomen.

De haver kwam achtereenvolgens op 2 april, 2 april en 10 april boven de grond. Opvallende groeiverschillen kwamen alleen voor op de derde strook, op akker $41 \mathrm{z}$ (uid) en akker $42 \mathrm{z}$ (uid). Op deze betrekkelijk diep bewerkte, verslempte bouwvoor bleef het gewas korter en had het een wat gelere tint. De oogstdepressie die hiervan het gevolg was, kwam het sterkst tot uiting op een van de twee veldjes die op deze strook lagen, en wel op dat veldje, dat het dichtst bij de kopakkers was gelegen. Dit is het veldje in de derde strook onder nummer 6 in tabel 36. Deze strook had op het gehele proefveld een lagere opbrengst.

Ook bij de groene erwten kwam de minder gunstige werking van het diepe losmaken met de cultivator tot uiting. Er is dus een aanwijzing, dat een zware bewerking van deze lichte grond in natte toestand niet altijd gewenst is, ook al lijkt het nodig om een goed zaaibed te verkrijgen.

Voor groene erwten, vlas en suikerbieten werd het zaaibed ook op verschillende manieren klaargemaakt. De cultivator en de zware zig-zag eg werden vergeleken bij de groene erwten en de suikerbieten, eveneens met een ongunstig resultaat voor de cultivator.

Het vlasland werd gedeeltelijk voorgerold en gedeeltelijk gesleept. Op het gerolde gedeelte kwam het vlas enkele dagen vroeger op dan op het gesleepte gedeelte. Deze voorsprong bleef gedurende de groeiperiode behouden. De latere opkomst op het gesleepte gedeelte kan zijn veroorzakkt door droogte, al dan niet gecombineerd met te diep zaaien.

Op de wintertarwe werd op de drie stroken een proef gelegd met opklimmende hoeveelheden stikstofmeststof.

In tabel 36 staan de opbrengsten van de gewassen. Op elke strook werd de opbrengst in tweevoud bepaald. De opbrengst van de wintertarwe is het gemiddelde van de in viervoud bepaalde opbrengst van één van de stikstofbemestingen. Ras en bemesting van de gewassen zijn in de tabel vermeld.

Alle gewassen reageerden gunstig op de ondergrondbewerking met de Neptunus. De onbewerkte ondergrond gaf lagere opbrengsten.

De invloed van de zaaitijd op de haveropbrengsten is gering gebleken, mogelijk door het geringe verschil in opkomst.

Sprekender is de hogere opbrengst op de stroken met losgemaakte ondergrond.

De zomertarwe reageerde er niet op, de zomergerst wel.

De groene erwten en het vlas reageerden weinig op de ondergrondbewerking, maar des te duidelijker op de bewerking voor het zaaien.

Hoewel uit de opbrengsten van de wintertarwe bij $600 \mathrm{~kg}$ kas per ha reeds blijkt, dat dit gewas ook gunstig reageert op de ondergrondbewerking, wordt deze invloed nog veel duidelijker bij beschouwing van de volledige gegevens. (Tabel 37) 


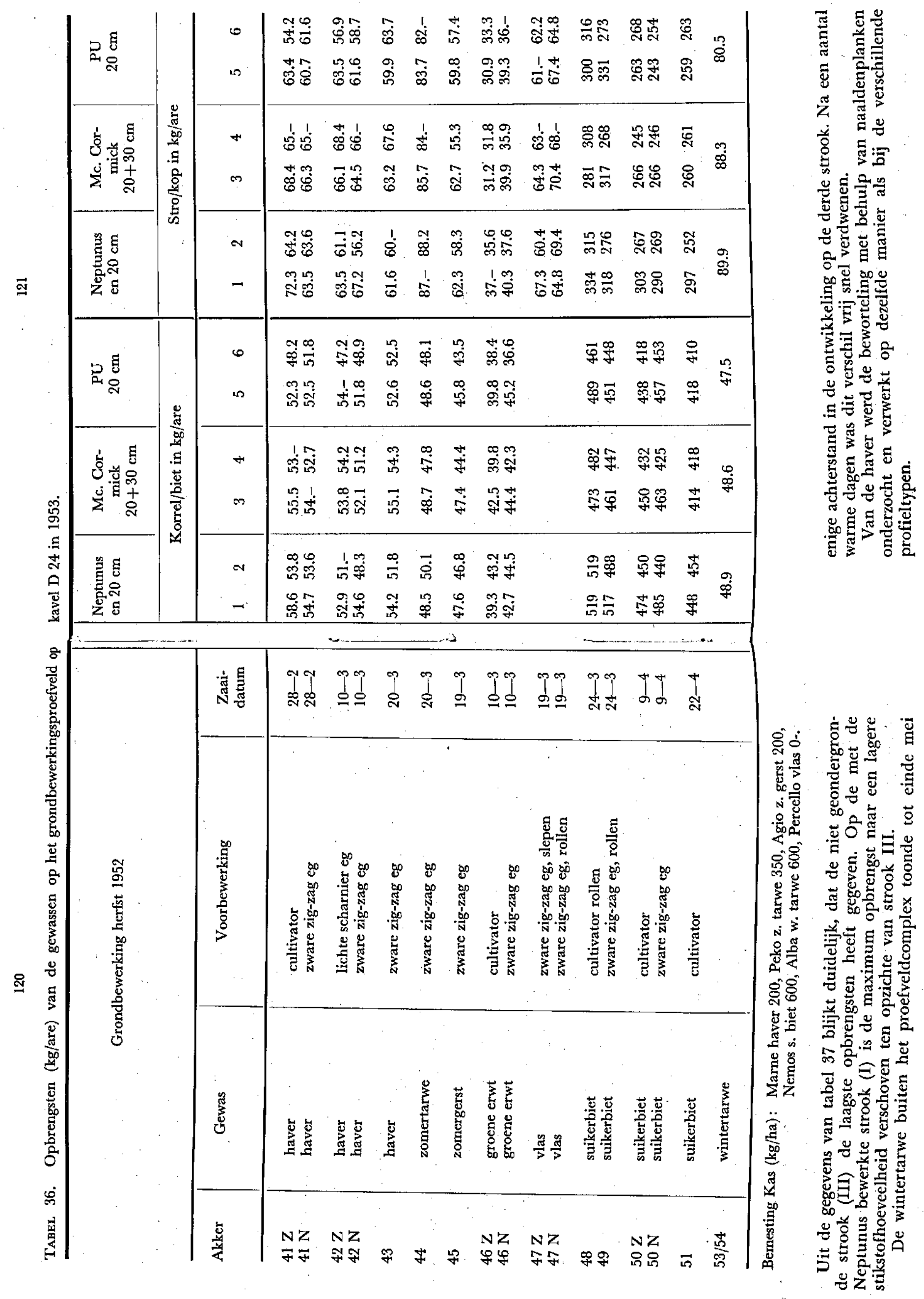


TABEL 37. Gemiddelde opbrengsten ( $\mathrm{kg} / \mathrm{are}$ ) van de wintertarwe op het ondergrondbewerkingsproefveld op kavel D 24 bij verschillende stikstofbemestingen.

I Ondergrond gebroken tot $70 \mathrm{~cm}$ met de „Neptunus” en $20 \mathrm{~cm}$ ploegen.

II Ondergrond gebroken tot $50 \mathrm{~cm}$ en tegelijkertijd geploegd tot $20 \mathrm{~cm}$.

III Geploegd op $20 \mathrm{~cm}$.

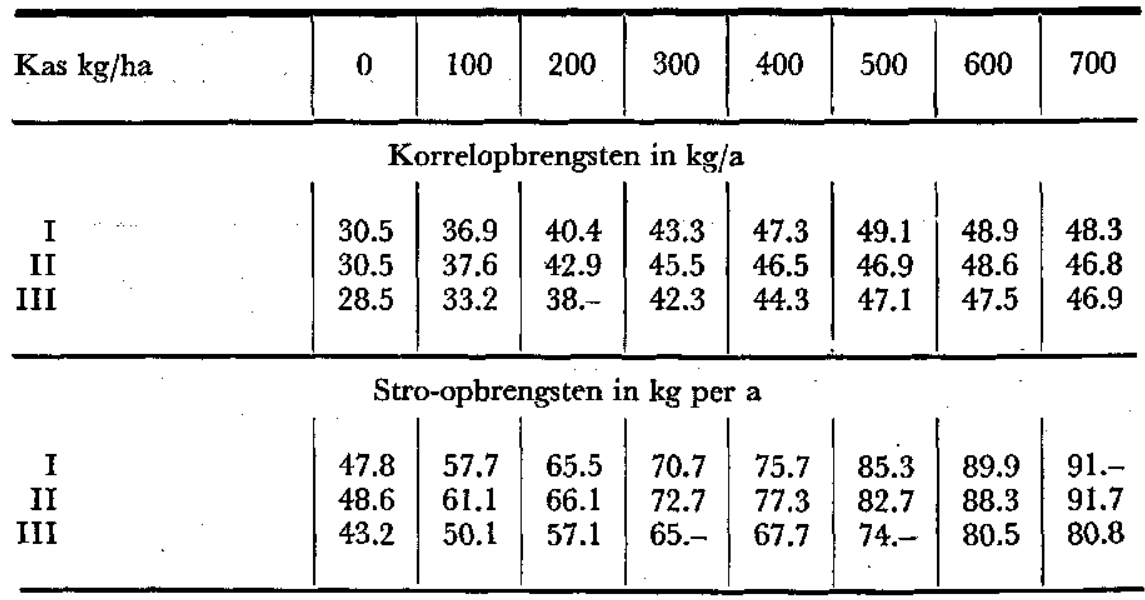

Van de wintertarwe werd de beworteling onderzocht met behulp van een grondboor, waarbij van elk veldje, op een plaats tegen de wintertarwe-rij aan, de laag van $0-70 \mathrm{~cm}$ werd bemonsterd in lagen van $10 \mathrm{~cm}$ dikte. De bedoeling was hierbij om behalve de invloed van de ondergrondbewerking ook die van de stikstofbemesting op de wortelhoeveelheid te onderzoeken.

TABeL 38. De verdeling (\%) van de wortels van haver en wintertarwe in de laag $20-70 \mathrm{~cm}$ van het ondergrondbewerkingsproefveld op kavel D 24 in 1953.

\begin{tabular}{c|c|c|c|c|c|c}
\hline & \multicolumn{3}{|c|}{ Haver } & \multicolumn{3}{|c}{ Wintertarwe } \\
\hline Strook: & I & II & III & I & II & III \\
& $(70 \mathrm{~cm})$ & $(50 \mathrm{~cm})$ & $(20 \mathrm{~cm})$ & $(70 \mathrm{~cm})$ & $(50 \mathrm{~cm})$ & $(20 \mathrm{~cm})$ \\
\hline & & & & & & \\
\hline $20-30 \mathrm{~cm}$ & 36 & 41 & 59 & 31 & 36 & 34 \\
$30-40 \%$ & 18 & 20 & 25 & 18 & 17 & 25 \\
$40-50 "$ & 19 & 22 & 11 & 18 & 24 & 27 \\
$50-60 "$, & 19 & 13 & 2 & 19 & 17 & 14 \\
$60-70 \%$ & 7 & 4 & 3 & 14 & 6 & 0 \\
$20-70 \%$ & $1106 \mathrm{mg}$ & $692 \mathrm{mg}$ & $498 \mathrm{mg}$ & $2375 \mathrm{mg}$ & $2850 \mathrm{mg}$ & $1340 \mathrm{mg}$ \\
\hline
\end{tabular}


De suikerbieten werden op de reeds eerder beschreven manier in drie groepen ingedeeld, waarbij het totale aantal en de verdeling werden bepaald.

De tabellen 38 en 39 geven een overzicht van dit bewortelingsonderzoek.

De haver en de wintertarwe volgen met de verdeling van de wortels de ondergrondbewerking behoorlijk goed. De hoeveelheid wortels (ook hier berekend voor een blok van $10 \times 23 \times 50 \mathrm{~cm}^{3}$ ) is in het niet losgemaakte profiel het laagst.

TABEL 39. De verdeling der bieten in verschillende vormen in procenten op het ondergrondbewerkingsproefveld op kavel D 24 in 1953.

\begin{tabular}{|c|c|c|c|c|c|c|c|c|c|}
\hline Strook: & \multicolumn{3}{|c|}{$\mathrm{I}(70 \mathrm{~cm})$} & \multicolumn{3}{|c|}{ II $(50 \mathrm{~cm})$} & \multicolumn{3}{|c|}{ III $(20 \mathrm{~cm})$} \\
\hline Vorm: & $n^{1}$ & $\mathrm{k}^{1}$ & $t^{1}$ & $\mathbf{n}$ & $\mathbf{k}$ & $\mathbf{t}$ & $\mathbf{n}$ & $\mathbf{k}$ & $\mathbf{t}$ \\
\hline \begin{tabular}{lll}
\multicolumn{3}{l}{ Voorbewerking } \\
a & 48 cultivator \\
a & 49 & zig-zag eg \\
a & $\left.50 z^{4}\right)$ & cultv. \\
a & $\left.50 n^{4}\right)$ & zig-zag eg \\
a & 51 & cultivator
\end{tabular} & $\begin{array}{l}59 \\
63 \\
54 \\
64 \\
54\end{array}$ & $\begin{array}{l}38 \\
31 \\
36 \\
28 \\
39\end{array}$ & $\begin{array}{r}3\left(1359^{3}\right) \\
6(1270) \\
10(868) \\
8(821) \\
7(1876)\end{array}$ & $\begin{array}{l}63 \\
57 \\
59 \\
56 \\
62\end{array}$ & $\begin{array}{l}31 \\
32 \\
34 \\
39 \\
30\end{array}$ & $\begin{array}{r}6(1289) \\
11(1180) \\
7(865) \\
5(846) \\
8(1702)\end{array}$ & $\begin{array}{l}28 \\
38 \\
34 \\
34 \\
59\end{array}$ & $\begin{array}{l}65 \\
55 \\
56 \\
56 \\
37\end{array}$ & $\begin{array}{r}7(1221) \\
7(1306) \\
10(824) \\
10(868) \\
4(1746)\end{array}$ \\
\hline
\end{tabular}

1) Zie noot 1 bij tabel 17 .

2) $\mathrm{a}=$ akker

3) = het aantal getelde bieten

4) $\mathrm{n}=$ noord $\mathrm{z}=$ zuid.

De verbetering van het model is onmiskenbaar. Op akker 51 is bij de late zaai de vorm van de bieten ook op de niet geondergronde strook goed geworden.

Een onderzoek naar aëratie en beworteling onder wintertarwe leverde het volgende op.

\begin{tabular}{|c|c|c|c|c|c|c|c|c|c|}
\hline & \multicolumn{3}{|c|}{19 maart } & \multicolumn{3}{|c|}{8 mei } & \multicolumn{3}{|c|}{ II juni } \\
\hline Strook: & I & II & III & I & II & III & I & II & III \\
\hline $\begin{array}{l}\text { Geheel geaëreerd tot } \\
\text { Ongeaëreerd beneden } \\
\text { Bewortelingsgrens }\end{array}$ & $\begin{array}{l}28 \mathrm{~cm} \\
76 \% \\
70 \%\end{array}$ & $\begin{array}{l}30 \mathrm{~cm} \\
55 ” \\
55 \%\end{array}$ & $\begin{array}{l}25 \mathrm{~cm} \\
48 \cdots \\
30 "\end{array}$ & $65 \mathrm{~cm}$ & $53 \mathrm{~cm}$ & $\begin{array}{l}28 \mathrm{~cm} \\
47 " \\
47 "\end{array}$ & $75 \mathrm{~cm}$ & $75 \mathrm{~cm}$ & $65 \mathrm{~cm}$ \\
\hline
\end{tabular}

Zomergerst en zomertarwe hadden op 11 juni een zelfde diepte bereikt als de wintertarwe. De wortels van vlas bereikten in de vakken I, II en III respectievelijk een diepte van 65,55 en $40 \mathrm{~cm}$ en die van groene erwten respectievelijk een diepte van 55,47 en $43 \mathrm{~cm}$. 
2. Voor het groeiseizoen 1953-1954 werd het proefveld op zeer uiteenlopende data geploegd. Begonnen werd op 8 oktober en geëindigd op 10 april daaraanvolgend. Het was de bedoeling op deze manier de invloed van het weer op de structuur van de bouwvoor na te gaan, bij verschillende ondergrondbewerkingen. Het najaar was echter betrekkelijk droog, zodat de regen welke in januari viel, op een betrekkelijk droge grond kwam. Na de vorstperiode in februari bleek de vorst op de geondergronde stroken tot $\pm 28 \mathrm{~cm}$ en in de niet geondergronde strook tot $\pm 49 \mathrm{~cm}$ te zijn ingedrongen. Deze derde strook is steeds natter geweest. Begin maart, na veel regen, stond er veel water op de niet geondergronde strook. De andere stroken hadden geen plassen, waren echter wel nat.

$\mathrm{Na}$ een droge periode in maart bleef de niet geondergronde strook achter met opdrogen. Er werd bij het zaaiklaar maken gebruik gemaakt van de cultivator en de lichte scharniereg. De hierdoor ontstane verschillen in structuur van de bouwvoor waren van tijdelijke aard, omdat daarna het gehele proefveld met de zware zig-zag eg werd bewerkt:

De verbouwde gewassen waren:

Wintertarwe (Heine's VII), na haver, met opklimmende hoeveelheden stikstofmeststof op een van de drie akkers.

Groene erwten (Rondo), na zomertarwe.

Vlas (Wiera), na zomergerst, met opklimmende hoeveelheden stikstofmeststof; als ondervrucht werd luzerne gezaaid.

Zomergerst (Agio), na groene erwten, met als ondervrucht luzerne; bemesting $200 \mathrm{~kg} / \mathrm{ha}$ kas.

Aardappelen (Voran), na vlas, bemesting $700 \mathrm{~kg} / \mathrm{ha}$ kas.

Zomertarwe (Peko), na suikerbieten, met opklimmende hoeveelheden stikstofmeststof; een van de beide akkers was met de cultivator, de andere met de zware zig-zag eg voorbewerkt.

Haver (Marne), na suikerbieten, met een zelfde bewerking van de bouwvoor als de zomertarwe; bemesting $200 \mathrm{~kg} /$ ha kas.

Suikerbieten (Klein Wanzleben E), na wintertarwe en bruine bonen (noodgewas 1953); bemesting $700 \mathrm{~kg} / \mathrm{ha}$ kas.

De ontwikkeling van deze gewassen is voortdurend op de geondergronde stroken iets beter geweest dan op de niet geondergronde strook. Dit kwam tot uiting in de iets zwaardere gewassen en een sterkere neiging tot legeren van de veldjes met de zwaarste stikstofbemesting op de geondergronde stroken.

De aardappelen en de suikerbieten konden ten gevolge van de grote 
afmetingen van de veldjes machinaal worden gerooid. Als trekkracht fungeerde een Fordson wieltrekker. Deze was niet in staat de werktuigen op de niet geondergronde stroken alleen te trekken, wegens optredende wielslip in de natte grond. Aanvullende trekkracht werd geleverd door

TABEL 40. Gemiddelde opbrengsten (kg/are) van wintertarwe, zomertarwe en vlas bij de proeven met opklimmende hoeveelheden stikstofmeststof op het grondbewerkingsproefveld op kavel D 24 in 1954.

\begin{tabular}{|c|c|c|c|c|c|c|c|c|c|}
\hline $\mathrm{Kas}(\mathrm{kg} / \mathrm{ha})$ : & & 0 & 200 & 300 & 400 & 500 & 600 & 700 & 800 \\
\hline $\begin{array}{l}\text { Wintertarwe } \\
\text { Korrel } \\
\text { Stro }\end{array}$ & $\begin{array}{l}\text { I') }^{\prime} \\
\left.\text { II' }^{\prime}\right) \\
\text { III') }^{\prime} \\
\text { I } \\
\text { II } \\
\text { III }\end{array}$ & $\begin{array}{l}27.9 \\
25.2 \\
24 .- \\
36.3 \\
34.9 \\
32 .-\end{array}$ & & $\begin{array}{l}44.6 \\
44.6 \\
42.7 \\
54.2 \\
54.9 \\
50.4\end{array}$ & $\begin{array}{l}46.1 \\
47.9 \\
45.8 \\
56.7 \\
59.9 \\
53.7\end{array}$ & $\begin{array}{l}49.7 \\
49.7 \\
48.1 \\
60.4 \\
60.8 \\
55.5\end{array}$ & $\begin{array}{l}51 .- \\
51.7 \\
48 .- \\
63.6 \\
63.5 \\
56.3\end{array}$ & $\begin{array}{l}47.8 \\
50.8 \\
48.8 \\
63.9 \\
63.4 \\
58.9\end{array}$ & $\begin{array}{l}49.9 \\
52.1 \\
49 .- \\
65.8 \\
64.7 \\
61.1\end{array}$ \\
\hline $\begin{array}{l}\text { Zomertarwe } \\
\text { Korrel }\end{array}$ & $\begin{array}{r}\text { I } \\
\text { II } \\
\text { III } \\
\text { I } \\
\text { II } \\
\text { III }\end{array}$ & $\begin{array}{l}35.5 \\
31 .- \\
31.6 \\
63.7 \\
62.5 \\
52.5\end{array}$ & $\begin{array}{l}43.5 \\
41.4 \\
41.2 \\
79.1 \\
73.7 \\
70.6\end{array}$ & $\begin{array}{l}44.6 \\
43.7 \\
43.2 \\
83.1 \\
83.2 \\
74.3\end{array}$ & $\begin{array}{l}45 .- \\
43.5 \\
43.9 \\
85.9 \\
84.3 \\
77.3\end{array}$ & $\begin{array}{l}43.3 \\
44.5 \\
42.0 \\
85.8 \\
86.9 \\
76.1\end{array}$ & $\begin{array}{l}42.2 \\
43.3 \\
42.2 \\
84.8 \\
84.7 \\
78.2\end{array}$ & $\begin{array}{l}41 .- \\
42.5 \\
42.3 \\
84.2 \\
84.2 \\
78.6\end{array}$ & \\
\hline $\mathrm{Kas}(\mathrm{kg} / \mathrm{ha})$ : & & 0 & 50 & 100 & 150 & 200 & 250 & 300 & \\
\hline Vlas ongerepeld & $\begin{array}{r}\text { I } \\
\text { II } \\
\text { III }\end{array}$ & $\begin{array}{l}82.1 \\
72.6 \\
75 .-\end{array}$ & $\begin{array}{l}84.2 \\
79.2 \\
78 .-\end{array}$ & $\begin{array}{l}89.1 \\
87.5 \\
82.7\end{array}$ & $\begin{array}{l}91.6 \\
91 .- \\
89.1\end{array}$ & $\begin{array}{l}93.1 \\
89.5 \\
90.2\end{array}$ & $\begin{array}{l}95.1 \\
92.6 \\
93.4\end{array}$ & $\begin{array}{l}96.6 \\
96.4 \\
97.5\end{array}$ & \\
\hline
\end{tabular}

TABEL 41. Gemiddelde opbrengsten (kg/are) van groene erwten, zomergerst, aardappelen, haver en suikerbieten op het ondergrondbewerkingsproefveld op kavel D 24 in 1954.

\begin{tabular}{|c|c|c|c|c|c|c|c|c|c|c|}
\hline & \multicolumn{2}{|c|}{$\begin{array}{c}\text { Groene } \\
\text { erwten }\end{array}$} & \multicolumn{2}{|c|}{$\begin{array}{c}\text { Zomer } \\
\text { gerst }\end{array}$} & \multicolumn{2}{|c|}{$\begin{array}{l}\text { Aard- } \\
\text { appelen }\end{array}$} & \multicolumn{2}{|c|}{ Haver } & \multicolumn{2}{|c|}{$\begin{array}{c}\text { Suiker- } \\
\text { bieten }\end{array}$} \\
\hline $\begin{array}{r}\left.I^{\prime}\right) \\
\left.I I^{\prime}\right) \\
\left.I I^{\prime}\right)\end{array}$ & $\begin{array}{l}\text { zaad } \\
42.6 \\
41.1 \\
39.5\end{array}$ & $\begin{array}{l}\text { stro } \\
43.7 \\
46.8 \\
42.5\end{array}$ & $\begin{array}{l}\text { zaad } \\
45.3 \\
46.3 \\
48.5\end{array}$ & $\begin{array}{l}\text { stro } \\
51.1 \\
52.5 \\
52.6\end{array}$ & $\begin{array}{c}\text { knol } \\
434 \\
430 \\
419\end{array}$ & $\left(\begin{array}{c}\left.\text { owg }^{2}\right) \\
416 \\
408 \\
392\end{array}\right.$ & $\begin{array}{c}\text { zaad } \\
55.2 \\
53.6 \\
51.8\end{array}$ & $\begin{array}{c}\text { stro } \\
- \\
- \\
-\end{array}$ & $\begin{array}{l}\text { biet } \\
570 \\
551 \\
575\end{array}$ & $\begin{array}{l}\text { loof } \\
308 \\
278 \\
263\end{array}$ \\
\hline
\end{tabular}

) zie tabel 37 .

2) o.w.g. = onder-water-gewicht. 
een span paarden bij de aardappelen en een tweede wieltrekker bij de suikerbieten. Op de geondergronde stroken spoorde de trekker niet in en konden de werktuigen gemakkelijk worden getrokken.

Behalve bij de zomergerst, is de opbrengst van de gewassen op de niet geondergronde strook lager dan op de beide andere stroken. Dit spreekt het duidelijkst bij de veldjes welke geen stikstofbemesting ontvingen.

Een verklaring voor het afwijkende gedrag van de zomergerst is niet te geven. Op kavel C $62 \mathrm{kwam}$ dit gedrag in 1957 ook voor. De ondervrucht luzerne zou de oorzaak kunnen zijn, indien er een overeenkomstige invloed bij het vlas zou zijn te merken geweest. Het gedrag van het vlas met luzerne-ondervrucht is echter geheel in overeenstemming met dat van de overige gewassen.

De aëratie onder de wintertarwe was in mei als volgt:

$\begin{array}{lccc}\text { Strook: } & \text { I }(70 \mathrm{~cm}) & \text { II }(50 \mathrm{~cm}) & \text { III }(20 \mathrm{~cm}) \\ \text { Geheel geaëreerd } & 55 \mathrm{~cm} & 45 \mathrm{~cm} & 35 \mathrm{~cm} \\ \text { Ongeaëreerd } & 70, & 60 " & 55 . " \\ \text { Grens beworteling } & 73, & 63 " & 50 "\end{array}$

Van de zomergerst werden naaldenplankmonsters genomen dwars over twee rijen heen. $\mathrm{Na}$ het uitspoelen werden de tussen-gezaaide luzerneplanten verwijderd. In tabel 42 is de wortelverdeling a vermeld.

TABez 42. Verdeling (\%) van de wortels van zomergerst in de laag $20-70 \mathrm{~cm}$ van het ondergrondbewerkingsproefveld op kavel D 24 in 1954, en de hoeveelheden wortels $(\mathrm{mg})$ in blokken van $10 \times 23 \times 50 \mathrm{~cm}^{3}$.

\begin{tabular}{l|c|c|c}
\hline Strook: & $\cdots$ & II $\cdots$ & III \\
\hline & & & \\
\hline & 26 & 38 & 51 \\
$30-40 \mathrm{~cm}$ & 24 & 45 & 33 \\
$40-50 \mathrm{~cm}$ & 29 & 16 & 14 \\
$50-60 \mathrm{~cm}$ & 21 & 1 & 2 \\
$60-70 \mathrm{~cm}$ & Sp & 0 & 0 \\
$20-70 \mathrm{~cm}$ & $760 \mathrm{mg}$ & $405 \mathrm{mg}$ & $477 \mathrm{mg}$ \\
\hline
\end{tabular}

$\mathrm{Na}$ het rooien werden de suikerbieten weer in normale, korte en sterk vertakte bieten ingedeeld. De resultaten van de telling waren als volgt:

$\begin{array}{rccr} & \text { Normal } & \text { Kort } & \text { Vertakt } \\ \text { I } & 48 \% & 47 \% & 5 \% \\ \text { II } & 45 \% & 44 \% & 11 \% \\ \text { III } & 35 \% & 55 \% & 10 \%\end{array}$


3. Voor het seizoen 1954-1955 werd eind november een aantal akkers op $\pm 20 \mathrm{~cm}$ diepte geploegd. Eind maart werden twee van de resterende akkers op $\pm 10 \mathrm{~cm}$ diepte geploegd en de overige op $\pm 20 \mathrm{~cm}$ diepte. De twee akkers met luzerne bleven onbewerkt. Er was dit voorjaar weinig verschil in structuur tussen de verschillende ondergrondbewerkingsstroken.

De volgende gewassen werden verbouwd:

Suikerbieten (Klein Wanzleben E), na wintertarwe, bemesting $700 \mathrm{~kg} / \mathrm{ha}$ kas, op drie akkers, resp. geploegd in nov. op $20 \mathrm{~cm}$ en in maart op 20 en $10 \mathrm{~cm}$.

Aardappelen, (IJsselster), na groene erwten; bemesting $700 \mathrm{~kg} / \mathrm{ha} \mathrm{kas}$ op één akker, in maart geploegd op $20 \mathrm{~cm}$.

Luzerne,

Zomergerst, (Ago), (tweede jaar),

na aardappelen. Ter controle van het afwijkende gedrag in 1954 werd hierop een proef met opklimmende hoeveelheden stikstofmeststof gelegd. Op één akker, in november op $20 \mathrm{~cm}$ geploegd.

Groene erwten, (Rondo): na zomertarwe, op twee akkers, resp. in november en maart op $20 \mathrm{~cm}$ geploegd.

Vlas, (Wiera),

na haver, bemesting $150 \mathrm{~kg} / \mathrm{ha} \mathrm{kas}$, op twee akkers, resp. in november en maart geploegd op $20 \mathrm{~cm}$ diep.

Haver, (Marne), na suikerbieten, bemesting $200 \mathrm{~kg} / \mathrm{ha} \mathrm{kas}$, op drie akkers, resp. in november geploegd op $20 \mathrm{~cm}$ en in maart op 20 en $10 \mathrm{~cm}$.

TABEL 43. Gemiddelde opbrengsten (kg/are) van de zomergerst van de proef met opklimmende hoeveelheden stikstofmeststof op het ondergrondbewerkingsproefveld op kavel D 24 in 1955.

\begin{tabular}{|c|c|c|c|c|c|c|c|c|}
\hline $\mathrm{Kas}(\mathrm{kg})$ & & 0 & 100 & 150 & 200 & 250 & 300 & 350 \\
\hline Korrels & $\begin{array}{r}\left.\mathbf{I}^{\prime}\right) \\
\left.\mathbf{I I}^{\prime}\right\rangle \\
\left.\mathbf{I I}^{\prime}{ }^{\prime}\right)\end{array}$ & $\begin{array}{l}28.8 \\
25.1 \\
20.5\end{array}$ & $\begin{array}{l}34.9 \\
31.6 \\
27 .-\end{array}$ & $\begin{array}{l}38.2 \\
35.3 \\
33.4\end{array}$ & $\begin{array}{l}42.3 \\
38.7 \\
36.8\end{array}$ & $\begin{array}{l}44.1 \\
41.5 \\
39.3\end{array}$ & $\begin{array}{l}45.2 \\
43.8 \\
42 .-\end{array}$ & $\begin{array}{l}47.1 \\
46.2 \\
43.3\end{array}$ \\
\hline Stro & $\begin{array}{r}\text { I } \\
\text { II } \\
\text { III }\end{array}$ & $\begin{array}{l}27.5 \\
24.4 \\
19.7\end{array}$ & $\begin{array}{l}35.6 \\
34.2 \\
28.4\end{array}$ & $\begin{array}{l}39.9 \\
37.8 \\
36.6\end{array}$ & $\begin{array}{l}44.8 \\
42.8 \\
40.7\end{array}$ & $\begin{array}{l}46.6 \\
46.2 \\
43.9\end{array}$ & $\begin{array}{l}51.6 \\
50.9 \\
47.5\end{array}$ & $\begin{array}{l}52.9 \\
53.4 \\
49 .-\end{array}$ \\
\hline
\end{tabular}

') zie tabel 37. 
Gedurende de groei waren er in het algemeen geen opvallende verschijnselen bij de gewassen te zien die verband hielden met de grondbewerking.

De ontwikkeling van de zomergerst was op de stroken met ondergrondbewerking steeds iets voor bij die zonder ondergrondbewerking. De aardappels hadden op de niet geondergronde strook eerder te lijden van de droogte.

Ofschoon soms wel enig verschil tussen de akkers met verschillende ploegtijden of ploegdiepten viel op te merken, gaven de opbrengsten geen aanleiding om de uitkomsten van de akkers apart te vermelden.

Uit tabel 43 blijkt dat de zomergerst op de strook zonder ondergrondbewerking lagere opbrengsten heeft dan op de stroken met ondergrondbewerking.

TABEL 44. Gemiddelde opbrengsten ( $\mathrm{kg} /$ are) van suikerbieten, aardappelen, groene erwten, luzerne, vlas en haver op het ondergrondbewerkingsproefveld op kavel D 24 in 1955.

\begin{tabular}{r|c|c|c|c|c|c|c}
\hline & \multicolumn{3}{|c|}{ Suikerbieten } & \multicolumn{3}{|c}{ Aardappelen } \\
\hline & Bieten & Loof & $\begin{array}{c}\text { Suiker } \\
\%\end{array}$ & Suiker & Cons. & O.w.g. $\left.{ }^{2}\right)$ & Fabriek $^{3}$ ) \\
& & & & & & \\
\hline$\left.I^{\prime}\right)$ & 474 & 344 & 17.23 & 86 & 401 & 490 & 507 \\
$\left.I^{\prime}\right)$ & 459 & 344 & 16.95 & 81 & 371 & 494 & 474 \\
$\left.I^{\prime}\right)$ & 441 & 337 & 16.85 & 77 & 349 & 493 & 446 \\
\hline
\end{tabular}

\begin{tabular}{r|c|c|c|c|c|c}
\hline & \multicolumn{2}{|c|}{ Groene erwten } & Luzerne & Vlas & \multicolumn{2}{c}{ Haver } \\
\hline & \multirow{2}{*}{ Korrel } & Stro & Droge stof & Ongerepeld & Korrel & Stro \\
& & & & & & \\
\hline II & 46.7 & 33.8 & 979 & 93.5 & 49.7 & 47.0 \\
II & 46.8 & 35.6 & 978 & 91.8 & 48.6 & 44.7 \\
& 44.5 & 32.8 & 929 & 85.1 & 43.5 & 40.7 \\
\hline
\end{tabular}

1) Zie tabel 37

2) O.w.g. = onder-water-gewicht.

3) Fabrieksgewicht met standaard o.w.g. van 400

De opbrengsten zijn op de geondergronde stroken hoger dan op de niet geondergronde strook. 
Van alle gewassen werd de beworteling onderzocht. Hierbij werd bij enkele gewassen geconstateerd, dat de tot $70 \mathrm{~cm}$ diepte losgemaakte strook in de ondergrond minder intensief was doorworteld dan de tot $50 \mathrm{~cm}$ diepte losgemaakte. Vooral bij het vlas en de haver viel dit sterk op. De zomergerst en luzerne toonden dit niet zozeer, evenmin als de aardappelen en suikerbieten.

TABEL 45. Verdeling (\%) van de wortels van zomergerst in de laag $20-70 \mathrm{~cm}$ van het ondergrondbewerkingsproefveld op kavel D 24 in 1955, en de hoeveelheden wortels in blokken van $10 \times 23 \times 50 \mathrm{~cm}^{3}$.

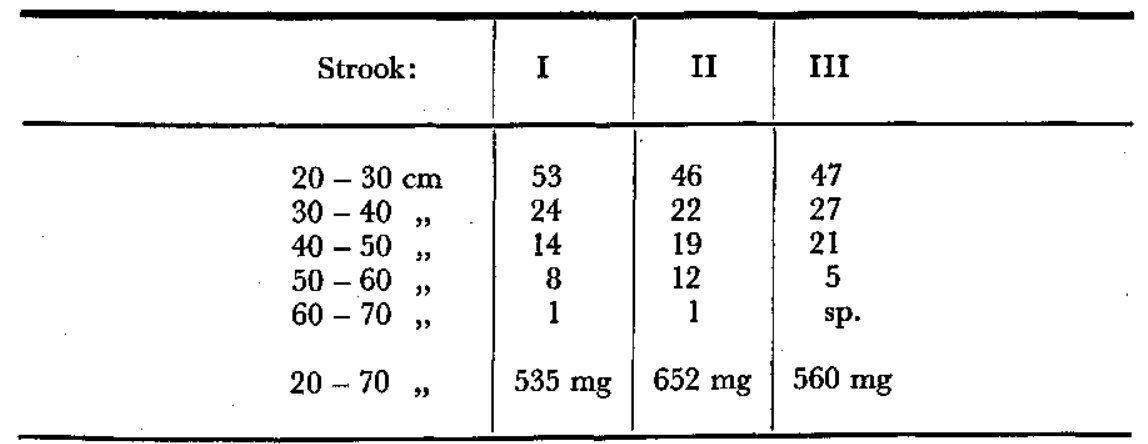

\section{Samenvatting}

In de herfst van 1952 werden in de lengterichting van kavel D 24 de volgende ondergrondbewerkingen toegepast:

1. Tot $70 \mathrm{~cm}$ diepte breken met de Neptunus.

II. Tot $50 \mathrm{~cm}$ losmaken met de Mc. Cormick met ondergronders.

III. Geen ondergrondbewerking.

Dwars over deze stroken werden verschillende gewassen verbouwd, waarop de invloed van de ondergrondbewerking en de stikstofbemesting werd gecontroleerd.

De volgende resultaten werden verkregen op de stroken met ondergrondbewerking, in vergelijking met de niet geondergronde strook:

1. Een geringe, doch steeds voorkomende opbrengstverhoging.

2. Een iets geringere stikstofbehoefte.

3. Een zeer sprekende verbetering van de rijping en doorworteling van de ondergrond.

4. Een verbeterde ontwatering, met als gevolg het grotendeels achterwege blijven van structuurverval van de bouwvoor gedurende de winter.

5. Een vergemakkelijking van de grondbewerking en de oogstwerkzaamheden wegens de drogere bouwvoor in voorjaar en herfst.

6. De diepste ondergrondbewerking had de eerste jaren de beste resultaten; de minder diepe bewerking met de Mc. Cormick met ondergronders lijkt op den duur enige voorkeur te verdienen, wellicht omdat de ondergrond intensiever wordt losgemaakt. 
7. De niet losgemaakte ondergrond is in de loop van de proefjaren verder gerijpt, waarbij de beworteling is verbeterd.

Beschouwing over de ondergrondbewerkingsproefvelden.

De doelstellingen van de ondergrondbewerking: verbetering van de rijping en de ontwatering van de grond, het losmaken van harde lagen en de verbetering van de beworteling zijn bij alle proefvelden bereikt. Indien hiermede eveneens in alle of de-meeste gevallen een duidelijke (en liefst aanzienlijke) verhoging van de produktie zou zijn verkregen, zou een verdere beschouwing overbodig zijn, omdat de verbeterde groeivoorwaarden inderdaad tot uiting zouden zijn gekomen. Bij de behandeling van de betekenis van het wortelbeeld voor de plant werd echter reeds naar voren gebracht, dat niet het wortelbeeld (uitgebreidheid van het wortelstelsel) van doorslaggevende betekenis is voor de produktie, maar de beschikbaarheid van voldoende voedsel en vocht in de doorwortelbare ruimte.

Het is nu de vraag, of het produktie-niveau van de betrokken proefvelden zonder ondergrondbewerking te laag is en, zo ja, of inderdaad de oorzaak hiervan is gelegen in het feit, dat de doorwortelbare ruimte onvoldoende omvang heeft.

Ten aanzien van het produktie-niveau is geen positieve uitspraak mogelijk. Als vergelijkingsobjecten waren alleen aanwezig de opbrengstgegevens van de Cultuurtechnische Afdeling, verkregen gedurende de tijdelijke exploitatie, voorafgaande aan de uitgifte van de bedrijven aan de pachters. De waarde van de gegevens is zeer beperkt, daar:

1. het aantal jaren dat een bepaalde kavel of groep van kavels in exploitatie is, in de regel zeer gering is;

2. de voorgeschiedenis (gedurende en voorafgaande aan de ontginning) zeei uiteenloopt;

3. de vruchtopvolging niet gelijk is;

4. het niet mogelijk is alle kavels in een bepaald gebied op de meest gewenste tijd en onder de gunstigste omstandigheden te bewerken;

5. de opbrengstbepalingen aan grote fouten onderhevig zijn, o.a. ten gevolge van moeilijkheden bij de bepaling van de oppervlakte (begreppeld. land);

6. gedurende de tijdelijke exploitatie de grond van jaar tot jaar voortdurend beter wordt (voortgaande rijping).

Het is evenwel mogelijk aan te geven, of een bepaalde opbrengst afwijkt van hetgeen volgens een algemene indruk of ervaring verwacht kan worden. Zonder nu met exacte cijfers te werken, kan worden gezegd, dat, ten opzichte van de gemiddelde opbrengsten in de Noordoostpolder, en in aanmerking genomen dat de proefvelden wel een voldoende verzorging ondervonden en het opbrengstniveau van proefvelden altijd wat hoger is dan van de praktijk, de opbrengsten op het proefveld op:

1. kavel $Q 65$

2. kavel O 98 aan de norm voldeden; te laag waren; 
3. kavel M 128 a. op het grote proefveld in 1948 en 1951 te laag waren en in 1949 ruimschoots aan de norm voldeden;

b. op het kleine proefveld in beide jaren te laag waren;

4. kavel B 68 a. in 1952 van de granen te laag en van de overige: gewassen goed waren;

b. in 1953 van alle gewassen aan de norm voldeden;

5. kavel C 62 a. in 1952 van de granen te laag waren en verder goed;

b. in 1953 van alle gewassen aan de norm voldeden;

c. in 1954 van alle gewassen ruimschoots aan de norm voldeden;

6. kavel D 24 in 1953,1954 en 1955 ruimschoots aan de norm voldeden.

Hieruit volgt, dat alleen van de proefvelden op de kavels $\mathrm{O} 98$ en M 128 een opbrengstverhoging mocht worden verwacht.

Op beide kavels is deze inderdaad verkregen, maar nog niet voldoende om met de produktie op het gemiddelde peil te komen.

Als oorzaken voor de onvoldoende verbetering op kavel O 98 kunnen worden beschouwd het niet kunnen benutten van de betere ontwateringstoestand op de geondergronde stroken om vroeger te zaaien, en het structuurbederf dat is opgetreden tijdens de eerste bewerking in het voorjaar van 1949 .

Op kavel M I28 was de verbetering van de vochtvoorziening niet voldoende om het gemiddelde opbrengstpeil te bereiken.

Op deze en de overige proefvelden is de opbrengst dus niet of slechts in geringe mate verhoogd, ondanks de toch duidelijke verbeteringen in ander opzicht.

Een soortgelijke ervaring wordt algemeen opgedaan. WeLls definieert de ondergrondbewerking als een manier van diepe grondbewerking waarbij de ondergrond wordt verstoord en losgemaakt, doch niet wordt gekeerd of naar de oppervlakte gebracht. In een literatuuroverzicht laat deze auteur zich nogal pessimistisch uit over de met een ondergrondbewerking te bereiken resultaten.

Een ondergrondbewerking wordt volgens hem uitgevoerd ten einde: l. de doorlatendheid te vergroten;

2. de waterberging te vergroten ter voorkoming van droogteschade;

3. het doorwortelbare volume te vergroten, opdat meer voedsel en water ter beschikking van de plant kan komen.

Deze doelstellingen komen dus overeen met hetgeen in het begin van dit hoofdstuk als doel van de ondergrondbewerking in de Noordoostpolder werd genoemd, en zijn eveneens gelijk aan hetgeen anderen ervan verwachten.

Een verbetering van de doorlatendheid wordt in het algemeen wel bereikt, zoals Wells, Merbitz en Nitsch, Schultze en Herjl vermelden. De verbeterde ontwateringstoestand en dientengevolge betere bewerkbaarheid van de bouwvoor worden door enkele van deze auteurs genoemd, zonder dat zij er echter enige consequenties aan verbinden. 
WELLS vermeldt echter, dat een doorlatende grond door een ondergrondbewerking minder doorlatend kan worden als gevolg van een verstoring van aanwezige gangen. Indien al een verbetering van de ontwatering wordt verkregen dan vergoedt ze volgens hem nooit de kosten.

Over de mogelijkheid van losmaken merkt WELLS op, dat een „claypan" meestal te nat is om te kunnen worden gebroken.

Indien de laag echter voldoende is opgedroogd en dan wordt gebroken, zakt ze na nat worden weer in elkaar.

De ervaringen van WoodrufF en SMITk zijn gunstiger dan die van de door Wells aangehaalde auteurs. $Z$ ij verkregen na het breken van een droge "claypan" en het bekalken van deze laag een zeer duidelijke wortelontwikkeling. Ofschoon de bekalking een duidelijk effect op de doorworteling had, kan een deel van de verbeterde wortelgroei ook aan het losmaken worden toegeschreven. Een achteruitgang van de doorlatendheid werd niet geconstateerd. Het ,vastleggen" van de losse structuur door middel van de penwortels van honingklaver (of luzerne) is hierbij wel belangrijk.

Bij het verbreken van harde lagen (b.v. B-horizonten), is men het er algemeen over eens, dat hiermede een goede en blijvende verbetering wordt verkregen.

Het is merkwaardig dat, indien al een verbeterde ontwatering van de bouwvoor wordt geconstateerd, men over het algemeen het belang hiervan niet inziet of vermeldt. Dit zal komen door het feit dat de natuurlijke ontwatering, door de ligging op hellingen, geen aanleiding tot plasvorming op natte plekken gaf (ScHulTze), of doordat de ondergrondse afvoer van het water onvoldoende was om de betere verticale waterbeweging ten volle te benutten. In het laatste geval is het.enige nut van het losmaken gelegen in een grotere waterberging van de grond, indien tenminste het volume van het profiel door vergroting van het poriën-aandeel is toegenomen.

De onvoldoende ondergrondse afvoer was bij de proefvelden in de Noordoostpolder ook aanwezig, indien de ondergrondbewerking evenwijdig aan de greppels of de drains werd uitgevoerd. Het was blijkbaar nodig, dat in een dichte ondergrond door een "molploeg"-achtige werking van de werktuigen de verbinding tussen ondergrond en drain werd verbeterd.

Een verbeterde ontwatering van de bouwvoor werd echter in de Noordoostpolder op alle proefvelden verkregen. In een enkel geval (kavel D 24) veroorloofde de proefopzet van deze verbetering te profiteren door vroeger te zaaien. Dat de vroegere zaaitijd door omstandigheden in dit geval geen hogere opbrengst met zich bracht, doet niets af aan de algemene ervaring, dat vroeg zaaien van zomergranen gunstig is voor de opbrengst.

Het machinale oogsten van de aardappelen en de suikerbieten profiteert eveneens van een droge bouwvoor, deels omdat de benodigde trekkracht daardoor geringer kan zijn, deels omdat minder grondtarra behoeft te worden verwerkt. Ook is structuurbederf ten gevolge van het 
rijden over de grond op droog land geringer dan op nat land.

In de praktijk, dat wil zeggen bij werken over grote oppervlakten, spreken deze voor- en nadelen nog sterker dan op proefvelden. Juist omdat meer of minder grote verschillen in de toestand van de bouwvoor op proefvelden minder moeilijkheden met zich brengen - daar de meeste werkzaamheden met de hand worden verricht of omdat de moeilijke velden (veldjes) in de regel net klein genoeg zijn om bij machinaal werk geen oponthoud te veroorzaken - mogen zij niet aan de aandacht ontsnappen. Een voor een proefveld iets te natte bouwvoor kan op een praktijkperceel de werkzaamheden dagenlang onmogelijk maken.

Een verbetering van de vochtvoorziening der gewassen door de vergroting van de waterberging is weinig waarschijnlijk, daar hiervoor de aard van de grond zodanig moet zijn dat elke volumevergroting als gevolg van de ondergrondbewerking moet gehandhaafd blijven. Want voor elke $10 \mathrm{~mm}$ grotere waterberging zou de bovenkant van de grond blijvend $1 \mathrm{~cm}$ hoger moeten blijven liggen. Waar dus een tekort van $100 \mathrm{~mm}$ bestaat, dient de structuur van het profiel zodanig te zijn dat het niveau van de grond blijvend $10 \mathrm{~cm}$ hoger komt te liggen, en bovendien moeten de ontstane poriën dan zodanig zijn, dat zij inderdaad het water vasthouden. Het is echter wel aannemelijk, dat door verbetering van de toegankelijkheid het aanwezige water geheel opneembaar wordt.

WELLS concludeert uit onderzoekingen over de gehele wereld, dat in het merendeel der gevallen geen verbetering van de opbrengst door ondergrondbewerking werd verkregen, tenzij harde lagen werden verbroken. Uit de onderzoekingen van Schultze, Heijl, Woodruff en SMITH en Buess kan worden afgeleid, dat in de meeste gevallen ook geen of slechts een geringe opbrengstverhoging werd geconstateerd, indien wel een dichte laag werd verbroken.

De gegevens van Buess en Heiju over het water- en luchtgehalte der ondergronden van hun proeven zijn niet te vergelijken met de conclusie die Wesseling en Bertrand en KoHNke hebben getrokken ten aanzien van het noodzakelijke luchtgehalte om een voldoende zuurstofdiffusie te verzekeren. Buess geeft alleen het totale gehalte en Heiju de gehalten bij of vlak voor de oogst. Uit hun gegevens kan echter wel worden afgeleid, dat de wortelontwikkeling zeer verbeterde, maar zonder duidelijke 'gevolgen voor de opbrengst.

Buess vermeldt trouwens, dat de geconstateerde verdichting betrekkelijk gering was.

Het lijkt wel zeer moeilijk te zijn om op grond van proefwaarnemingen en bepalingen van lucht- en watergehalten te voorspellen, of door een ondergrondbewerking een opbrengstverhoging zal worden verkregen.

Samenvatting van de waarnemingen op de proefvelden

Gedurende de jaren 1949-1955 werden op verschillende profielen in de Noordoostpolder ondergrondbewerkingsproefvelden aangelegd. Deze hadden tot doel: het nagaan van de invloed van het losmaken van zand 
en/of sloef in de ondergrond op de groei van Iandbouwgewassen en op de rijping van de grond.

De resultaten waren als volgt:

1. De rijping en doorworteling van de ondergrond waren sterk verbeterd, met als gevolg een geringere kans op verdroging.

2. De gewassen ontwikkelden zich beter en vlugger, waardoor hun weerstand tegen ongunstige omstandigheden, naar zich laat aannemen, werd verhoogd.

3. De ontwateringstoestand van de grond werd beter, waardoor de bewerking van de bouwvoor lichter werd en de kans op structuurbedert geringer. Dit houdt tevens in, dat zo de bouwvoor een groter deel van.het jaar bewerkbaar wordt.

4. De vorm van de bieten werd over het algemeen verbeterd, met als gevolg de kans op een geringere hoeveelheid grondtarra.

5. Een ondergrondbewerking heeft het meeste effect, indien de grond tijdens de bewerking zo droog mogelijk is.

6. Het voordeel van een ondergrondbewerking moet voornamelijk worden gezien in een verbetering van de omstandigheden waaronder de gewassen worden geteeld en geoogst, en niet in een directe opbrengstverhoging. De betere bewerkbaarheid van de grond, het geringere risico bij de groei van de gewassen en de gemakkelijkere oogstwerkzaamheden moeten tot gevolg hebben, dat het verschil tussen de bruto-opbrengst en de kosten, nodig om die bruto-opbrengst te verkrijgen, groter wordt.

Ter illustratie van de invloed op de structuur van de grond geven de figuren 54,55 en 56 een indruk van de toestand zonder ondergrondbewerking, en de figuren 57,58 en 59 een indruk van de toestand na ondergrondbewerking. 


\section{DE PRAKTIJK DER ONDERGRONDBEWERKING IN DE NOORDOOSTPOLDER}

\section{Inleiding}

De Cultuurtechnische Afdeling van de Directie van de Wieringermeer (Noordoostpolderwerken) heeft in twee gebieden in de Noordoostpolder op grote schaal ondergrondbewerkingen uitgevoerd.

Het eerste gebied, voornamelijk in de jaren 1949-1951 aangepakt, omvat sectie $O$ en het gedeelte van sectie $Q$ ten noordwesten van de Zuiderringweg. Dit gebied wordt meestal aangeduid als het sloefgebied. De hier soms direct onder de bouwvoor aanwezige sloef, zowel droge als vette, werd losgemaakt met ploegen, voorzien van ondergronders. Waar in dit gebied tussen bouwvoor en sloef een dikke laag zware zavel voorkwam, werd gebruik gemaakt van de vernielploeg, om, door middel van in de grond getrokken sleuven, de ontwatering te verbeteren. In een gedeelte van dit gebied komt tussen deze laag zware zavel (ZU II) en de sloef een vrij dikke zandlaag voor (Zu III). Uiteraard werd deze ook losgemaakt. Indien deze zandlaag echter lag boven een andere zavellaag (Zus of $\mathrm{Zu} \mathrm{IV),} \mathrm{werd} \mathrm{de} \mathrm{noodzaak} \mathrm{om} \mathrm{een} \mathrm{ondergrondbewerking} \mathrm{uit} \mathrm{te}$ voeren niet groot geacht. Zo nodig werd kavel voor kavel bekeken om de meest geschikt geachte ondergrondbewerking vast te stellen.

Gedurende deze jaren werd veel ervaring opgedaan met de ondergrondbewerking en kwamen veel verbeteringen tot stand aan de werktuigen.

Daar het hier een betrekkelijk klein gebied betrof, werd aan de-hand van een eenvoudig kaartje en in geregeld overleg de ondergrondbewerking uitgevoerd.

Het tweede gebied ligt ten westen van een lijn die even ten westen van Lemmer begint, over Rutten en Tollebeek naar Nagele loopt en vervolgens zuidwaarts naar de dijk. Bij dit gebied hoort bovendien nog het gedeelte van sectie J tussen Nagelerweg en Urkervaart. Een zeer bont gebied in de omgeving van Urk wordt buiten beschouwing gelaten.

Dit tweede gebied was te uitgebreid om zo maar te kunnen worden aangevat. Het werd nodig geoordeeld voor dit gebied een plan te ontwerpen waarin voor elke kavel of groep van kavels de meest gewenste ondergrondbewerking werd aangegeven.

Dat in dit gebied een ondergrondbewerking nodig was, hetzij voor een betere beworteling, hetzij voor een betere ontwatering, was reeds ge- 
bleken bij het bewortelingsonderzoek in dit gebied. Deze noodzaak werd bevestigd door de eerste indrukken die de ondergrondbewerkingsproefvelden gaven en door de resultaten van de proefnemingen met de pas ontwikkelde ondergrondbreker op greppelploegonderstel, de Neptunus.

Een uitvoerig plan was nodig, zowel ter bepaling van het benodigde aantal en soort van werktuigen als voor het verdelen van de werkzaamheden over de komende jaren.

In de winter 1951-1952 werd aan de hand van gegevens van de Bodemkundige Afdeling der Noordoostpolderdirectie en eigen waarnemingen voor de Cultuurtechnische Afdeling dit plan gemaakt.

In de eerste plaats werd nagegaan, welke profielen een ondergrondbewerking moesten ondergaan; daarna werd vastgesteld, tot welke diepte dit minstens diende te gebeuren. Ten slotte werd aangegeven voor welke gebieden de grootste noodzaak bestond, en waar een ondergrondbewerking wel goed zou zijn, maar het achterwege blijven niet bezwaarlijk.

De resultaten van het in de vorige alinea bedoelde onderzoek zijn vastgelegd in drie kaarten.

Kaart 1 geeft een overzicht van de probleemgebieden. Hiermede wordt bedoeld, dat is aangegeven welk probleem in elk der gebieden diende te worden opgelost ter verbetering van beworteling, rijping en ontwatering.

Kaart 2 geeft aan, welke minimum bewerkingsdiepte gewenst is.

Kaart 3 geeft aan waar de ondergrondbewerking moet gebeuren en waar het kan gebeuren.

Overzicht van de afzettingen, welke dienden te worden losgemaakt

De afzettingen welke in het betrokken gebied bezwaren opleverden, zijn de volgende:

a. De Zu III.

Deze zandlaag is van weinig betekenis indien zij dun is, ook al vormt zij tijdelijk een scherpe scheiding in de aëratie. Is de laag dik $(4-10 \mathrm{~cm})$, dan wordt de beworteling nadelig beïnvloed en dat wel te meer, naarmate de onderliggende laag een lager lutumgehalte heeft.

Voorts heeft de diepte waarop de laag voorkomt, invloed. In sectie $H$, waar de Zu III enkele centimeters dik is en op $25-30 \mathrm{~cm}$ diepte voorkomt, is de laag hinderlijker dan in sectie $\mathrm{E}$, waar zij $7-10 \mathrm{~cm}$ dik is en op 40 en $50 \mathrm{~cm}$ diepte voorkomt.

b. Het Espelzand.

Dit is eigenlijk een heel dikke Zu III en daarom geldt het over de Zu III vermelde ook voor het Espelzand. Het Espelzand vormt een $10-30 \mathrm{~cm}$ dikke zandlaag onder de bouwvoor en is daarom van een onderbreking van het profiel tot een deel van het profiel geworden. De dikke Espelzandlagen zijn niet toegankelijk voor de wortels, althans aanvankelijk niet. 
c. De „droge" sloef.

Dit kan Sl. I a, I b, II a en III a zijn. Meestal is de sloef sterk gelaagd, afwisselend zand en humeuze laagjes. Hierin dringen de wortels niet door. Meestal komt deze sloef zo diep voor, dat de erdoor aan de beworteling opgelegde beperking niet belangrijk is. Deze sloef ligt steeds dieper dan $40 \mathrm{~cm}$ beneden maaiveld. Voor de ontwatering is deze sloef wel lastig.

d. De lichte zavel A.

Voor de beworteling levert deze lichte zavel geen moeilijkheden op, echter wel voor de ontwatering.

e. De lichte zavel A-sloef.

Deze grond staat in eigenschappen tussen lichte zavel A en droge sloef. Het gelaagde karakter is de oorzaak van de slechte doorworteling.

f. De lichte zavel B.

Gewoonlijk geeft deze grondsoort geen aanleiding tot moeilijkheden bij de beworteling en ontwatering.

In sectie $\mathbf{G}$ en plaatselijk in sectie $\mathbf{E}$ is deze zavel echter gelaagd; de doorworteling is matig.

Verbreking van de gelaagdheid heft de moeilijkheden op. Hetzelfde geldt voor de lichte zavel A-sloef.

g. Schelpen.

Deze komen soms in grote hoeveelheden in de lichte zavel, het Espelzand en de Zu III voor. Daar ze steeds ingebed zijn in zand, zijn ze hinderlijk voor de beworteling en de ontwatering. Door een ondergrondbewerking, waarbij de horizontale ligging wordt verstoord, worden de moeilijkheden meestal verholpen.

Waar (zoals in sectie $H$ ) veel schelpen in de bouwvoor aanwezig zijn, kan vaak door bovenploegen van de onder de bouwvoor liggende zwaardere zavel de hindernis worden opgelost.

\section{Het plan voor de ondergrondbewerking}

De probleemgebieden van kaart 1 (fig. 16) zijn als volgt samengesteld:

a. Espelzand op zandige sloef.

Ligging in sectie A en een deel van sectie B.

Het Espelzand met de zandige sloef ligt ter dikte van $40-100 \mathrm{~cm}$ op veen. De ondergrondbewerking dient te geschieden tot aan het veen. In het veen werken de ondergronders niet.

b. Lichte zavel op schelphoudend Espelzand.

Dit omvat het grootste gedeelte van de secties B, C en D, en een gedeelte van sectie $\mathrm{E}$.

In sectie $\mathrm{D}$ komt in de ondergrond een betrekkelijk dikke, lichte zavel B laag voor, in sectie $\mathbf{E}$ is de bouwvoor plaatselijk zwaarder. Een bewerking tot 50 à $60 \mathrm{~cm}$ wordt nodig geacht.

Een gedeelte van dit gebied in sectie $\mathrm{E}$ is door diepploegen verbeterd. 


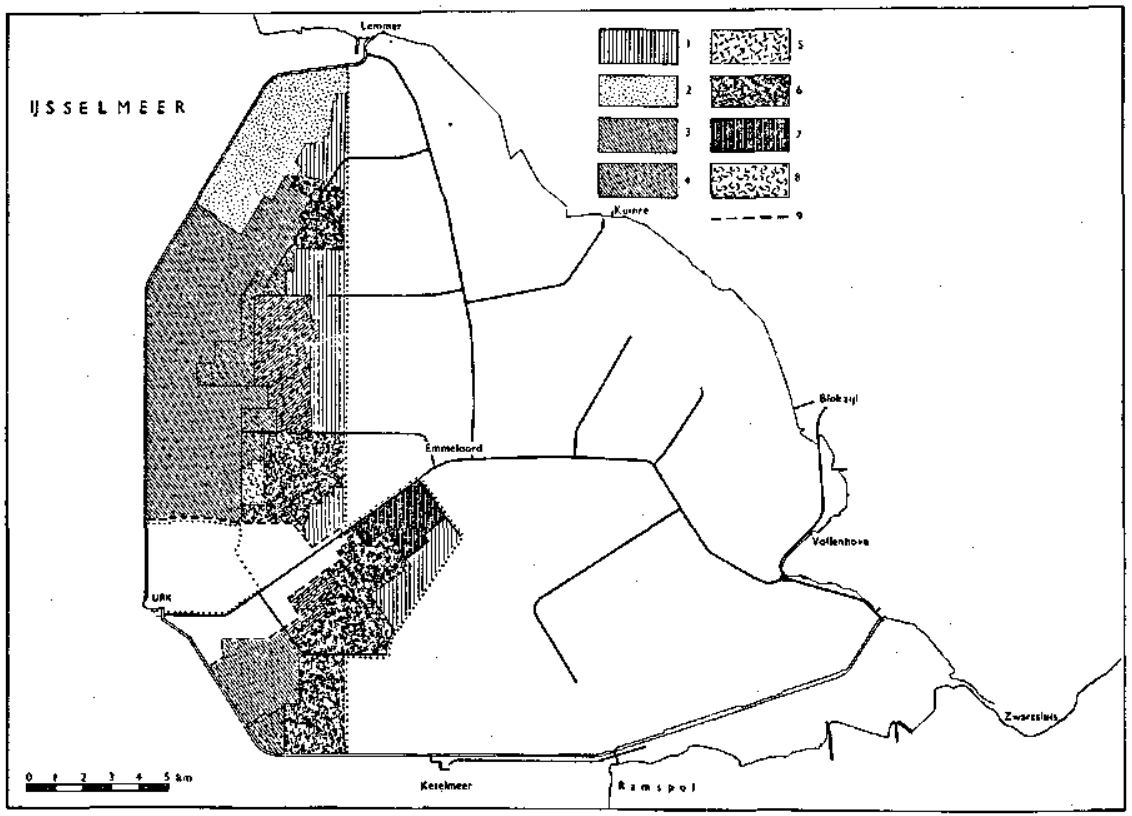

Fig. 16

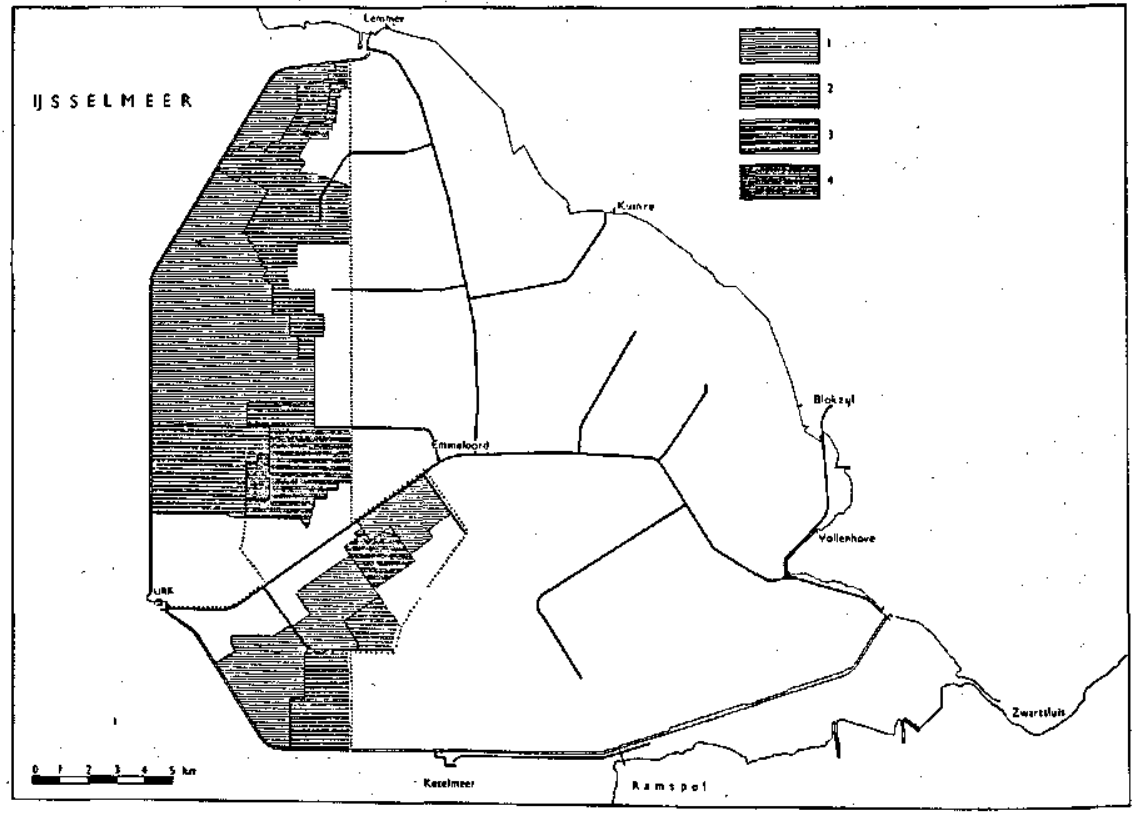

Fig. 17 
Fig. 16. Oorzaken van onvoldoende dieptegroei van de wortels. Causes of insufficient root development.

1. Geen storende lagen in het profiel.

Profile without layers or horizons stunting the growth of roots.

2. Espelzand op zandige sloef. Loamy sand overlying silt loam.

3. Lichte zavel op schelphoudend zand.

Sandy loam oyerlying sand with many shells.

4. Meer dan $25 \mathrm{~cm}$ lichte zavel $\mathrm{A}+\mathrm{Zu}$ III op lichte ondergrond. More than $25 \mathrm{~cm}$ sandy loam and loamy sand (Zu III) overlying light textured subsoil.

5. Lichte zavel $B$, droge sloef in de ondergrond. (Sandy) loam, silt loam in the subsoil.

6. Storende $\mathrm{Zu}$ III.

Layer Zu III, stunting the growth of roots.

7. Zware zavel, droge sloef in de ondergrond.

Loam, silt loam in the subsoil.

8. Zeer veel schelpen in lichte bouwvoor.

Many shells in topsoil of sandy loam.

9. Bont gebied.

Area with varying soil conditions.

Fig. 17. Gewenste diepte voor de ondergrondbewerking. Desirable depth of subsoiling.

1. Ondergronden tot maximale diepte $(70 \mathrm{~cm})$. Subsoiling as deep as possible $(70 \mathrm{~cm})$.

2. Ondergronden tot 40 à $60 \mathrm{~cm}$ diepte.

Subsoiling to a depth of 40 to $60 \mathrm{~cm}$.

3. Ondergronden tot 35 à $40 \mathrm{~cm}$ diepte.

Subsoiling to a depth of 35 to $40 \mathrm{~cm}$.

4. Diepploegen tot 50 a $60 \mathrm{~cm}$ diepte.

Deep ploughing to a dept of 50 to $60 \mathrm{~cm}$. 
c. Lichte zavel A op Zu III.

Een smalle strook in de secties $B, C$ en $D$ en een in sectie $H$, benevens een hoek van sectie $\mathbf{E}$.

In de secties B en C komt onder de Zu III betrekkelijk hoog in het profiel droge sloef voor. Dit gedeelte moet $60 \mathrm{~cm}$ diep worden bewerkt. In de secties $\mathrm{D}$ en $\mathrm{H}$ komt onder $\mathrm{Zu}$ III Zus voor en ligt de droge sloef betrekkelijk diep. Hier is een bewerking tot $40 \mathrm{~cm}$ voldoende. In sectie $\mathbf{E}$ is de bouwvoor zwaarder en de $\mathrm{Zu}$ III dikker, zodat een bewerking tot $50 \mathrm{~cm}$ noodzakelijk wordt geacht.

d. Lichte zavel $\mathbf{B}$, droge sloef in de ondergrond.

Ligging in het oostelijk gedeelte van sectie $\mathrm{G}$ en het westelijk gedeelte van sectie $\mathrm{J}$.

In sectie $\mathrm{C}$ is de droge sloef lastig; ze dient tot $60 \mathrm{~cm}$ te worden losgemaakt.

In sectie $\mathrm{J}$ is de bovengrond zwaarder, de $\mathrm{Zu}$ III dikker en komt de droge sloef soms ook vrij hoog in het profiel voor. Dit profiel dient ook tot $60 \mathrm{~cm}$ diepte te worden losgemaakt.

e. Een storende $\mathrm{Zu}$ III.

Deze komt voor in het overblijvende gedeelte van het gehele beschreven gebied, met uitzondering van de gedeelten onder 6 en 7 . Over het algemeen komt de Zu III meer of minder hoog in het profiel voor en meestal bevindt zich exonder een vette en/of humeuze sloeflaag. Afhankelijk van de diepteligging en de dikte van de laag, wordt hier een bewerking variërend tussen $30 \mathrm{en} 60 \mathrm{~cm}$ diepte aanbevolen.

f. Zware zavel met droge sloef in de ondergrond.

Dit gedeelte ligt in sectie $J$, aansluitend bij het sloefgebied van sectie $\mathbf{O}$. Een zo diep mogelijke bewerking wordt aanbevolen.

g. Schelpengebied.

Dit omvat de zg. korte kavels van sectie $\mathrm{H}$ en het gedeelte van sectie $\mathrm{H}$ tussen Steenbanktocht, Urkervaart en Urkerdwarspad. Op de korte kavels is de laag schelpen in de bouwvoor door $\pm 30 \mathrm{~cm}$ diep te ploegen zodanig gemengd met de onderliggende zware zavel, dat zij geen probleem meer vormen.

Het tweede gedeelte van sectie $\mathbf{H}$ was dermate bont, dat alleen met een ondergrondbewerking geen verbetering was te verkrijgen. Dit gebied is voor een deel gediepploegd.

Kaart 2 (fig. 17) geeft een overzicht van de gewenste diepte van bewerking. Deze kaart geeft uiteraard een zeer vereenvoudigd beeld van hetgeen kaart 1 met toelichting wenst, dat wordt gedaan.

Daar er over het algemeen geen bezwaar bestaat tegen een diepere ondergrondbewerking, indien de werktuigen maar door een harde vaste laag lopen, heeft deze vereenvoudiging geen bezwaren.

Tenslotte geeft kaart 3 weer welke gebieden een ondergrondbewerking moeten hebben, en waar de ondergrondbewerking kan gebeuren. Deze laatste gebieden omvatten in hoofdzaak de profielen waarin alleen de $\mathrm{Zu}$ III storend is. Gezien de ligging van de zandlaag boven betrek- 


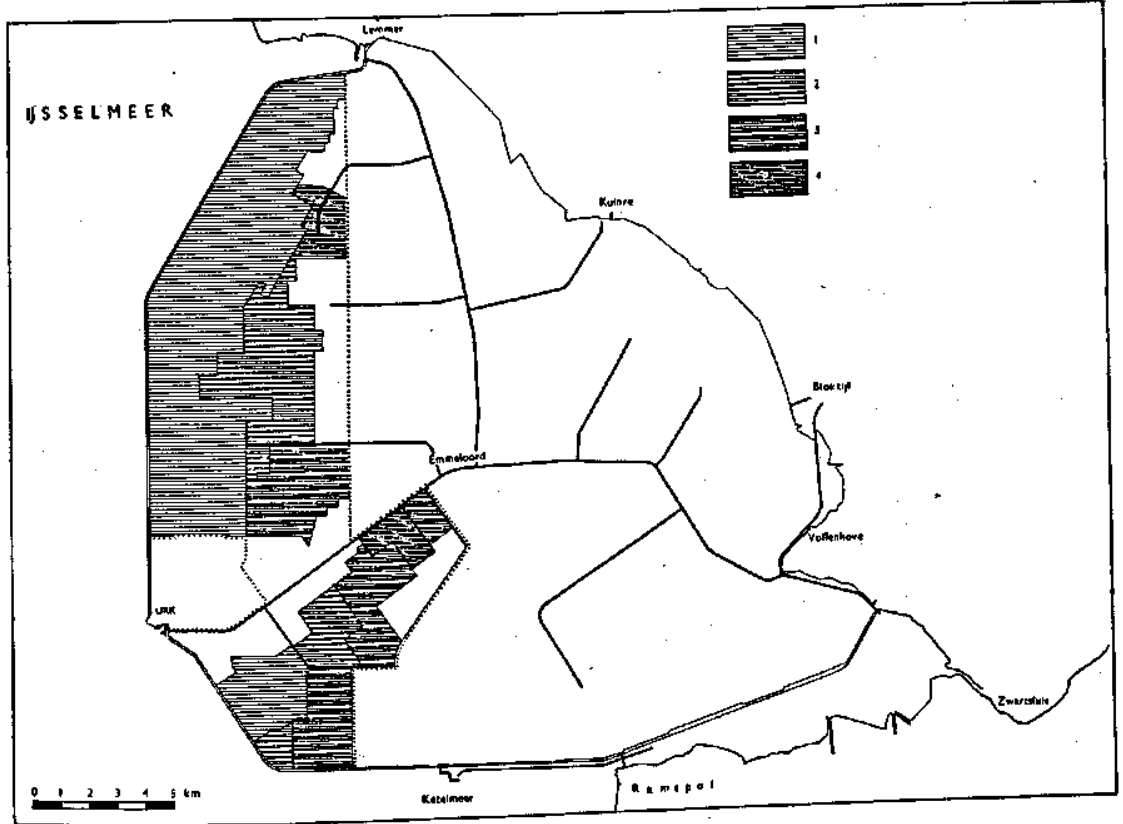

Fig. 18. De noodzaak van de ondergrondbewerking.

The urgency of subsoiling.

1. Urgentie 1.

Urgency 1.

2. Urgentie 2.

Urgency 2.

3. Urgentie 3.

Urgency 3.

4. Urgentie 4 .

Urgency 4.

kelijk zware lagen, zullen deze profielen ook „vanzelf" mettertijd wel beter worden.

De bestendigheid van de losgemaakte structuur

Het is nog niet bekend, na hoeveel jaren de ondergrondbewerking moet worden herhaald. Zonder controle van de beworteling en de ontwatering is de vaststelling hiervan niet mogelijk.

Het kan echter zeer onwaarschijnlijk worden geacht, dat de eenmaal losgemaakte ondergrond in zijn oorspronkelijke ligging zal terugkeren, omdat de omstandigheden waaronder die oorspronkelijke ligging tot stand is gekomen, afwezig zijn.

Factoren welke de losgemaakte toestand kunnen bestendigen, zijn:

1. De ondergrondbewerking zelf. Indien door een geschikte keuze van het werktuig en de omstandigheden, waarbij vooral de droogte van de grond belangrijk is, een maximale verstoring van de oorspronke. 
lijke structuur wordt verkregen, zal het terugkeren in een dichtere ligging meer tijd vorderen.

2. De ontwatering. Indien het ontwateringssysteem (drainage) goed functioneert, is de kans op hoge grondwaterstanden en daardoor vervloeien van de grond (zand) het geringst.

3. De doorworteling. De teelt van veel wortels vormende gewassen helpt mee de losse structuur te bestendigen door de vorming van wortelkanalen. Vooral de teelt van luzerne na de ondergrondbewerking is nuttig.

In 1956 werd de beworteling van enige kavels onderzocht, speciaal met het doel enig inzicht te verkrijgen in de bestendigheid van de door een ondergrondbeworteling verkregen structuur. Daartoe werd de beworteling vergeleken van plaatsen die wel en die niet geondergrond waren, en van plaatsen waar de ondergrondbewerking kortere of langere tijd geleden had plaatsgevonden. Evenals bij de profielvergelijking wordt ook nu de wortelverdeling in de grond beneden de bouwvoor als uitgangspunt genomen.

Tabel 46 geeft een overzicht van deze waarnemingen.

TABEL 46. De wortelverdelingen (\%) op kavels die wel en op kavels die geen ondergrondbewerking hebben gehad, en de totale hoeveelheden wortels in blokken van $10 \times 23 \times 50 \mathrm{~cm}^{3}$.

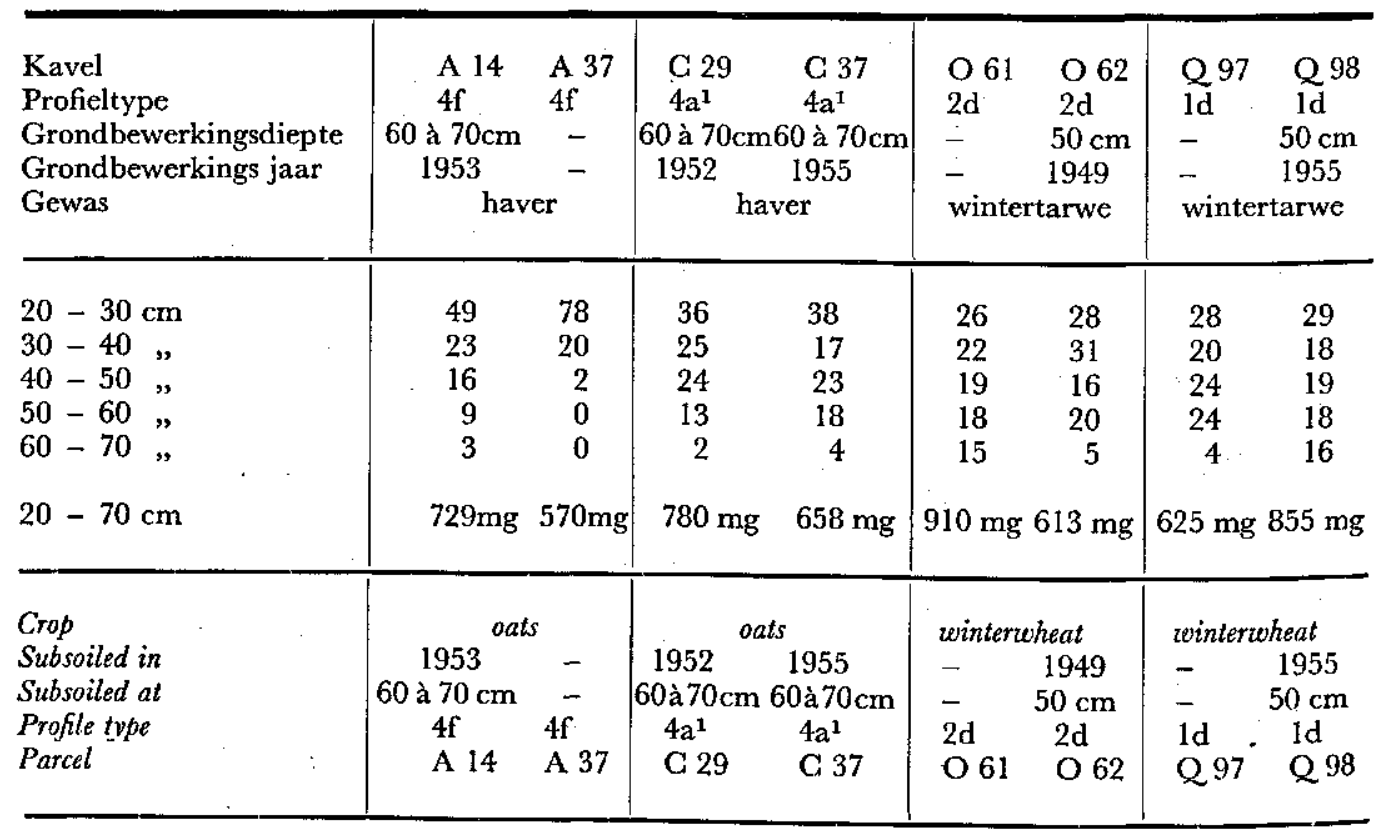

TABLE 46. Proportions between the amounts of roots as percentages of the total amount in the lajer from 20 till $70 \mathrm{~cm}$ below soillevel, and the amount of roots (mg dry matter) in a block $10 \times 23 \times 50 \mathrm{~cm}^{3}$ $(10 \mathrm{~cm}$ length of the croprowe, $23 \mathrm{~cm}$ distance between the rows and $50 \mathrm{~cm}$ depth). 
De kavels A 14 (fig. 48) en A 37 (fig. 58) laten met hun beworteling duidelijk zien, dat drie jaar na de ondergrondbewerking de beworteling van de ondergrond nog aanzienlijk beter is dan zonder ondergrondbewerking.

De wortelverdeling in de profielen van de kavels C 29 en C 37 is gelijk, ondanks een verschil van drie jaar in ondergrondbewerkingstijd. De profielen zijn in de ondergrond iets lichter dan het profiel van kavel B 53 (IV), de ondergrondbewerking is er ook ondieper geweest.

De sloefprofielen van de kavels $O 61$ en $O 62$ zijn op ongeveer gelijke wijze doorworteld. Het niet losgemaakte profiel van kavel $O 61$ is blijkbaar op natuurlijke wijze goed doorwortelbaar geworden. De beworteling gaat zelfs dieper dan op kavel $O 11$, waar de ondergrond minder humeus is dan op de hier genoemde kavels.

Het profiel van de kavels $Q 97$ en $Q 98$ is in de ondergrond zwaarder dan op kavel $S 8$ en lichter dan op kavel $Q 110$. De Zu III-laag, liggende op een lichte zavel $\mathbf{B}$, is goed ontwikkeld, maar niet overmatig dik $( \pm 3 \mathrm{~cm})$. Door de ondergrondbewerking is vermoedelijk wel een betere doorworteling in de onderste laag opgetreden. De aard van de beworteling gaf echter geen aanleiding om de ondergrondbewerking noodzakelijk te achten.

Dat toch op een aantal kavels de ondergrondbewerking werd herhaald, moet niet worden toegeschreven aan een onvoldoende bestendigheid van de lossere grond, maar aan de ongeschikte omstandigheden waaronder de eerste bewerking plaatsvond. In de praktijk werd de verbeterde ontwatering van de geondergronde kavels als het grote voordeel gezien. Dit had tot gevolg, dat een ondergrondbewerking vaak op een natte kavel werd uitgevoerd, in de verwachting dat na de bewerking het land voldoende droog zou worden voor het ploegen. Het effect is dan echter zeer gering, zodat na een of twee jaar de bewerking moet worden herhaald.

De ervaring heeft wel bewezen, dat een ondergrondbewerking in een zo droog mogelijke grond het meeste resultaat geeft. Indien het onafhankelijk van het ploegen mogelijk is, dient het losmaken zo spoedig mogelijk na de oogst te geschieden. 


\section{SAMENVATTING}

\section{Inleiding}

In 1942 viel de Noordoostpolder droog. De bodem was toen nog met water verzadigd, anaeroob en slechts geschikt voor planten die met hun wortels in een zuurstofvrij milieu kunnen leven.

Op het ogenblik van droogvallen begon het rijpingsproces. Dit is het geheel van chemische, physische en biologische processen waardoor de afzettingen een zodanige verandering ondergaan dat een voor de groei van landplanten geschikt bodemmilieu ontstaat. Het wordt ingeleid door het gedeeltelijk verdwijnen van het water, voornamelijk door verdamping. Toetreding van lucht in de bodem wordt dan mogelijk, waarbij de aanvankelijk blauw-zwarte kleur van de bodem verandert in grijs of bruin. ZuUr, Domingo en Van Schreven geven een overzicht van deze rijping.

$\mathrm{Na}$ de eerste ontwatering door middel van greppels wordt de grond in cultuur genomen. De beworteling van de eerste gewassen bereikt aanvankelijk slechts een diepte van enkele decimeters. $\mathrm{Na}$ verloop van tijd met het vorderen van de rijping, kunnen de wortels dieper groeien. Als de grond gedraineerd is en de rijping tot draindiepte is gevorderd $( \pm 100 \mathrm{~cm})$ bereiken de wortels eveneens draindiepte.

Op grond van een onderzoek van VEL.DMAN wordt aangenomen, dat voor een goede vochtvoorziening van de gewassen een doorwortelbare zavellaag van minstens $70 \mathrm{~cm}$ dikte nodig is.

$\mathrm{Bij}$ het bewortelingsonderzoek wordt nagegaan of in de verschillende profielen in de Noordoostpolder deze diepte wordt bereikt en op welke wijze eventueel de bewortelingsdiepte kan worden verbeterd.

Om afwijkingen te kunnen constateren is een juiste kennis van de beworteling der gewassen nodig.

Uitgaande van een maximale bewortelingsdiepte van $\pm 100 \mathrm{~cm}$ in de Noordoostpolder, wordt een beschrijving gegeven van de ontwikkeling der wortelstelsels van de verschillende gewassen in een homogeen zavelprofiel van $100 \mathrm{~cm}$ dikte.

Daarna wordt de invloed van de geologische afzettingen op de beworteling besproken en de beworteling in de profielen zoals die nu in de Noordoostpolder aanwezig zijn.

Er is onderzocht of verbetering van de beworteling door middel van een ondergrondbewerking kan geschieden en welke invloed deze bewerking op de groei der gewassen heeft. 
Tenslotte wordt een overzicht gegeven van de ondergrondbewerking in de Noordoostpolder.

\section{Wijze van onderzoek en enkele resultaten}

Het bewortelingsonderzoek kan gebeuren in daartoe gegraven kuilen of loopgraven, waarbij de wortels in de wandvlakken worden onderzocht, of door het uitgraven van een grondkolom waaruit de grond met behulp van water tussen de wortels wordt weggespoeld. Deze twee methodes kunnen een inzicht geven in de manier waarop de wortels in de grond voorkomen: het wortelbeeld.

Indien uitsluitend de wortelhoeveelheid behoeft te worden bepaald, is het gebruik van grondboren eenvoudiger. Door uitspoelen van de grondmonsters over zeven kunnen de wortels worden verzameld en gewogen. De nauwkeurigheid van deze bepalingen is niet groot, zodat het gewenst is een groot aantal herhalingen te verrichten. Door mechanisatie, zowel van het nemen der boormonsters als van het uitspoelen ervan, is het mogelijk het anders nogal omvangrijke handwerk te beperken.

Bij vergelijking van de wortelhoeveelheden verkregen uit grondkolommen en boormonsters blijkt dat er geen overeenstemming bestaat tussen de resultaten van deze twee methodes. Dit wordt veroorzaakt door de ongelijkmatige verdeling van de wortels in de grond.

Van de wintertarwe is daarom onderzocht hoe de verdeling der wortels is van rij tot rij. Een naaldenplank werd hiertoe dwars over vier rijen in de grond gedrukt en daarna in plakjes van $1 \mathrm{~cm}$ dikte verdeeld (fig. 1, 2 en tabel 1). Het blijkt hierbij dat de ongelijkmatigheid beperkt is tot het bovenste gedeelte van de bouwvoor.

Voor de berekening van de juiste hoeveelheid wortels in de bouwvoor moet dus met deze verdeling rekening worden gehouden. Voor de ondergrond kan worden volstaan met een omrekening naar de verhouding der volumina. Het is te verwachten dat ook voor andere gewassen dan wintertarwe een dergelijke systematische onregelmatigheid zal bestaan.

Het bewaren van wortels of grondmonsters in $4 \%$ formaline had geen invloed op de wortelhoeveelheden.

Het spoelen van grondmonsters over zeven met maaswijdten van $1 \mathrm{~mm}$ en $0.25 \mathrm{~mm}$ geeft een hoger wortelgewicht dan bij het spoelen van de naaldenplanken werd verkregen. Deze grotere wortelhoeveelheid wordt toegeschreven aan het achterblijven van vezelig materiaal van plantaardige herkomst, dat niet van de wortels is te scheiden.

II. De ontwikkeling van het wortelstelsel in een homogeen zavelprofiel

De beworteling in een homogeen zavelprofiel van $100 \mathrm{~cm}$ diepte wordt als grondslag genomen voor de beoordeling van de bewortelingen in de verschillende profielen in de Noordoostpolder.

De ontwikkeling van de boven- en ondergrondse delen der planten 
van kieming tot oogst is schematisch weergegeven voor wintertarwe (fig. 3), zomergerst (tig. 8), winterkoolzaad (fig. 9) en suikerbieten (fig. 10).

$\mathrm{Bij}$ de granen worden onderscheiden:

le. de kiemwortels, welke uit het zaad ontspringen, omlaag groeien en de grootste diepte bereiken;

2e. de kroonwortels, welke aan de bäsis van de stengels ontspringen en vooral in de bouwvoor hun sterkste ontwikkeling hebben, maar ook in de diepte groeien;

3e. de zodelaag, welke dicht onder de oppervlakte wordt gevormd door de zijwortels van de kroonwortels.

De uitbreiding van het wortelstelsel gaat aanvankelijk vlugger dan het bovengrondse gedeelte. Omstreeks de tijd dat de planten gaan schieten bereikt het wortelstelsel de grootste omvang, daarna blijft het enige tijd ongeveer gelijk en neemt tegen de rijping af.

Dit blijkt duidelijk uit de periodieke bemonstering van wintertarwe in 1956 en 1957, waarvan de resultaten zijn opgenomen in de tabellen 4 en 5 en in de figuren 4 en 6.

$\mathrm{Bij}$ de tweezaadlobbigen worden onderscheiden:

le. de penwortel;

2e. de zijwortels.

De vorm en aard van hoofd- en zijwortels is afhankelijk zowel van het gewas als van de grond. Gewassen als luzerne en suikerbieten hebben een zeer duidelijke penwortel met fijne zijwortels; bij de erwten is het verschil tussen hoofd- en zijwortels geringer.

Alle gewassen kunnen met hun wortels in twee tot drie maanden een diepte van $100 \mathrm{~cm}$ bereiken. De grootste uitbreiding van het wortelstelsel valt ongeveer samen met het begin van de bloei. Een uitzondering hierop vormen o.a. de gewassen, die meermalen worden geoogst en waarvan de wortelgroei blijft doorgaan, bijvoorbeeld luzerne.

III. De ontwikkeling van het wortelstelsel in verschillende grondsoorten

Deze bestaan geheel of gedeeltelijk uit een andere grondsoort dan zavel, of hebben een van de mariene zavel afwijkende samenstelling. Een onvoldoende rijping kan ook als een afwijking van het homogene zavelprofiel van hoofdstuk II worden beschouwd.

Achtereenvolgens wordt de betekenis van de rijping en de granulaire samenstelling van de wortelgroei behandeld.

De aëratie

Dit is het onderdeel van de rijping dat betrekking heeft op de Iuchttoetreding in de bodem. 
Uiterlijk is dit kenbaar door het droger worden van de bodem en eer kleurverandering van donkerblauw naar grijs of bruin.

De kleurverandering is het gevolg van een oxydatieproces dat mogelijk wordt nadat door het verdwijnen van water uit de grond, lucht kan toetreden. De diepte tot waar de lucht is toegetreden is merkbaar aan de kleurverandering.

De bewortelingsdiepte van de gewassen wordt bepaald door de aëratiediepte. In de blauwe, ongeaëreerde grond worden slechts zelden wortels van gewassen aangetroffen, rietwortels daarentegen in zeer grote hoeveelheden.

\section{De granulaire samenstelling}

De bespreking van de invloed van de granulaire samenstelling op de beworteling geschiedt aan de hand van de geologische opbouw van de Noordoostpolder zoals deze door WigGERs is beschreven.

Het keileem, de glaciale zanden en dekzanden worden niet doorworteld. De zanden zijn wel geaëreerd maar niet toegankelijk voor wortels. Voor zover podsol-profielen aanwezig zijn worden alleen de A-horizonten doorworteld.

Het veen, voornamelijk riet-zeggeveen, wordt in geaëreerde toestand goed doorworteld.

De oude zeeklei is goed toegankelijk voor zover zij bij haar ontstaan doorworteld is geweest, zoals de kwelderklei. Deze kwelderklei is echter vaak zeer zuur en is dan niet toegankelijk voor wortels.

De detritus-gyttja is in geaëreerde toestand doorwortelbaar indien zij een kruimelige massa vormt bij de verwering. Sommige detritusafzettingen vallen bij uitdroging echter uiteen in scherpe kleine brokjes, die ontoegankelijk, zijn.

De sloefafzettingen zijn meestal fijn gelaagde, fijnzandige lichte zavels met een grote variatie in humusgehalte. Het lutumgehalte in de sloef is naar verhouding lager dan in zavel.

$\mathrm{Bij}$ het waterverlies tijdens de indroging onderscheidt de sloef zich van de zavel door de geringere en soms achterwege blijvende scheurvorming. De aëratie verloopt langzaam. Meestal is deze afzetting slecht toegankelijk voor de wortels. De structuur, afwisselend zand- en slib- of humuslaagjes, speelt hierbij vermoedelijk een rol.

De Zus, Zu IV en Zu II zijn goed doorwortelbare zavels.

$\mathrm{De} \mathrm{Zu}$ III, gevormd door een meer of minder dik zandlaagje, vormt over het algemeen geen belemmering voor de wortels, indien het niet dikker is dan 3 à $5 \mathrm{~cm}$ en op een goed doorwortelbare laag ligt. Boven een slecht toegankelijke sloeflaag is een dikte van $2 \mathrm{~cm}$ reeds bezwaarlijk voor de wortels.

De samenstelling van de bouwvoor is van geringe betekenis voor de doorworteling omdat deze laag door de bewerking steeds in een gunstige toestand kan worden gebracht.

In de Noordoostpolder komen op enkele plaatsen dikke zandafzettin- 
gen voor. Het Urk-, Nagele- en Kuinrezand zijn zeer slecht doorworteld, het Ramspol-, Espel- en Blokzijlzand zijn matig toegankelijk voor wortels. Voor zover de wortels in het zand groeien, zijn zij in de regel dikker dan in de zavel en vaak kronkelig. In het niet doorwortelbare zand eindigen de wortels met verdikte worteltoppen (fig. 34, 35 en 36).

In sommige afzettingen komen veel schelpen voor, welke, indien zij in in grote getallen aanwezig zijn, de doorworteling van onderliggende lagen belemmeren.

\section{Mogelijke oorzaken van beperkte of ontbrekende wortelgroei}

Een verklaring kan gezocht worden in:

le. een onvoldoende vochtvoorziening.

2e. een onvoldoende voedselvoorziening.

3e. te dichte pakking van de grond.

4e. een onvoldoende zuurstofvoorziening.

5e. andere factoren.

Een onvoldoende vocht- en voedselvoorziening van de wortels komt niet in aanmerking, omdat deze in losgemaakte zandlagen, waarin de wortels wel groeien, gelijk of minder goed zullen zijn.

Op grond van waarnemingen, Wiersum, VeiHMEYer en Hendrickson, BERTRAND en KoHNKe, moet worden aangenomen dat de wortels een minimale poriënwijdte nodig hebben om te kunnen groeien. Daar de wortels een zekere druk kunnen uitoefenen, kunnen zij zich tussen bodemdeeltjes wringen door deze opzij te drukken. De mogelijkheid om zich ruimte te verschaffen hangt af van de vervormbaarheid van de bodemstructuur. Deze vervormbaarheid wordt onder meer beinvloed door de inwendige wrijving en de pakking. Uit de granulaire samenstelling en de doorwortelbaarheid van de zandsoorten (tabel 6) volgt dat een kleine hoeveelheid Jutum $(3-5 \%)$ een gunstige invloed heeft op de doorworteling. Misschien wordt hierdoor de vervormbaarheid gunstig beïnvloed.

De voor de wortels onmisbare zuurstofvoorziening wordt beïnvloed door de structuur, namelijk in die zin, dat de diffusiesnelheid van de zuurstof volgens BERTRAND en KoHNKe en WEsseLing afhankelijk is van. het luchtgehalte van de grond.

Daar een dichte pakking en een laag luchtgehalte samengaan, kan een beperkte wortelgroei zowel aan de ene als an de andere oorzaak worden toegeschreven.

GiLl en Miller vonden dat de wortels voor het overwinnen van een grote druk een betere zuurstofvoorziening nodig hebben dan voor het overwinnen van een lage druk. Dit zou er op kunnen wijzen dat een dichte pakking niet ongunstig is als gevolg van de uitgeoefende mechanische weerstand, maar als gevolg van de uit de dichte pakking voortkomende te geringe zuurstofaanvoer.

Van de verschillende zandsoorten is de vorm geschat (volgens RITTEN- 
House). Tabel 7 geeft een overzicht van de bevindingen, welke ten aanzien van de bolvormigheid geen verschil tussen de zandsoorten te voorschijn bracht. De zandsoorten van lokale herkomst, Urk, pleistoceen-, Nagele- en Kuinrezand zijn min of meer afgerond, de andere zanden zijn scherphoekig. De invloed hiervan op de vervormbaarheid van de structuur is niet aan te geven.

\section{De beworteling in verschillende bodemprofielen}

In 1955 en 1956 werd de beworteling in verschillende profielen onderzocht. Aangenomen mag worden dat de aëratie, voorzover deze aanwijsbaar is door het verdwijnen van de blauwe kleur uit de grond, geen verdere veranderingen zal ondergaan, omdat zij door de grondwaterstand wordt bepaald. De beworteling van een profiel wordt dan bepaald door de aard van de samenstellende grondlagen. Bij het bewortelingsonderzoek van de profielen kan dan blijken in hoeverre zij overeenkomen of afwijken van het in hoofdstuk II behandelde zavelprofiel. Mochten er nog afwijkingen in de beworteling voorkomen, dan kunnen deze zo nodig en zo mogelijk door een bewerking worden verbeterd. Anderzijds bestaat de kans, dat profielen, welke reeds plaatselijk door een bewerking waren verbeterd, ook uit zichzelf op den duur goed doorwortelbaar waren geworden. Zodoende worden aanwijzingen verkregen voor eventuele bewerkingen van overeenkomstige profielen in de nog te ontginnen polders in het IJsselmeer.

De profielen werden ingedeeld volgens het schema op bladzijde 70 en 71. Deze indeling berust op het voorkomen in de boven- en ondergrond van zware of lichte zavel, zand of veen.

Daar de bouwvoor in het algemeen geen moeilijkheden voor de beworteling oplevert, werd de verdeling van de wortels in de laag van 20-70 cm diepte onder de oppervlakte als maatstaf voor de beworteling genomen. Met de beschikbare naaldenplanken van $35 \times 70 \mathrm{~cm}$ werden de profielen bemonsterd. Zo mogelijk werd het gewas wintertarwe onderzocht, in de plaats daarvan ook zomertarwe of haver. Tabel 8 geeft een overzicht van de wortelhoeveelheden en de verdeling van deze drie granen in verschillende profielen. Alleen haver vertoont afwijkingen, welke aan rasinvloeden kunnen worden toegeschreven.

De tabellen 9, 10,11, 12, 13 en 14 geven de verdeling der wortels aan in de verschillende profielen. De meeste profielen zijn goed doorwortelbaar, hetzij van nature, hetzij nadat zij een ondergrondbewerking hebben ondergaan (tabel 46).

De sloefprofielen ondergingen een natuurlijke verbetering, zodat de indertijd toegepaste ondergrondbewerking slechts een versnelling van de rijping heeft betekend.

Uit de aard van de beworteling kan nièt zonder meer worden afgeleid of zij voldoende is voor de planten. De mogelijkheid om voedingsstoffen en water uit de grond op te nemen is belangrijker dan de diepte waaruit deze stoffen worden gehaald. 


\section{De ondergrondbewerkingsproefvelden}

Ondergrondbewerkingen zijn toegepast, omdat is gebleken dat bepaalde grondsoorten na losmaken toegankelijk werden voor wortels. Het doorwortelbare bodemvolume werd daardoor groter.

Dit kan vooral voor de vochtvoorziening van een gewas belangrijk zijn.

Andere voordelen zijn een versnelde rijping en een verbeterde ontwatering.

De ondergrondbewerkingen geschiedden met:

le. ploegen voorzien van ondergrondbrekers achter de risters (fig. 11).

2e. werktuigen welke de grond op grote diepte kunnen losmaken (fig. 12 en 13$)$.

Met het tweede soort werktuigen, bestaande uit een frame, waaraan verticaal lange messen zijn bevestigd, onderaan voorzien van een brede voet, werden trekkrachtproeven genomen.

De benodigde trekkracht en de doorsneden van de losgemaakte grond bij verschillende werkdiepten en breedten van de voet staan vermeld in tabel 15 en de figuren 14 en 15 . Hieruit blijkt dat het verticale mes het grootste deel van de trekkracht vraagt, en dat de werkdiepte en breedte van de voet de hoeveelheid losgemaakte grond bepalen.

Ondergrondbewerkingsproefvelden werden aangelegd op plaatsen waar

1. sloef in de ondergrond voorkomt,

2. zand in de ondergrond voorkomt,

3. het gehele profiel uit zand of lichte zavel bestaat.

De proefvelden op zavel met sloef in de ondergrond ( $Q 65$ en $O 98$ ) gaven een verbetering van de aëratie te zien en een betere, diepere doorworteling. Ook de ontwateringstoestand werd beter. Belangrijke opbrengstverhogingen werden niet bereikt.

Op de proefvelden op zavel met een zandondergrond (M 128) werd een diepere beworteling verkregen, waardoor een betere vochtvoorziening tot stand kwam welke resulteerde in een hogere opbrengst. Deze bleef echter lager dan de normale opbrengst.

Op de proefvelden met zand en lichte zavel in het profiel (B 68, C 62 en D 24) werd een betere ontwatering verkregen (tabel 35) en een diepere beworteling. Ofschoon een geringe opbrengstverhoging tot stand kwam was deze nauwelijks belangrijk genoeg om de ondergrondbewerking te rechtvaardigen. In een zeer droge tijd zou de opbrengstverhoging vermoedelijk wel van betekenis zijn geweest.

De betere ontwateringstoestand is wel van belang, omdat daarbij de bewerkbaarheid van de bouwvoor zich over een langere tijd uitstrekt.

$\mathrm{Bij}$ suikerbieten werd een verbetering van de bietvorm geconstateerd.

De machinale oogst van hakvruchten gaat beter en veroorzaakt een geringer structuurbederf van de bouwvoor. 
VI. De ondergrondbewerking in de Noordoostpolder

Voor het deel van de Noordoostpolder, liggend ten westen van de noord-zuidlijn door Lemmer, werd onderzocht waar in de profielen voor de beworteling storende lagen voorkomen. De storende lagen bestaan uit zand, zandige sloef, schelplagen en meer of minder dikke zandlaagjes (Zu III).

Op een drietal kaarten werd aangegeven welke lagen storend zijn voor de beworteling en tot welke diepte de profielen dienden te worden losgemaakt en op welke plaatsen de grootste noodzaak voor het losmaken.

Op een aantal kavels werd in 1956 onderzocht of de ondergrondbewerking een verbetering tot gevolg had en hoe lang deze verbetering stand houdt.

Uit het overzicht dat tabel 46 van dit onderzoek geeft blijkt dat indien de ondergrondbewerking onder gunstige, dat wil zeggen droge, omstandigheden is uitgevoerd, deze na drie jaar nog goed merkbaar is. De doorworteling van de losgemaakte grond zal kunnen bijdragen tot het behoud van de lossere structuur. 


\section{SUMMARY}

Root studies and subsoiling in the North-Eastern Polder

\section{Introduction}

The North-Eastern polder was pumped dry in 1942. The soil still is saturated with water, anaerobic and suitable only for plants capable of living with their roots in an environment containing no free oxygen.

Immediately after the water has receded, the process of maturing commences. By this is meant the complex of chemical, physical and biological processes by which the deposits undergo such changes that a soil results in which land plants can grow. These processes are initiated by the partial disappearance of the water, chiefly by evaporation. This enables air to enter the soil, whose initial blue-black colour changes to grey or brown. ZuUr, Domingo and Van Schreven describe the various stages of this maturing process.

After initial drainage by means of open drains the soil is cultivated. At the start, the roots of the first crops do not penetrate beyond a few decimetres. As the maturing process advances, however, the roots can grow deeper. When the soil has been tile-drained and the maturing has progressed to the depth of the tile-drains (about $100 \mathrm{~cm}$ ), the roots also reach this depth.

On the basis of an investigation conducted by VELDMAN it is assumed that an adequate moisture supply to the crops requires a loamy layer at least $70 \mathrm{~cm}$ thick which is penetrable by roots.

In the present root studies investigations are conducted to find out whether in the various soil profiles of the Nort-Eastern polder this depth is reached, and in what way the depth of root penetration may possibly be increased.

Irregularities can be traced only if the root habits of the crops are accurately known.

Starting from a maximum root penetration of about $100 \mathrm{~cm}$ in the North-Eastern polder, a description is given of the development of the root systems of the various crops in a homogeneous loam soil profile of $100 \mathrm{~cm}$ depth.

The influence of the geological deposits on the root formation, and the root formation in the profiles as they are at present to be found in the North-Eastern polder are discussed subsequently.

Investigations were made to find out whether root formation may be 
improved by subsoiling, and whether this treatment has an effect on the growth of the crops.

Finally a description is given of the subsoiling operations carried out in the North-Eastern polder.

\section{Method of investigation and some results}

Root studies can be made either by digging pits or trenches and examining the roots in the walls thus exposed, or by digging out a block of soil and washing out the soil from between the roots. Either method can provide an insight into the manner in which the roots are present in the soil: the root habit.

If only the quantity of roots has to be determined, it is simpler to use soil augers. After rinsing out the soil samples over sieves, the roots can be collected and weighed. The accuracy of these determinations is not great, so that a large number of replications is required. By mechanizing the sampling as well as the washing out of the samples the otherwise large amount of labour may be reduced.

When the quantities of roots obtained from soil blocks and from the samples collected bij means of augers are compared, it is found that the results of the two methods do not agree. This is due to the irregular distribution of the roots in the soil.

In view of this, the distribution of the roots of winter wheat was investigated row by row. This was done by means of a pin-board which was pressed into the soil across four rows, and subsequently divided into sections of $1 \mathrm{~cm}$ thick (Fig. 1 and 2 and Table 1). The irregularity is found to be confined to the upper part of the topsoil.

If, therefore, the correct quantity of roots in the topsoil has to be determined, this distribution has to be taken into account. With respect to the subsoil a conversion based on the ratio of the volumes will do. It is to be expected that crops other than winter wheat will show a similar systematic irregularity.

Preservation of roots or soil samples in a 4 per cent solution of formaldehyde did not affect the quantities of roots.

The weight of the roots found after washing out soil samples over $1 \mathrm{~mm}$ and $0.25 \mathrm{~mm}$ sieves is higher than that obtained after rinsing out the soil from the pin-boards. The larger quantity of roots is attributed to fibrous matter of vegetable origin being left behind, which cannot be separated from the roots.

\section{Development of the root system in a homogeneous loam soil profile}

The root formation in a homogeneous loam soil profile of $100 \mathrm{~cm}$ in depth is taken as the standard for the assessment of the root systems found in the various profiles in the North-Eastern polder.

The development of the above-ground and underground parts of the plants from germination to harvesting has been represented diagram- 
matically for winter wheat (Fig. 3), spring barley (Fig. 8), winter swede rape (Fig. 9) and sugar beet (Fig. 10). ${ }^{1}$ )

In cereals the following types of roots are:

1. the primary roots, which develop from the seed, grow downwards and reach the greatest depth;

2. the secondary roots, which arise from the bases of the stems and develop most profusely in the topsoil, although they also grow downwards;

3. the rootsystem, which is formed closely below the soil surface and is made up of the branches of the secondary roots.

At first the extension of the root system takes place more rapidly than that of the parts of the plant above ground. The root system reaches its maximum development about the time when the plants are forming ears; after that it remains about the same for some time, and decreases during maturing.

This is clearly apparent from the periodical sampling of winter wheat carried out in 1956 and 1957 , the results of which are shown in Tables 4 and 5 and in the Figures 4 and 6.

In the dicotyledons are distinguished

1. the taproot;

2. its branches.

The shape and nature of the taproot and its branches depend on the crop as well as on the soil. Crops such as lucerne and sugar beet have a very distinct taproot with fine branches; in peas the difference between taproot and branches is less marked.

The roots of all crops may in from two to three months reach a depth of $100 \mathrm{~cm}$. The maximum development of the root system about coincides with the beginning of the blossoming. Exceptions to this rule include those crops which are harvested more than once, and whose roots continue to grow, like lucerne.

IV. The development of the root system in the various sediments

These sediments are partly made of a soil other than loam, or show a composition which differs from that of the marine loam soil. The influence of insufficient maturing of the soil in the root growth is also considered.

The significance of maturing and of texture to root development are successively discussed.

\section{Aeration}

By this is meant that part of the maturing process which concerns the movement of air into the soil. Outwardly it manifests itself by the drying up of the soil and by a change in colour from dark blue to grey or brown.

The change in colour is due to an oxydation process which sets in as soon as the movement of water from the soil makes it possible for air to enter it. The depth to which the air has penetrated is apparent from the change in colour.

1) The text in these figures is explained in the word-list on page 159. 
The depth of root penetration of the crops is determined by the depth of aeration. In the blue unaerated soil, roots of crops are only rarely found; roots of reed, on the other hand, are encountered in very large quantities.

\section{Texture}

The discussion of the effect of the texture on root penetration is based on the geological formation of the North-Eastern polder as described by WIGGERS.

In boulder clay, glacial sands and cover sand no root formation takes place. The sands are indeed aerated, but not accessible to roots. In so far as podsol profiles are present, it is only in the A-horizons that roots develop.

When aerated, the peat soils, chiefly reed-sedge peat, show an adequate root formation.

Root penetration is satisfactory in the old marine clay, in so far as it contained roots at the time of its formation, as in the case of the clay found in the saltings. However, this clay is often highly acid and in that condition can not be penetrated by roots.

If the detritus-gyttja forms a crumbly mass on weathering, root penetration is possible. However, some detritus sediments on drying break up into sharp small lumps, which are impenetrable.

The silt sediments are as a rule finely stratified fine sandy silt loams with a greatly varying humus content. The clay content in the silt is relatively lower than in the loam.

During drying up the silt deposits differ from the loam soils by forming fewer cracks, or sometimes none at all. Aeration proceeds slowly. Root penetration is usually poor in this sediment. Its structure of alternating layers of sand and clay or humus would seem to be partly responsible for this.

The Zus, Zu IV and Zu II are loam soils in which root penetration is good.

The $\mathrm{Zu} \mathrm{III,} \mathrm{formed} \mathrm{by} \mathrm{a} \mathrm{layer} \mathrm{of} \mathrm{sand} \mathrm{which} \mathrm{varies} \mathrm{in} \mathrm{thickness,} \mathrm{does}$ not as a rule impede root penetration, if it is not thicker than from 3 to $5 \mathrm{~cm}$ and is underlaid by a layer which can easily be penetrated by roots. If, however, it overlies a layer of silt of poor penetrability, it constitutes a major obstacle to root penetration if it is not more than $2 \mathrm{~cm}$ thick.

The composition of the topsoil is of little importance as far as root penetration is concerned, because this layer can always be put into a favourable condition by tillage.

In the North-Eastern polder there are a few thick sand deposits. Those found near Urk, Nagele and Kuinre show very poor root penetration; those found near Ramspol, Espel and Blokzijl show moderate penetration by roots. In so far as roots do grow in the sand, they are usually thicker than those growing in loamy soils, and often tortuous. In the impenetrable sand they end with thickened root tips (fig. 34, 35 and 36). 
Some sediments contain large quantities of shells, which, if too numerous, hamper root penetration into the underlying layers.

Possible causes of the poor development or absence of roots

The causes may be:

1. an inadequate supply of moisture;

2. an inadequate supply of nutrients;

3. too great a compactness of the soil;

4. an inadequate supply of oxygen;

5. other factors.

Inadequate supplies of moisture and nutrients need not be considered, since these conditions will be the same or worse in loosened sandy layers in which roots do grow.

Due to observations made by Wiersum, VexhMeyer and Hendrickson, BerTRAND and KoHNKe it has to be assumed that roots need a minimum pore space to be enabled to grow. Since roots are capable of exerting a certain pressure, they can wedge themselves in between soil particles by pushing them aside. The possibility of making room for themselves depends on the degree in which a soil structure allows a rearrangement of the soil particles. Among the factors determining this plasticity are internal friction and compactness. From the texture and the penetrability to roots of the various types of sand (Table 6) it is apparent that a small quantity of clay $(3 \%$ to $5 \%$ ) has a favourable effect on root penetration. It is possible that the plasticity is favourably affected by it.

The supply of oxygen, indispensable to the roots, is influenced by the texture since according to BERTRAND and KOHNKE and WEsseling the rate of diffusion of the oxygen depends on the air content of the soil.

Since a high degree of compactness is accompanied by a low air content, a poor root development may be attributed to either cause.

GILL and MiLLer found that roots need a better supply of oxygen to overcome a high than a low pressure. This might point to the conclusion that a dense packing is unfavourable, not as a result of the mechanical resistance offered, but as a consequence of the-insufficient oxygen supply due to the high degree of compactness.

Of the various types of sand the shape was estimated (according to Rittenhouse. Table 7 shows the results, from which no difference in sphericity between the types of sand is apparent. The types of sand of local origin, viz, Urk, pleistocene, Nagele and Kuinre sand, are more or less rounded, whereas the other sands are sharply angled.

The influence of this on the plasticity of the structure cannot be indicated.

V. Root formation in various soil profiles

In 1955 and 1956 investigations were made on the root formation in various profiles. It may be assumed that aeration, in so far as apparent from the vanishing of the blue colour from the soil, will not undergo 
any further changes, since it is determined by the water table. Root formation in a profile is determined by the nature of the component soil layers.

In the course of the investigations on root development in the profiles it will become apparent in how far they agree with or differ from the loam soil profile dealt with in Chapter III. If irregularities as to root formation are found to occur, they may, if necessary and if possible, be improved by tillage. On the other hand there is the possibility that profiles, which had already been locally improved by tillage, also eventually show satisfactory penetration by roots if they had been left to themselves. In this way indications are obtained for the possible tillage of similar profiles in future Lake IJssel polders.

The profiles were classified according to the plan on page 70 en 71 . This classification is based on the presence in the topsoil and subsoil of silty clay loam or silt loam, sand or peat.

In view of the fact that the topsoil does not as a rule present difficulties as to root development, the distribution of the roots in the layer from $20 \mathrm{~cm}$ to $70 \mathrm{~cm}$ below the ground level was taken as a measure for root formation. The profiles were sampled by means of pin-boards. The crop investigated was winter wheat; if this was not possible, spring wheat or oats were studied instead. Table 8 shows the quantities of roots and their distribution for these three cereals in various profiles. Oats only show irregularities which are attributable to varietal influences.

Most of the profiles show good root penetration, either naturally, or after having been subsoiled (Table 46 ).

The silt profiles underwent a natural improvement, so that the subsoiling at an early stage merely brought about a speeding up of the maturing process.

From the nature of the root development as such it is impossible to conclude whether or not it is adequate for the crops concerned. The possibility of absorbing nutrients and water from the soil is more important than the depth from which these substances are taken.

\section{Subsoiling}

Subsoiling was practised, because it was found that certain types of soil become penetrable to roots after having been loosened. This results in an increased soil depth in which root penetration is possible. This may be of importance particularlr with respect to the moisture supply of a crop.

Other advantages are an accelerated maturing and improved drainage.

Subsoiling was done by means of:

1. ploughs provided with panbreakers behind the mouldboards (Fig. 11).

2. machines by means of which the soil may be loosened at a great depth (Fig. 12 and 13).

With the second type of machine, consisting of a frame from which are vertically suspended long blades with chisels in the bottom, drawbar pull measurements were made. 
The drawbar pull and the shattering of the soil at various working depths and breadths of the chisel are shown in Table 15 and in the Fig. 14 and 15. From these data it becomes apparent that the vertical blade requires the greater part of the drawbar pull, and that the working depth and the width of the chisels determine the amount of soil loosened.

Subsoiling trial plots were laid out in areas where

1. silt is present in the subsoil;

2. sand is found in the subsoil;

3. the entire profile is made up of sand or silt loam.

The trial plots on loam underlaid by silt showed an improved aeration and a better and deeper root penetration. Drainage also improved. No marked increases in yield were obtained.

On the trial plots on Ioam underlaid by sand root penetration became deeper, resulting in a better moisture supply, which in its turn led to an increased yield. It nevertheless remained below the normal yield.

On the trial plots with profiles containing sand and silt loam drainage improved (Table 35) and root penetration became deeper. Although a slight increase in yield was obtained, it was hardly substantial enough to justify subsoiling. In a period of extreme drought the increase in yield might have been considerable.

Improved drainage is of importance, because the topsoil continues to be workable for a longer period of time afterwards.

Machine-harvesting of root crops becomes easier and is less detrimental to the structure of the topsoil.

\section{Subsoiling in-the North-Eastern polder}

Soil profiles in that part of the North-Eastern polder which lies west of the north-south line through Lemmer were examined for layers which interfered with root penetration. The layers concerned consist of sand, sandy silt, shells and layers of sand of varying thickness (Zu III).

On three maps it was indicated which layers hamper root penetration, and to which depth the profiles whould be loosened, whereas in addition were indicated the areas most badly in need of subsoiling (Fig. 16, 17, 18).

In a number of parcels investigations were made in 1956 to find out whether subsoiling brought about improvements, and for how long these improvements continued to be noticeable.

From the data about these investigations shown in Table 46 it will be seen, that subsoiling practised under favourable, i.e. dry, conditions, still is quite noticeable after three years. Root penetration of the loosened soil may help to preserve the looser structure. 
Explanation of the terms from the figures 3, 8, 9 and 10.

Zaai

Opkomst

Ontwikkeling van de eerste spruit

Winterrust

Uitstoelen

Schieten

Halmhoogte

Bladhoogte

Afstervend blạd

Vergelend blad

Aar verschijnt

Bloei

Vruchtgroei

Rijping

Oogst

\section{Maaiveld \\ Zaaibed. \\ Bouwvoor \\ Draindiepte}

Kiem wortels

Kiem zijwortels

Kroon wortels

Kroon zijwortels

Steunwortels

Manchetvorming

Totale (tevens penwortel) diepte

Zode vorming

Zode afsterving
Sowing

Germination

Development of the first tiller

Winter dormancy

Tillering

Stem extension

Height of the stems

Height of the leaves

Dying leaves

Yellowing leaves

Heading

Blossoming

Ripening

Ripening

Harvest

Soil surface

Seed bed

Top soil

Depth of the draintiles

Primary roots

Branches of the primary roots

Secondary roots

Branches of the secondary roots

Secondary roots supporting the stem

Branching profusely of the roots following wintering

Depth of the (tap) roots

Ramifiyng of the roots near the surface

Decaying of the roots near the surface 
Explanation of the terms of fig. 7

Korrel

Spruiten

Wortels

Kleine spruiten
Seed

Tillers

Roots

Small tillers, disappearing during heading

Explanation of the terms of fig. 14 and 15

Voetbreedte

Voetdiepte

Width of the chisel

Trekkracht

Working depth of the chisel

Drawbar pull 
De betekenis van de GEBRUKTE SYMBOLEN voor aanduiding van de grondsoorten in de Noordoostpolder.

The meaning of the used symbols, indicating the soil varieties in the North-Eastern polder.

\begin{tabular}{|c|c|c|c|}
\hline $\begin{array}{c}\text { Symbool } \\
\text { Symbol }\end{array}$ & $\begin{array}{l}\text { Grondsoort } \\
\text { Soil variety }\end{array}$ & $\begin{array}{l}\text { g lutum/ } \\
100 \mathrm{~g} \text { droge grond } \\
g \text { clay/ } \\
100 \mathrm{~g} \text { dry soil }\end{array}$ & $\begin{array}{l}\text { afslibbaar } \\
g \text { fine silt }\end{array}$ \\
\hline $\begin{array}{l}0 \\
1 \\
2 \\
3 \\
4 \\
5 \\
6 \\
7 \\
8\end{array}$ & $\begin{array}{l}\text { kleiarm zand A } \\
\text { sand } \\
\text { kleiarm zand B } \\
\text { sand } \\
\text { kleihoudend zand A } \\
\text { (loamy) sand to silt (loam) } \\
\text { kleihoudend zand B } \\
\text { loamy sand } \\
\text { lichte zavel A } \\
\text { sandy loam - silt loam } \\
\text { lichte zavel B } \\
\text { sandy loam - silt loam } \\
\text { zware zavel A } \\
\text { loam } \\
\text { zware zavel B } \\
\text { loam } \\
\text { klei A }\end{array}$ & $\begin{array}{l}0-1.5 \\
1.5-3 \\
3-5 \\
5-8 \\
5-8 \\
8-12 \\
12-17 \\
17-25 \\
25-35\end{array}$ & $\begin{array}{l}0-10 \\
10-20 \\
20-40 \\
40-100\end{array}$ \\
\hline $\begin{array}{c}\text { Symbool } \\
\text { Symbol }\end{array}$ & $\begin{array}{l}\text { Zandsoort } \\
\text { Sand variety }\end{array}$ & $\begin{array}{c}\text { U-cijfer } \\
\text { zandfractie } \\
\text { Specific surface } \\
\text { sand fraction }\end{array}$ & . \\
\hline $\begin{array}{l}\mathrm{b} \\
\mathrm{c} \\
\mathrm{d} \\
\mathrm{e} \\
\mathrm{f}\end{array}$ & $\begin{array}{l}\text { grof zand } \\
\text { coarse sand } \\
\text { matig fijn zand } \\
\text { relative fine sand } \\
\text { middelfijn zand } \\
\text { fine sand } \\
\text { zeer fijn zand } \\
\text { very fine sand } \\
\text { uiterst fijn zand } \\
\text { extremely fine sand } \\
\text { uiterst fijn zand } \\
\text { extremely fine sand }\end{array}$ & $\begin{array}{r}<50 \\
50-80 \\
80-120 \\
120-180 \\
180-270 \\
270-400\end{array}$ & \\
\hline
\end{tabular}




\section{I T E R A T U UR}

Alserda, Tн. Growth and root development of lowland rice and its relation to oxygen supply. Plant and Soil; 5 (1953): 1-28.

- De zuurstofvoorziening-van plantenwortels. In: De plantenwortel in de landbouw. 's-Gravenhage, 1955 . p. $98-106$.

Bakrer, D. en D. T. Biewinga. Het riet in de Noordoostpolder. Zwolle, 1957. (Van Zee -. tot Land; nr. 21).

BERKMANN, M. Untersuchungen über den Einflusz der Pflanzenwurzeln auf die Struktur des Bodens. Melle i.H., 1913. (Proefschr. München).

Bertrand, A. R. and H. KoHNKE. Subsoil conditions and their effects on oxygen supply and the growth of corn roots. Soil Sci. Soc. Am. Proc.; 21 (1957), nr. 2.

BoER, P. G. DE. De technische uitvoering van het ondergrondbreken in de Noordoostpolder. In: Versl. van-de ontwikkelingsdag voor de Landbouwk. opzichters van de Directie van de Wieringermeer; no. 16. Zwolle, 1953. p. 15-27.

Boonstra, A. E. H. R. Het begrip ,wortelwaarde". In: De plantenwortel in de landbout. 's-Gravenhage, 1955. p. 107-118.

Bryant, A. E. Comparison of anatomical and histological differences between roots of barley grown in aerated and non aerated culture solutions. Plant Physiology; I (1934): 389-391.

Buzss, O. Beitrag zur Methodik der Diagnostizierung verdichteter Bodenhorizonte und Ergebnisse von Untergrundlockerungsversuchen auf schweizerischen Ackerbödèn. Landw. Jahrb. Schweiz; $1950: 4-68$.

Cleveringa, C. J. De ontwikkeling van het wortelstelsel van cultuurgewassen en onkruiden in de Noordoostpolder. Kampen, 1943. (Intern rapport Directie van de Wiexingermeer).

- Het onderzoek van .plantenwortels in hun natuurlijk milieu met behulp van eenvoudige middelen. In: De plantenwortel in de landbouw. 's-Gravenhage, 1955. p. 192-198.

Domingo, W. R. De physische rijping van de jonge Zuiderzeeafzettingen in de Noordoostpolder. Zwolle, 1951. (Van Zee tot Land; $n r .2$ ).

Fenrenbacher, J. B. and J. D. Alexander. A method for studying corn root distribution using a soil core sampling machine and shaker type washer. Agron. Journ.; 47 (1955): 468-472.

Fox, R. L., J. E. WEAVER and R. C. LIPPS. Influence of certain soil-profile characteristics upon the distribution of roots of grasses. Agron. Journ.; 45 (1953): $583-589$.

Fox, R. L. and R. C. Lipps.. a. Influence of soil-profile characteristics upon the distribution of roots and nodules of alfalfa and sweetclover. Agron. Journ.; 47. $(1955): 361-367$.

- b. Subirrigation and plant nutrition. I. Alfalfa root distribution and soil properties. Soil. Sci. Soc. Am. Proc.; 19 (1955): 468-473.

GiLl, W. R. and R. D. Miller. A method for study of the influence of mechanical impedence and aeration on the growth of seedling roots. Soil Sci. Soc. Am. Proc.; 20 (1956): 154-157.

Gliemerotr, G. Bearbeitung und Düngung des Unterbodens in ihrer Wirkung auf Wurzelentwicklung, Stoffaufnahme und Pflanzenleistung. Zeitschr. Acker- u. Pflanzenbau; 96 (1953): 1-44. 
- Untersuchungen über Ausbildung und Leistung der Keim- und Kronenwurzeln bei Sommergetreide. Zeitschr. Acker-u. Pflanzenbau; 103 (1957):1-21.

GoedewaAgen, M. A. J. Het wortelstelsel der landbouwgewassen. 's-Gravenhage, 1942.

- a. Samenvattende beschouwing betreffende de inhoud van de in deze publicatie opgenomen mededelingen. In: Goedewaagen, M. J. A. e.a. Wortelgroei in gronden, bestaande uit een bovengrond van klei en een ondergrond van zand. s-Gravenhage, 1955. p. 7-18. (Versln. Landbouwk. Onderzoekingen; nr. 61.7).

- b. De oecologie van het wortelstelsel der planten. In: De plantenwortel in de landbouz. 's-Gravenhage, 1955. p. 31-68.

Görbinc, J. Kalkzustand und Wurzelentwicklung der Zuckerrübe. Zuckerrübenbau; 12 (1930): 125-136.

Hänsel, H. Entwicklungs Relationen verschiedener Organen von Winterweizen. Zeitschr. Pflanzenzüchtung; 35 (1955): 117-136.

HEYL, W. Der Einflusz der Bodenstrukturerkrankungen auf die Wurzelentwicklung landwirtschaftlicher Pflanzen. Kühn Archiv; 56 (1942): 215-246.

Hozksema, K. J. De natuurlijke homogenisatie van het bodemprofiel in Nederland. In: Boor en Spade VI. Wageningen, 1953. p. 24-30.

Hunter, A. S. and O. J. Kelley. The extension of plant roots in dry soil. Plant Physiology; 21 (1946): 445-45l.

Jongerius, A. Morfologische onderzoekingen over de bodemstructuur. 's-Gravenhage, 1957. (Proefschr. Wageningen).

Jonker, J. J. Enkele bewortelingsproblemen in de Noordoostpolder. In: Goedewaagen, M. A. J. e.a. Wortelgroei in gronden, bestaande uit een bovengrond van klei en een ondergrond van zand. 's-Gravenhage, 1955. p. 79-99. (Versin. Landbouwk. Onderzoekingen; $n$ r. 61.7).

Kaartbladen. Bodemkundige code- en profielenkaart van de Noordoostpolder. Zwolle, z. j. (Directie van de Wieringermeer (Noordoostpolderwerken)).

KaLisvaART, C. De waardebeoordeling van de mariene gronden in de Wieringermeer en de Noordoostpolder. Landbouwk. Tijdschr.; 61 (1949) : 309-320.

KмосH, H. G., e.a. Root development of winterwheat as influenced by soil moisture and nitrogen fertilization. Agron. Journ.; 49 (1957): 20-25.

KöhnLein, J. und H. VetTer. Exnteruckstände und Wurzelbild. Hamburg, enz., 1959.

Könekamp, A. H. Teilergebnisse von Wurzeluntersuchungen. Zeitschr. Pflanzenernährung, Düngung $u$. Bodenkunde; 60 (1953): 113-124.

Kraus, C. Zur Kenntnis der Verbreitung der Wurzeln im Beständen von Rein- und Mischsaaten. Fühlings Landw. Ztg.; 63 (1914): 337-362, 369-383, 401-412.

LARGE, E. C. Growth stages in cereals, illustration of the Feekesscale. Plant Pathology; $3(1954): 128-129$.

Lieshout, J. W. van. Wortelconcurrentie. In: De plantenwortel in de landbouw. 's:Gravenhage, 1955. p. 126-138.

- De beworteling van een aantal Jandbouwgewassen. 's-Gravenhage, 1956. (Versin. Landbouwk. Onderzoekingen; $n r .62,16)$.

Loenwrng, W. F. Physiological aspects of the effect of continuous soil aeration on plant growth. Plant Physiology; 9 (1934): 567-583.

Merbitz, H. und W. Nitscr. Erfahrungen mit Untergrundbearbeitung im feuchten Jahre 1936. Dsche Landw. Presse; 1937, nr. 26 und 27.

Opirz, K. Untersuchungen über Bewurzelung und Bestockung einiger Getreidearten. Breslau, 1904. (Proefschr. Breslau).

Pavlychenko, T. K. a. Quantitative studies on the entire root systems of weed and crop plants under field conditions. Ecology; 18 (1937).

- b. The soil block washing method in quantitative root study. Canad. Journ. Res.; C 15 (1937): 33-57.

Peterson, J. B. Relation of soil air to roots. Soil Sci.; 70 (1950): 175-185.

Prummel, J. Rijenbemesting. Landbouwk. Tijdschr.; 62 (1950): 620-627.

PIJLS, F. W: G. Het bodemprofiel in verband met de productiviteit van de grond. Landbouwk. Tijdschr.; 61 (1949): 298-308.

Quisper, A. Het oxydatie-reductieniveau van de grond. Zwolle, 1946. (Intern rapport Directie van de Wieringermeer). 
Rrttenhouse, G. A visual method of estimating two dimensial sphericity. Journ. Sedimentary Petrology; 13 (19 ): $79-81$.

RoopenburG, J. W. M. Zuurstofgebrek in den grond in verband met wortelrot. Utrecht, 1927. (Proefschr. Utrecht).

SchneIDeR, G. Vegetationsversuche mit 88 Hafersorten. Landw. Jahrb.; 42 (1912): $767-833$ :

Schreven, D. A. vaN. Microbiologische rijping van Zuiderzeegronden. Zwolle, 1957. (Intern rapport Directie van de Wieringermeer).

Schultze, R. Einflusz von Untergrundbearbeitung auf Struktur, Wassergehalt, Reaktionsverhältnisse und Ertrag. Giessen, 1940. (Proefschr. Giessen).

SchuURman, J. J. en G. F. Makkink. Bewortelingsonderzoek op een beregeningsproefveld te IJsselstein (Utrecht). Landbouwk. Tijdschr.; 67 (1955) : 283-295.

Sieben, W. H. De ontwatering van de zavelgronden in de Noordoostpolder. Zwolle, 1951. (Van Zee tot Land; nr. 2).

Simon, W. und D. Eich. Probleme und Methoden der Wurzeluntersuchungen. Zeitschr. Acker- u. Pflanzenbau; 100 (1955): 179-198.

Veldman, G. Over de landbouwkundige waarde van lichte mariene gronden. Zwolle, 1948. (Intern rapport Directie van de Wieringermeer).

Vervelde, G. J. De zoutopname door de wortel. In: De plantenwortel in de landboutw. 's-Gravenhage, 1955. p. 90-97.

Verhmeyer, F. J. and A. H. Hendrickson. Soil density as a factor determining the permanent wilting percentage. Soil Sci.; 62 (1946): 451-456.

- Soil density and root penetration. Soil Sci.; 65 (1948): 487-493.

VISSER, W. C. De samenstelling van productiviteitsschattingen op grond van vruchtbaarheidskenmerken. Landbouwk, Tijdschr.; 61 (1949) : 321-334.

Weaver, J. E. Root development of field crops. New York, 1926.

Wells, C. B. The practice of sub-soiling. A brief reyiew. Joutrn. Austr. Inst. Agric. Sci.; 22 (I956): $247-251$.

Wessetrng, J. Enige aspecten van de waterbeheersing in landbouwgronden. 's-Gravenhage, 1957. (Proefschr. Wageningen).

Wiersum, L. K. a. Problemen en methodiek van fysiologisch-oecologisch wortelonderzoek. T. N.O. nieuws; 12 (1957):8-11.

- b. The relationships of the size and structural rigidity of pores to their penetration by roots. Plant and Soil; 9 (1957): 75-85.

Wigcers, A. J. De wording van het Noordoostpoldergebied. Zwolle, 1955. (Proefschr. Amsterdam).

Williams, T. E. and H. K. BAKER. Studies on the root development of herbage plants. Journ. Brit. Grassl. Soc.; 12 (1957) : 49-55.

WIr, C. T. DE. A physical theory on placement of fertilizers. Z. pl., 1953. (Proefschr. Wageningen).

WoodrufF, C. M. and D. D. SMrrt. Subsoil shattering and subsoil liming for crop production on clay-pan soils. Soil Sci. Soc. Am. Proc.; 11 (1947) : 539-572.

ZuUr, A. J. Over de veranderingen in den bodemkundigen toestand sinds den aanleg opgetreden op het zwaardere perceel van het proefveld te Kraggenburg. Zwolle, 1946. (Intern rapport Directie Wieringermeer).

Żjustra, K. De hoofdwortel van eenige graansoorten. 's-Gravenhage, 1922. (Versin. Landbouwk. Onderzoekingen; XXVI).

- Onderzoekingen over de eerste ontwikkelingsperiode der jonge graanplant. 's-Gravenhage, 1939. (Versin. Landbouwk. Onderzoekingen; 47 (i7) A). 


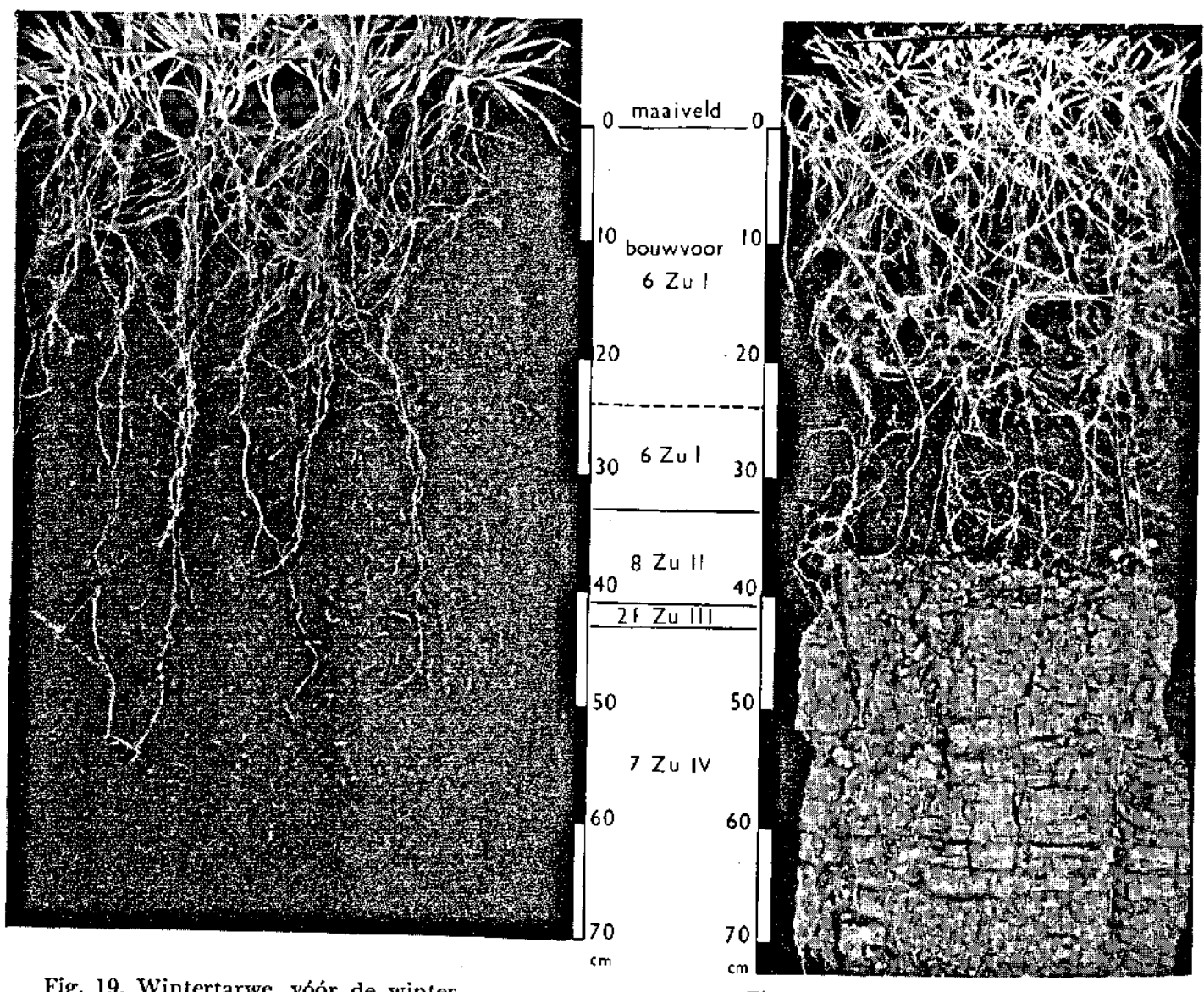

Fig. 19. Wintertarwe, vóór de winter.

Fig. 20. Wintertarwe in het voorjaar.

Winter wheat, before winter. Winter wheat, in spring. 


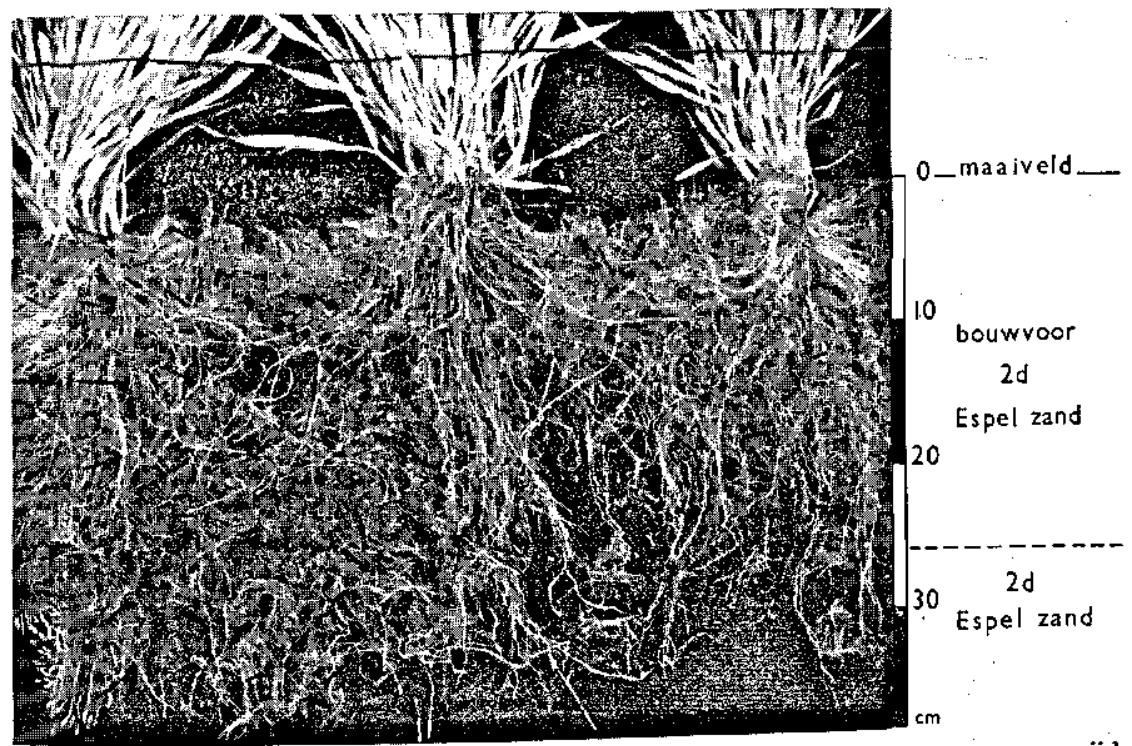

Fig. 21. Zomergerst, tijdens het uitstoelen. spring barley, tillering.

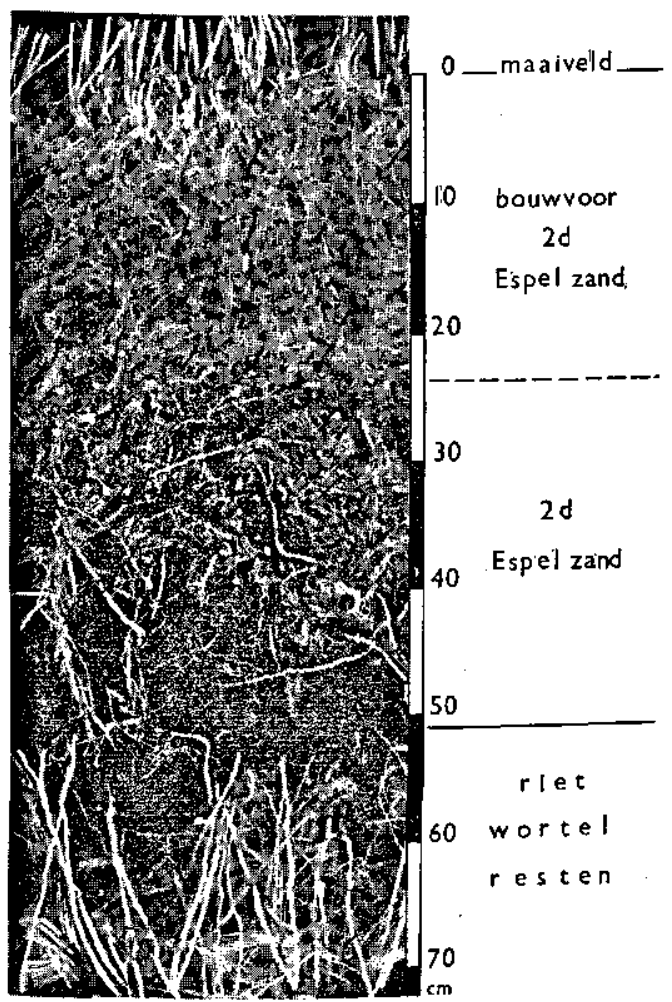

Fig. 22. Zomergerst, rijp.

Spring barley, mature. 

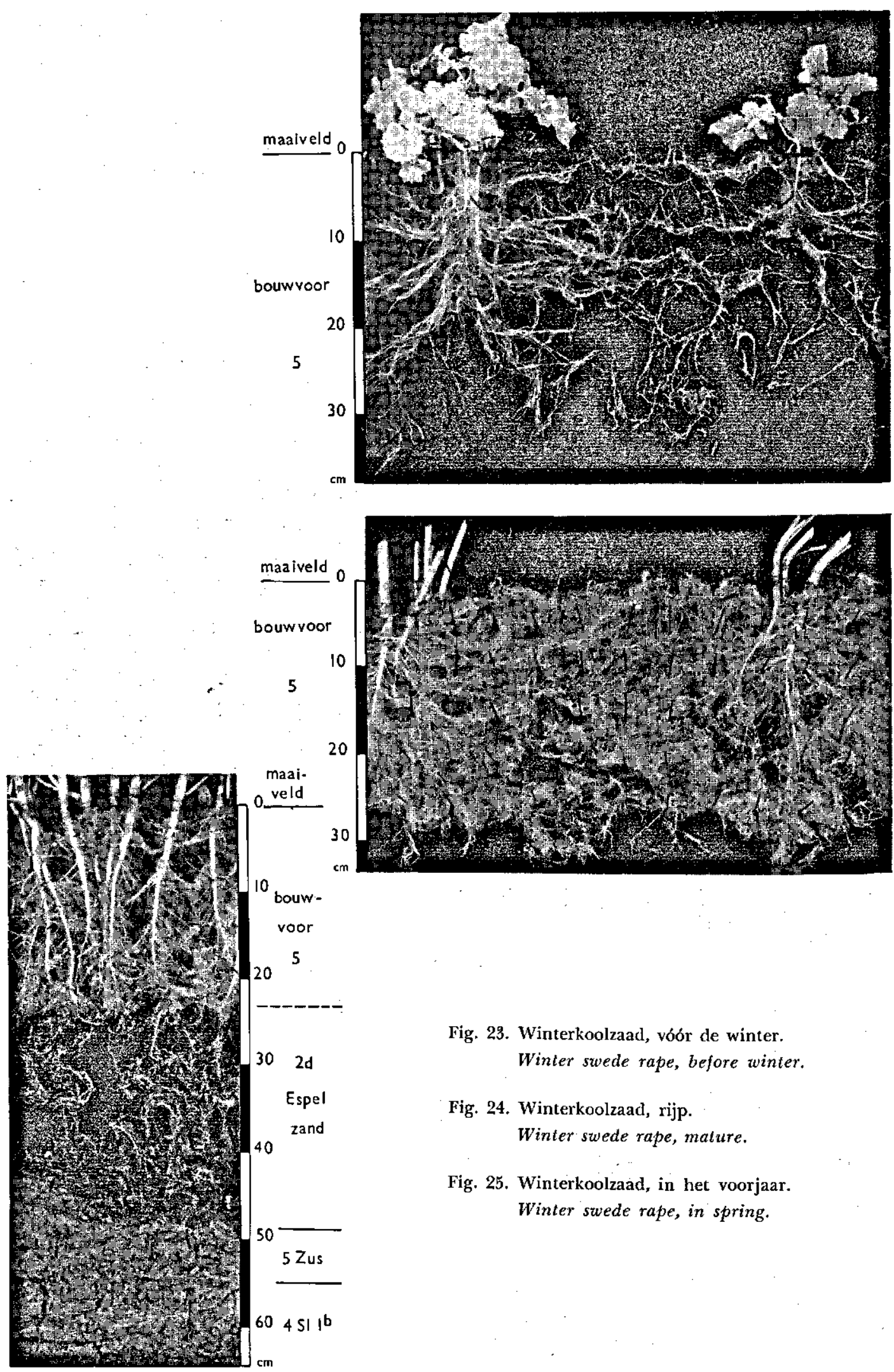

Fig. 23. Winterkoolzaad, vóór de winter. Winter swede rape, before winter.

Fig. 24. Winterkoolzaad, rijp. Winter swede rape, mature.

Fig. 25. Winterkoolzaad, in het voorjaar. Winter swede rape, in spring. 


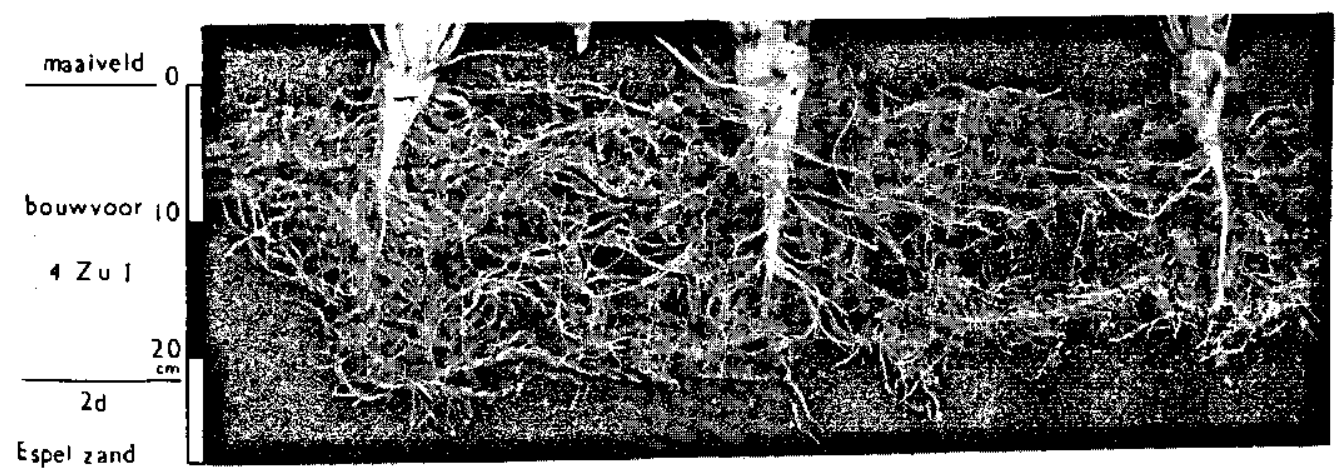

Fig. 26. Suikerbieten, in de zomer.

Sugar beet, during summer.

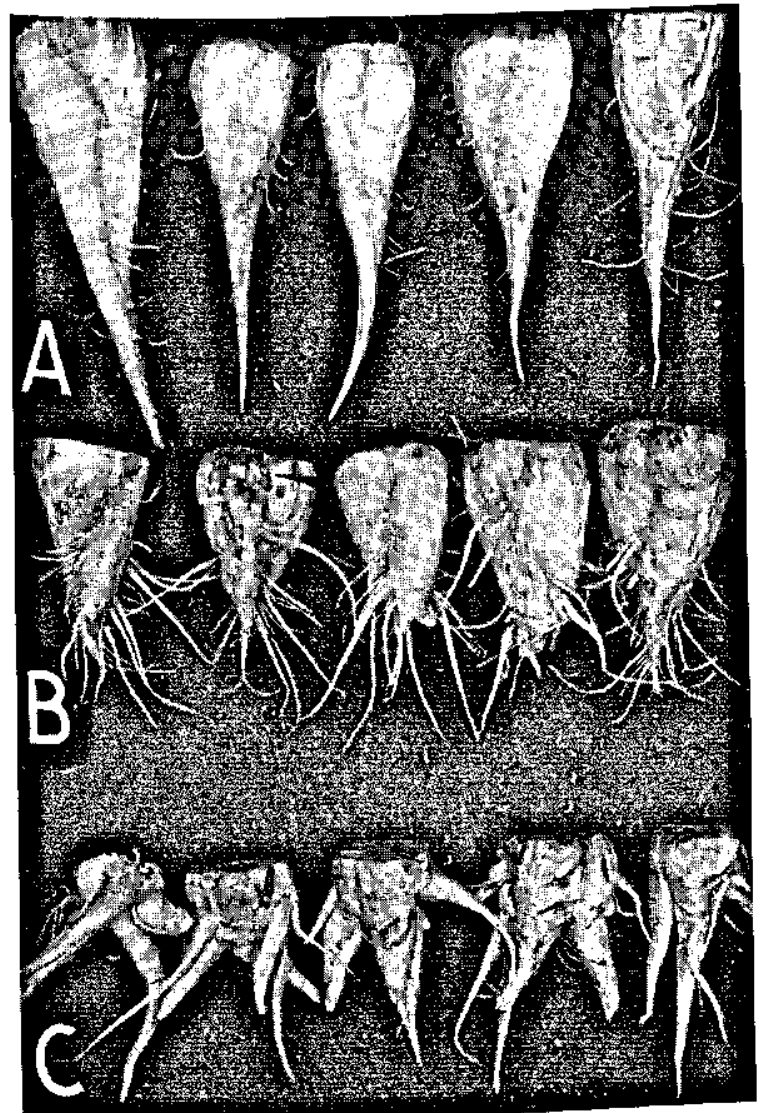

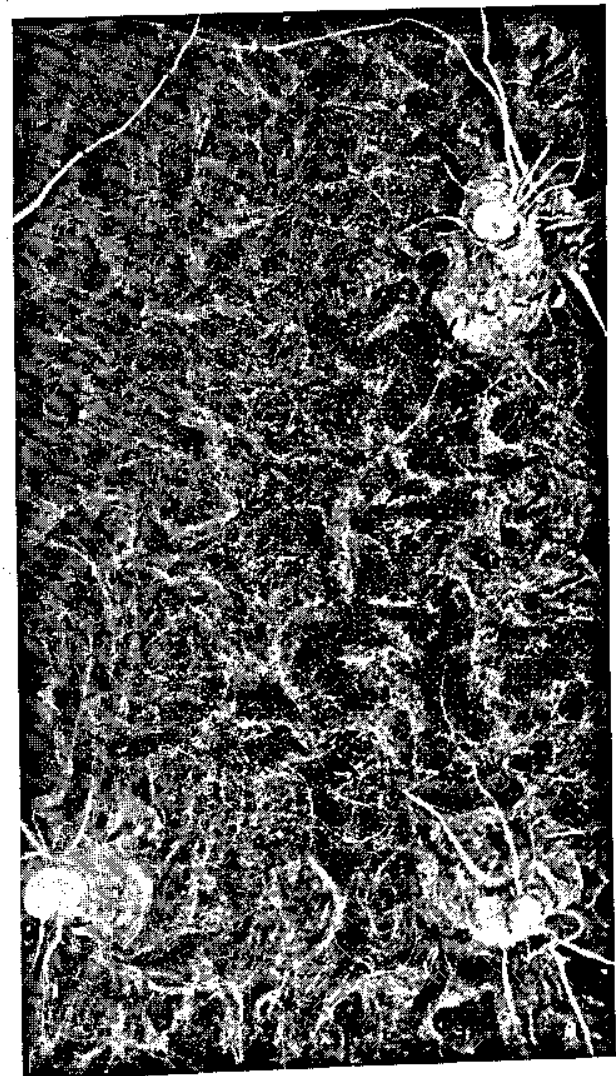

Fig. 27. Suikerbieten, in de herfst. sigar beet, worm's eye view.

Fig. 28. Suikerbietenvormen: Sugar beet shapes:
a. normaal; normal;
b. kort; short;
c. vertakt. branched. 


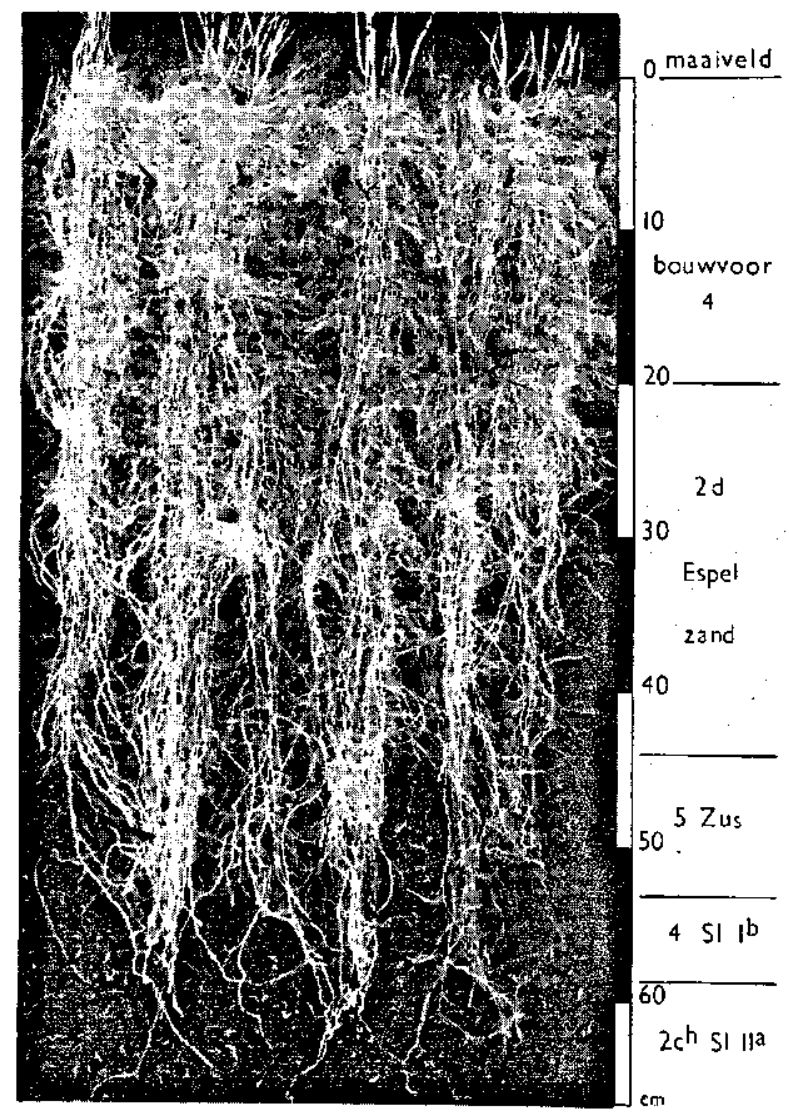

Fig. 29. Vlaś.

Flax.

Fig. 30. Groene erwt.

Green pea.

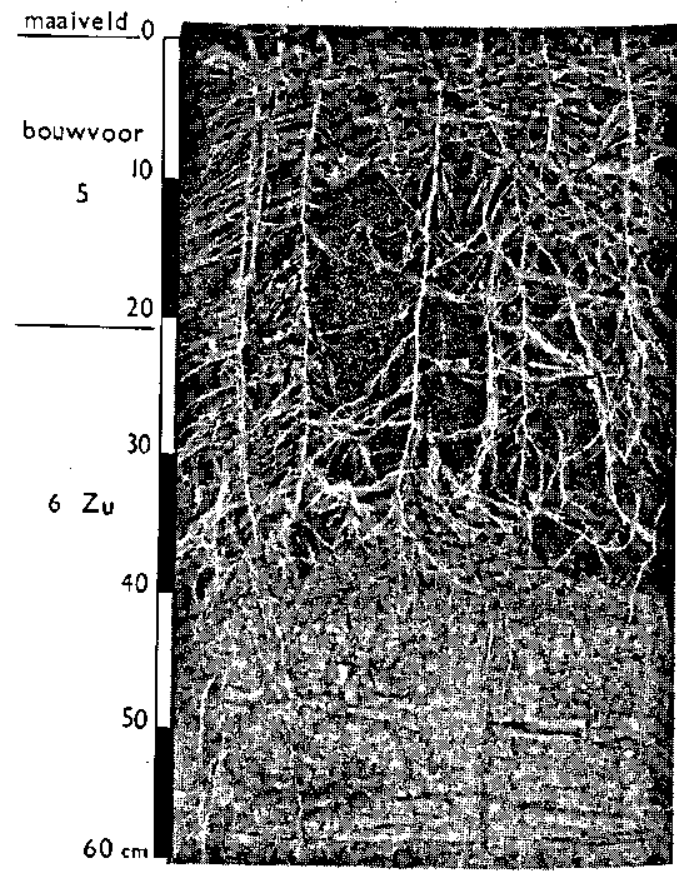


Fig. 31. Luzerne.
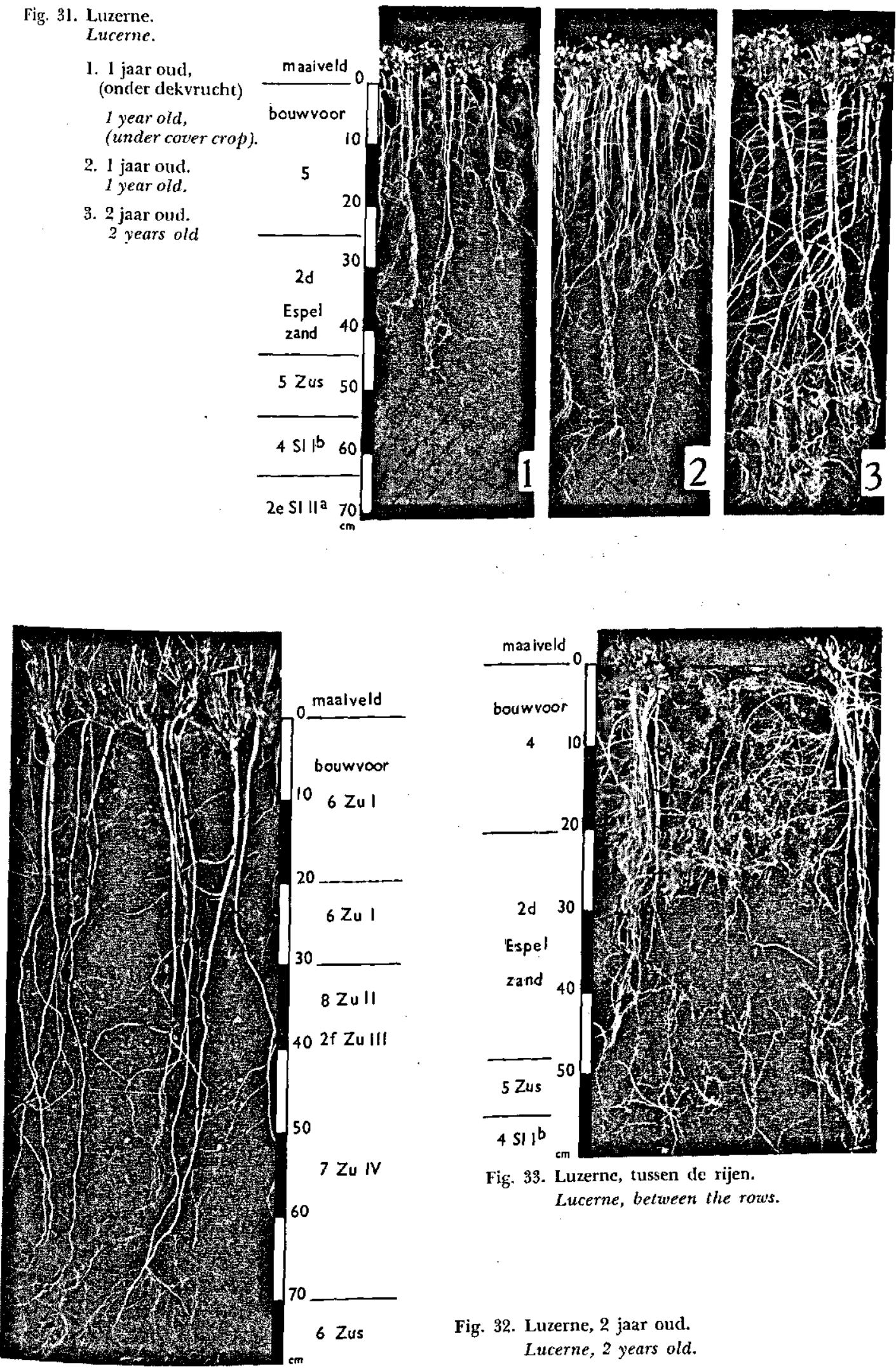

Fig. 33. Luzerne, tussen de rijen. Lucerne, between the rows.

Fig. 32. Luzerne, 2 jaar oud. Lucerne, 2 years old. 

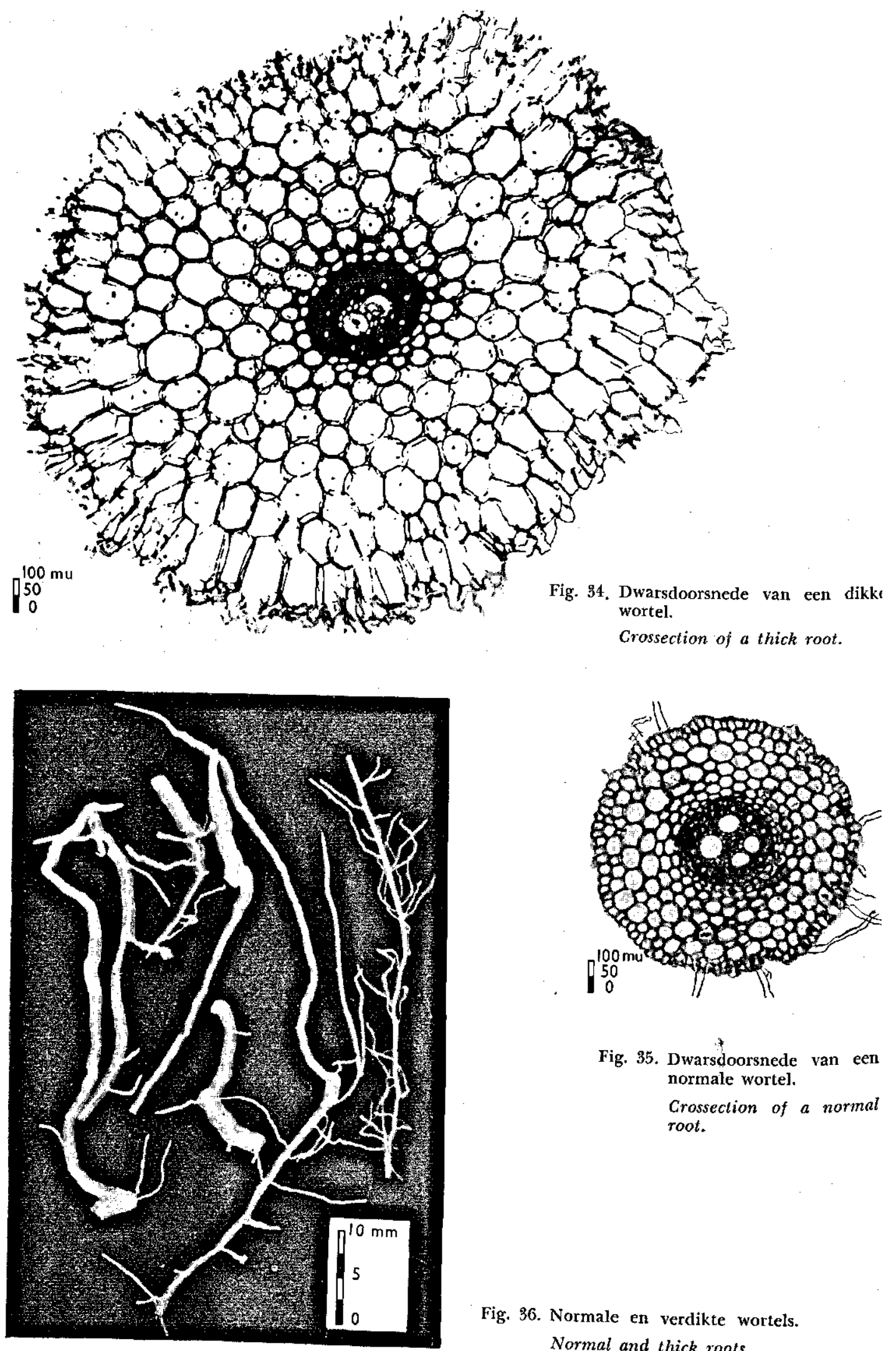

Fig. 35. Dwarsdoorsnede van een normale wortel.

Crossection of a normal root.

Fig. 36. Normale en verdikte wortels. Normal and thick roots. 


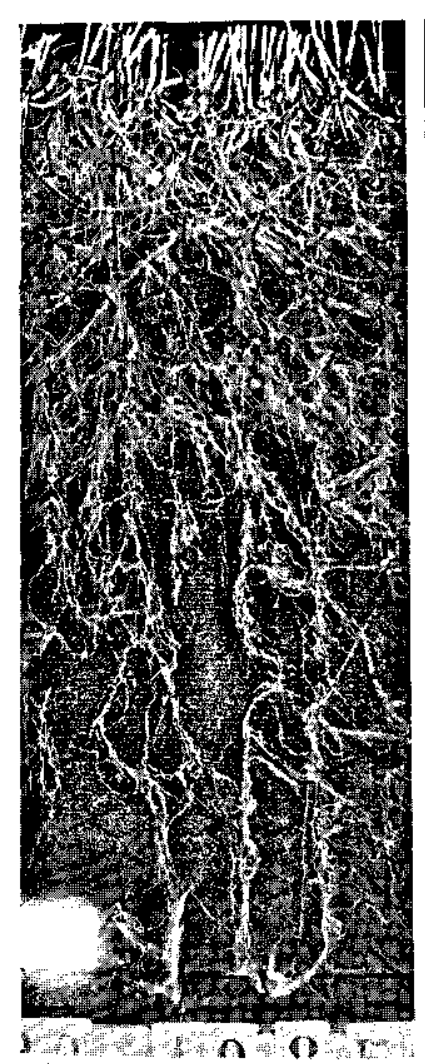

Fig. 37. Wintertarwe op kavel D 30.

Winter wheat on parcel $D 30$.

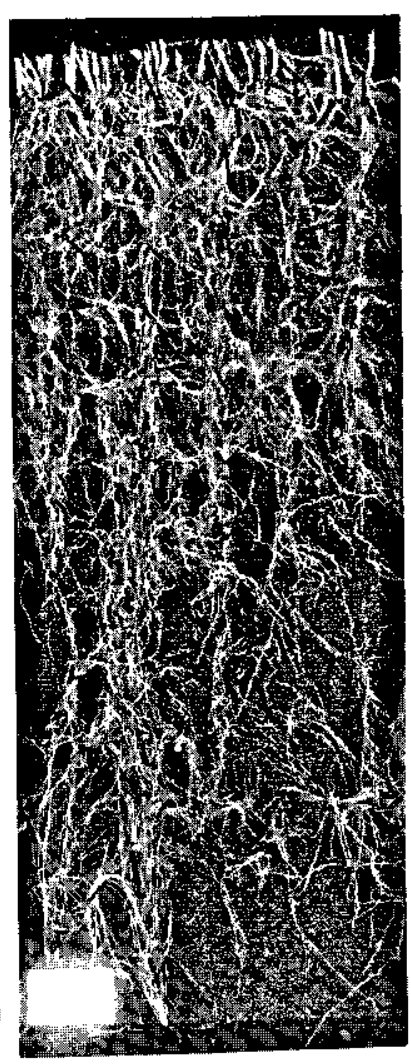

Fig. 38. Zomertarwe op kavel D 30.

Spring wheat on parcel $D 30$.

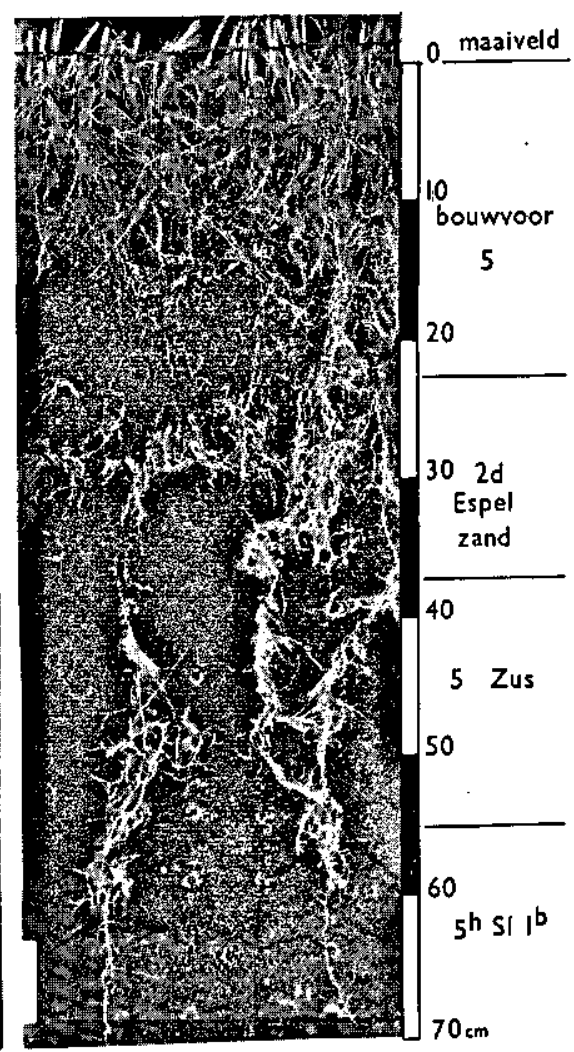

Fig. 39. Haver op kavel D 30. Oats on parcel $D 30$. 

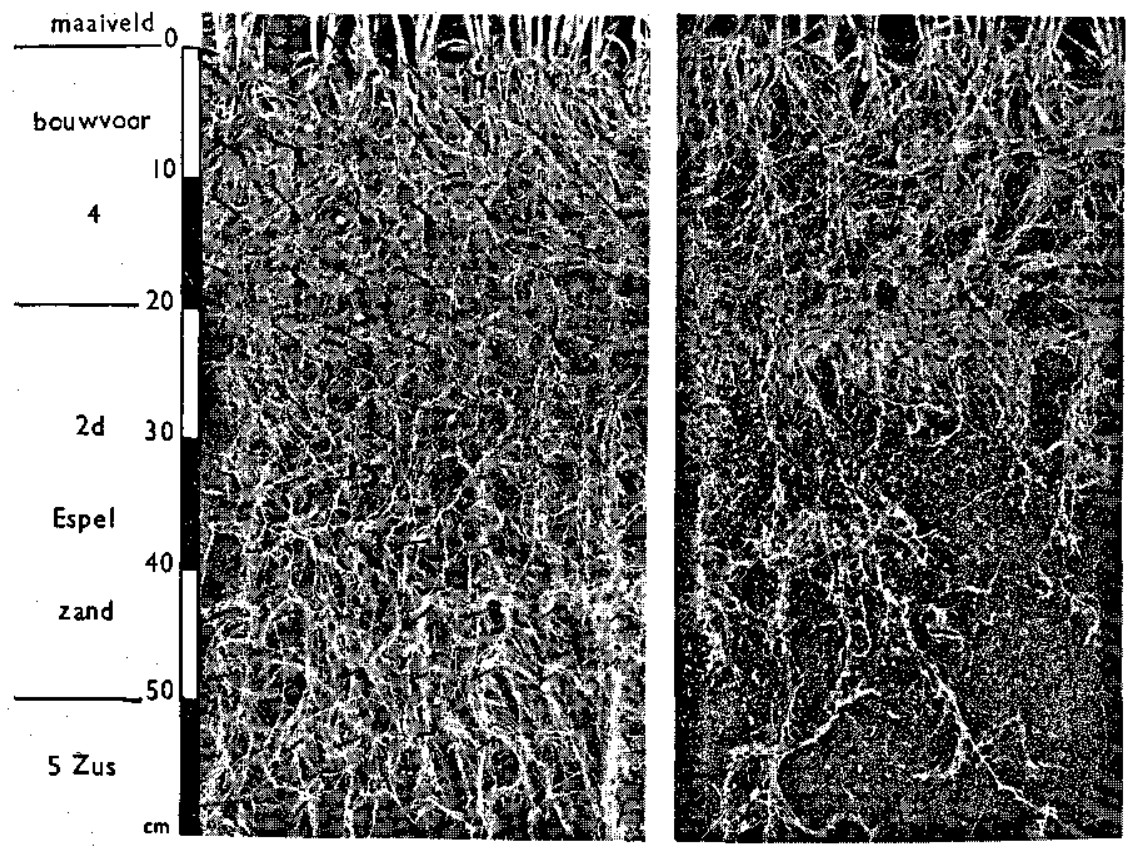

Fig. 40. Lang haverras op kavel D 24.

$A$ long oat variety on parcel $D 24$.

Fig. 41. Kort haverras op kavel D 24.

$A$ short oat variety on parcel $D 24$.

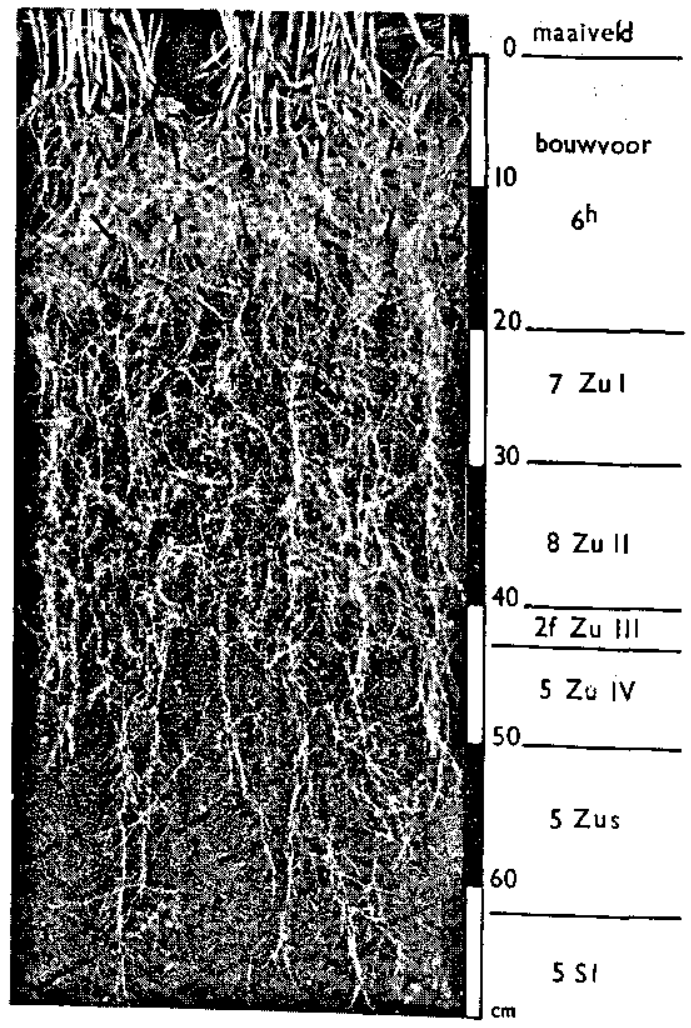

Fig. 42. Wintertarwe op kavel S 8 .

IVinter wheat on parcel $S 8$.

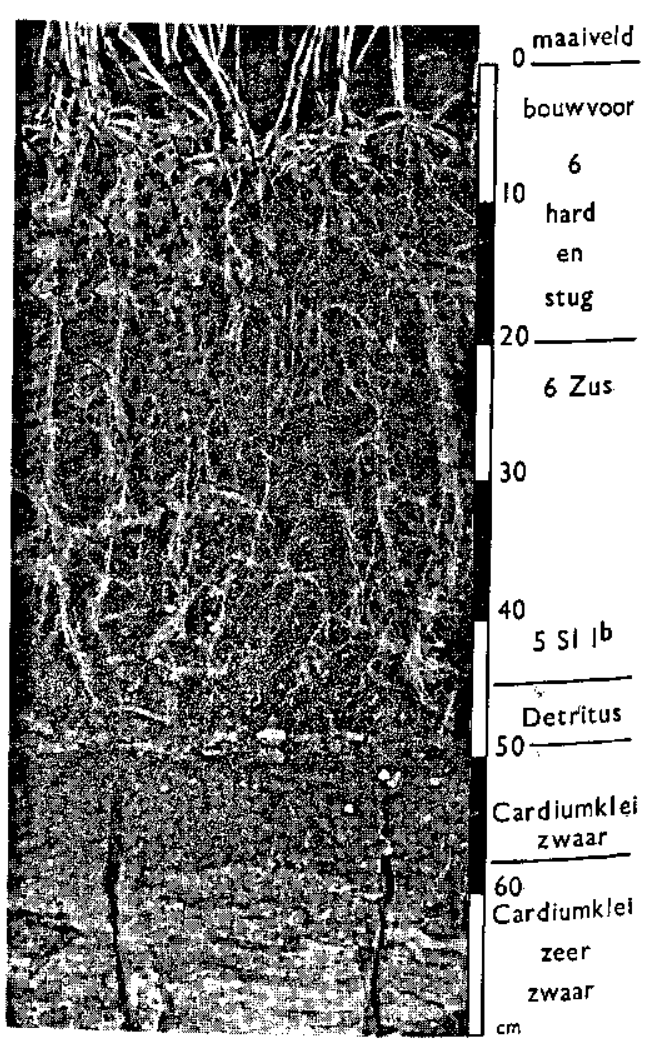

Fig. 43. Wintertarwe op kavel $\mathrm{H} 96$, klei in de ondergrond.

Winter wheat on parcel $H 96$, clay in the subsoil. 


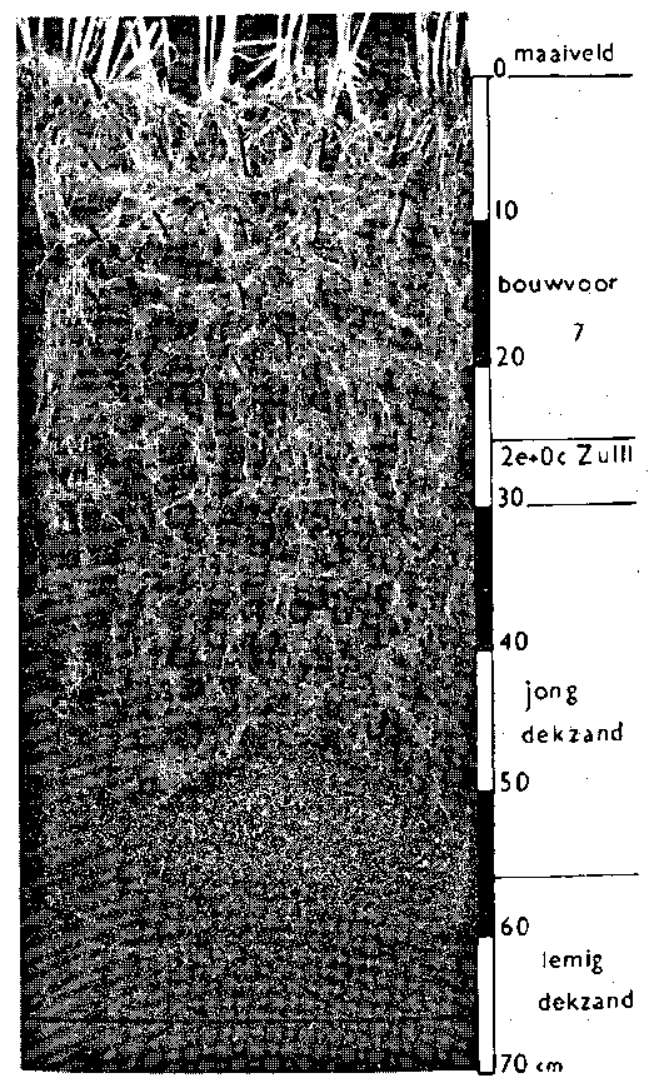

Fig. 44. Wintertarwe op kavel M 14, zand op $50 \mathrm{~cm}$ diepte.

Winter wheat on parcel $M 14$, sand at $50 \mathrm{~cm}$ below level.

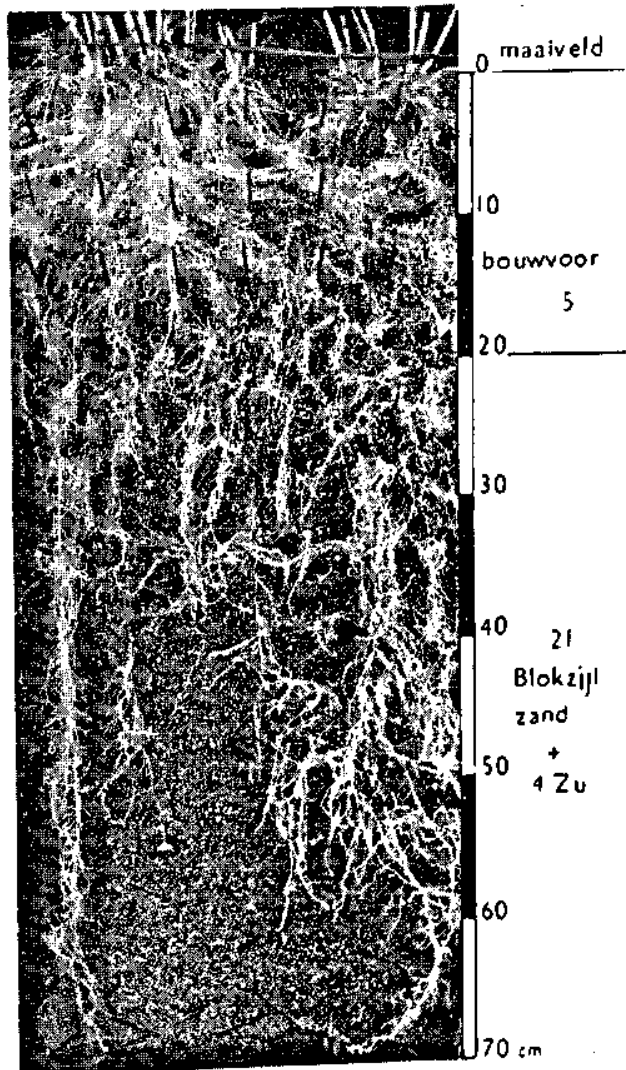

Fig. 45. Wintertarwe op kavel S 63, gediepploegd.

Winter wheat on parcel $\$ 63$, clay on sand profile, after deep ploughing. 


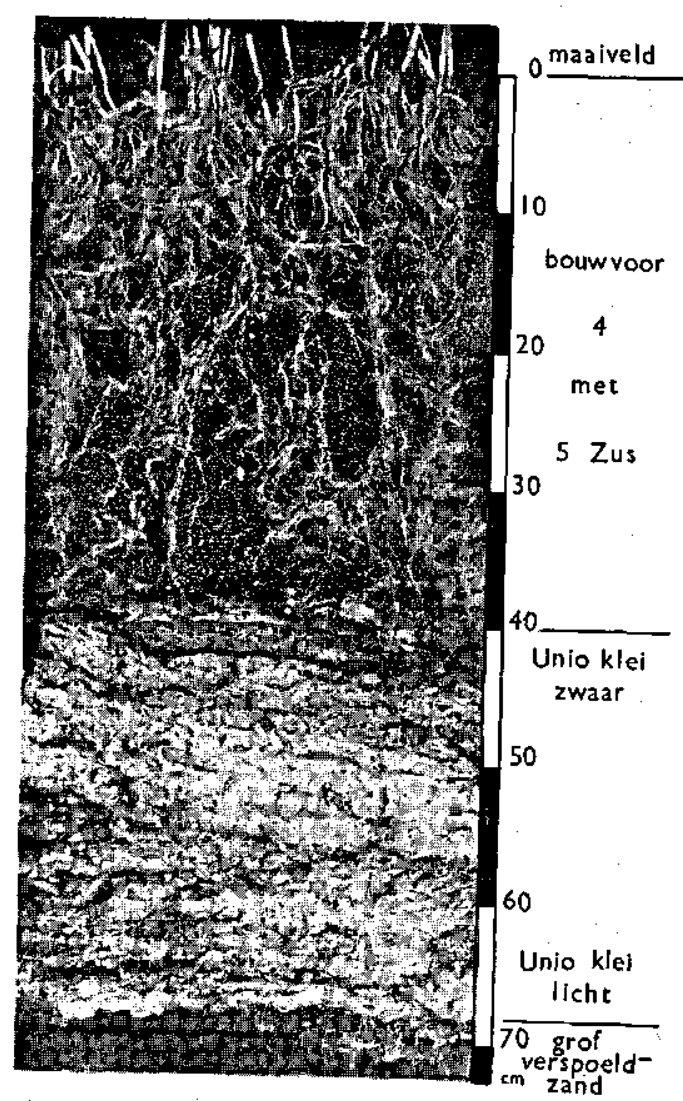

Fig. 46. Wintertarwe op kavel H I6, kwelderklei in de ondergrond. Winter wheat on parcel $\mathrm{H} 16$.

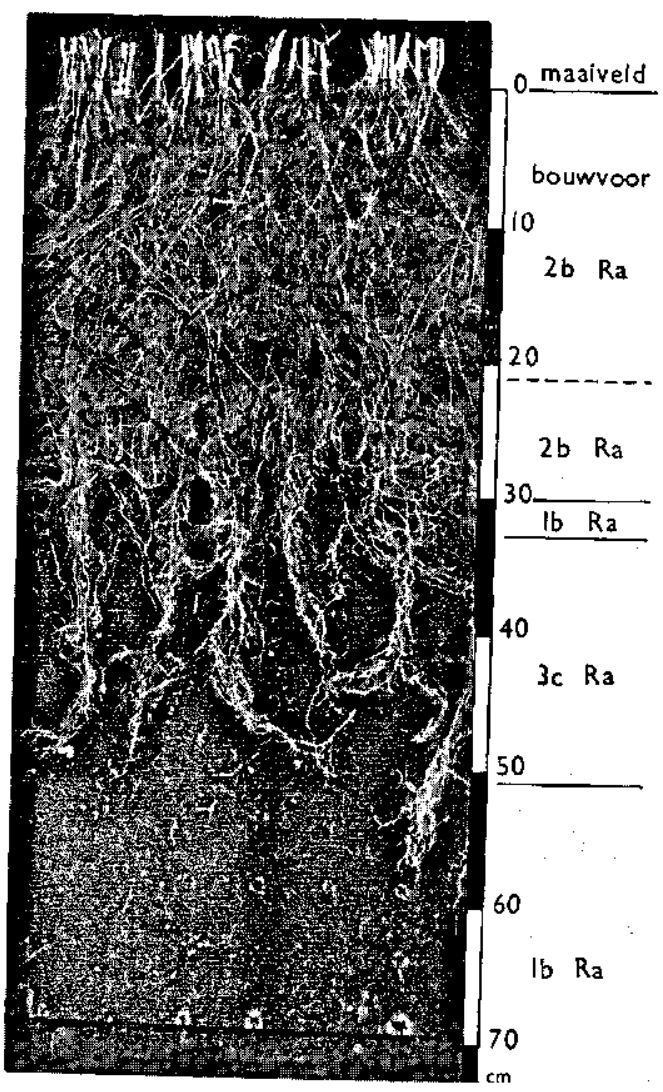

Fig. 47. Haver op kavel P 64, Ramspolzand, geïnfiltreerd.

Oats on parcel $P$ 64, coarse sand, subterraneous irrigation. 


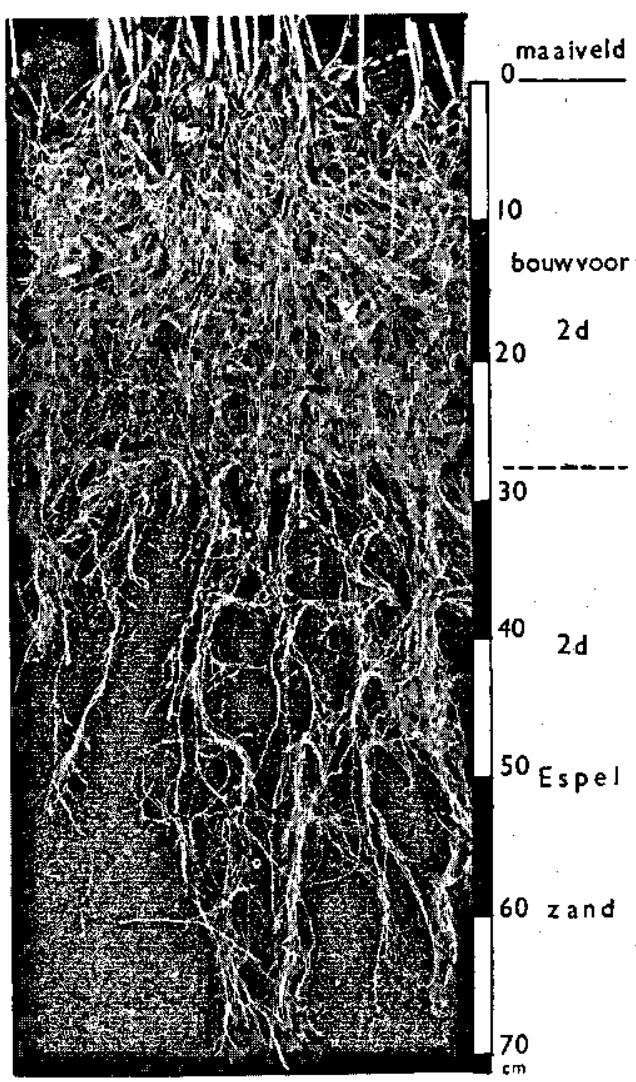

Fig. 48. Haver op kavel A 14, Espelzand, geondergrond tot $70 \mathrm{~cm}$ diepte. Oats on parcel $A$ 14, fine sand, subsoil tillage at $70 \mathrm{~cm}$ depth.

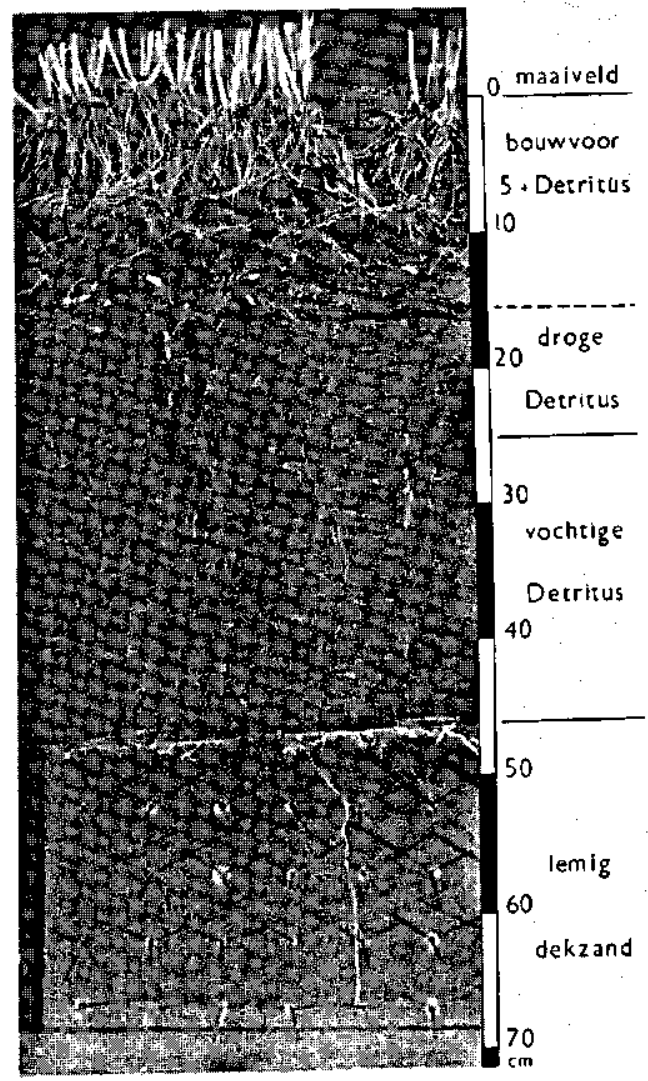

Fig. 49. Wintertarwe op kavel A 76, detritus-gyttja onder de bouwvoor. Winter wheat on parcel $A 76$, detritus-gyttja beneath the topsoil. 


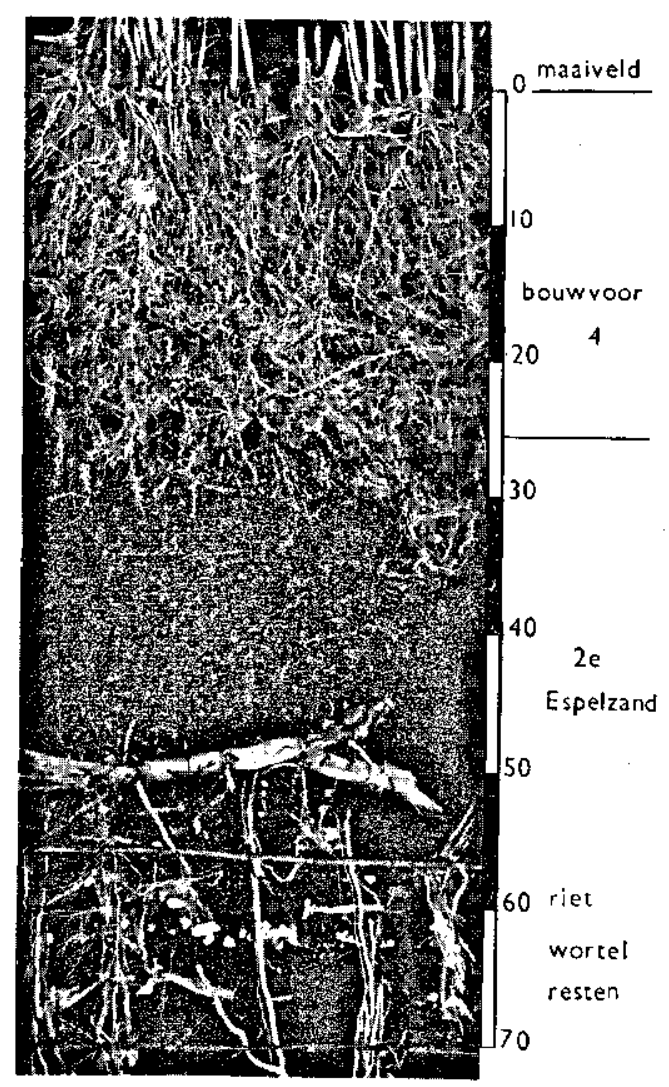

Fig. 50. Haver op kavel A 8, hoge grondwaterstand Oats on parcel $A$, high groundwatertable.

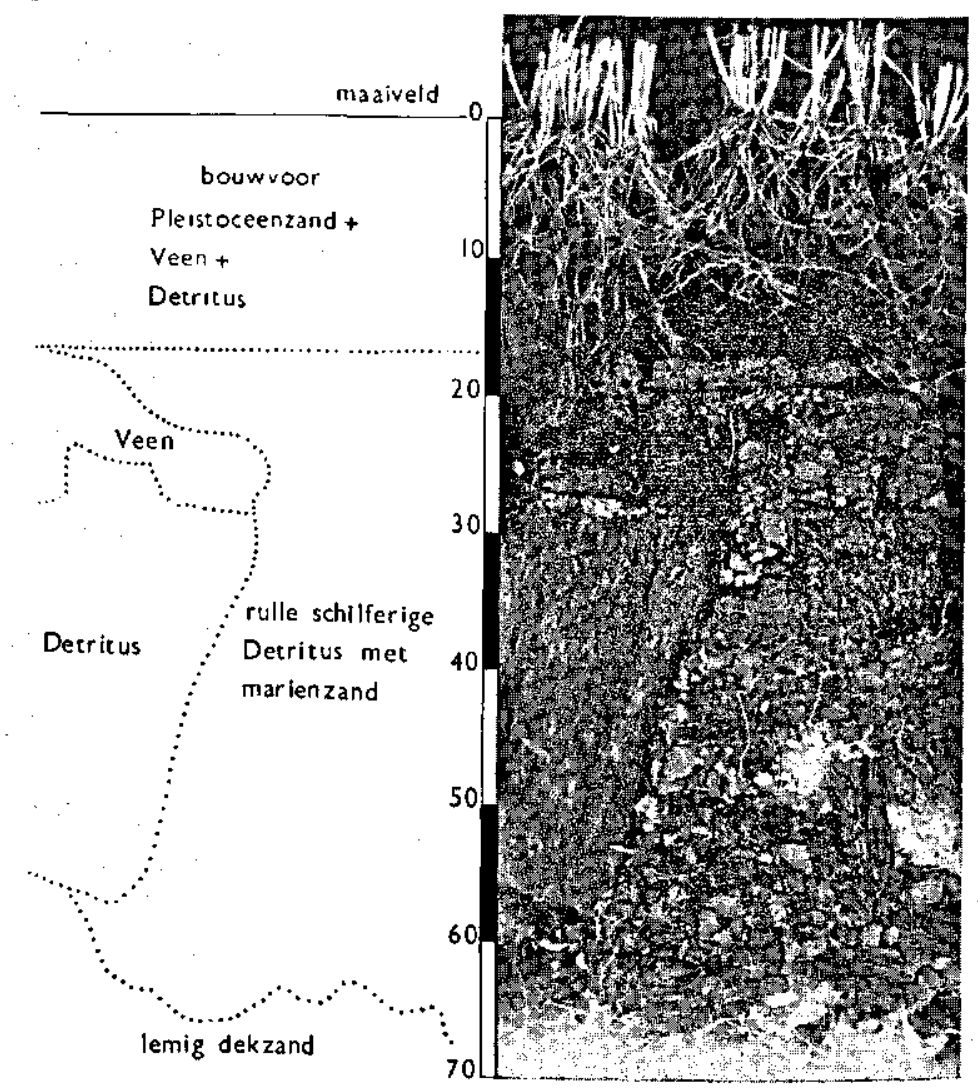

Fig. 51. Wintertarwe op kavel $\mathrm{K} 40$, gediepploegd veen op zandprofiel.

Winter wheat on parcel $K$ 40, peat. sand profile after deep ploughing. 


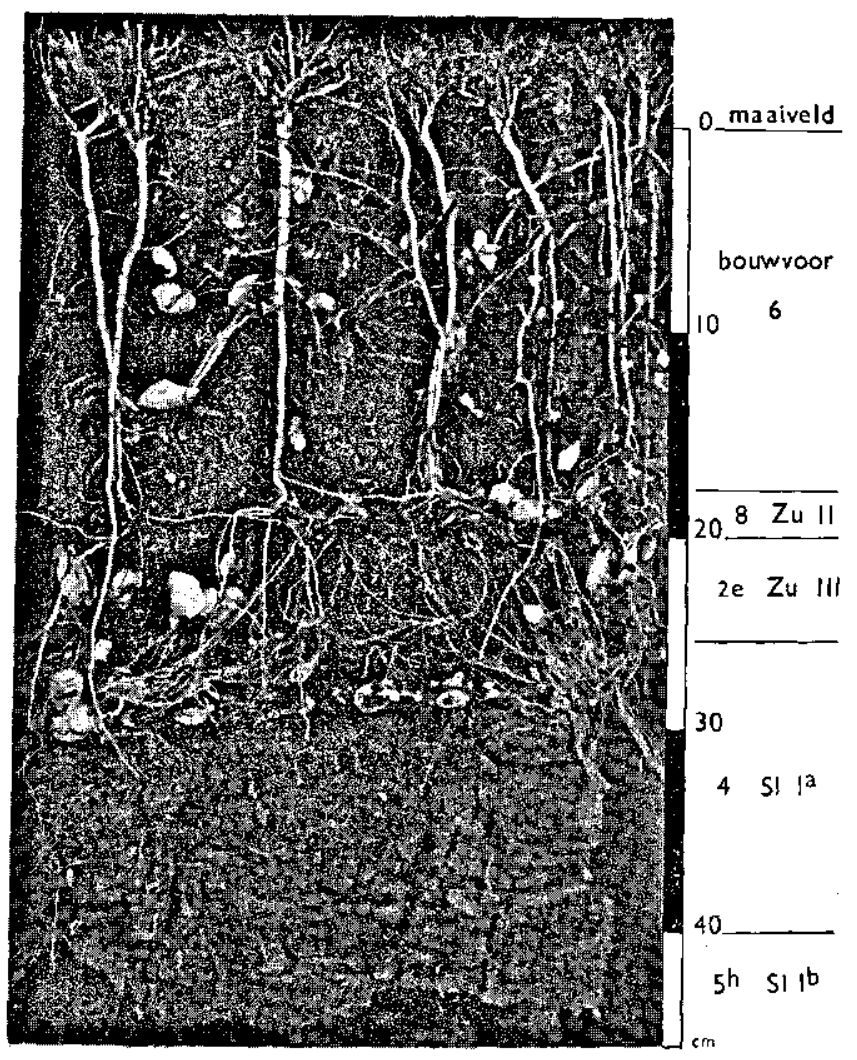

Fig. 52, Luzerne, kavel o 98, zonder ondergrondbewerking.

Lucerne, parcel $O$ 98, without subsoil tillage.

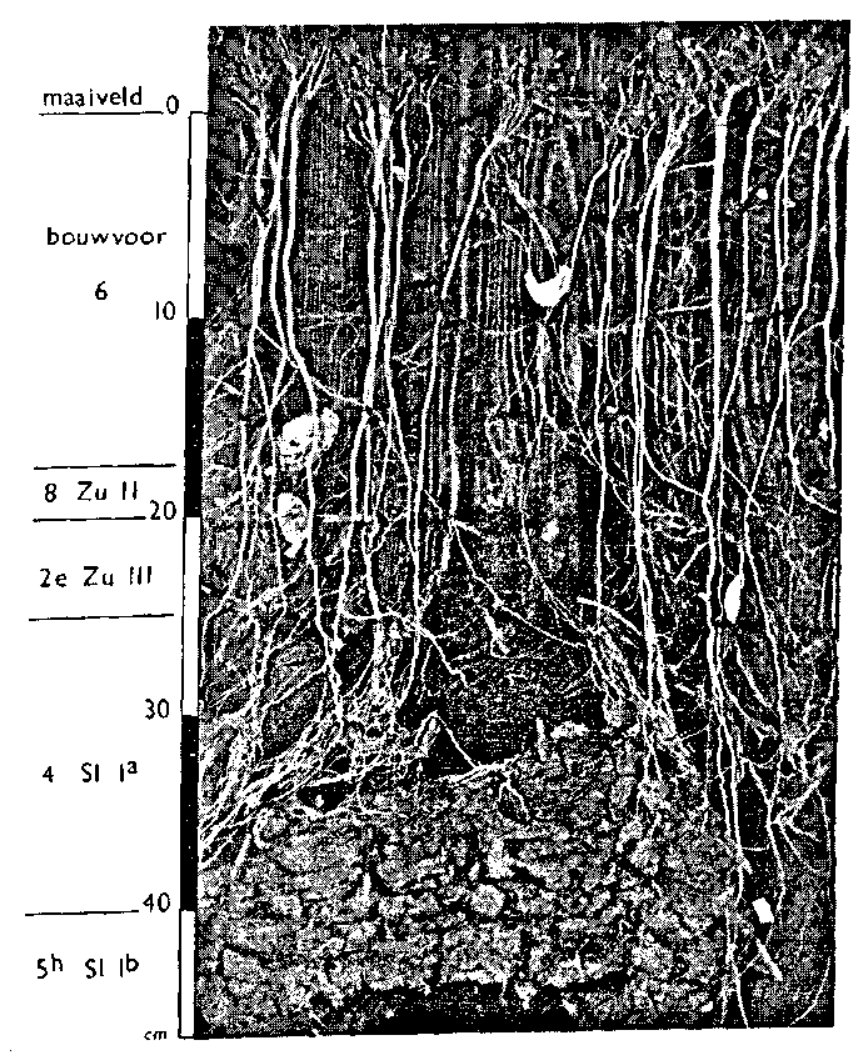

Fig. 53. Luzerne, kavel o 98, met ondergrondbewerking.

Lucerne, parcel $O 98$, with subsoil tillage. 


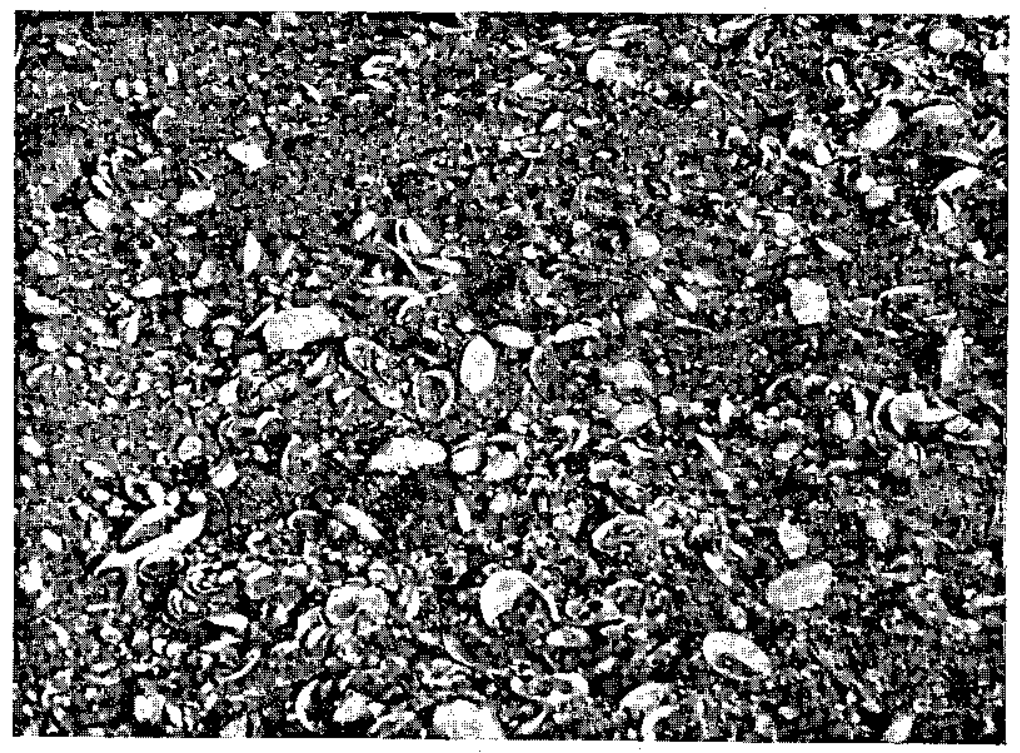

Fig. 54. Verslempte bouwvoor (D 24).

Collapsed topsoil in spring ( $D$ 24).

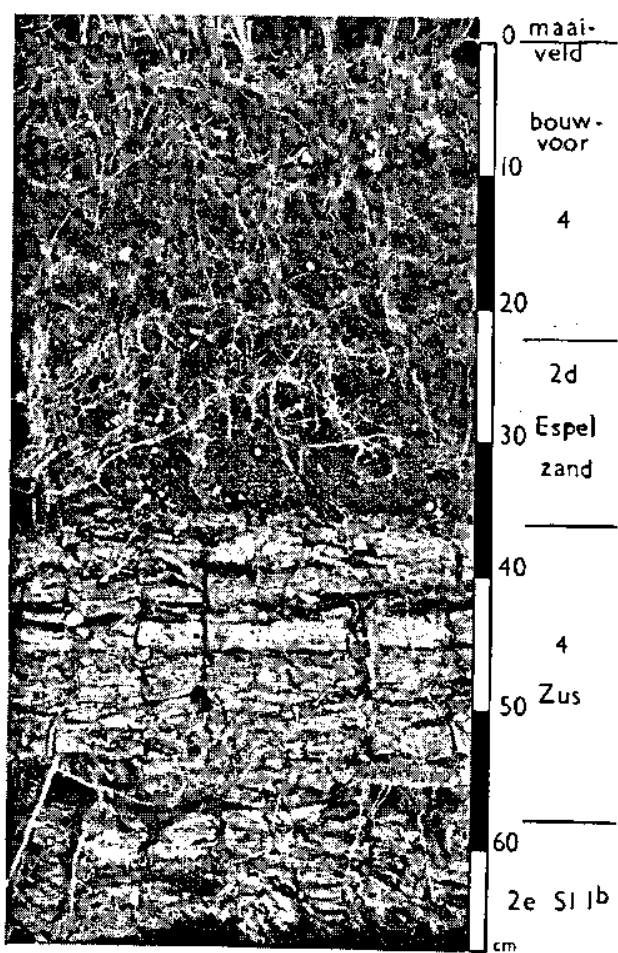

Fig. 55. Wortelontwikkeling (B 68). Root development (B 68).

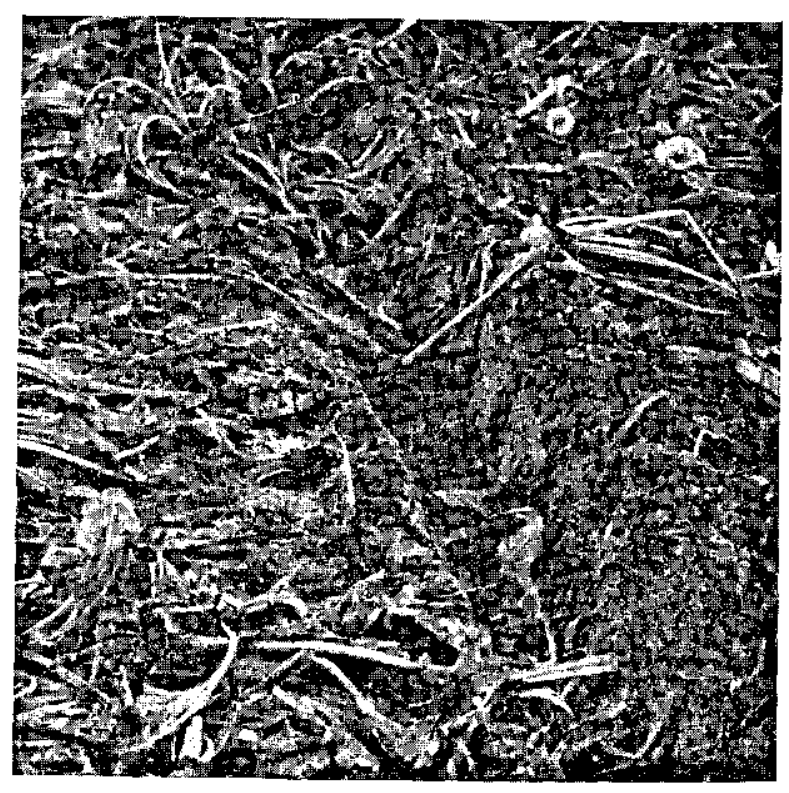

Fig. 56. Diepe wielsporen in de herfst (D 24). Deep wheel tracks in autumn (D 44).

Gedeelte van kavel D 24/B 68 zonder ondergrondbewerking.

Part of parcel D 24/B 68, not subsoiled. 
Fig. 57 Niet verslempte bouwvoor na de winter (D 24). Not callapsed topsoil in spring (D 24).

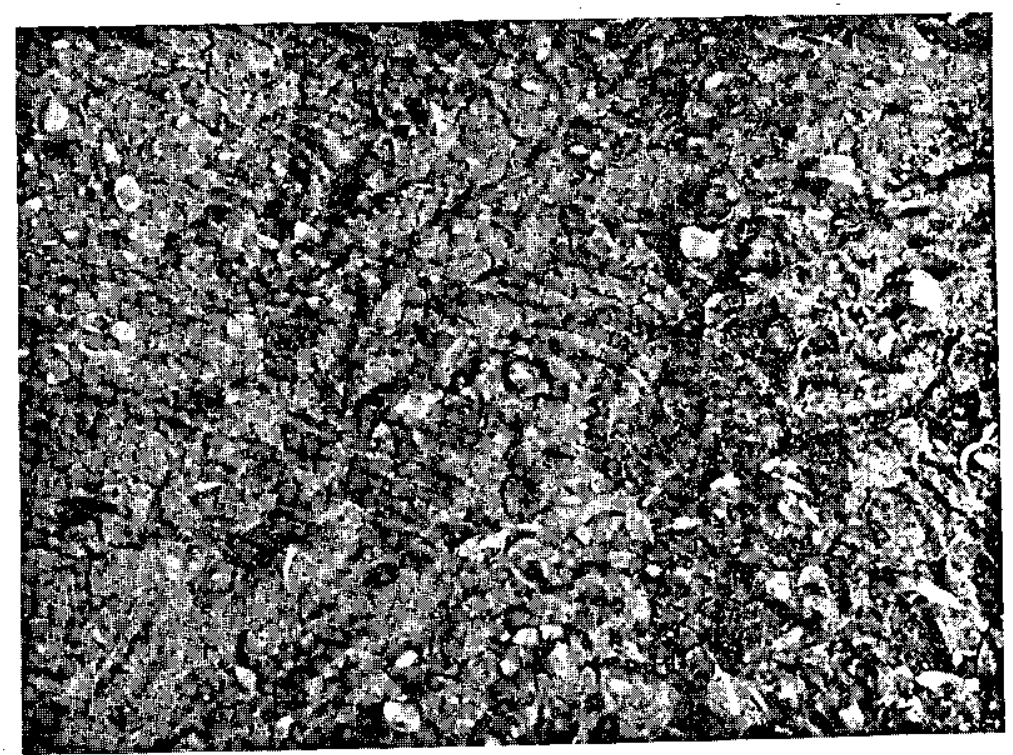

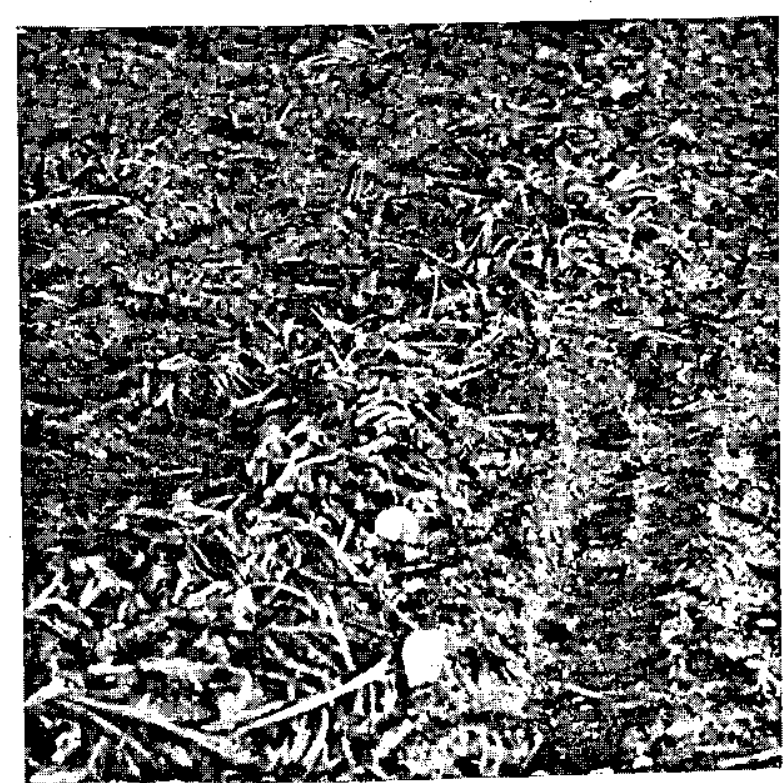

Fig. 58. Ondiepe wielsporen in de herfst (D 24). Shallow wheel tracks in autumn (D 24).

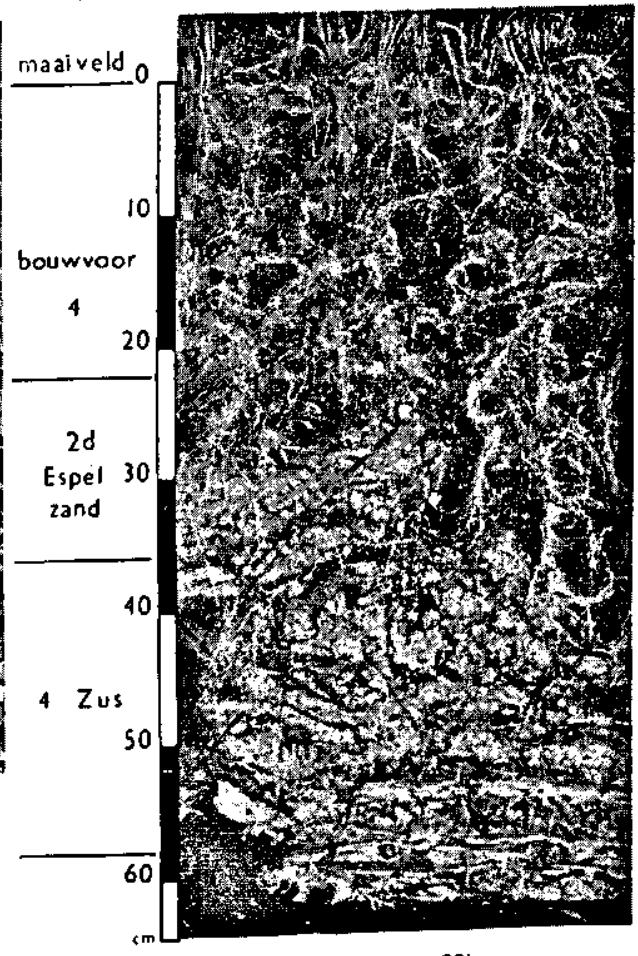

Fig. 59. Wortelontwikkeling (B 68). Rootdevelopment (B 68).

Geondergrond gedeelte van kavel
Subsoiled part of parcel $D 24 / B 68$. 


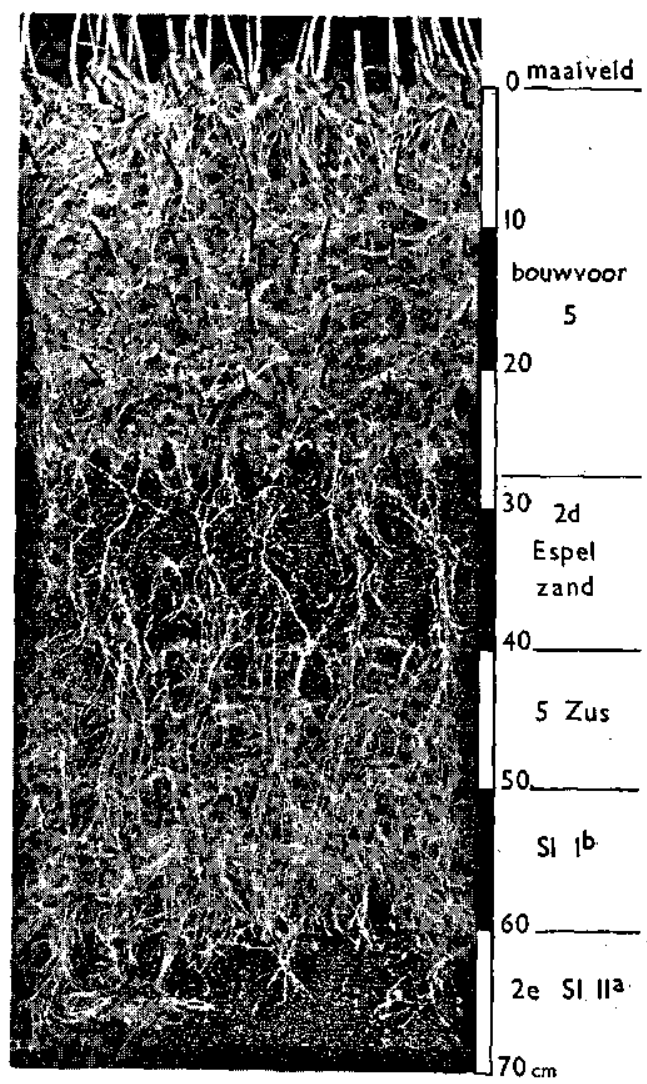

Fig. 60. Wintertarwe op kavel D 21, geondergrond tot $50 \mathrm{~cm}$ diepte.

Winter wheat on parcel $D 21$, subsoil tillage in $50 \mathrm{~cm}$ depth.

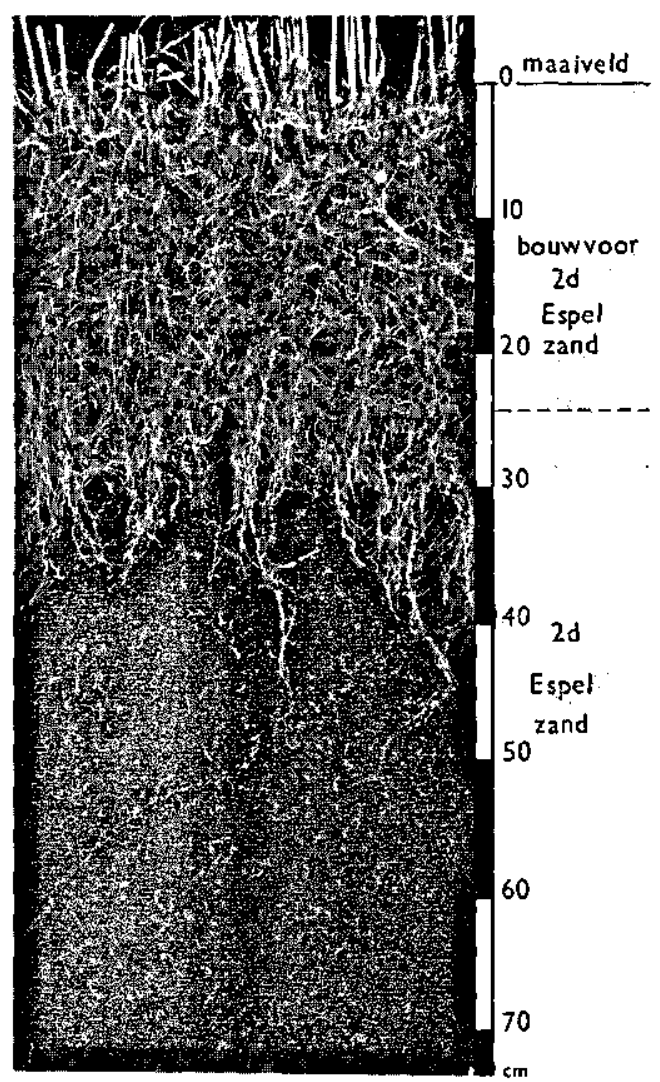

Fig. 61. Haver op kavel A 37, geen ondergrondbewerking, vgl. fig. 48 .

Oats on parcel $A$ 37, no subsoil tillage, see fig. 48. 